\title{
Vinícius Bassaneze
}

\section{Reprogramação de células mesenquimais de tecido adiposo em células-tronco pluripotentes por meio de proteína de fusão TAT}

Tese apresentada à Faculdade de Medicina da Universidade de São Paulo para obtenção do título de Doutor em Ciências

Programa de: Ciências Médicas

Área de concentração: Distúrbios Genéticos de Desenvolvimento e Metabolismo

Orientador: Prof. Dr. José Eduardo Krieger

São Paulo

2012 


\section{Vinícius Bassaneze}

\section{Reprogramação de células mesenquimais de tecido adiposo em células-tronco pluripotentes por meio de proteína de fusão TAT}

Tese apresentada à Faculdade de Medicina da Universidade de São Paulo para obtenção do título de Doutor em Ciências

Programa de: Ciências Médicas

Área de concentração: Distúrbios Genéticos de Desenvolvimento e Metabolismo

Orientador: Prof. Dr. José Eduardo Krieger

(Versão corrigida. Resolução CoPGr 5890, de 20 de dezembro de 2010 A versão original está disponível na Biblioteca FMUSP)

São Paulo

2012 
Dados Internacionais de Catalogação na Publicação (CIP)

Preparada pela Biblioteca da

Faculdade de Medicina da Universidade de São Paulo

Creprodução autorizada pelo autor

Bassaneze, Vinícius

Reprogramação de células mesenquimais de tecido adiposo em células-tronco pluripotentes por meio de proteína de fusão TAT / Vinícius Bassaneze. -- São Paulo, 2012.

Tese(doutorado)--Faculdade de Medicina da Universidade de São Paulo.

Programa de Ciências Médicas. Área de concentração: Distúrbios Genéticos de Desenvolvimento e Metabolismo.

Orientador: José Eduardo Krieger.

Descritores: 1.Genes TAT 2.TATkappa 3.Células iPS 4.Células-tronco pluripotentes induzidas 5.Reprogramação nuclear 6.Proteínas recombinantes de fusão

USP/FM/DBD-017/12 
Este trabalho foi desenvolvido no Laboratório de Genética e Cardiologia Molecular (LGCM) do Instituto do Coração (InCor) da Faculdade de Medicina da Universidade de São Paulo e recebeu apoio financeiro da Fundação de Amparo à Pesquisa do Estado de São Paulo (FAPESP), Conselho Nacional de Desenvolvimento Científico e Tecnológico (CNPq), Roche e Fundação Zerbini. 
Esta tese está de acordo com as seguintes normas, em vigor no momento desta publicação:

Referências: adaptado de International Committee of Medical Journals Editors (Vancouver)

Universidade de São Paulo. Faculdade de Medicina. Serviço de Biblioteca e Documentação. Guia de apresentação de dissertações, teses e monografias. Elaborado por Anneliese Carneiro da Cunha, Maria Julia de A. L. Freddi, Maria F. Crestana, Marinalva de Souza Aragão, Suely Campos Cardoso, Valéria Vilhena. 3a ed. São Paulo: Serviço de Biblioteca e Documentação; 2011.

Abreviaturas dos títulos dos periódicos de acordo com List of Journals Indexed in Index Medicus. 


\section{Dedicatória}

Dedicada ao meu avô, Adelino Polastre (in memorian), por ter me ensinado o verdadeiro significado da retidão de caráter. 


\section{Agradecimentos}

Essa tese de doutorado é uma somatória de esforços de um grande número de pessoas e certamente esse trabalho não teria sido concluído sem a participação de todos. Assim, é com grande entusiasmo e alegria que agradeço:

Ao meu orientador, Prof. Dr. José Eduardo Krieger, pela oportunidade, confiança e incentivo constante na execução desse trabalho. Acredito que a excelência que o laboratório vem atingindo é reflexo da maneira exemplar como a equipe é liderada. Agradeço também pela confiança na co-orientação dos meus primeiros alunos de iniciação científica.

À Dra. Ayumi Áurea Miyakawa Yamagushi, pela co-orientação que resultou nas inúmeras idéias que compõem esse trabalho e por todos os momentos que você me auxiliou das mais diversas maneiras. Agradeço muito também por oferecer a oportunidade e prover acolhimento na viagem de estágio de pesquisa ao Massachussets Institute of Technology - MIT.

Ao Dr. Chester Bittencourt Sacramento pela constante ajuda em momentos críticos do projeto, sempre me incentivando a continuar com essa pesquisa. Sua participação foi integral. Muito obrigado pela elaboração dos plasmídeos e execução dos experimentos de reprogramação em iPS de células humanas usando vírus.

Ao Prof. Dr. Bryan Strauss pelo auxílio na elaboração dos plasmídeos e às sempre interessantes conversas das quais resultaram soluções práticas para os problemas do dia a dia no laboratório.

À pesquisadora Dra. Elisabeth de Fátima Pires Augusto, do Instituto de Pesquisas Tecnológicas IPT/USP, pela disponibilidade em discutir formas 
alternativas de produção de proteínas recombinantes, que acabou resultando na presente colaboração, que caracteriza a interdisciplinariedade dessa tese.

À Prof . Dra. Deborah Schechtman, atualmente do Instituto de Química da USP (IQ/USP), pela discussão de idéias e compartilhamento de material, principalmente no início do projeto. Seus ensinamentos sobre o manejo de uma célula-tronco embrionária murina foram muito importantes para a posterior manipulação das células iPS murinas.

Ao pesquisador Dr. Keisuke Kaji, da Universidade de Edimburgo, Escócia, pelas primeiras e pacienciosas orientações de como identificar visualmente uma colônias iPS em processo de reprogramação, quando esteve em visita ao nosso laboratório.

Ao Prof. Dr. José Xavier Neto e ao Dr. Christian Merkel, pela primorosa execução dos experimentos de injeção de células que resultaram na obtenção do animal quimérico.

Aos Dr. Gustavo Gibin Duarte e Dr. Fábio Kamamoto, juntamente de suas respectivas equipes cirúrgicas - em especial para Tatiane Aparecida Bernardo Soares - pelo fornecimento do material de lipoaspiração e apoio durante o trabalho.

À Dra. Rosália Regina De Luca do ICB-USP, pelo auxílio nos experimentos que envolveram camundongos nude.

À Prof ${ }^{a}$. Dr. Neli Ortega, pelos ensinamentos e colaboração que resultou no novo sistema de classificação de colônias iPS utilizando lógica Fuzzy.

Ao Prof. Dr. Flávio Vieira Meireles e Fabiana Fernandes Bressan, da USP de Pirassununga, pelo empréstimo dos plasmídeos de lentivírus coloridos e outros reagentes e pelas valiosas conversas. 
Ao Dr. Tarsis Gesteira Ferreira e à Dra. Vivien Coulson-Thomas, da UNIFESP, pelo compartilhamento de reagentes e pelas produtivas discussões sobre como inibir a ligação da TAT às células usando Heparan Sulfato ou enzimas Heparinases.

Ao Pedro Luiz Andrade Scherholz e Gisela Sasso, ambos da Citologia da UNIFESP, pela análise de microscopia das lâminas e identificação de estruturas dos três folhetos embrionários nos teratomas das iPS.

À Daniela Bertolini Zanatta, pela dedicação na execução de praticamente todas as produções de lentivírus.

À Daniela Teixeira, da UNIFESP, pela realização dos experimentos de citometria de fluxo e de separação de células (cell sorting).

À Thais Girão da Silva pela ajuda nos experimentos de produção de TATGFP recombinante e nas extrações de células mesenquimais de tecido adiposo de camundongos.

Ao Rafael Dariolli, pela ajuda nos experimentos de Western Blotting e no ELISA das produtoras (transfecção transiente) e pelas constantes palavras de apoio ao desenvolvimento do projeto.

À Juliana Sanajotti Nakamuta, pela ajuda nas extrações de células mesenquimais de tecido adiposo de camundongos e pela revisão ortográfica da tese e à Gabriela Venturini, pelas incansáveis tentativas de realizar o sequenciamento das proteínas produzidas pelas células utilizando técnicas de espectrometria de massas.

À Samantha Omae Vieira por todas as extrações de células MEF, e auxílios nos aspectos práticos do projeto. 
À Nicole Milaré Garavello, por me ensinar minuciosamente como realizar os experimentos de hang'n'drop com as células iPS e mES.

Ao Diogo Biagi, pela revisão ortográfica na tese. Ao Arthur Nery pelas trocas de idéias e parceria para buscar e processar tecido adiposo. E aos novos alunos de iniciação científica Breno e Fábio, por todas as produtivas discussões.

Aos integrantes do grupo de Biologia Vascular, principalmente Luciene Christina Gastalho Campos e Valério Barauna. A ajuda de vocês foi sempre muito grande. Obrigado por todos esses anos de aprendizado mútuo e pelas inúmeras sugestões e auxílios sempre que precisei de vocês. Ao Valério, um agradecimento especial pelas longas, mas sempre divertidas discussões filosóficas sobre matemática e economia.

A toda equipe do Laboratório de Genética e Cardiologia Molecular InCor/FMUSP, inclusive o staff fixo do laboratório: Arruda, Dona Antônia, Janilton, Sileide, Silvana, Simone, Marcos, Márcio, Mariliza, Marina, Maúde, Noely e Renata, que tem participação ativa nas questões de ordem prática e burocrática do laboratório.

Aos meus parentes que sempre me apoiaram na carreira, especialmente à minha avó Santina e tias Ivanira e Ivone. E aos meus pais Cida e Marcos e meus irmãos Thiago e Bruno, por todo amor e carinho e pelos incondicionais incentivos para que eu completasse mais essa importante etapa em minha vida profissional.

À querida Raquel Brocchi, por ter me acompanhado nessa emocionante jornada com todo o carinho, compreensão e apoio.

E finalmente a todos meus amigos que sempre me estimularam a seguir na carreira científica (e não são poucos), mas especialmente ao Júlio Berger, Daniel 
Campos e Daniel Fioravanti, que num antiquíssimo período participaram ativamente da minha iniciação ao mundo da ciência. Gostaria de agradecer também aos grandes amigos Romeu Lopes, Fernanda Foschi, Luciene Scaravelli, João Vitor de Moraes, Karina Abe e Letícia Brandão e aos amigos e companheiros de república Alexandre, Luiz Paulo, Kleber, Matheus e Pedro, pelas constantes palavras de apoio e encorajamento e por nossa amizade que supera as circunstâncias.

A elaboração desse trabalho foi financiada pelas agências de fomento à pesquisa FAPESP (Fundação de Amparo à Pesquisa do Estado de São Paulo), pelo CNPq (Conselho Nacional de Desenvolvimento Científico e Tecnológico), Farmacêutica Roche e Fundação Zerbini. 


\section{Apresentação}

Este trabalho nasceu a partir de uma idéia inovadora, em uma época de efervescência da temática células-tronco pluripotentes induzidas, inclusive na mídia. Era um período que ainda não haviam alternativas demonstradas para a utilização de vetores virais.

Para maior clareza, primeiro são apresentados os dados sobre a geração das células iPS utilizando-se retrovírus e lentivírus que foram fundamentais para que se soubesse manipular essas células. Na sequência, seguem os experimentos de desenvolvimento do sistema de reprogramação com fatores nucleares utilizando proteínas de fusão. E finalmente são apresentadas as tentativas de utilização deste sistema para a reprogramação de células somática a partir de fontes diferentes em células-tronco pluripotentes.

Ainda, no Apêndice III são apresentados os dados do sistema utilizando lógica fuzzy feito para auxiliar na identificação de colônias verdadeiras de células iPS. 


\section{Epígrafe}

"La semplicità costituisce l'ultima sofisticazione”.

Leonardo di Ser Piero da Vinci

(1452-1519) 


\section{Sumário}

Índice de Tabelas................................................................................................................iii

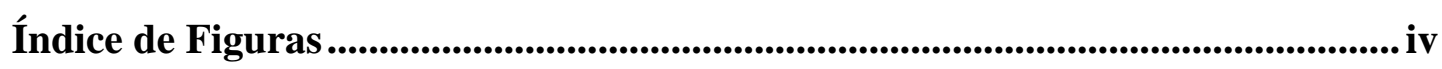

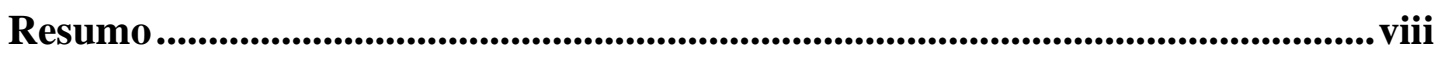

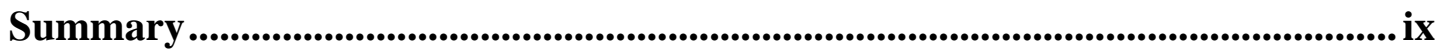

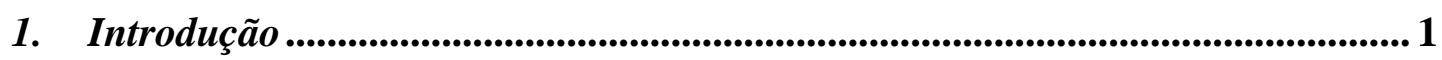

1.1. Terapia celular como alternativa terapêutica para doenças cardíacas de origem

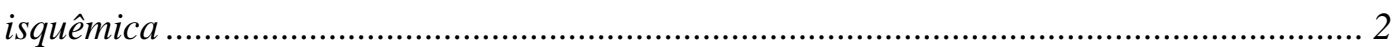

1.1.1. Injeção de cardiomiócitos neonatais e mioblastos esqueléticos ................................ 3

1.1.2. Injeção de células-tronco embrionárias …............................................................... 4

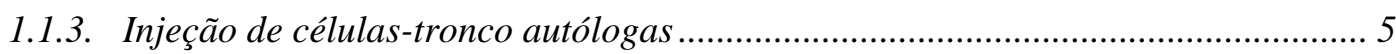

1.2. Reprogramação nuclear como solução para gerar células pluripotentes paciente-

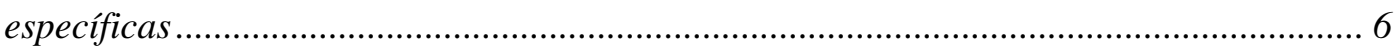

1.3. Proteínas contendo domínios de transdução de membrana como alternativa à

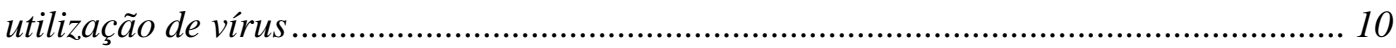

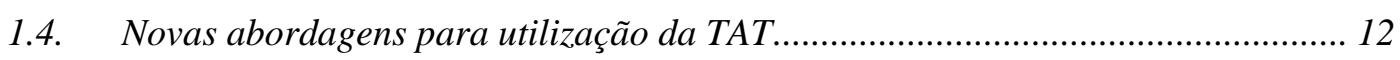

1.5. A proposta

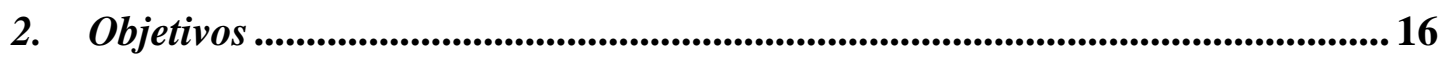

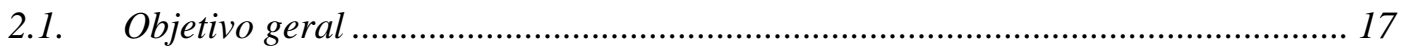

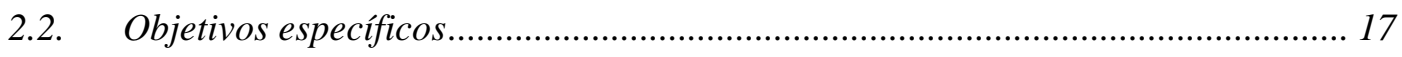

3. Materiais e Métodos ............................................................................ 18

3.1. Extração de células para cultura primária............................................................ 19

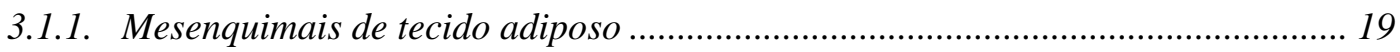

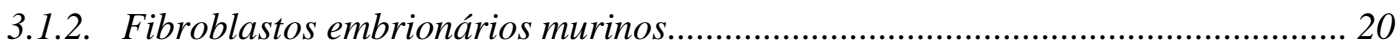

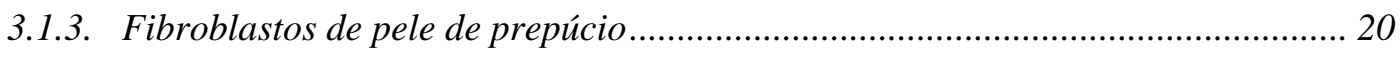

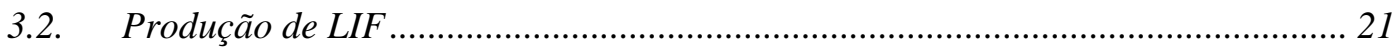

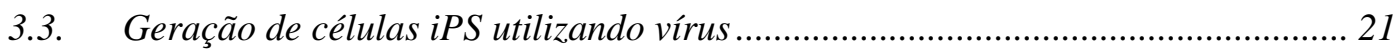

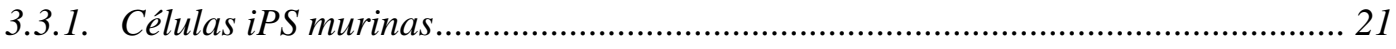


3.3.2. Células iPS humanas

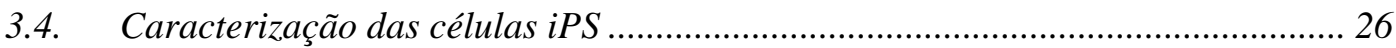

3.4.1. RT-PCR para genes marcadores de células-tronco pluripotentes......................... 26

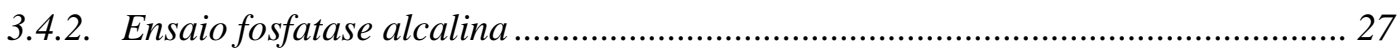

3.4.3. Formação de teratomas e análise histológica ..................................................... 27

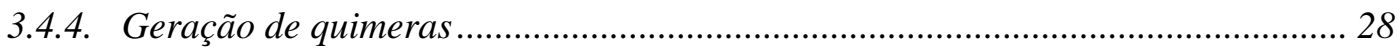

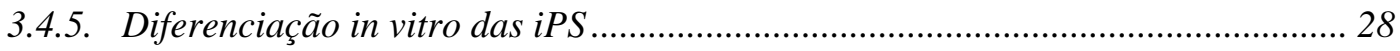

3.5. Preparação dos plasmídios contendo as sequências de interesse .......................... 29

3.6. Análises de Citometria e cell sorting ……........................................................... 31

3.7. Irradiação de células para efetuar parada de ciclo celular ................................... 32

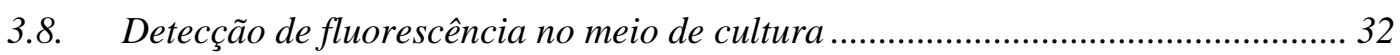

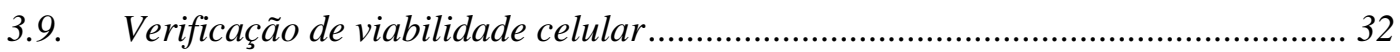

3.10. Verificação de concentração dos fatores de transcrição OCT, SOX, KLF e MYC

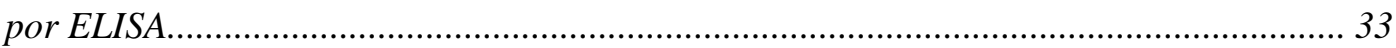

3.11. Geração das linhagens para produção de TAT-fator ............................................ 34

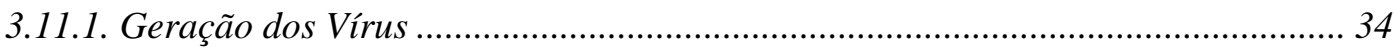

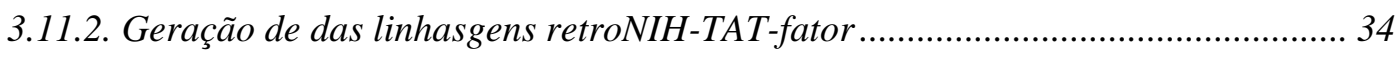

3.12. Geração das linhagens para produção de TATk-fator .......................................... 35

3.12.1. Geração de linhagens produtoras de fatores de transcrição usando pSecTAg2 ... 35

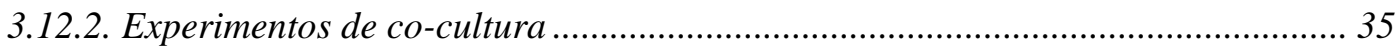

3.13. Adaptação das células produtoras ao cultivo sem soro bovino................................ 36

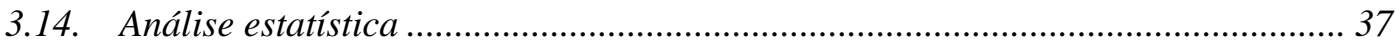

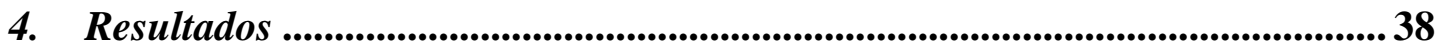

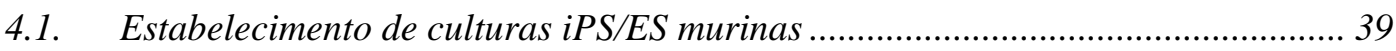

4.2. Obtenção de colônias iPS murinas com retrovírus................................................ 40

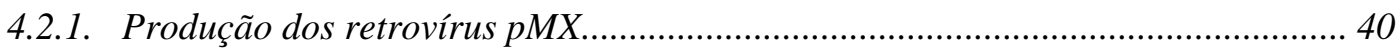

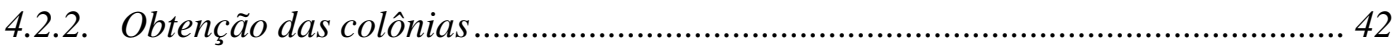

4.2.3. Verificação da pluripotência das colônias obtidas................................................. 47 


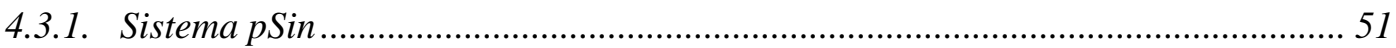

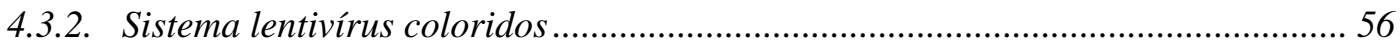

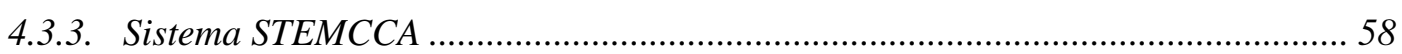

4.4. Desenvolvimento do sistema TAT-fator - Plasmídios pCL-TAT-fator-SN ............. 59

4.5. Determinação da escala de detecção de GFP fluorímetro...................................... 69

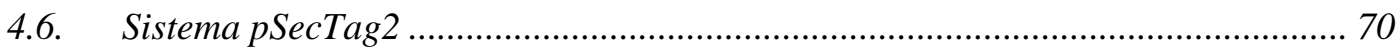

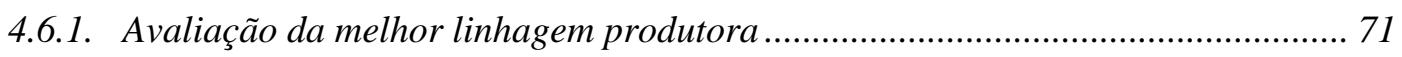

4.6.2. Investigação das limitações do sistema ................................................................. 79

4.7. Tentativas de reprogramação usando o sistema TATk ......................................... 83

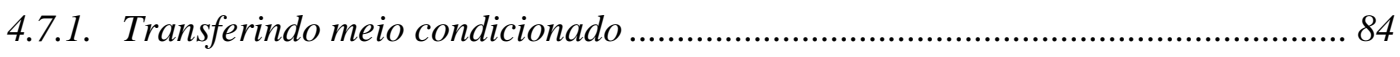

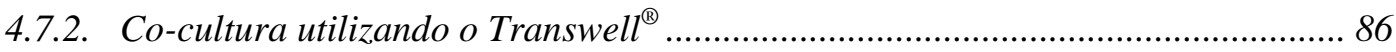

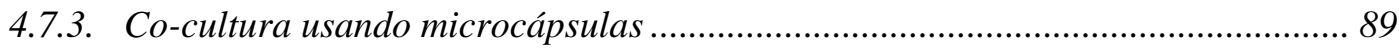

4.7.4. Aumentando a concentração das proteínas usando colunas Amicon .................... 92

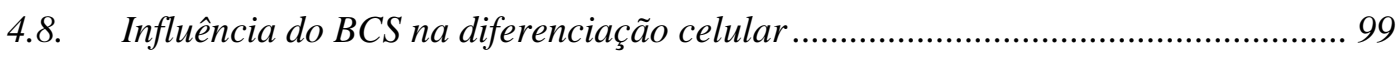

4.8.1. Adaptação das células produtoras à condição sem soro ..................................... 103

4.8.2. Produção de proteínas recombinantes em células animais usando transfecção transiente.

5. Discuss ão ................................................................................................................... 113

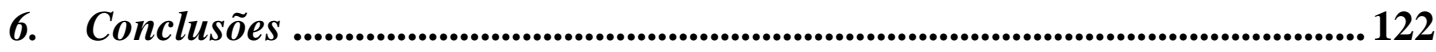

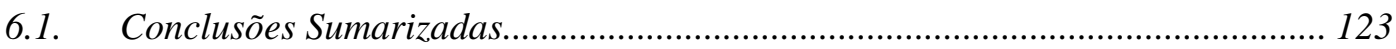

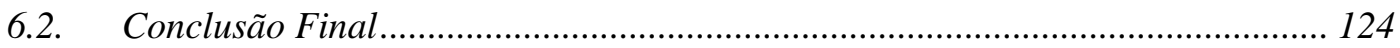

7. Perspectivas ....................................................................................................... 125

8. Anexos ........................................................................................................................ 127

Anexo A. Cópia do parecer de aprovação do projeto no Comitê de Ética para Análise de projetos de Pesquisa-CAPPesq. ............................................................. 128

Anexo B. Cópia do parecer de aprovação pelo CAPPesq da inclusão de subprojeto no processo 0949/9. 
9. Referências Bibliográficas ....................................................................130

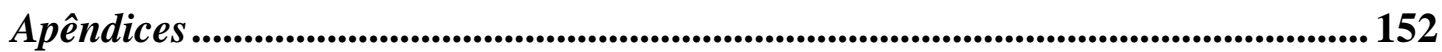




\section{Lista de Abreviações}

\begin{tabular}{|c|c|}
\hline ASC & - do inglês Adipose derived stem cell \\
\hline BCS & - do inglês Bovine calf serum \\
\hline BSA & - do inglês Bovine Serum Albumin \\
\hline CAPPesq & - Comissão de Ética para Análise de Projetos de Pesquisa \\
\hline cDNA & - DNA complementar \\
\hline CDM & - do inglês Chemically Defined Medium \\
\hline $\mathrm{CO}_{2}$ & - Dióxido de carbono \\
\hline Cols & - Colaboradores \\
\hline Ctrl & - Controle \\
\hline DMEM & - do inglês, Dulbecco's Modified Eagle Medium \\
\hline DMEM Low & - do inglês, Dulbecco's Modified Eagle Medium with Low Glucose \\
\hline DMSO & - Dimetilsulfóxido \\
\hline DNA & - do inglês, Deoxyribonucleic acid \\
\hline EDTA & - Ácido etilenodiamino tetra-acético \\
\hline ELISA & - do inglês, Enzyme Linked Immunosorbent Assay \\
\hline ES & - do inglês Embryonic Stem Cell \\
\hline FBS & - do inglês, Fetal Bovine Serum \\
\hline FLK-1 & - do inglês, Fetal Liver Kinase-1 \\
\hline FMUSP & - Faculdade de Medicina da Universidade de São Paulo \\
\hline hASC & - do inglês, Human ASC \\
\hline HEPES & - Ácido 4-(2-hidroxietil)-1-piperazineetanesulfonico \\
\hline hES & - do ingles Human Embryonic Stem Cell \\
\hline HFF & - do ingês Human Foreskin Fibroblasts \\
\hline HSP90 & - do inglês, Heat Shock Protein 90 \\
\hline KSR & - do inglês, Knockout Serum Replacer \\
\hline LIF & - do inglês, Leukemia Inhibitory Factor \\
\hline MCI & - massa celular interna \\
\hline MEF & - do inglês, Mouse Embrionic Fibroblasts \\
\hline MFI & - do inglês, Mean Fluorescence Intensity \\
\hline MSC & - do inglês, Mesenchymal Stem Cell \\
\hline MOI & - do inglês, Multiplicity of Infection \\
\hline Neg & - Negativo \\
\hline NLS & - do ingles, Nuclear Localization Sequences \\
\hline OSKM & - OCT3/4, SOX2, KLF e cMYC \\
\hline OSK & - ОСТ3/4, SOX2 e KLF \\
\hline OSNL & - OCT3/4, SOX2, Nanog e Lin28 \\
\hline pI & - ponto isoelétrico \\
\hline $\mathrm{P} / \mathrm{S}$ & - do inglês, Penicillin/Streptomycin \\
\hline $\mathrm{pb}$ & - Pares de base \\
\hline PBS & - do inglês, Phosphate Buffered Saline \\
\hline PFA & - Paraformaldeído \\
\hline $\mathrm{pH}$ & - Potencial hidrogeniônico \\
\hline $\mathrm{P} / \mathrm{S}$ & - antibióticos penicilina / estreptomicina \\
\hline PTD & - do inglês, Protein Transduction Domain \\
\hline rTAT-GFP & - proteína recombinante TAT-GFP produzida em bactérias \\
\hline RT-PCR & - do inglês, Reverse Transcription Polymerase Chain Reaction \\
\hline VPA & - do inglês, Valproic Acid \\
\hline
\end{tabular}


Lista de Símbolos

$\begin{array}{ll}\mathrm{g} & - \text { Gramas } \\ \mathrm{Gy} & - \text { Grays } \\ \mathrm{kDa} & - \text { Kilo daltons } \\ \mathrm{M} & - \text { Molar } \\ \mathrm{mg} & - \text { Miligrama } \\ \mathrm{mL} & - \text { Mililitro } \\ \mathrm{mM} & - \text { Milimolar } \\ \mathrm{ng} & - \text { Nanograma } \\ \mathrm{nm} & - \text { Nanômetro } \\ \mu \mathrm{g} & - \text { Micrograma } \\ \mu \mathrm{L} & - \text { Microlitro } \\ \mu \mathrm{M} & - \text { Micromolar }\end{array}$




\section{Índice de Tabelas}

Tabela 1: Oligonucleotídeos utilizados para verificação de reprogramação nuclear de camundongos. 27

Tabela 2: Oligonucleotídeos utilizados para construção dos plasmídeos.

Tabela 3: Determinação por ensaio de ELISA da quantidade de proteína TATк-fator que é secretada dependendo do tipo celular. 


\section{Índice de Figuras}

Figura 1: Linha do tempo das principais publicações relacionadas às células iPS até o período do início do projeto.

Figura 2: Representação esquemática das proteínas geradas pelos vetores de expressão pSecTag2 e pCL-X-SN. Essa organização é possível devido aos diferentes sítios de restrição de cada módulo.

Figura 3: Imagens representativas do aspecto em cultura das linhagens (A) E14TG2a e (B) R1-DsRED. 40

Figura 4: Density plots representativos da intensidade de fluorescência verde (GFP) versus tamanho celular (Forward Scatter, FSC) de células infectadas com retrovírus.

Figura 5: Density plots representativos da intensidade de fluorescência verde (GFP) versus tamanho celular (Forward Scatter, FSC) de células transfectadas para produzir vírus e infectadas de maneira a se avaliar o nível de transdução.

Figura 6: Imagem representativa das 38 colônias coletadas.

Figura 7: Imagens representativas da morfologia das colônias positivas iPS após a transferência. (Aumento 200x).

Figura 8: Células transfectadas com Lipofectamina apresentam menor variabilidade na produção retroviral.

Figura 9: Imagens representativas da verificação da presença da atividade de fosfatase alcalina

Figura 10: Caracterização das mIPS por imunofluorescência com microscópio confocal para SSEA1.

Figura 11: Verificação da formação de estruturas derivadas dos três folhetos embrionários em teratomas em animais Nude por coloração HE. Os aumentos utilizados estão indicados.

Figura 12: Geração de animal quimérico a partir de iPS 50 
Figura 13: Verificação do melhor empacotamento lentiviral para infecção de hASC $(\mathrm{N}=3)$

Figura 14: Imagem ilustrativas das colônias hiPS a partir de fibroblastos.

Figura 15: Formação de colônias hIPS depois de 18 dias desde a infecção. 54

Figura 16: Eficiência de infecção varia de acordo com lotes de produção. 55

Figura 17: hASC eficiência de infecção varia de acordo com lotes de produção..... 57

Figura 18: Imagens representativas das colônias de hiPS sob contraste de fase, após expansão.

Figura 19: RT-PCR de linhagens NIH-3T3 infectadas com retrovírus para expressar TAT-GFP, TAT-SOX.

Figura 20: Verificação da expressão de GFP por células transduzidas com retrovírus pCL-TAT-GFP-SN.

Figura 21: Verificação da hipótese de (A) degradação do proteossoma da proteína TAT-GFP e (B) do efeito da quantidade de DNA na eficiência de produção de retrovírus pCL-TAT-GFP-SN

Figura 22: Seleção manual de células verdes para obtenção de colônia $100 \%$ verde.

Figura 23: Density plots representativos da intensidade de fluorescência verde (GFP) versus tamanho celular (Forward Scatter, FSC) de células receptoras e produtoras de TAT-GFP em sistema de co-cultura transwell após $24 \mathrm{~h}$ em contato.. 65

Figura 24: Perfil na citometria de fluxo após tratamento com TAT-GFP recombinante.

Figura 25: Tratamento de células NIH-3T3 receptoras com meio condicionado..... 68

Figura 26: Curva padrão de rTAT-GFP. .70

Figura 27: Rastreamento da eficiência de transfecção do plasmídeo pSecTag2TATк-GFP em seis diferentes linhagens de células após $48 \mathrm{~h}$.

Figura 28: Detecção de TATк-GFP no sobrenadante no fluorímetro após 24h....... 74 
Figura 29: Verificação da influência do tempo (24, 48 e 96h) no perfil de secreção

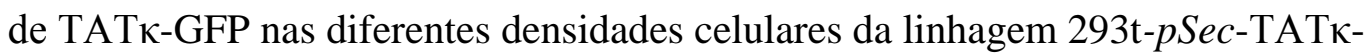
GFP.

Figura 30: Rastreamento do maior potencial de secreção de TATк-GFP entre os seis tipos celulares testados 76

Figura 31: Verificação da expressão gênica de TATא-fatores por RT-PCR. .79

Figura 32: Cell sorting da linhagem 293t-pSec-TATк-GFP. 80

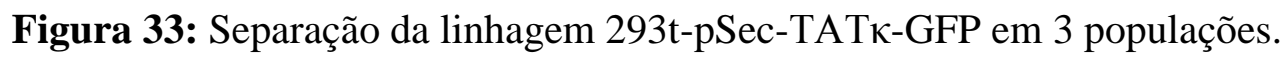
81

Figura 34: Comparação de produção de TAT-GFP e TATк-GFP nas células 293t. 83

Figura 35: Imagens representativas de uma placa de seis poços com MEF e HFF tratado com meio condicionado derivado de $\mathrm{CHO}$ e 293A-TAT $\kappa$-fatores.

Figura 36: Imagem representativa da acidificação do meio de célula em transwell de $1 \mu \mathrm{m}\left(10 \times 10^{4} \mathrm{cels} / \mathrm{cm}^{2}, 24\right.$ horas $)$ por células de produção.

Figura 37: Co-cultura utilizando transwell de $3 \mu \mathrm{m}$ das diferentes populações de células 293t-pSec-TATк-GFP separadas por citometria de fluxo.

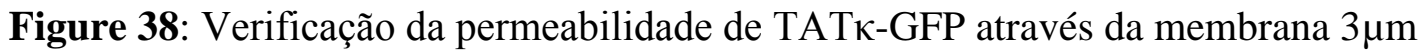
do sistema transwell em função do tempo.

Figura 39: Tratamento com radiação gama em células na linhagem 293A-TATкOCT induz morte celular.

Figura 40: TATк-GFP concentrada é capaz de entrar nas células e ser detectável por citometria de fluxo.

Figura 41: Tentativas com meio de cultura concentrado para reprogramar células ao estado pluripotente.

Figura 42: Verificação do funcionamento das TATк-proteínas independentemente.

Figura 43: Células iPS sem camada feeder se diferenciam quando cultivadas na presença de $15 \%$ BCS, após $24 \mathrm{~h}$ 
Figura 44: A presença de BCS no meio condicionado persiste mesmo após ciclos de lavagem com "PBS+". 101

Figura 45: Associação entre BCS no meio condicionado concentrado e a quantidade de proteínas no BCS.

Figura 46: Adaptação das linhagens produtoras 293t e CHO aos meio de cultura CDM-CHO.

Figura 47: Silenciamento gênico das linhagens produtoras 293t e CHO adaptadas ao cultivo em CDM-CHO.

Figura 48: Perfil de produção de TATк-GFP por até sete dias por células 293t transfectadas com lipofectamina de maneira transiente.

Figura 49: Analise da expressão de proteína por Western Blotting de (A) TATкOCT e (B) TATк-MYC no meio de cultura nos sete dias de produção das células $293 \mathrm{t}$ transfectadas de maneira transiente. Chama atenção também a extensa marcação inespecífica dos anticorpos.

Figura 50: Analise da presença de proteínas contaminantes derivadas do BCS no meio de cultura condicionado.

Figura 51: Figura representativa das células MEF 12 dias após o inicio do tratamento com proteínas. (A) Ctrl neg e (B) células infectadas com retrovírus pMX para expressar OSM e tratadas com a proteína recombinante KLF.

Figura 52: Visão geral dos principais trabalhos publicados sobre métodos para reprogramação celular durante o período do projeto. 


\section{Resumo}

\section{Bassaneze, V. Reprogramação de Células Mesenquimais de Tecido Adiposo em}

\section{Células-Tronco Pluripotentes por Meio de Proteína de Fusão TAT [tese]. São Paulo:}

Faculdade de Medicina, Universidade de São Paulo; 2012.

Os vírus são eficazes na transferência de genes em células devido aos seus mecanismos especializados. No entanto, vírus como veículos de entrega de genes podem acarretar em problemas, particularmente quando proposto para reprogramar células somáticas em células-tronco pluripotentes induzidas (iPS) visando utilização terapêutica. No presente estudo, procurou-se desenvolver um sistema alternativo para entregar diretamente proteínas nucleares (Oct4, Sox2, KLF4, e c-Myc)

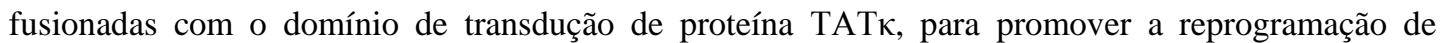
fibroblastos embrionários de camundongos (MEF) ou células mesenquimais derivadas de tecido adiposo humano (hASC) em células iPS. Primeiramente o PTD TAT ou TATк- foi fundido a proteína verde fluorescente (GFP) como modelo para prova de princípio e padronização detalhada. Inesperadamente, TAT-GFP produzido e secretado pelas células NIH-3T3 produtora não foi capaz de ser detectado no meio de cultura por verificação quantitativa fluorimétrica, nem foi capaz de ser detectada em células-alvo, por citometria de fluxo, depois de co-cultura em transwells. Essa observação pode ser explicada por: (1) ineficiência desse tipo de célula em secretar proteínas e (2) falta de resistência à clivagem por endoproteases furinas. Para contornar esses fatores limitantes usouse citometria de fluxo para avaliar as melhores condições para a transfecção por seis diferentes tipos de células (CHO, NIH-3T3, HT1080, HEK-293A, HEK-293t e COS-7) com TATк (modificada para ser resistente à furinas) fundido a GFP. Células 293t-TATк-GFP exibiram a maior eficiência de transfecção e também de secreção. O mesmo pôde ser observado para as seis linhagens celulares

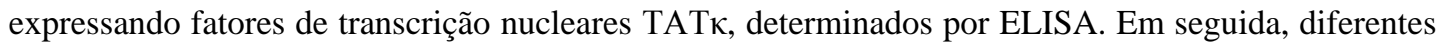
estratégias de entrega foram testadas. A primeira foi baseada na co-cultura de uma mistura de células produtoras com MEF ou hASC. No entanto, não foi possível observar a reprogramação devido à morte celular. A segunda foi baseada na concentração de meio condicionado de cultura de células por centrifugação usando colunas Amicon, trocando o meio a cada 24h, em quatro ciclos. No entanto, apesar da presença de algumas colônias após 20-30 dias, nenhuma colônia verdadeira iPS foi obtida. $\mathrm{Na}$ sequência, as células foram tratadas com cada proteína de forma independente, e as demais foram substituídas pelo retrovírus correspondente, trocando meio a cada $72 \mathrm{~h}$, em quatro ciclos. Essa estratégia, apesar de permitir verificar a função de cada proteína, também não resultou em reprogramação. Este achado pode ser explicado pela diferenciação celular induzida por BCS, que também é concentrado no processo. Assim, passou-se a adaptação de "células produtoras" em condições de cultura livre de soro, para enriquecer a produção dos fatores nucleares individuais, necessários para a reprogramação. A otimização sistematizada deste processo está sendo realizada em parceria com o IPT e deve resultar em quantidades de proteína de fusão suficientes para o teste final da hipótese proposta. Em conjunto, são apresentados os dados da geração de linhagens celulares expressando estavelmente os vários fatores de transcrição e estratégias para melhorar a eficiência necessária para a produção iPS. Esta nova estratégia garante uma produção eficiente de TATк fundida a fatores nucleares de reprogramação e sua eficácia para promover a reprogramação de células somáticas de maneira livre de vírus merece ser investigado futuramente.

Descritores: Genes TAT; TATкарpa; células iPS; células-tronco pluripotentes induzidas, reprogramação nuclear, proteínas recombinantes de fusão. 


\section{Summary}

Bassaneze, V. Nuclear reprogramming of adipose-tissue mesenchymal stem cells into pluripotent stem cells using TAT fusion protein [thesis]. São Paulo: "Faculdade de Medicina, Universidade de São Paulo"; 2012.

Viruses are effective at transferring genes into cells by its specialized mechanisms. However, viruses as gene delivery vehicles entail problems, particularly when proposed to reprogram somatic cells into induced pluripotent stem cells (iPS) for therapeutic uses. In the present study, we aimed to develop an alternative system for directly delivering nuclear proteins (Oct4, Sox2, Klf4, and c-Myc) fused with TATא protein transduction domain to promote reprogramming of mouse embryonic fibroblasts (MEF) or human adipose tissue derived mesenchymal cells (hASC) into iPS cells. First TAT- or TATк- PTD was fused to green fluorescent protein (GFP) as a proof of principle model and for detailed standardization. Unexpectedly, TAT-GFP produced and secreted by NIH-3T3 producer cells was not detected in the culture medium by quantitative fluorimetric verification, nor detected on target cells, by flow cytometry, after being co-cultured using transwells. This observation maybe explained by: (1) inefficiency of this cell type to be transfected and to secrete proteins and (2) lack of resistance to furin endoproteases cleavage on Golgi of TAT sequence. To circumvent these limiting factors we used flow cytometer to assess the best conditions for transfection in six different cell types (CHO, NIH-3T3, HT1080, HEK-293A, HEK-293t and COS-7) with TAT $\kappa$ - (a modified PTD to be resistant to furin endoproteases) fused to GFP. 293t-TATк-GFP cells displayed the highest transfection efficiency and secretion levels. The same could be observed for the six cell lineages expressing TAT $\kappa$ - nuclear transcription factors, determined by ELISA.Next, different delivery strategies were tested for TATאnuclear transcription factor system. Co-culturing a mix of producer cells with MEF or hASC resulted in not reprogramming and this was associated with cell death. The second was based on the use of microconcentrated conditioned cell culture medium, changed every $24 \mathrm{~h}$, in four cycles. However, despite the presence of some emerging colonies after 20-30 days, no true iPS colonies were obtained. Then, cells were treated with each protein independently, and the others were replaced by the corresponding retrovirus, changing cell medium every $72 \mathrm{~h}$, in four cycles. We verified the reprogramming potential of each protein, but no true colonies were obtained.One possibility for this finding is that BCS is also concentrated by centrifugation and may induce cell differentiation. To circumvent these problems, we have started the adaptation of "producer cells" in a serum-free culture condition to enrich the production of the individual factors required for reprogramming. This optimization process is taking place in collaboration with the IPT and shall result in large amounts of the fusion protein to finally test the proposed hypothesis. Altogether, we presented the generation of several cell lines stably expressing the transcription factors and strategies to improve the efficiency required for iPS production. This novel strategy guarantees efficient production of TATK-fused reprogramming nuclear factors and its efficacy to promote somatic cells reprogramming in a virus-free manner deserves to be further investigated.

Descriptors: Genes, TAT; TATкарра; iPS cells; induced pluripotent stem cells; nuclear reprogramming; recombinant fusion protein 


\section{Introdução}




\subsection{Terapia celular como alternativa terapêutica para doenças cardíacas de origem isquêmica}

As doenças isquêmicas do coração correspondem a uma parcela significativa das causas de mortalidade no mundo e nos países em desenvolvimento ${ }^{1}$ como o Brasil $^{2}$. Sua fisiopatologia é decorrente de lesões obstrutivas que impedem a chegada de sangue ao músculo cardíaco, levando à morte de células, inclusive cardiomiócitos, e consequentemente à deterioração progressiva da função do órgão. O tamanho da área afetada é diretamente proporcional ao grau de severidade da doença e, dependendo do tamanho da área afetada, torna-o incompatível com a sua finalidade de prover sangue aos tecidos. Em estágios avançados representa uma das doenças mais devastadoras. Para 30 dias, um e cinco anos após o início das hospitalizações, observam-se respectivamente, taxas de mortalidade de $10 \%, 22 \%$ e $42 \%^{3}$.

Num esforço para prevenir a incidência e reparar os efeitos deletérios da doença, inúmeras estratégias medicamentosas e cirúrgicas têm sido desenvolvidas nos últimos 50 anos, as quais representam um dos melhores exemplos de avanços da medicina moderna, com grande impacto para os cofres dos sistemas de saúde.

A despeito de tal progresso, sabe-se que quando há comprometimento de grande área do músculo cardíaco, a região afetada não é repovoada por novos cardiomiócitos. Ela é substituída gradualmente por um tecido fibroso não contrátil, que compromete a função contrátil do tecido viável não-afetado. Isso estimula a adaptação generalizada do órgão e que, em longo prazo, evolui para a insuficiência cardíaca. Muitas vezes a única solução para casos graves é o transplante cardíaco, limitado à disponibilidade de doadores e com complicações relacionadas à rejeição. A possibilidade de substituir as células perdidas durante o evento isquêmico por 
outras igualmente competentes em termos funcionais representa a principal motivação dos estudos que propõem o uso de células exógenas como terapia.

Por muitos anos acreditou-se que os cardiomiócitos, assim como algumas células do sistema nervoso central, não disponham de qualquer capacidade proliferativa com a chegada da vida adulta. Mais recentemente, ensaios de pulsechase com os análogos da timidina ${ }^{4}$, de rastreamento de linhagem de células ${ }^{5,6}$, e datação de ${ }^{14} \mathrm{C}$ ao nascimento ${ }^{7}$ têm oferecido evidências fortes de que há renovação de cardiomiócitos ao longo da vida de um indivíduo e, principalmente, quando há lesão ao músculo cardíaco por isquemia ou sobrecarga pressórica. Nos últimos anos tem se procurado desenvolver alternativas terapêuticas para promover a regeneração do tecido cardíaco danificado pela isquemia. Uma alternativa experimental que tem tido bastante destaque é a terapia celular ${ }^{8}$, que objetiva transplantar células no tecido que se pretende recuperar. Esse tipo de estratégia é análogo ao que é realizado há muitos anos com sucesso para tratamento de uma série de doenças hematológicas 9 .

\subsubsection{Injeção de cardiomiócitos neonatais e mioblastos esqueléticos}

Os mais variados tipos de células já foram testados em modelo animal de doença isquêmica cardíaca. Os primeiros ensaios foram com os próprios cardiomiócitos terminalmente diferenciados, derivados de animal doador adulto ${ }^{10,11}$ ou fetal ${ }^{12}$; esses últimos ainda mantendo algum grau de capacidade proliferativa. Apesar de resultados favoráveis em algumas circunstâncias ${ }^{13}$, a grande limitação desta abordagem para aplicação clínica está na disponibilidade de células em número suficiente para o reparo e na garantia que as células transplantadas serão incorporadas ao "sincício funcional cardíaco" do hospedeiro. A limitação em 
expandí-las in vitro e a tarefa de substituir dezenas de bilhões de cardiomiócitos perdidos no infarto representam desafios não solucionados.

Outra alternativa testada foi transplantar mioblastos esqueléticos ${ }^{14}$, que são fenotipicamente próximos de células precursoras de cardiomiócitos e naturalmente capazes de proliferar e regenerar o músculo esquelético. Inicialmente parecia ser interessante e seguro (por ser autólogo, ou seja, derivada do próprio indivíduo que irá recebê-la) para regeneração cardíaca. Contudo, ensaios in vivo demonstraram que apesar de se observar algum benefício à contratilidade, não se obtiveram resultados de regeneração convincentes ${ }^{15}$. E à medida que o número de células transplantadas aumentou para a ordem de $10^{9}$, observaram-se complicações como geração de focos arritmogênicos e falha na integração das células ao músculo cardíaco pré-existente ${ }^{16}$.

\subsubsection{Injeção de células-tronco embrionárias}

Em função dessas limitações, passou-se a buscar outros tipos de células que tivessem capacidade proliferativa e de se diferenciar em cardiomiócitos funcionais e integrativos das mais variadas origens. Células-tronco embrionárias (ES, Embryonic Stem cells) pluripotentes surgem como interessantes candidatas, inclusive porque tinha ocorrido há pouco a derivação a partir de células humanas ${ }^{17}$. Embora tal fonte de células pareça mais promissora, tiveram algum atraso devido às considerações éticas e legais a seu respeito, que ainda não estavam solucionadas. Além disso, essas células possuem um inerente elevado grau de risco de rejeição e geração de teratomas quando transplantadas. Assim, as células-tronco multipotentes, que já vinham sendo estudadas há vários anos no contexto do transplante de medula óssea, acabaram sendo as principais candidatas devido à facilidade de obtenção e por serem autólogas. 


\subsubsection{Injeção de células-tronco autólogas}

Nos últimos 10 anos, inúmeros experimentos em modelos animais de cardipatias ${ }^{18,19}$ demonstraram benefícios ao coração com o transplante de célulastronco autólogas das mais variadas origens - como as células hematopoiéticas e mesenquimais de medula óssea e do tecido adiposo ${ }^{20}$. Infelizmente, os estudos clínicos em humanos não foram tão consistentes ${ }^{21}$. Isso pode ser atribuído, pelo menos em parte, a questões importantes que compreendem desde a retenção das células transplantadas no tecido cardíaco que pode variar de acordo com a metodologia de administração empregada, até ao efeito vinculado à diferenciação dessas células. Especialmente em humanos, isso ainda não foi bem investigado e compromete a avaliação da eficácia do procedimento ${ }^{22}$. O grande número de resultados acumulados em estudos pré-clínicos sugere que, nas vezes em que houve melhora da função cardíaca, isto não se deveu ao fenômeno de diferenciação (transdiferenciação) celular ${ }^{23}$. Diferentemente das conclusões iniciais ${ }^{24,25}$, hoje se acredita que os efeitos benéficos do simples transplante das células-tronco como as mesenquimais podem ser explicados por interessantes propriedades como modulação da inflamação ${ }^{26}$, produção de uma série de moléculas anti-apoptóticas ${ }^{27}$, cardioprotetoras ${ }^{28}$ e principalmente angiogênicas ${ }^{29,30}$ - processos esses acontecendo no microambiente onde as células mesenquimais são inseridas. A formação de novos vasos é bastante importante para impedir a progressão da lesão e esse tipo celular continua interessante para essas aplicações. Ensaios clínicos de fase III em humanos vêm sendo feitos com as células mesenquimais para estabelecer protocolos padrão para tratamento do infarto do miocárdio ${ }^{31}$, entretanto sem a expectativa de repor os cardiomiócitos perdidos com essa abordagem. A geração de uma grande quantidade 
de cardiomiócitos novos, que também seria necessária, não acontece in vivo com essas células. O que se observa comumente é fusão celular ${ }^{32}$. Apesar disso, evidências in vitro usando 5 -azacitidina ${ }^{33}$, dentre outras abordagens ${ }^{34}$, continuam até hoje dando suporte à expectativa de que essas células tenham algum potencial de gerar cardiomiócitos em condições específicas, e isso continua sob investigação.

Ou seja, ainda que as células mesenquimais multipotentes não sejam ideais, apresentam características interessantes, principalmente do ponto de vista da estimulação da formação de novos vasos. Por outro lado, a obtenção de células com um verdadeiro potencial de diferenciação em cardiomiócitos e imunocompatíveis continua sendo bastante interessantes para a aplicação na terapia celular e na engenharia de tecidos.

\subsection{Reprogramação nuclear como solução para gerar células pluripotentes paciente-específicas}

Ao longo de toda extensão de vida de um organismo multicelular, as células passam por um contínuo e crescente processo de diferenciação, de forma a terem a possibilidade de executarem tarefas mais específicas ${ }^{35}$. Postula-se que possam ser identificados de 407 a 873 tipos celulares distintos num humano adulto normal e saudável ${ }^{36}$. Já nas primeiras etapas de clivagem dos blastômeros, observa-se a geração das células pluripotentes da massa celular interna (MCI; que vão dar origem ao corpo do embrião), e outras para a formação do trofoectoderma, que vão dar origem à placenta ${ }^{37}$.

Células pluripotentes são definidas como aquelas capazes de se diferenciar em todas as células de um embrião, contudo, sem ter a capacidade de autoorganização necessária para gerá-lo por completo ${ }^{38}$. In vivo, essa peculiaridade só 
pode ser encontrada nas transientes células da MCI dos blastocistos. As células que compõem o epiblasto da MCI podem ser extraídas utilizando-se um processo bastante minucioso e, quando essas obtidas, podem ser mantidas em cultura ex vivo, gerando uma linhagem celular. Nessas condições elas são denominadas ES, cuja pluripotência é conservada pela adição de fatores que promovem sua proliferação com ausência de diferenciação ${ }^{38,} 39$. Particularmente, essas células são muito interessantes para futuras aplicações na terapia celular devido à capacidade de gerar cardiomiócitos genuínos in vitro.

A diferenciação de células pluripotentes em linhagens específicas compreende um vasto número de alterações bioquímicas e epigenéticas que ainda não estão plenamente compreendidas ${ }^{40,41}$. Essas influenciam o destino em longo prazo de cada célula e seus futuros progenitores. Ainda que se observe rotineiramente a reversão do fenótipo dos espermatozoides (células diferenciadas) após sua fusão (ao oócito) e subsequente reprogramação nuclear em uma célula indiferenciada totipotente (célula ovo), por muito tempo se manteve incerta a possibilidade de se recapitular esse processo artificialmente. O sucesso dos experimentos de clonagem de mamíferos por meio da introdução do núcleo de células somáticas adultas em oócitos foi uma das primeiras demonstrações claras de que o citoplasma de células primordiais poderia conter os elementos suficientes para reprogramar o núcleo de células somáticas ${ }^{42}$. Além disso, a criação de híbridos por fusão celular de células somáticas de várias origens com ES demonstram o sucesso na reprogramação de células somáticas de humanos com re-expressão de marcadores de pluripotência ${ }^{43}, 44$. Entretanto, os híbridos celulares resultantes conteriam inevitavelmente dois genomas completos, o que limitaria qualquer abordagem que se 
pensasse para o uso na prática clínica. A enucleação das células ES antes da fusão seria uma possível solução para esse problema. Entretanto, a viabilidade desse processo é questionável, pois ao ser realizada a enucleação, elimina-se a habilidade do citoplasma das ES de reativar a expressão de marcadores de pluripotência em híbridos com células somáticas ${ }^{44}$. Outra solução seria a remoção de cromossomos, contudo é inviável para o completo cariótipo excedente ${ }^{45}$. Outras abordagens testadas foram a exposição direta de células somáticas a extratos de oócitos de Xenopus $s p^{46}$, de células germinativas embrionárias ${ }^{47}$, ou até mesmo de células ES 48. Essas se apresentaram com sucesso parcial na reversão de alguns aspectos da diferenciação celular, principalmente de HEK-293t, relatando-se a re-expressão do marcador OCT3/4. Foi demonstrado também o potencial de diferenciação das HEK$293 t$ reprogramadas em outras linhagens mediante estímulos específicos ${ }^{48}$.

Mais recentemente a reprogramação nuclear de células foi conseguida com bastante eficiência e de maneira inovadora. Takahashi e cols ${ }^{49}$, liderado pelo Prof. Shinya Yamanaka, promoveu a transdução viral de uma série de 24 fatores de transcrição nuclear que sabidamente estavam fortemente expressos em células tronco embrionárias, e efetuou a seleção com antibiótico para a expressão do fator Fbox15. Após alguns dias foi possível constatar que era possível reprogramar células somáticas de camundongo, dando origem às denominadas células-tronco pluripotentes induzidas (iPS, induced Pluripotent Stem). Ainda, utilizando uma estratégia na qual se realizou uma combinação seriada dos diferentes fatores e se removeu da lista aqueles que não ofereciam incremento na quantidade de colônias geradas, descobriram que com a utilização de apenas quatro dos 24 fatores de transcrição (Oct3/4, Sox2, Klf4 e c-Myc) era possível obter as células pluripotentes. 
Essas células exibem morfologia, padrão de marcadores e propriedades de proliferação similares às ES. Além disso, elas não apresentam senescência celular após longo tempo em cultura, ao contrário dos fibroblastos que as deram origem. Cerca de um ano após essa publicação, uma série de novos trabalhos utilizando os mesmo genes ${ }^{50}$, ou abordagens muito semelhantes ${ }^{51,52}$, reproduziram os experimentos iniciais. As semelhanças das células iPS às ES ficou ainda maior devido à demonstração da capacidade de geração de camundongos quiméricos férteis pela introdução dessas células em blastocistos ${ }^{52}$. E, finalmente, conseguiu-se gerar iPS a partir de fibroblastos humanos ${ }^{53,54}$ inclusive utilizando-se outra combinação de fatores de transcrição a partir de OCT, SOX, Nanog e Lin28 ${ }^{55}$. Jaenish e cols ${ }^{52}$ utilizando Oct3/4 ou Nanog como fator de seleção, conseguiram gerar iPS capazes de formar teratomas quando injetadas em animais nude, os quais continham células diferenciadas das três linhagens germinativas, fato que aumentou ainda mais a similaridade dos níveis e do padrão de expressão gênica de marcadores com as ES.

Entretanto, nesses animais, por exemplo, é frequente a formação de tumores de pescoço, devido à reativação da expressão do transgene c-Myc na fase adulta ${ }^{50}$. $\mathrm{Na}$ tentativa de solucionar este problema, iPS de humanos foram geradas sem a utilização de c-Myc ${ }^{56}$, ou com a utilização de outros genes ${ }^{57}$ ou ainda de microRNAs (miRNA) que substituem o myc junto do vírus contendo os outros 3 genes ${ }^{58}$. Porém, a utilização de sistema de vetores virais definitivos, ainda tornava qualquer possibilidade de aplicação dessas células em humanos impraticável. Além do risco de desenvolvimento de tumores por ativação de genes endógenos devido à mutagênese insercional, os vírus, por serem estáveis, não são eliminados do genoma com o tempo. Como alternativa pôde-se pensar na utilização de coquetéis dos fatores 
de transcrição, bem como a utilização de sistemas transientes de expressão ou de entrega de proteínas. Hoje já são conhecidas outras formas de se promover a reprogramação nuclear, mas na época do início desse trabalho, não existiam alternativas publicadas às estratégias que utilizam vírus.

\subsection{Proteínas contendo domínios de transdução de membrana como alternativa à utilização de vírus}

Existem diversas maneiras diferentes para se efetuar a entrega intracelular de proteínas de interesse ${ }^{59}$. Um sistema bastante interessante que poderia substituir os sistemas virais seria a utilização de pequenos peptídeos que permitem a passagem de macromoléculas através da membrana plasmática de maneira eficiente, inclusive in vivo ${ }^{60}$. Essa abordagem se fundamentou inicialmente na expressão de proteínas de interesse fundidas a esses peptídeos, utilizando-se sistemas de expressão em bactérias, principalmente Escherichia coli. Na sequência, dependendo do objetivo proposto, essas proteínas (normalmente purificadas) são colocadas em contato com as células in vitro ${ }^{61}$, perfundidas ou injetadas diretamente no tecido de interesse do animal $^{60}$.

Existem descritos diversos desses peptídeos que conseguem exercer essa função e eles são denominados domínios de transdução de proteínas (PTD, Protein Transduction Domain). Os mais estudados, dentre outros de origem sintética, são o peptídeo VP22 derivado do vírus da Herpes, o Anp, derivado de Drosophila melanogaster, e o TAT, derivado do vírus HIV-1 ${ }^{62}$ (cuja sequencia de aminoácidos é YGRKKRRQRRR). Eles têm chamado bastante atenção devido à alta eficiência de transdução e baixa toxicidade, além de conseguirem carrear proteínas até mesmo ao núcleo das células ${ }^{63}$. Todos apresentam basicamente as mesmas características 
físico-químicas (abundância de aminoácidos catiônicos básicos, dando carga positiva ao peptídeo em $\mathrm{pH}$ neutro e $\mathrm{pI}$ de aproximadamente 12) e provavelmente o mesmo mecanismo de ação, ainda que este último não esteja totalmente esclarecido ${ }^{64}$. Os resultados de estudos in vitro sugerem que os PTDs entram nas células via endocitose dependente de energia, de maneira concentração-dependente, trabalhando-se em escala de nano a micromolar e atingindo níveis intracelulares detectáveis em questão de poucos minutos. Em particular, estudos usando inibidores, tais como metil- $\beta$-ciclodextrina ${ }^{65}$ (para remover o colesterol da membrana) ou amiloride ${ }^{64,66}$ (inibidor do trocador $\mathrm{Na}^{+} / \mathrm{H}^{+}$) indicam que PTDs são tomados via macropinocitose dependente de lipid rafts, após forte interação iônica dos resíduos de aminoácidos da PTD com os constituintes da membrana plasmática. Uma vez dentro das células, as proteínas de fusão saem das vesículas lipídicas por transporte retrógrado, atingindo o citoplasma ${ }^{67}$. E se estiverem desnaturadas, proteínas chaperonas intracelulares (tais como HSP 90) se encarregam de prover a conformação adequada ${ }^{68}$. Em seguida, quando se tratam de proteínas nucleares, suas sequencias de localização nuclear (NLS, do inglês Nuclear Localization Sequences) podem ser reconhecidas pelas proteínas $\alpha$ - ou $\beta$-importina, que as translocam através do poro do núcleo celular ${ }^{69}$. A própria sequência do PTD também costuma servir como um NLS, devido a sua carga positiva, ajudando na passagem seletiva da barreira que impede a entrada de proteínas maiores de $40 \mathrm{kDa}$, através do envelope nuclear. Em nosso laboratório já foi utilizado com sucesso o peptídeo TAT fusionado à proteína $\mathrm{p} 27^{\mathrm{kip} 1}$ recombinante ${ }^{70}$, produzida em bactérias conforme outros grupos ${ }^{71}$, que foi capaz de inibir a proliferação celular in vitro e em modelo de injúria vascular in vivo. 


\subsection{Novas abordagens para utilização da TAT}

A entrega de proteínas de fusão recombinantes com PTDs vem sendo desenvolvida desde final dos anos 90 em diversas áreas, e algumas limitações para aplicação direta no uso terapêutico foram sendo observadas. Uma das situações é na injeção direta na circulação, ou no leito tumoral, com o propósito de tratamento para regressão de tumor ${ }^{72}$. Isso decorre do fato de que uma quantidade significativa de proteína recombinante não consegue atingir todas as células dentro da massa do tumor e as proteínas no meio extracelular não incorporadas são degradadas gradualmente por proteases e/ou estão sujeitas à filtração renal rápida. Consequentemente, se um efeito contínuo da proteína de fusão recombinante TAT é necessário, seja in vitro ou in vivo, a administração por repetidas vezes também se faz. Além disso, as proteínas recombinantes de E. coli não apresentam modificações pós-traducionais que podem ser importantes na função da proteína em algumas circunstâncias. Sistemas de expressão com células eucarióticas, principalmente de mamíferos, em contrapartida, permitem a produção de proteínas recombinantes com modificações pós-traducionais que são importantes para muitas propriedades farmacológicas

De maneira a modelar situações de complexas interações entre células, culturas de tipos celulares distintos podem ser desenvolvidas através do compartilhamento do mesmo meio de cultura. Esse processo é denominado cocultura (ou co-cultivo) e permite que as células sejam estimuladas pelo seu contato físico ou por moléculas, como citocinas, produzidas pelo outro tipo celular (efeito parácrino). Hoje existem diversos sistemas que permitem fazer co-cultura sem que 
haja contato físico entre os diferentes tipos celulares com aplicações nas mais diversas perguntas ${ }^{73}$. Um dos sistemas que é bastante empregado na literatura é o Transwell $^{\circledR}$. Nele uma membrana permeável contendo poros de variados tamanhos feita de poliéster, policarbonato ou politetrafluoroetileno, recoberta com colágeno, é utilizada para separar dois tipos celulares distintos em compartimentos isolados. No contexto de utilização das PTD, esse sistema foi utilizado para co-cultivar "células alvo" com células 'produtoras', modificadas para produzir e secretar continuamente a proteína de interesse fundida ao PTD ${ }^{74}$. É uma interessante solução in vitro, pois permite o efeito contínuo da proteína de fusão nas células-alvo, de maneira análoga ao que já foi feito com retrovírus ${ }^{75}$. Dessa forma, as proteínas secretadas recombinantes são capazes de entrar nas células adjacentes, promovendo sua função por todo período em que a células produtoras estão em contato. Cerca de um ano após o início do nosso projeto, Flintermann e cols ${ }^{76}$, também usando abordagem com transwell, demonstraram que o peptídeo TAT pode ter sua sequência de aminoácidos modificada sem perder sua eficiência de transdução, sendo denominada TATк (YARKAARQARA). Dessa maneira impede-se que haja ação de endoproteases furinas, enzimas da família das subtilisinas que estão localizadas tanto no Complexo de Golgi como no citoplasma e reconhecem e clivam proteínas contendo a sequência consenso RxRR ou RxKR, onde $x$ pode ser qualquer aminoácido. Consequentemente, uma vez que o peptídeo sinal e a TAT costumam ser colocadas na porção N-terminal, promovendo essa modificação é possível aumentar os níveis de produção e secreção pelas células produtoras e a subsequente captação das proteínas pelas células alvo. 


\subsection{A proposta}

Colocadas em conjunto, todas essas evidências supramencionadas serviram de substrato para elaborarmos uma inovadora estratégia que seria de grande valia para ser testada como candidata para reprogramar células ao estado pluripotente. $\mathrm{Na}$ época em que o projeto foi proposto existiam alguns trabalhos que demonstravam que o fenômeno de reprogramação era legítimo e extensível às células humanas (Figura 1). Contudo, a necessidade de não se utilizar vírus era latente e ainda não tinha sido publicada nenhuma alternativa. Tampouco tinham sido elucidadas algumas questões biológicas fundamentais dessas células, tais como se a integração viral era necessária para que o processo de reprogramação acontecesse ${ }^{77,78}$, ou se os fatores poderiam ser entregues em diferentes quantidades para que o processo ficasse mais eficiente $^{79}$.

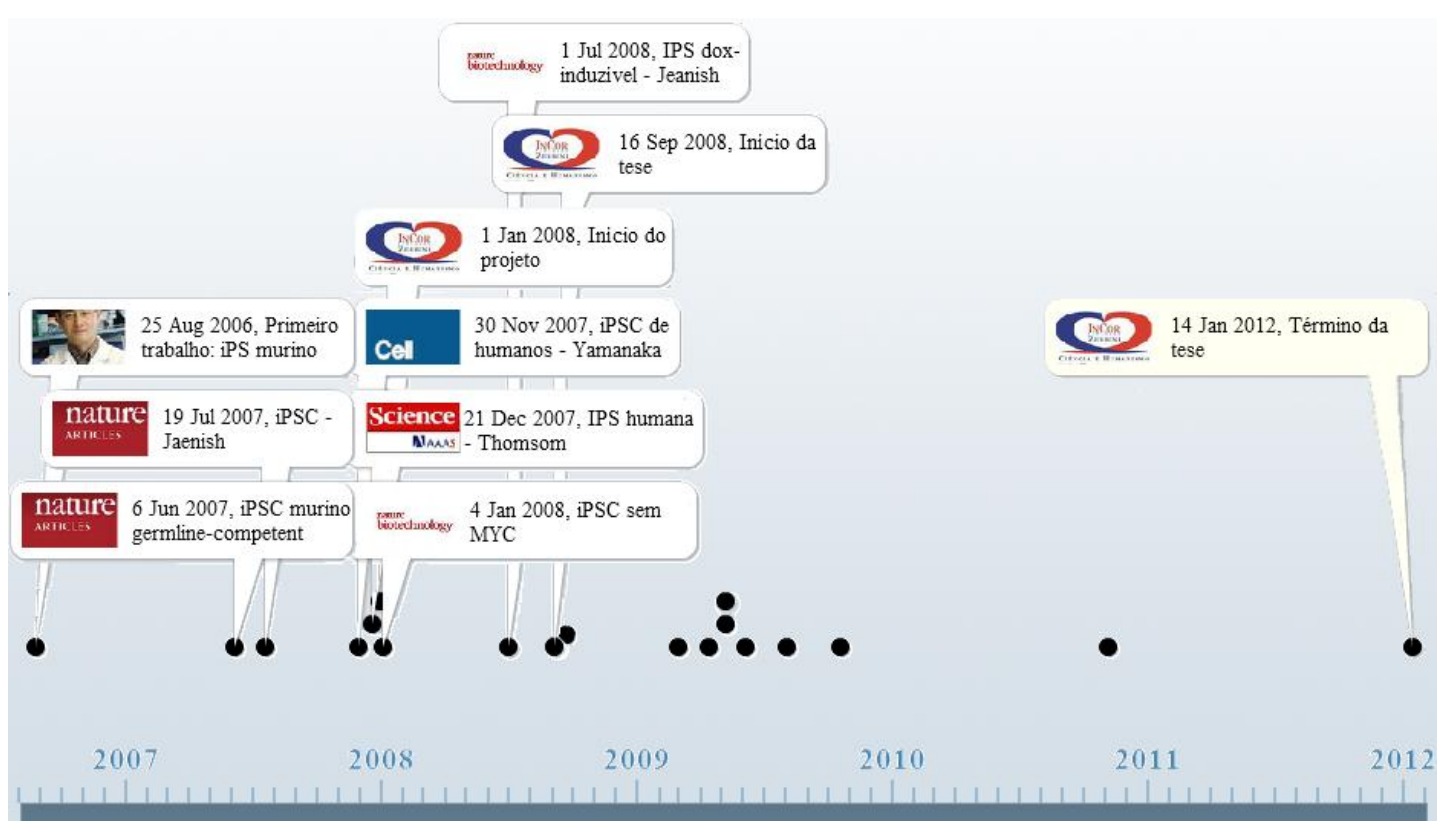

Figura 1: Linha do tempo das principais publicações relacionadas às células iPS até o período do início do projeto. 
Outro aspecto interessante que foi levantado na elaboração desse projeto e que ainda não havia sido elucidado foi o fato de que tentar reprogramar células com algum grau de plasticidade, como as células mesenquimais de tecido adiposo, poderia ser mais eficiente do que células terminalmente diferenciadas. Além disso, foram sendo incorporadas ao nosso projeto, abordagens acessórias para aumentar a eficiência de reprogramação, como a utilização de lítio ${ }^{80}$ e ácido valpróico ${ }^{81}$ e o cultivo das células em hipóxia ${ }^{82}$; esse último parece ser crítico inclusive para a manutenção de outros tipos de células-tronco ${ }^{83}$. 
2. Objetivos 


\subsection{Objetivo geral}

O presente trabalho objetivou verificar a hipótese de que os fatores de transcrição OCT3/4, SOX2, KLF4 e c-MYC fusionados ao peptídeo carreador TAT possam promover a reprogramação de fibroblastos e/ou células mesenquimais de tecido adiposo de camundongos (mASC) e humanos (hASC) em células iPS.

\subsection{Objetivos específicos}

Para que a hipótese maior pudesse ser testada, procurou-se atingir os seguintes objetivos específicos:

a) Estabelecer no laboratório, utilizando vetores virais, as linhagens de células iPS murinas e humanas que serviram como modelo de comparação para reprogramação à célula pluripotente;

b) Gerar todos os plasmídeos contendo a s sequências de interesse;

c) Padronizar os métodos de detecção de proteína no meio de cultura - fluorescente (para GFP) e de ELISA (para os fatores de transcrição);

d) Substituir o peptídeo carreador TAT pelo TATא, que não é sensível às endoproteases citoplasmáticas;

e) Estabelecer um método eficiente para promover a produção e entrega dos fatores de transcrição. 
3. Materiais e Métodos 


\subsection{Extração de células para cultura primária}

\subsubsection{Mesenquimais de tecido adiposo}

As células mesenquimais de tecido adiposo humano ( $h A S C$, human adipose stem cell) foram extraídas de material de descarte de cirurgias de lipoaspiração e as células mesenquimais de tecido adiposo murino (mASC, mouse adipose stem cell) da região inguinal de camundongos Swiss, conforme já estabelecido no laboratório e com aprovação no Comitê de Ética e pesquisa da FMUSP (Anexo A e Anexo B). Ambas já foram previamente caracterizadas quanto à capacidade de proliferação, presença de marcadores moleculares e diferenciação em tipos celulares distintos (adiposo e ósseo) ${ }^{84-86}$ em cultura. Após obtenção do material e lavagem com tampão fosfato (PBS, do inglês Phosphate Buffered Saline), o tecido foi incubado a $37^{\circ} \mathrm{C}$ por 30 minutos em meio de cultura DMEM Low Glucose (DMEM Low; Invitrogen, Carlsbad, CA) acrescido de 0,075\% colagenase e albumina sérica bovina (BSA, do inglês Bovine Serum Albumin; Sigma, St. Louis, MO). Após esse período, as enzimas foram inativadas adicionando-se soro fetal bovino a 10\% (FBS, do inglês Fetal Bovine Serum; Invitrogen). Em seguida, a preparação foi centrifugada e o precipitado de alta densidade formado foi ressuspendido em DMEM Low suplementado com $10 \%$ de FBS e $1 \%$ penicilina/estreptomicina (P/S, Invitrogen). Posteriormente, esse volume foi plaqueado em placas de $100 \mathrm{~mm}$ e armazenado em estufa à $37^{\circ} \mathrm{C}$ com $5 \%$ de $\mathrm{CO}_{2}$. Durante três dias seguidos, a cada 24 horas, cada placa foi lavada com tampão PBS e o meio de cultura trocado, de forma a remover gradativamente as hemácias e debris celulares oriundos da extração. Após esses três dias, o meio de cultura foi trocado a cada 48h-72h, dependendo do rendimento da extração. Quando as células alcançavam $80 \%$ de confluência, as placas eram tripsinizadas $(0,25 \%$ 
tripsina-EDTA) e a cultura expandida para garrafas de $75 \mathrm{~cm}^{2}$. As hASC e mASC foram cultivadas em meio DMEM Low suplementado com $10 \%$ de FBS e $1 \%$ P/S e foram expandidas e congeladas até a passagem 4 para garantir uniformidade dentre os experimentos que seguirão.

\subsubsection{Fibroblastos embrionários murinos}

Fibroblastos embrionários de murinos (MEF, mouse embryonic fibroblasts) foram utilizados como feeder das células geradas ou transduzidos com vírus ou proteínas para geração de células iPS. Essas células foram obtidas conforme descrito anteriormente ${ }^{87}$. Em resumo, embriões de camundongos Swiss (14 dias pós-coito) tiveram o saco vitelínico e víceras removidos e, em seguida, fragmentados em pequenos pedaços com auxílio de uma tesoura. Os fragmentos foram incubados em tampão de digestão (DMEM Low suplementado com $0,25 \%$ tripsina porcina de pâncreas e $0,02 \%$ EDTA, $5 \mathrm{~mL}$ por embrião) a $37^{\circ} \mathrm{C}$ por 45 minutos. Em seguida, a solução foi posta para decantar e o sobrenadante plaqueado em garrafas T.150 (na proporção de um embrião por garrafa), com $20 \mathrm{~mL}$ de meio de cultura para MEF (DMEM Low suplementado com 15\% soro de bezerro (BCS, Bovine calf serum, Hyclone), $1 \%$ de L-Glutamina e $1 \%$ de P/S. Após 24h, já era possível se observar células aderidas. Para os experimentos de geração de iPS, foram utilizadas células na passagem 1. Para obtenção das células feeder, as células foram repicadas a cada 2-3 dias até a passagem 3, quando tiveram a proliferação inibida com mitomicina $\mathrm{C}^{88}$.

\subsubsection{Fibroblastos de pele de prepúcio}

Fibroblastos de pele de prepúcio (HFF, do inglês Human Foreskin Fibroblasts) foram obtidos por explante a partir do protocolo de Akira Takashima ${ }^{89}$. 
Em resumo, a pele do prepúcio era lavada com PBS e cortadas em pedaços de aproximadamente $5 \mathrm{~mm}^{2}$ e colocadas em placas de 6 poços. Após aproximadamente 4-5 dias, fibroblastos e queratinócitos começavam a migrar e proliferar. Assim que o poços ficavam confluentes, eles eram repicados com tripsina por tempo suficiente para que apenas os fibroblastos se soltassem e passados para garrafas na concentração de $1 \times 10^{4}$ células. Como os fibroblastos aderem menos firmemente e proliferam em velocidade maior que os queratinócitos, em aproximadamente 21 dias cultivando em DMEM (Invitrogen, Carlsbad, CA) suplementado com 10\% FBS, obteve-se uma população pura de fibroblastos.

\subsection{Produção de LIF}

O plasmídeo de expressão de LIF foi transfectado em células COS-7, em placas de 100mm, pelo método de precipitação por cálcio com choque de glicerol. Após quatro dias, o meio de cultura contendo LIF foi coletado, filtrado em $0,22 \mu \mathrm{m}$ e armazenado a $-80^{\circ} \mathrm{C}$. Em seguida, para determinar a quantidade de uso do LIF produzido, foram plaqueadas 3000-5000 células E14TG2a em cada poço de uma placa de 24 poços e realizada uma curva de dose de LIF. Após cinco dias, por meio do ensaio de atividade de fosfatase alcalina nessas células, foi possível se observar as concentrações mais baixas de LIF que permitam o aparecimento de células diferenciadas na cultura. Foi escolhida, portanto, uma quantidade de sobrenadante que mantenha a as células E14TG2a indiferenciadas.

\subsection{Geração de células iPS utilizando vírus}

\subsubsection{Células iPS murinas}


MEFs foram reprogramados a células iPS pelo método desenvolvido por Yamanaka e cols ${ }^{90}$, com pequenas modificações.

Primeiramente os vírus MMLVs (Moloney Murine Leukemia Vírus) foram produzidos em células HEK-293t transfectadas, em separado, com os vetores oncoretrovirais pMX contendo a sequência murina para cada um dos genes necessários para a reprogramação: Oct3/4, Sox2, Klf4 e c-Myc (Addgene, Cambridge, MA). Além disto, foi produzido também o vírus eGFP (pMX para eGFP, construído no laboratório). Após 48h de transfecção, o sobrenadante foi coletado, filtrado a $0,45 \mu \mathrm{m}$ e ou congelado a $-80^{\circ} \mathrm{C}$ ou utilizado para transdução. Em paralelo ao processo de geração de iPS, o vetor retroviral eGFP foi utilizado para infectar $1 \times 10^{5}$ células $\mathrm{NIH}$ e/ou MEF, em placas de $60 \mathrm{~mm}$ e serviram como indicador da eficiência da transdução retroviral.

Uma vez estabelecida a eficiência da produção dos vírus pelo eGFP, MEFs na passagem 1 foram plaqueados na concentração de $1 \times 10^{6}$ células em placas de $100 \mathrm{~mm}$ gelatinizadas e infectados com $500 \mu \mathrm{L}$ do sobrenadante de cada um dos 4 vírus, na presença de $8 \mu \mathrm{g} / \mathrm{mL}$ polibreno (Sigma). Após cinco dias, as células foram repicadas e $5 \times 10^{4}$ células foram plaqueadas em uma placa de $100 \mathrm{~mm}$ contendo $8 \times 10^{5}$ células feeder previamente preparada. No dia seguinte, foi adicionado meio de iPS (DMEM High suplementado com 15\% de Knockout Serum Replacer, 1\% MEM aminoácidos não essenciais, $1 \%$ L-Glutamin, $0.1 \mathrm{mM} \beta$-mercaptoetanol, 50U/mL $\mathrm{P} / \mathrm{S}$ (todos Invitrogen) e fator inibidor de leucemia murino (LIF)). Após aproximadamente duas semanas começaram a surgir colônias de células, que foram acompanhadas por até quatro semanas. Após esse período, as colônias foram meticulosamente enumeradas, fotografadas e transferidas para placas de 24 poços 
previamente preparadas com células feeder. É importante ressaltar que, diferentemente do utilizado por Yamanaka ${ }^{49,90}$, os MEFs utilizados não apresentam gene repórter como indicador de sucesso da reprogramação (Fbox15 e Nanog). Portanto, a seleção inicial das colônias iPS foi baseada apenas na sua morfologia característica (conforme Jaenish ${ }^{51}$ ).

\subsubsection{Células iPS humanas}

Foram utilizados três diferentes sistemas para tentar reprogramar as células de humanos (Aqui definidos como lentivírus pSin, Coloridos e Stemcca). Uma vez estocada a produção, os vírus (em diferentes quantidades) foram colocados em contato com fibroblastos de pele ou células hASC, na presença de $8 \mu \mathrm{g} / \mathrm{mL}$ polibrene.

$p \operatorname{Sin}$

O primeiro a ser testado foi o sistema de plasmídeos pSin, o mesmo utilizado pelo grupo do Thomson, com um protocolo com algumas modificações ${ }^{55,91}$. Os plasmídeos pSIN-EF2-Pur (Addgene - http://www.addgene.org) contendo as sequencias de gene de humanos de OSNL, juntamente do plasmídeo codificando o envelope VSV-g e do plasmídeo pCMV $\Delta$ R8.91 expressando Gag, Pol, Tat, and Ver (7 $\mu \mathrm{g}$ pCMV $\Delta \mathrm{R} 8.91 ; 5 \mu \mathrm{g}$ VSV-G e $10 \mu \mathrm{g}$ do backbone - total de $22 \mu \mathrm{g}$ ), foram transfectados em células 293t previamente plaqueadas em 10 placas de 60mm tratadas com gelatina $0,1 \%$ em meio de cultura DMEM suplementado com $10 \%$ BCS. Utilizou-se o método de precipitação de cálcio ou Lipofectamina (conforme instruções do fabricante). Nos dois dias seguidos após a transfecção, a cada 24 h o meio de cultura foi coletado, concentrado por ultracentifugação a $4^{\circ} \mathrm{C}$ usando a 
centrífuga Beckman Optima L-90k (Beckman Coulter, Inc., Palo Alto, CA, USA) a $80.000 \mathrm{~g}$ por $1 \mathrm{~h}$ com rotor $\mathrm{SW} 32 \mathrm{Ti})$ e armazenado à $-80^{\circ} \mathrm{C}$.

Para a transdução, $10 \mu \mathrm{L}$ de volume de cada concentrado de vírus (OSLN) foram adicionados a $1 \mathrm{~mL}$ de meio de cultura DMEM Low suplementado com $10 \%$ FBS e $8 \mu \mathrm{g} / \mathrm{mL}$ polibreno em 2 placas de 6 poços previamente plaqueadas com $1 \times 10^{5}$ por poço de células hASC ou fibroblastos de pele. Após cinco dias, essas células foram transferidas para placas de $100 \mathrm{~mm}$ previamente plaqueadas com $8 \times 10^{5}$ MEF feeder e mantidas em meio DMEM High suplementado com 15\% de Knockout Serum Replacer, 1\% MEM aminoácidos não essenciais, 1\% L-Glutamina, 0,1 mM $\beta$-mercaptoetanol, 50U/mL P/S e 10ng/mL de FGF-2 (todos Invitrogen). Após aproximadamente 20 a 30 dias as colônias que surgiram foram transferidas para placas de 12 poços, previamente plaqueadas com células MEF feeder.

\section{Lentivírus coloridos}

O segundo sistema a ser utilizado em nosso laboratório foi o de plasmídeos com repórter colorido, do grupo do Sadelain ${ }^{79}$. Esse sistema apresenta os mesmos genes do primeiro trabalho do Yamanaka (OSKM), mas com sequências de humanos fusionado aos genes coloridos por peptídeo 2A (respectivamente vexGFP, Citrine, mCherry e Cerulean). A produção dos vírus foi feita de maneira semelhante ao vírus pSin, transfectando as células 293t com $7 \mu \mathrm{g}$ psPAX, 2,5 $\mu \mathrm{g}$ VSV-G e $10 \mu \mathrm{g}$ do backbone, num total de $22 \mu \mathrm{g}$, mas utilizando-se apenas o método de cálcio. Nos dois dias seguidos após a transfecção, a cada $24 \mathrm{~h}$ o meio de cultura foi coletado, concentrado por ultra-centifugação e armazenado à $-80^{\circ} \mathrm{C}$ para posterior utilização. A transdução também foi feita de maneira semelhante ao pSin, contudo, antes de dar 
seguimento à reprogramação, as células foram levadas ao citômetro de fluxo com capacidade de separação de células (FACSAria II, BD Biosciences). O objetivo foi verificar se houve a transdução e coletar apenas as células os tipos de 4 vírus foram transduzidos concomitantemente.

\section{STEMCCA}

O terceiro sistema a ser empregado também se utiliza de lentivírus para promover a reprogramação, contudo com o vírus carreando os 3 ou 4 genes (OSKM) de uma vez, Mostoslavsky e colaboradores ${ }^{92}$, quem, gentilmente, nos forneceu os plasmídeos. Em resumo, $2 \times 10^{6}$ células 293 t previamente plaqueadas em 20 placas de $60 \mathrm{~mm}$ tratadas com gelatina $0,1 \%$, foram transfectadas com 5 plasmídeos $(0,6 \mu \mathrm{g}$ TAT; $0,6 \mu \mathrm{g}$ REV; $0,6 \mu \mathrm{g}$ GAG; $1,2 \mu \mathrm{g}$ VSV-G e $12 \mu \mathrm{g}$ do backbone) num total de $15 \mu \mathrm{g}$ de DNA usando o método de cálcio com choque de glicerol ou de Lipofectamina (Invitrogen). Nos dois dias seguidos após a transfecção, a cada $24 \mathrm{~h}$ o meio de cultura $(2 \mathrm{~mL})$ foi coletado, concentrado por ultracentifugação $4^{\circ} \mathrm{C}$ usando a centrífuga Beckman Optima L-90k (Beckman Coulter, Inc., Palo Alto, CA, USA) a $80.000 \mathrm{~g}$ por $1 \mathrm{~h}$ com rotor $\mathrm{SW} 32 \mathrm{Ti}$ ) e utilizado fresco nas células e o restante que sobrou armazenado em alíquotas de $60 \mu \mathrm{L}$ à $-80^{\circ} \mathrm{C}$.

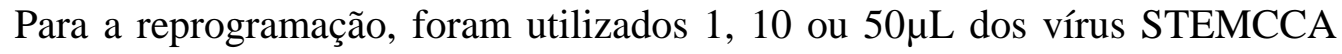
ou RED-STEMCCA em $0,8 \mathrm{~mL}$ de meio de cultura com polibreno a $8 \mu \mathrm{g} / \mathrm{mL}$ em 2 placas de 6 poços com $1 \times 10^{5}$ células por poço (fibroblastos humanos de pele). Cinco dias após a transdução, com trocas de meio diárias e depois de checada a infecção no microscópio de fluorescência, as células foram passadas para quatro placas de 6 poços com $2 \times 10^{5}$ células de feeder pré-plaqueadas. Foi utilizado a diluição de 1/200 
ou a passagem de $1 \times 10^{5}$ células por poço e a partir desse ponto passou-se a utilizar o meio de cultura mTeSR1 (StemCell Technologies, Grenoble, France), que é específico de hES (do inglês Human Embryonic Stem Cell). Após cerca de 15 dias da transdução, sempre com trocas de meios diárias, começaram a aparecer colônias que se mostraram posteriormente ter morfologia bastante característica de $\mathrm{hES}$, em formato achatado. Elas foram coletadas e expandidas para outras placas de 6 poços pré-plaqueadas com células MEF feeder. Além disso, a coleta foi feita com dispase $(1,0 \mathrm{mg} / \mathrm{mL})$, incubada por $10 \mathrm{~min}$ a $37^{\circ} \mathrm{C}$ e por pipatagem, upside and down $3-4$ vezes para soltar e para quebrar as colônias em agregados menores, sem fazer as células ficarem individualizadas. Esse aspecto não tinha sido levado em consideração anteriormente.

\subsection{Caracterização das células iPS}

\subsubsection{RT-PCR para genes marcadores de células-tronco pluripotentes}

A expressão dos marcadores específicos de ES foi avaliada por RT-PCR $\left(95^{\circ} \mathrm{C}\right.$ para separação das fitas, seguido de anelamento a $60^{\circ} \mathrm{C}$ e extensão a $72^{\circ} \mathrm{C} ; 28$ ciclos) utilizando oligonucleotídeos específicos (o "m" e o " $\mathrm{h}$ ” na frente do nome dos genes indica, respectivamente, a especificaidade do primer para camundongos (mouse) e humanos). Foram utilizados os genes já descritos na literatura como importantes para manutenção da pluripotência celular de ES (Eras, Esg, Rex1 e Hprt) bem como os fatores usados para a reprogramação (Klf4, Oct4 e Sox2). 
Tabela 1: Oligonucleotídeos utilizados para verificação de reprogramação nuclear de camundongos.

\begin{tabular}{|c|c|}
\hline Óligo & Sequência \\
\hline mERAS-F & 5' - CATCCAGATGACTCACCAATGCTTCGTG - 3' \\
\hline mERAS-R & 5' - TGGACCATATCTGCTGCAACTGGTCCAG - 3' \\
\hline mESG1-F & 5' - AATATCTGTTTGGCCCACAGGGATCTCG - 3' \\
\hline mESG1-R & 5' - TCATGGATTCCTCCAGCTTCAGCACTC - 3' \\
\hline mREX1-F & 5' - CTGACGGATACCTAGAGTGCATCATACGAG - 3' \\
\hline mREX1-R & 5' - AGTACACACCGCCCTCTGGCTTCTCTGCAG - 3' \\
\hline mKLF4-F & 5' - CTGCCAGACCAGATGCAGTCACAAGTC - 3' \\
\hline mKLF4-R & 5' - CTCGCCTGTGTGAGTTCGCAGGTGTGC - 3' \\
\hline mOCT3/4-F & 5' - GACAACAATGAGAACCTTCAGGAGATATGC - 3' \\
\hline mOCT3/4-R & 5' - CCAAGCTGATTGGCGATGTGAGTGATCTGC - 3' \\
\hline mSOX2-F & 5' - GTGAACCAGCGCATGGACAGCTACGCGC - 3' \\
\hline mSOX2-R & 5' - TCGTAGCGGTGCATCGGTTGCATCTGTGC - 3' \\
\hline mHPRT-F & 5' - CACAGGACTAGAACACCTGC - 3' \\
\hline mHPRT-R & 5' - GCTGGTGAAAAGGACCTCT - 3' \\
\hline mAFP-F & 5' - GGCAGTGTTCATGAACAGGTTCATCTATG - 3' \\
\hline mAFP-R & 5' - CTTAGCTTAATAATGGTTGTTGCCTGG - 3' \\
\hline mNESTIN-F & 5' - GTCTGGAAGTGGCTACATACAGGACTCTGC - 3' \\
\hline mNESTIN-R & 5' - AGGCTGTCACAGGAGTCTCAAGGGTATTAG - 3' \\
\hline mSMA-F & 5' - GCTATTCCTTCGTGACTACTGCCGAGCG - 3' \\
\hline mSMA-R & 5' - TGAAAGATGGCTGGAAGAGAGTCTCTGG - 3' \\
\hline
\end{tabular}

\subsubsection{Ensaio fosfatase alcalina}

O ensaio para determinação da atividade de fosfatase alcalina (Leukocyte Alkaline Phosphatase Kit) foi realizado em placas de 24 poços e seguindo instruções do fabricante (Sigma).

\subsubsection{Formação de teratomas e análise histológica}

Dois milhões de células foram implantadas subcutaneamente no flanco dorsal de camundongos nude adquiridos e mantidos no Departamento de Imunologia do ICB IV. Quatro semanas após a injeção, os tumores foram dissecados e fixados em formaldeído $10 \%$ ou preparados para extração de RNA com trizol. Os tecidos foram 
cortados e processados para análise histologica por coloração de hematoxilina e eosina ou realização de RT-PCR.

\subsubsection{Geração de quimeras}

Esse ensaio foi realizado em colaboração com o pós-doutorando Christian Albert Merkel. Resumidamente, animais C57 BL10 injetados para superovulação com gonadotrofina coriônica (PMSG e HCG) foram postos para acasalar e embriões no estágio de mórula foram obtidos por lavagem dos cornos uterinos após $48 \mathrm{~h}$. Em seguida, após o desenvolvimento dos embriões ao estágio de blastocisto, eles foram colocados em uma gota de DMEM com 15\% FCS sob óleo mineral. No micromanipulador, com agulha de 12 a 15mm de diâmetro interno, de 10 a 15 células iPS GFP+ foram injetadas na cavidade de cada blastocisto. Finalmente, injetaram-se 20 blastocistos em um dos cornos uterinos de cada fêmea, para maximizar a eficiência do processo.

\subsubsection{Diferenciação in vitro das iPS}

De forma a se verificar a possibilidade de indução em diferenciação endotelial, as iPS geradas foram submetidas a shear stress controlado usando um viscômetro de cone plate gentilmente cedido por G.H. Gibbons ${ }^{93,94}$. Células foram plaqueadas em placas de $150 \mathrm{~mm}$ com $40 \mathrm{~mL}$ de meio de cultura de indução de diferenciação sem LIF (DMEM High suplementado de 20\% de FBS, $0.1 \mathrm{mM} \beta$-mercaptoetanol, $1 \%$ MEM aminoácidos não essenciais, $1 \%$ de L-glutamina, $1 \%$ penicilina/ estreptomicina) e submetidas a shear stress $\left(10\right.$ dinas $\left./ \mathrm{cm}^{2}\right)$ por diferentes tempos (1, 2 e 7 dias) e mantidas a $37^{\circ} \mathrm{C}$ com uma mistura de $5 \% \mathrm{CO}_{2}$. Ao fim do experimento 
as células foram lavadas com PBS e processadas adequadamente para análise de marcadores de célula endotelial por citometria de fluxo ou RT-PCR.

\subsection{Preparação dos plasmídios contendo as sequências de interesse}

Para execução de todo processo, o aluno teve supervisão do prof. Bryan E. Strauss, que tem grande experiência em vetores virais e a colaboração do pósdoutorando Chester B. Sacramento.

A preparação dos plasmídios foi feita de maneira modular. Primeiramente, oligonucleotídeos específicos foram adquiridos (Invitrogen e IDT; tabela 1) e esses foram anelados e amplificados para introduzir sítios de restrição adequados nos genes eGFP, Sox2, Oct3/4, Klf4 e c-Myc (do vetor pMX). Em seguida, eles foram ligados de maneira específica e organizada ao peptídeo TAT ou TATк no vetor de expressão pSecTag2 (Invitrogen, Carlsbad, CA), conforme pode ser observado na figura 2 abaixo. Vale ressaltar que a publicação recente na literatura ${ }^{76}$ que demonstrou que mutações nos sítios de reconhecimento de furinas da sequência da TAT é capaz de aumentar de maneira muito significativa a produção, o padrão de localização celular e capacidade de penetração das proteínas nas células alvo.

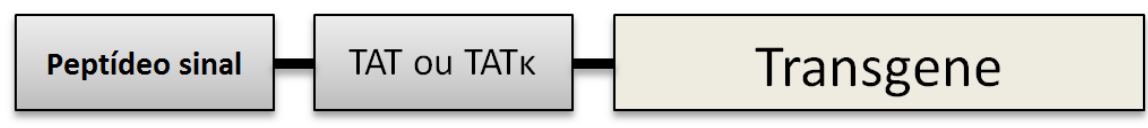

Figura 2: Representação esquemática das proteínas geradas pelos vetores de expressão pSecTag2 e pCL-X-SN. Essa organização é possível devido aos diferentes sítios de restrição de cada módulo.

Esse vetor de expressão foi escolhido, pois ele apresenta na região N-terminal um peptídeo sinal denominado murine Ig $\kappa$-chain leader, que sinaliza a secreção da proteína. Na porção C-terminal encontra-se a sequência da proteína de interesse 
(fator de transcrição), a qual pode também ser a eGFP para permitir se realizar ensaios que demonstrem que o sistema está funcionando. As orientações dos fragmentos foram confirmadas por digestões com enzimas de restrição e sequenciamento automático.

Em seguida, a construção para cada um dos genes de interesse foi inserida no plasmídeo retroviral pCLXSN (Imgenex ${ }^{95}$ ). Esse sistema foi escolhido, pois, diferentemente do pMX, permite que as células produtoras sejam selecionadas pela resistência ao antibiótico geneticin das células que serão transduzidas. A confirmação do inserto correto foi realizada usando-se enzimas de restrição e sequenciamento automático. Depois de confirmada, realizou-se Maxi-prep (Quiagen) para purificação dos plasmídios e produção dos retrovírus conforme descrito no item 3.11.1. 
Tabela 2: Oligonucleotídeos utilizados para construção dos plasmídeos.

F e R indicam, respectivamente, óligos forward e reverse.

\begin{tabular}{|c|c|}
\hline Óligo & Seqüiência \\
\hline OCT-4 KpnI - F & $5^{\prime}$ gatcggtaccatggctggacacctggettcagac $3^{\prime}$ \\
\hline OCT-4 Bgl II - R & 5' aatgagatct tcagtttgaatgcatgggagagcc 3 ' \\
\hline $\begin{array}{ll}\text { SOX-2 KpnI - F } \\
\end{array}$ & $5^{\prime}$ gatcggtacc atgtataacatgatggagacggag $3^{\prime}$ \\
\hline SOX-2 BamHI - R & $5^{\prime}$ gtaaggatcc tcacatgtgcgacaggggcagtgt $3^{\prime}$ \\
\hline KLF-4 KpnI - F & 5' gatcggtaccatggctgtcagcgacgctctgctc $3^{\prime}$ \\
\hline KLF-4 BamHI - R & 5' ctaaggatccttaaaagtgcctcttcatgtgtaa $3^{\prime}$ \\
\hline c-Myc KpnI - F & $5^{\prime}$ gatcggtaccctggatttcctttgggcgttggaa $3^{\prime}$ \\
\hline c-Myc BamHI - R & 5' ctaaggatcc ttatgcaccagagtttcgaagctg 3' \\
\hline eGFP KpnI - F & 5' gatcggtaccatggtgagcaagggcgaggagctg 3' \\
\hline eGFP BamHI - R & $5^{\prime}$ gtaaggatcc ttacttgtacagctcgtccatgcc $3^{\prime}$ \\
\hline pSECTag Bgl II - F & 5' agggagatctaagctggctagccaccatgg $3^{\prime}$ \\
\hline pSECTag $R$ & $5^{\prime}$ gtgctggatatctgcagaattccaccacac $3^{\prime}$ \\
\hline pSECTag Eco RI - F & $5^{\prime}$ aggggaattcaagctggctagccaccatgg $3^{\prime}$ \\
\hline $\begin{array}{ll}\text { pSECTag } & \text { R2 }\end{array}$ & 5' gggccctcctcgagcggccgccactgtgctgg 3' \\
\hline TAT Asc-Kpn Top & 5' cgcgcetacggccgcaagaaacgccgccagcgccgccgcggtac 3' \\
\hline TAT Asc-Kpn Bottom & $5^{\prime}$ cgcggcggcgctggcggcgtttcttgcggccgtagg $3^{\prime}$ \\
\hline $\begin{array}{ll}\text { TATкарра Asc-Kpn Top } \\
\end{array}$ & $5^{\prime}$ cgcgcctacgctcgaaaagcagcacgacaagcacgagcaggtac $3^{\prime}$ \\
\hline $\begin{array}{ll}\text { TATкарра } & \text { Asc-Kpn Bottom }\end{array}$ & $5^{\prime}$ ctgctcgtgcttgtcgtgctgcttttcgagcgtagg $3^{\prime}$ \\
\hline
\end{tabular}

\subsection{Análises de Citometria e cell sorting}

A verificação de fluorescência derivada do GFP nas células foi realizada utilizando-se citometria de fluxo. Após terem sido tripsinizadas e centrifugadas, as células foram contadas e ressuspendidas de forma a se obter $1,0 \times 10^{6}$ células por tubo exceto quando é explicitado no texto. Em seguida, as células foram incubadas por pelo menos 1 hora em $4 \%$ paraformaldeido para que houvesse a possibilidade da análise conjunta dos tubos. A aquisição das células (10.000 eventos) e a análise dos fenótipos em parte foram realizadas utilizando-se o aparelho FACSCalibur e o software CellQuest Pro do laboratório do Prof. Dr. Roger Chammas. A seleção (sorting) de células foi realizada no aparelho FACSaria. 


\subsection{Irradiação de células para efetuar parada de ciclo celular}

Células 293A-pSec-TATк-OCT foram irradiadas no Instituto de Pesquisas Energéticas e Nucleares (IPEN-USP) com as células em suspensão em falcons de $50 \mathrm{~mL}$ à $4^{\circ} \mathrm{C}$ e meio de cultura trocada a cada 3 dias na sequência. $\mathrm{O}$ objetivo foi verificar uma dose de irradiação suficiente para que as células parassem de proliferar e mantivessem ao máximo sua viabilidade. Foram aplicadas doses de 2, 4, 6, 10 e 20 grays a partir de uma fonte Gammacell de ${ }_{60} \mathrm{Co}$.

\subsection{Detecção de fluorescência no meio de cultura}

Foi realizada a detecção de GFP diretamente em meio de cultura celular condicionado usando o fluorímetro Victor Wallac 1420 (Perking Elmer). Células foram cultivadas em placas de cultura de 96 poços, contendo $150 \mu \mathrm{L}$ de meio DMEM sem vermelho de fenol e suplementado com 1\% FBS ou BCS (ambos Invitrogen). Após o tempo indicado, $110 \mu \mathrm{L}$ foi transferido para uma placa preta de leitura de fluorescência de 96 poços, tomando-se o cuidado de evitar a formação de bolhas. A detecção foi realizada em 0,2 segundos, utilizando-se filtros para excitação em 485nm e emissão em 535nm, com powerlamp ajustado para 40.000 u.a., à temperatura ambiente.

\subsection{Verificação de viabilidade celular}

Células foram avaliadas quanto à viabilidade usando ensaio com brometo de 3(4,5-dimetil-2-tiazolil)-2,5-difenil-2H-tetrazólio (MTT) (Sigma). Em resumo, as células em placas de 96 poços foram incubadas $\left(37^{\circ} \mathrm{C}, 5 \%\right.$ de $\left.\mathrm{CO}_{2}\right)$ em $200 \mu \mathrm{L}$ de meio de cultura contendo 5mg/mL MTT (preparado em PBS) por 2,5 horas. Posteriormente, o meio de cultura foi removido e o produto metabólico gerado a 
partir do MTT (formazan dye) foi ressuspenso em $200 \mu \mathrm{L}$ de dimetilsulfóxido (DMSO; Sigma). Após aguardar alguns minutos para haver dissolução completa, a densidade óptica foi verificada a 560nm no espetrofluorimetro e subtraída do sinal de fundo, com leitura em 670nm.

\subsection{Verificação de concentração dos fatores de transcrição OCT, SOX, KLF e MYC por ELISA}

Uma vez que não há disponível nenhum kit comercial para que seja efetuada a determinação da concentração dos fatores secretados pelas células produtoras, foi necessário padronizar ensaios ELISA (sanduíche) com anticorpos comprados individualmente. Foram utilizados anticorpos não-conjugados e biotinilados para os 4 fatores de transcrição do estudo (OCT3/4, SOX2, KLF4 e cMYC, R\&D) e as suas respectivas proteínas recombinantes (Abnova).

Em geral, o procedimento consistiu em se incubar overnight o anticorpo nãoconjugado (captura) a $4^{\circ} \mathrm{C}$ com $50 \mathrm{ul} /$ poço. No dia seguinte, lavou-se três vezes com $200 \mu \mathrm{L}$ de PBS $0,5 \%$ de Tween e procedeu-se com 1,5 horas de bloqueio com $200 \mu \mathrm{L}$ de PBS BSA $2 \%$ a $37^{\circ} \mathrm{C}$. Na sequência, após lavar 3x com $200 \mu \mathrm{L}$ de PBS $0,5 \%$ de Tween as placas ficaram 1 hora incubando com proteína recombinante (ou amostra) a $37^{\circ} \mathrm{C}$.

Após mas um ciclo de lavagem, foi incubado o anticorpo biotinilado (detecção), diluído em PBS BSA 0,1\%, a $37^{\circ} \mathrm{C}$ por $1 \mathrm{hr}$. Em seguida, após o ciclo de lavagem, incubou-se 20 min a estreptavidina (R\&D) diluída 1:200 a temperatura ambiente (diluído em PBS BSA 2\%). Após um último ciclo de lavagem, procedeu-se com a revelação feita com kit da $\mathrm{RD}$. Para tal, $2 \mathrm{~mL}$ do color reagent $\mathrm{A}$ foi misturada com $2 \mathrm{~mL}$ do color reagent B e $100 \mu \mathrm{L}$ dessa solução foram aplicados a cada poço da 
placa e incubados por 50 min à temperatura ambiente, protegida da luz. Finalmente, $100 \mu \mathrm{L}$ da stop solution foi aplicada para parar a reação e permitir a verificação da absorbância em 450nm no espectrômetro

\subsection{Geração das linhagens para produção de TAT-fator}

\subsubsection{Geração dos Vírus}

Células produtoras virais, HEK-293t (293t), foram transfectadas pelo método de precipitação de cálcio, separadamente, com cada um dos genes indutores de reprogramação em iPS. Após $48 \mathrm{~h}$, o sobrenadante foi coletado e congelado a $-80^{\circ} \mathrm{C}$ para utilização posterior.

\subsubsection{Geração de das linhasgens retroNIH-TAT-fator}

Fibroblastos NIH-3T3 foram infectados, em separado, com cada um dos vírus gerados em placas de $60 \mathrm{~mm}$, overnight, na presença de $8 \mu \mathrm{g} / \mathrm{mL}$ de polibrene, colocando-se 500uL de cada um dos vírus previamente congelados. No dia seguinte, as placas foram lavadas com PBS e o meio de cultura trocado para assegurar a retirada dos vírus do contato das células. Após 48h, as células foram repicadas, plaqueadas em baixa confluência e tratadas por pelo menos 30 dias com geneticin na concentração de $1 \mathrm{mg} / \mathrm{mL}$, para seleção das células infectadas. Em paralelo, células que não foram transduzidas com os vírus foram também tratadas para se evidenciar o efeito completo do antibiótico ao longo do período. 


\subsection{Geração das linhagens para produção de TATא-fator}

\subsubsection{Geração de linhagens produtoras de fatores de transcrição usando pSecTAg2}

Tipos celulares diferentes podem apresentar diferentes susceptibilidades a diferentes métodos de transfecção e à seleção por diferentes concentrações de antibióticos ${ }^{74,96}$, bem como diferentes performances de expressão/secreção de proteínas transgênicas ${ }^{97}$. Portanto, células de diferentes linhagens disponíveis no laboratório (NIH-3T3, COS-7, CHO, HT-1080, 293a e 293t) foram transfectadas com os plasmídios pSecTag2 (contendo cada um dos quatro fatores) utilizando-se o método de transfecção por fosfato de cálcio (kit da invitrogen, número de catálogo K2780-01) e Lipofectamina2000 ${ }^{\circledR}$ (Invitrogen), conforme instruções do fabricante. Em resumo, para Lipofectamina, $4 \mu \mathrm{g}$ de plasmídeo foi combinado a $10 \mu \mathrm{L}$ de Lipofectamina e incubado por $3 \mathrm{~h}, 6 \mathrm{~h}$ ou de um dia para o outro com as células. Para o método de cálcio, $9 \mathrm{uLde} 2 \mathrm{M} \mathrm{CaCl}_{2}$ e $5 \mathrm{ug}$ de plasmídeo foram diluídos em $75 \mu \mathrm{L}$ de água e esse foi lentamente combinado com $75 \mu \mathrm{L}$ de 2 x HBS (do inglês Hanks' Balanced Salts). Após 4horas, em contato com as células, o meio de cultura foi removido e foi realizado choque de DMSO ou glicerol.

$\mathrm{Na}$ sequência, as células foram selecionadas com Zeocin (Invitrogen), com trocas de meio a cada 2-3 dias, na concentração final de $0,5 \mathrm{mg} / \mathrm{mL}$, conforme instruções do fabricante.

\subsubsection{Experimentos de co-cultura}

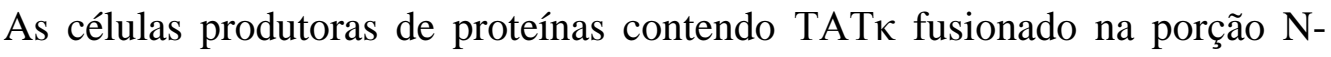
terminal dos fatores de transcrição nuclear (OCT, SOX, KLF e MYC e GFP) foram utilizadas para a co-cultura com as células-alvo, tanto MEF como fibroblastos 
humanos ou células hASC (como células alvo). As células produtoras foram plaqueadas no compartimento superior de placas com transwell de poros de 1, 3 ou 8 $\mu \mathrm{m}$ e as células receptoras no compartimento inferior, após terem sido recobertas com gelatina $0,1 \%$. O cultivo foi realizado em meio de células mES (DMEM High suplementado com 15\% de KSR, 1\% aminoácidos não essenciais, 1\% L-Glutamina, 50U/mL P/S, (todos da Invitrogen), LIF, $50 \mathrm{mM} \beta$-mercaptoetanol (Sigma)) e mantidos em uma incubadora a $37^{\circ} \mathrm{C}$ e $5 \% \mathrm{CO}_{2}$. Foram também utilizados, quando indicado, uma atmosfera hipóxica de $\mathrm{O}_{2}$ à $3 \%$ e ácido valpróico na tentativa de facilitar a reprogramação. Ambos são conhecidos por serem estimuladores da reprogramação nuclear ${ }^{82,98,99}$.

É importante ressaltar que não foi utilizado MEFs contendo gene repórter como indicador de sucesso da reprogramação (Fbox15 e Nanog). Portanto, a avaliação foi visual e, quando suspeitas, após pelo menos 20 dias, as colônias de células reprogramadas foram coletadas, expandidas e ensaiadas para atividade de fosfatase alcalina e expressão de marcadores por RT-PCR.

\subsection{Adaptação das células produtoras ao cultivo sem soro bovino}

As células produtoras de fatores nucleares eGFP das linhagens 293t e CHO foram adaptadas para produzirem proteínas em condições de ausência de soro, submetendo-as a baixas concentrações de soro de forma gradual, conforme descrito anteriormente ${ }^{100}$. O meio de cultura utilizado rotineiramente (DMEM High suplementado de $10 \%$ BCS ou 10\% FBS) foi gradualmente substituído por um meio quimicamente definido (CDM4-CHO, Invitrogen), sem soro. Todo o processo normalmente leva cerca de 40 dias para garantir a linhagem de célula a ser estável. Esta etapa contou com a colaboração da Dra. Elisabeth Pires Augusto, do "Instituto 
de Pesquisas Tecnológicas" (IPT / USP), que é especializada em cultivo de células de mamíferos em biorreatores para produção de biofármacos em grande escala.

\subsection{Análise estatística}

Os resultados foram expressos por média \pm erro padrão da média (EPM). Análises de variância de uma ou duas vias (ANOVA) com testes post-hoc do tipo Bonferroni, ou testes $t$ de Student não pareados foram utilizados para comparar grupos e tratamentos quando apropriado. Todas as análises estatísticas foram feitas usando o Software GraphPad Prism 5.0 (GraphPad Softwares Inc.,CA, USA) ou Microsoft Excel. Os gráficos de apresentação de dados em três dimensões, com respectivos EPM, foram criados usando o software MATLAB ${ }^{\circledR}$ (MathWorks Inc, MA, USA) e o script obtido da internet apresentado no Apêndice II. Valores de $\mathrm{p}<0.05$ foram considerados significativos. 
4. Resultados 


\subsection{Estabelecimento de culturas iPS/ES murinas}

O processo de cultivo in vitro das ES e, consequentemente iPS, apresentam significativas diferenças em relação às culturas tradicionais cultivadas rotineiramente no laboratório. Um primeiro aspecto é a necessidade de co-cultura com uma camada de células feeder (normalmente MEFs inativados com mitomicina ${ }^{101}$ ), que as estimula a proliferar e a manter o estado indiferenciado ${ }^{102}$. Além disso, as células murinas necessitam da presença de LIF no meio de cultura ${ }^{103,104}$ e de cuidados extensivos, com trocas de meio diárias e repique a cada 2-3 dias.

No laboratório, a Dra. Deborah Schechtman tem trabalhado com as linhagens de ES E14TG2a ${ }^{105}$ (independente de feeder, Figura 3a) e Rl-DsRED 106 (dependente de feeder, Figura 3b). Para o estabelecimento e manutenção das células reprogramadas, é fundamental ter habilidade no cultivo de células pluripotentes. Portanto, foi iniciado o cultivo de células ES, o que facilitou o reconhecimento do fenômeno de reprogramação uma vez que as células reprogramadas foram inicialmente selecionadas por aspectos morfológicos semelhantes às ES. Além disso, conforme descrito nos métodos, a $E 14 T G 2 a$ foi utilizada para se titular a produção de LIF, que foi necessário em todos os experimentos posteriores. 
A)

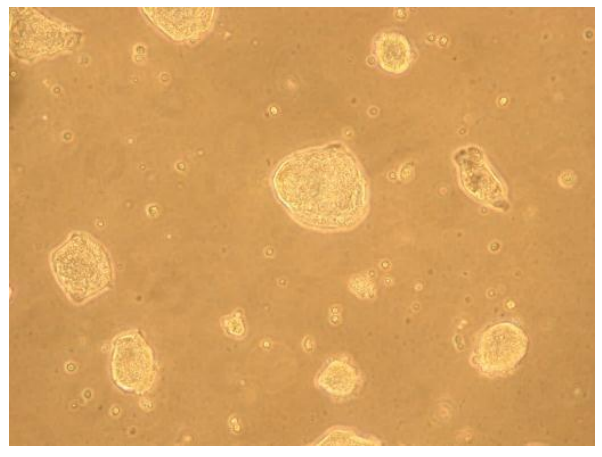

B)

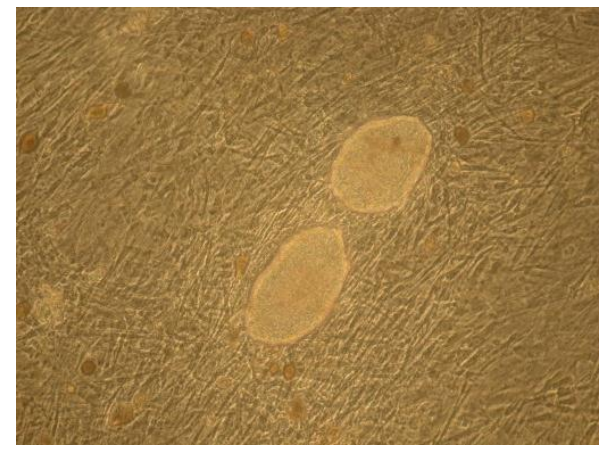

Figura 3: Imagens representativas do aspecto em cultura das linhagens (A) E14TG2a e (B) R1-DsRED.

É possível observar que as células crescem em colônias agregadas, com aspecto refringente no aumento de 100x utilizado. Ainda, as E14TG2a são cultivadas sem camada feeder, ao contrário da R1.

\subsection{Obtenção de colônias iPS murinas com retrovírus}

\subsubsection{Produção dos retrovírus $p M X$}

Iniciou-se a produção dos retrovírus vetores dos quatro fatores necessários para reprogramação de MEF em iPS (pMX-Oct, pMX-Sox, pMX-Klf e pMX-Myc). Além disto, foi feito o retrovírus para expressar o gene GFP (pMX-GFP), que foi utilizado como indicador indireto do grau de eficiência da transdução viral. Por citometria de fluxo foi possível verificar que as 293 t estavam expressando o GFP, bem como produzindo e secretando as partículas virais. NIH-3T3 e MEFs transduzidas com o retrovírus GFP expressaram o transgene em aproximadamente 60-70\% das células. Uma vez confirmada a eficiência de infecção do vírus, partiu-se para uma produção maior de vírus e iniciou-se o processo de geração das iPS.

Em um primeiro experimento, utilizaram-se MEF e NIH-3T3 como alvos de reprogramação. Contudo, mesmo após três semanas com trocas sucessivas de meio de ES, não foi possível observar colônias, apenas a proliferação maciça de células. Observou-se também que, nesse experimento, o grau de infecção das células foi demasiadamente baixo - 4,85\% em MEF e 21,46\% na NIH-3T3 (na literatura é 
reportado pelo menos $60-80 \%$ de eficiência para que o processo ocorra ${ }^{53}$ ), o que pode ter determinado a dificuldade de observar a reprogramação (Figura 4).

A)

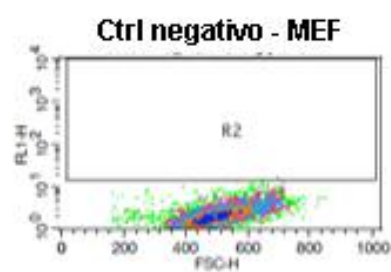

B)

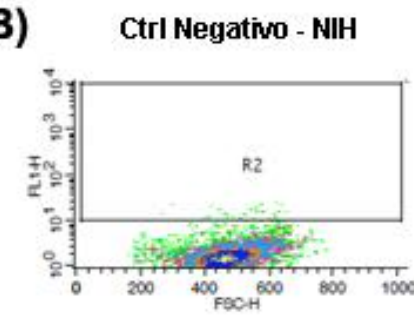

D)

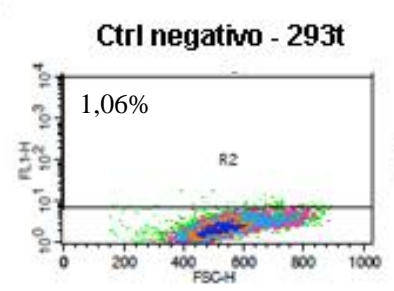

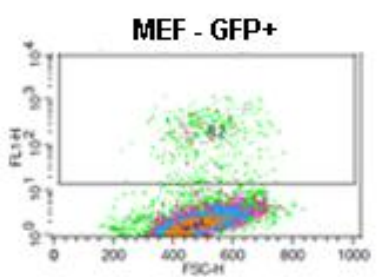

NIH - GFP+

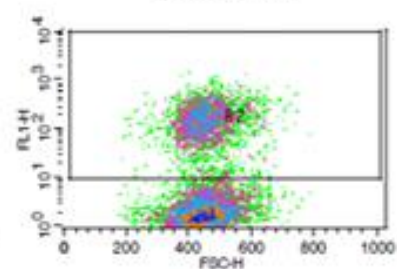

$293 t$ transfectada

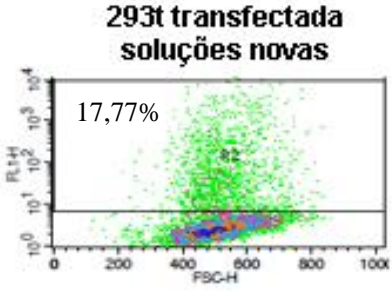

C)

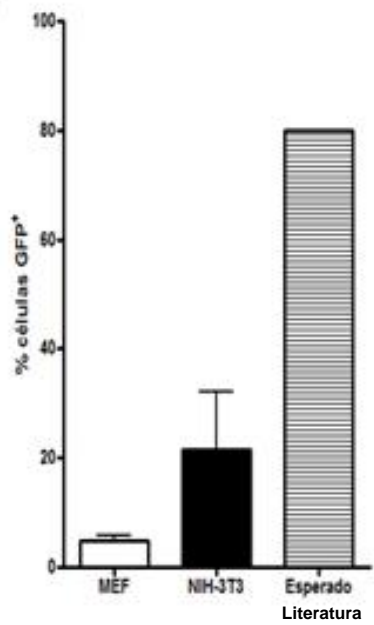

293t transfectada soluçōes antigas

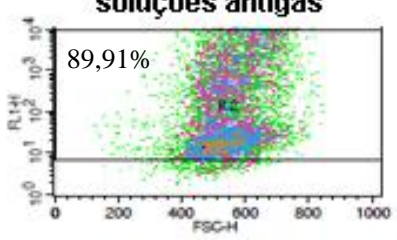

Figura 4: Density plots representativos da intensidade de fluorescência verde (GFP) versus tamanho celular (Forward Scatter, FSC) de células infectadas com retrovírus. Células MEF e células NIH-3T3 (B) foram infectadas com retrovírus obtendo-se eficiência limítrofe. Em $(\mathbf{C})$ observa-se a proporção média de infecção obtida em comparação à esperada na literatura. (D) Constatação à posteriori de que eram as células produtoras de vírus que não estavam muito bem transfectadas pelas soluções de transfecção (Cálcio/HBS recém-preparados) que tinham sido utilizadas no processo de produção viral.

Foi preparado em sequência um novo lote de vírus usando soluções de transfecção previamente testadas (Figura 5) e se obteve maior eficiência de transdução viral (aproximadamente $45 \%$ em MEF e $75 \%$ em NIH). Na sequência, procedeu-se com o experimento de geração de iPS usando apenas MEFs na passagem 2, mas em um número maior de placas de $10 \mathrm{~cm}$ para maximizar a 
possibilidade de aparecimento de colônias. Além disso, duas placas receberam infecção viral por três rounds. As células infectadas foram repicadas para se passar para a placa com feeder $\left(5 \times 10^{4}\right.$ cels por placa), e as remanescentes não foram descartadas. Foram novamente plaqueadas em plascas P100, de forma que as células que não foram reprogramadas nesse pool fizessem o papel do feeder.

A)

Verificação da transfecção 293t produtura de retrovírus
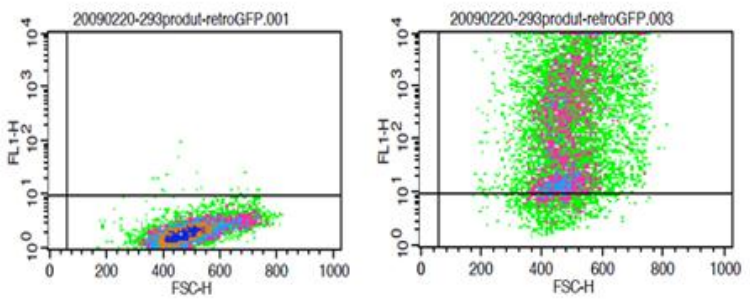

B)

Verificação de infecção - NIH-3t3
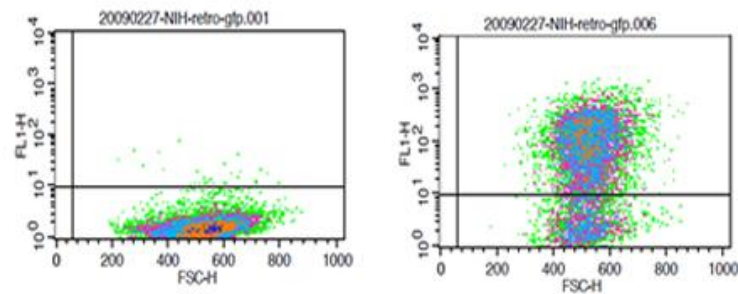

C) Verificação de infecção - MEF Passagem 3
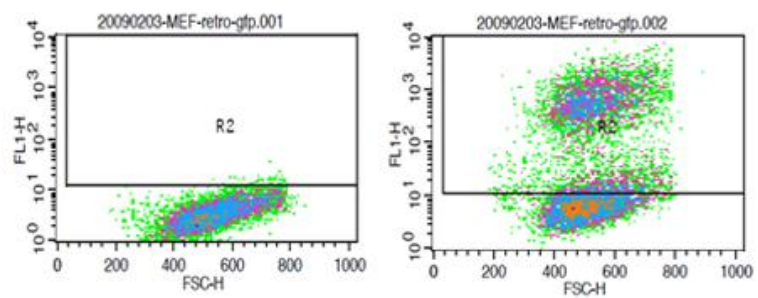

Figura 5: Density plots representativos da intensidade de fluorescência verde (GFP) versus tamanho celular (Forward Scatter, FSC) de células transfectadas para produzir vírus e infectadas de maneira a se avaliar o nível de transdução.

(A) Células 293t transfectadas para produzir partículas virais do plasmídeo pMXGFP. Os vírus produzidos foram usados para infectar células (B) NIH-3T3 e (C) MEFs. Magnitude de aproximadamente $81 \%$, $75 \%$ e $45 \%$, respectivamente, da proporção de células no gate positivo para GFP foram observadas.

\subsubsection{Obtenção das colônias}


Após aproximadamente 10-12 dias da infecção em todas as placas foi possível observar o surgimento gradual de colônias de células com morfologia distinta das células feeder. É curioso observar que muitas delas parecem se deteriorar com o passar dos dias, possivelmente por apoptose. Trocas de meio diárias foram feitas até o $30^{\circ}$ dia de cultura. Após esse período, 41 colônias foram selecionadas (Figura 6) e transferidas, usando-se um bisturi e micropipeta de $20 \mu \mathrm{L}$ no microscópio invertido, para placas de 24 poços previamente plaqueadas com feeder.

Chamou nossa atenção a diversidade morfológica que as colônias apresentam e procurou-se registrar por meio de imagens de microscopia de contraste de fase todas as colônias anotadas. Essas imagens foram posteriormente utilizadas para compor um banco de imagens, juntamente com outro experimento feito especificamente para esse propósito. A partir dele foi possível criar um sistema usando lógica Fuzzy para auxiliar na discriminação das colônias falsas das verdadeiras (Apêndice III). 


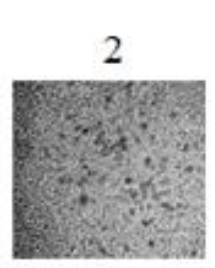

10

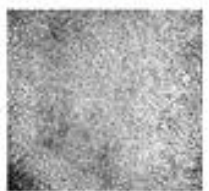

16

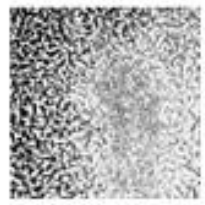

22

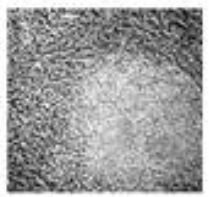

28

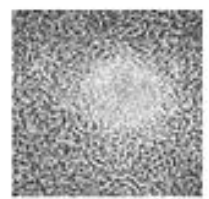

34

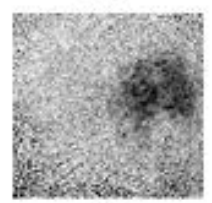

',

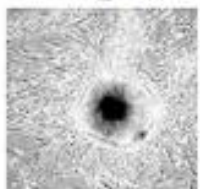

4

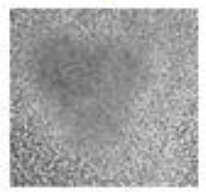

11

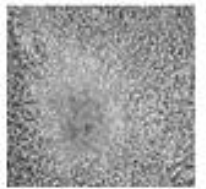

17

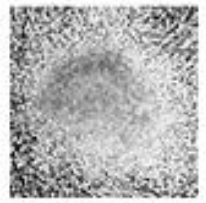

23

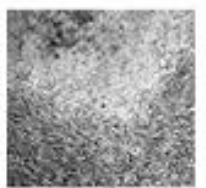

29

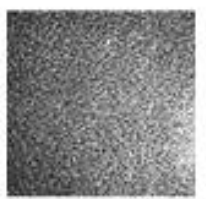

'́ñ'

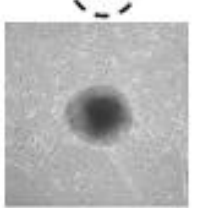

(41)

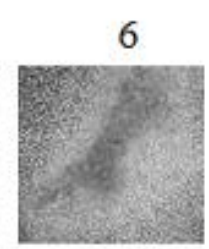

12

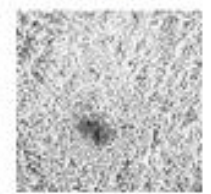

18

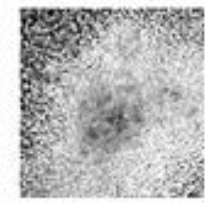

24

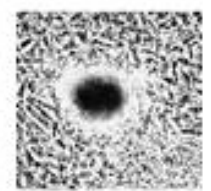

30

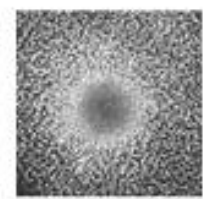

'36',
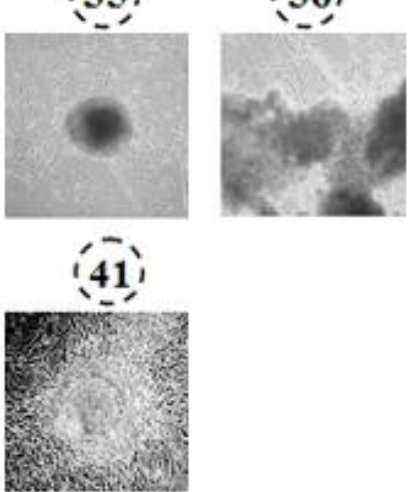

7

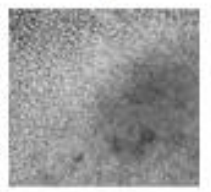

13

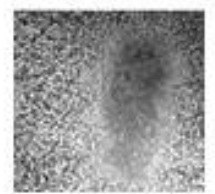

19

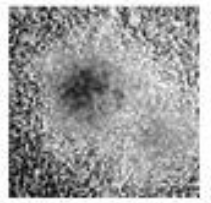

25

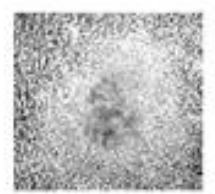

31

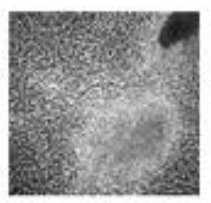

(37)

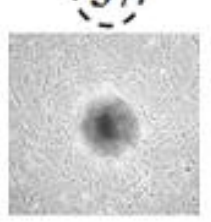

14

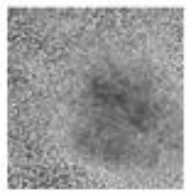

20

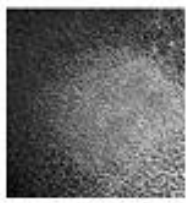

26

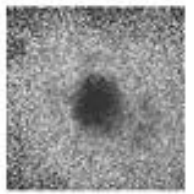

32

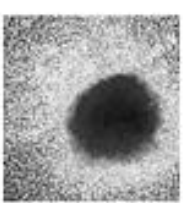

38

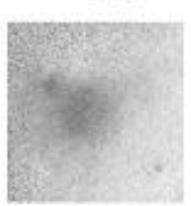

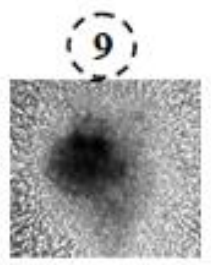

15

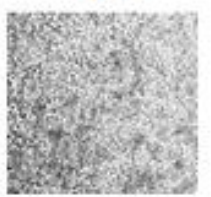

21

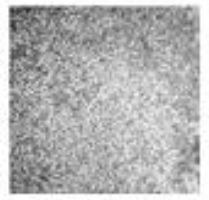

27

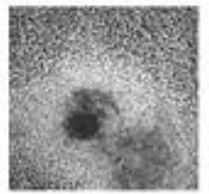

33

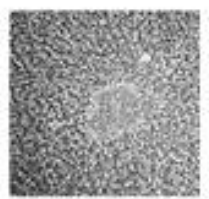

39

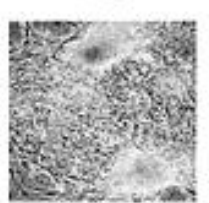

Figura 6: Imagem representativa das 38 colônias coletadas.

Trinta e oito das 41 colônias observadas em todas as placas foram coletadas com sucesso após 30 dias da infecção de Oct3/4, Sox2, Klf4 e c-Myc. As colônias positivas estão circuladas e em negrito. Números faltantes são colônias que foram perdidas no processo de transferência. Aumento de 100x. 
Em até sete dias após a transferência, foi possível observar o crescimento das colônias 9, 35, 36, 37, 40 e 41, com uma morfologia bastante distinta do feeder, e muito semelhante a ES R1-DsRED (Figura 7). As demais colônias não proliferaram após a transferência, sendo, portanto, consideradas falsas.
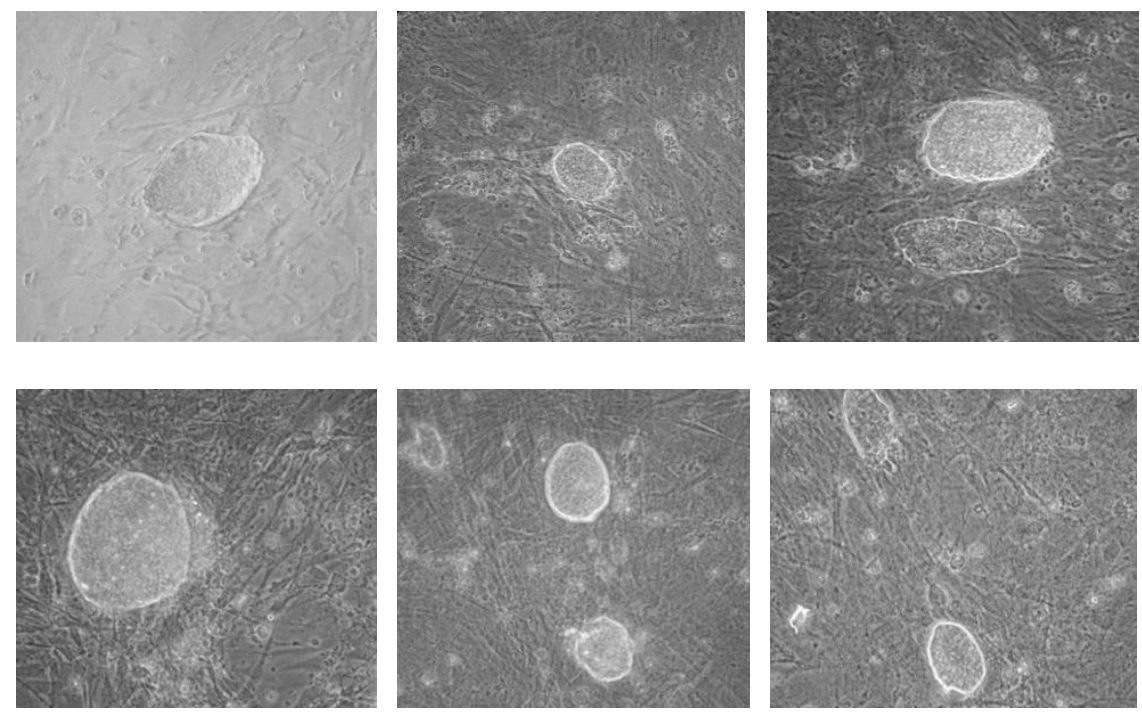

Figura 7: Imagens representativas da morfologia das colônias positivas iPS após a transferência. (Aumento 200x).

Esse experimento de infecção de células com vetores virais pMX para geração de iPS foi repetido em outras ocasiões e todas as tentativas foram compiladas em termos de eficiência de transfecção das células produtoras versus transdução dos vírus nas células MEF ou NIH-3T3. Assim foi possível gerar um gráfico de associação entre elas (Figura 8). 


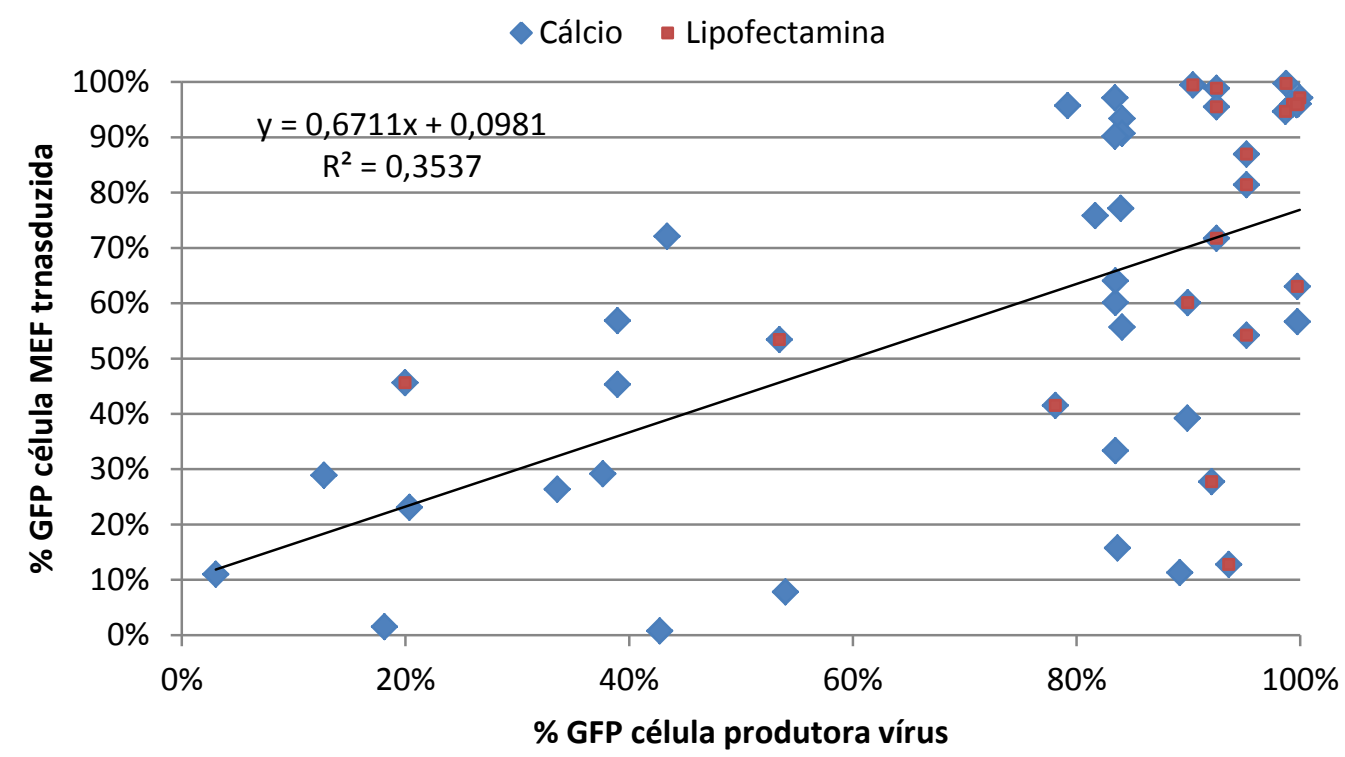

Figura 8: Células transfectadas com Lipofectamina apresentam menor variabilidade na produção retroviral.

Células 293t foram transfectadas com os plasmídeos de produção de retrovírus (anfo ou ecotrópico) usando diferentes métodos (Cálcio ou Lipofectamina) e essas produções foram usadas para transduzir células MEF.

Pode ser observado que há uma clara tendência de ser menos variável a transfecção por Lipofectamina. Além disso, de maneira geral é possível se estimar que as transfecções em 293t de eficiência menor do que aproximadamente $80 \%$ não tem grandes chances de gerar vírus o suficiente para que a transdução viral seja bem eficiente (acima de 60-80\%, conforme recomendado). Por vezes, mesmo com altos índices de transfecção não se consegue altos índices de transdução. Essa marca foi utilizada como divisor de águas nos experimentos subsequentes, de maneira a evitar o consumo desnecessário de material com experimentos de baixo índice de transdução. Além disso, para o sistema retroviral passou-se a utilizar Lipofectamina ao invés do método de cálcio. 


\subsubsection{Verificação da pluripotência das colônias obtidas}

As colônias positivas foram ampliadas e congeladas em pelo menos 2 passagens distintas. Em seguida, passou-se a realizar ensaios para verificar a pluripotência e a similaridade das colônias obtidas com ES.

Nesse sentido, dois primeiros ensaios fundamentais realizados foram a verificação de marcadores moleculares de pluripotência por RT-PCR e da atividade de fosfatase alcalina das células (Figura 9). Todas as colônias testadas apresentaram atividade de fosfatase alcalina e expressão positiva para os marcadores de pluripotência (Eras, Esg, Rex1, Klf4, Oct3/4 e Sox2).

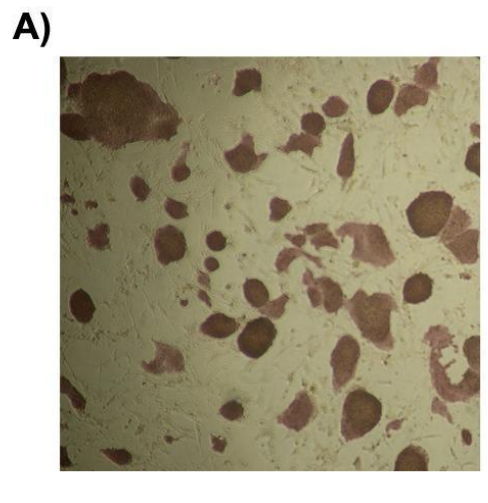

C)

B)

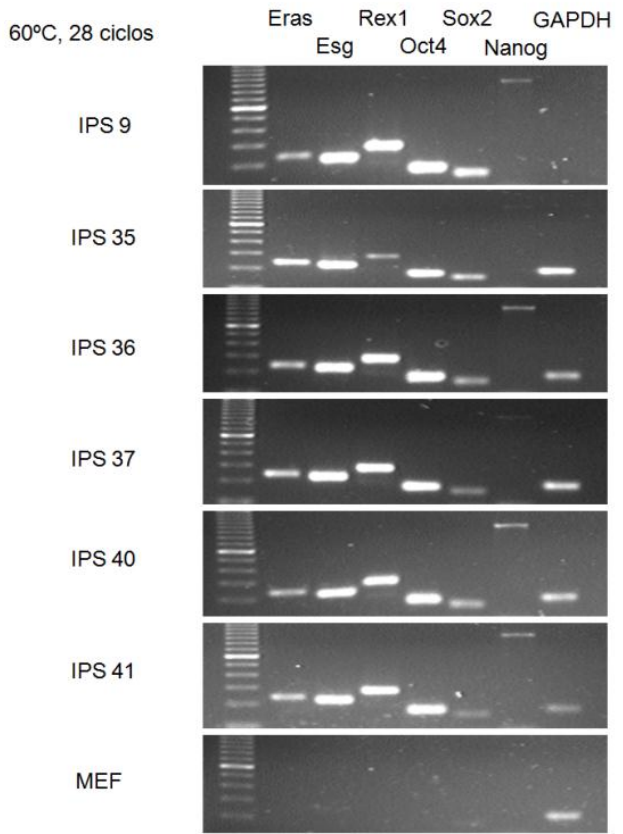

Figura 9: Imagens representativas da verificação da presença da atividade de fosfatase alcalina

Aumento de (A) 100x e (B) 400x. Todas as colônias testadas apresentam marcação positiva (coloração em marrom) em 6 diferentes colônias de iPS. (C) Verificação de marcadores moleculares de pluripotência por RT-PCR. 
Dando continuidade aos experimentos de caracterização das células iPS derivadas de MEF, foi realizada a verificação por imunofluorescência do marcador de superfície SSEA-1 (Figura 10). Esses resultados demonstram a semelhança dessas células com as ES.
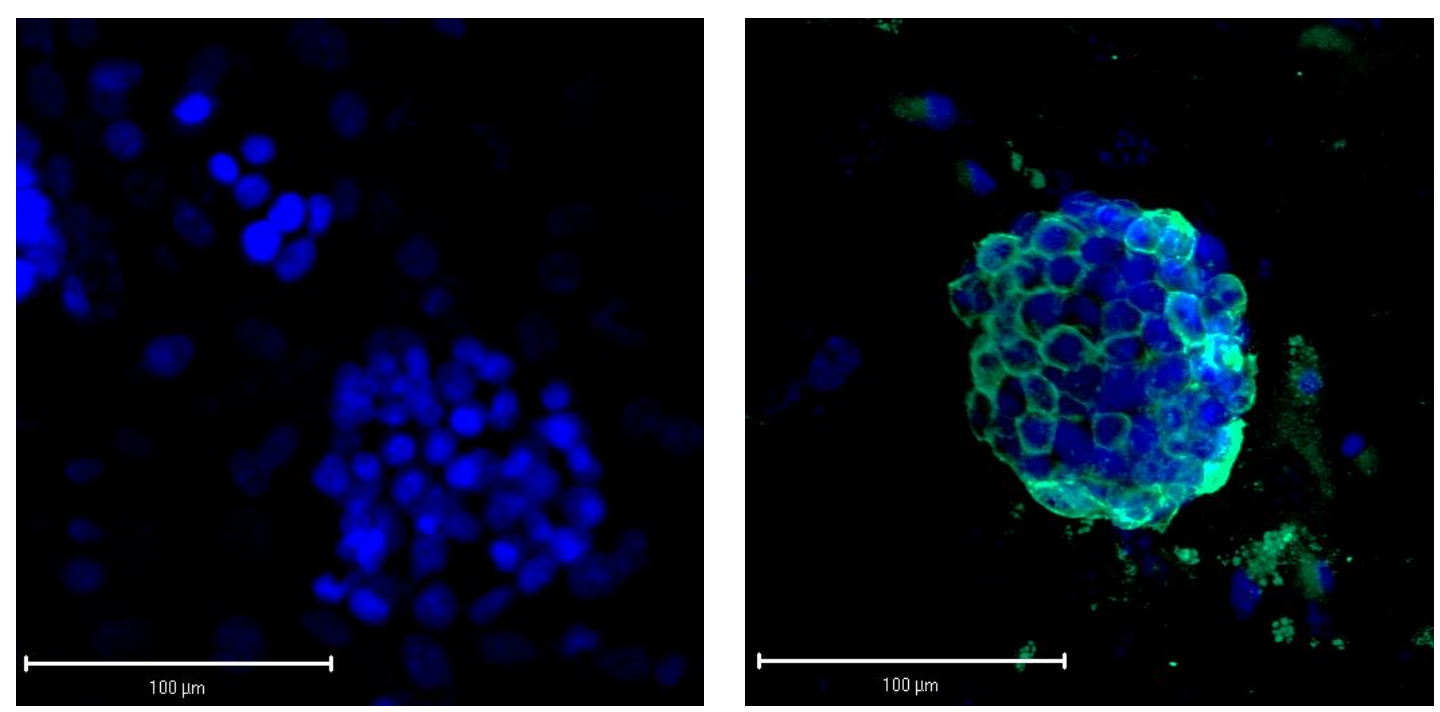

Figura 10: Caracterização das mIPS por imunofluorescência com microscópio confocal para SSEA1.

Imagens representativas na ausência (esquerda) e na presença (direita) do anticorpo anti-SSEA1 no ensaio. Esse é um marcador de superfície comumente encontrado em células mES e está presente nas iPS derivadas no laboratório (aumento de 200X).

Procedeu-se, em seguida, com a injeção das células iPSs em animais nude com o objetivo de observar a formação de teratomas. Esta análise possibilitou observar a formação de estruturas derivadas dos três folhetos embrionários (ectoderma, mesoderma e endoderma; Figura 11), o que demonstra a pluripotência destas células. Todas as colônias testadas demonstraram capacidade de formar estruturas dos três folhetos embrionários, sendo encontradas estruturas semelhantes à pele e tecido nervoso (ectoderma); ao tecido adiposo, músculo liso e estriado, tecido linfático, cartilagem e trabécula óssea (mesoderma); glândulas serosas e mucosas, 
parótida, epitélio respiratório e cúbico simples ciliado e intestino (endoderma). Com isto, fica confirmado que as colônias selecionadas são pluripotentes.
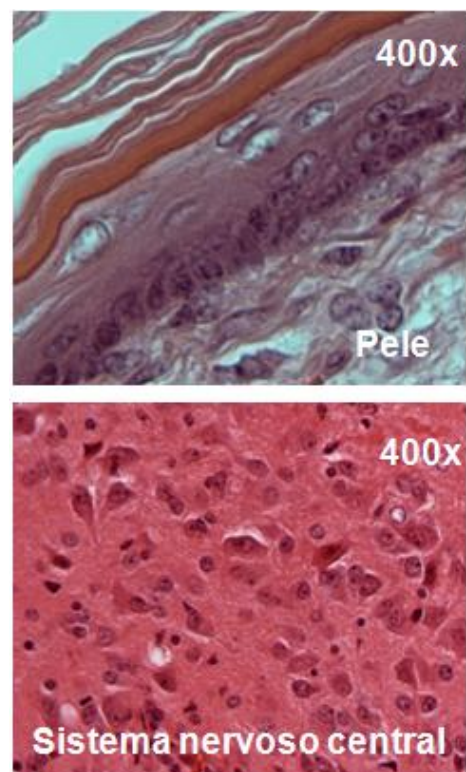

Ectoderma
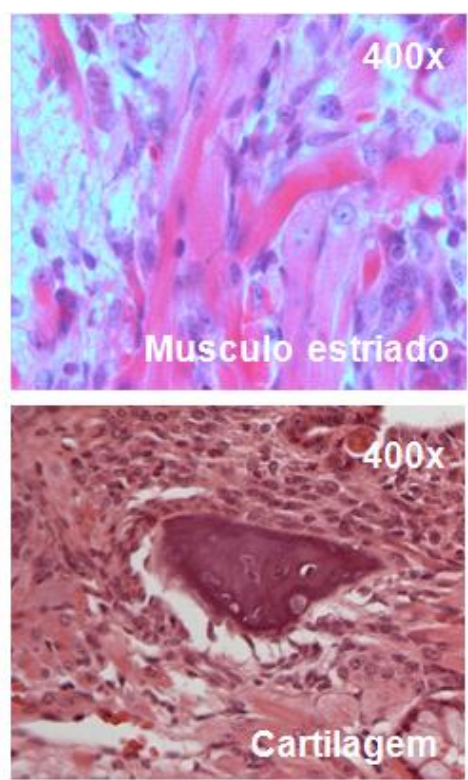

Mesoderma
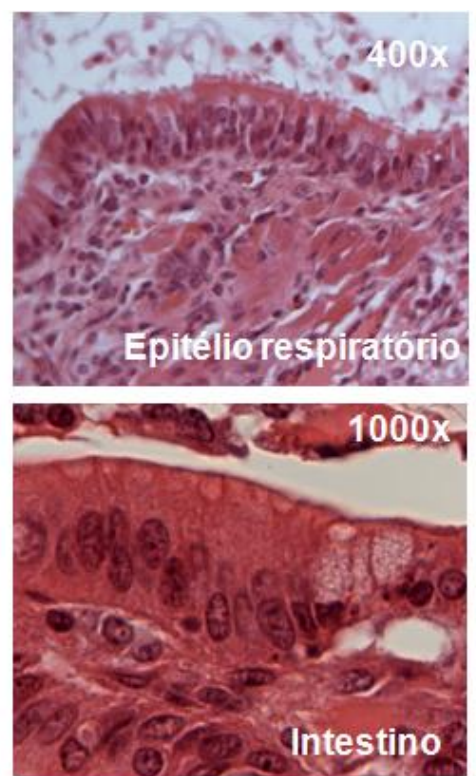

Endoderma

Figura 11: Verificação da formação de estruturas derivadas dos três folhetos embrionários em teratomas em animais Nude por coloração HE. Os aumentos utilizados estão indicados.

Na sequência, procedeu-se com um ensaio padrão-ouro de determinação de pluripotência das iPS - a geração de animais quiméricos. Para tanto foram infectadas as iPS da colônia 40 com lentivírus carreando a proteína GFP em alta titulação, obtendo-se uma população aproximadamente $80 \% \mathrm{GFP}^{+}$(Figura 12a e 12b). Em seguida, essas células foram injetadas em blastocistos de camundongo, que, após cinco tentativas, conseguiu-se gerar um feto quimérico (Figura 12c). Portanto, a cultura de iPS murina foi plenamente estabelecida e caracterizada no laboratório. 
A)

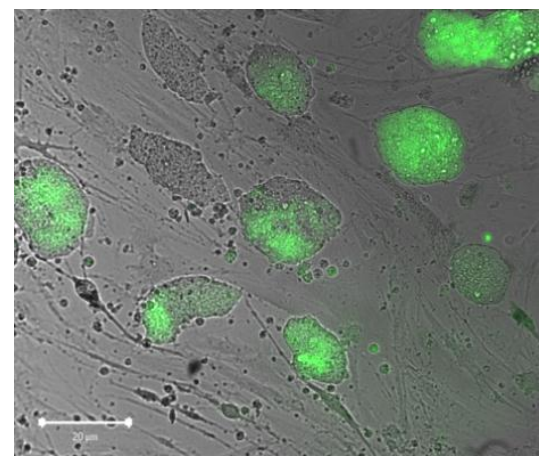

C)

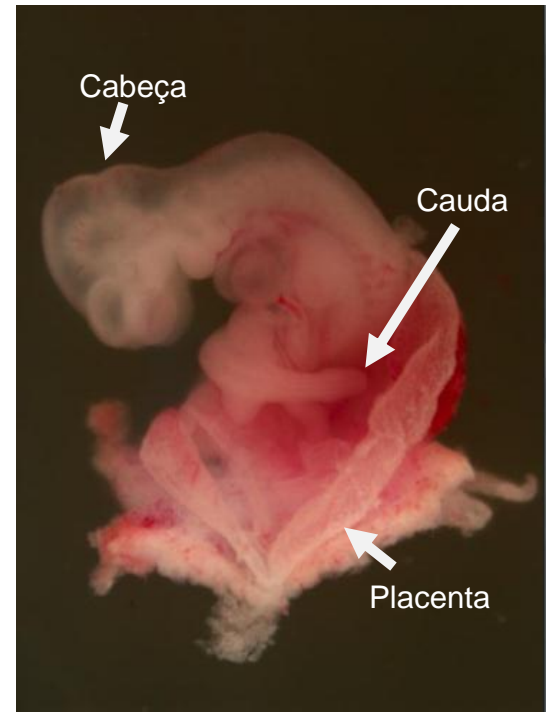

B)

iPS 40P13 GFP+
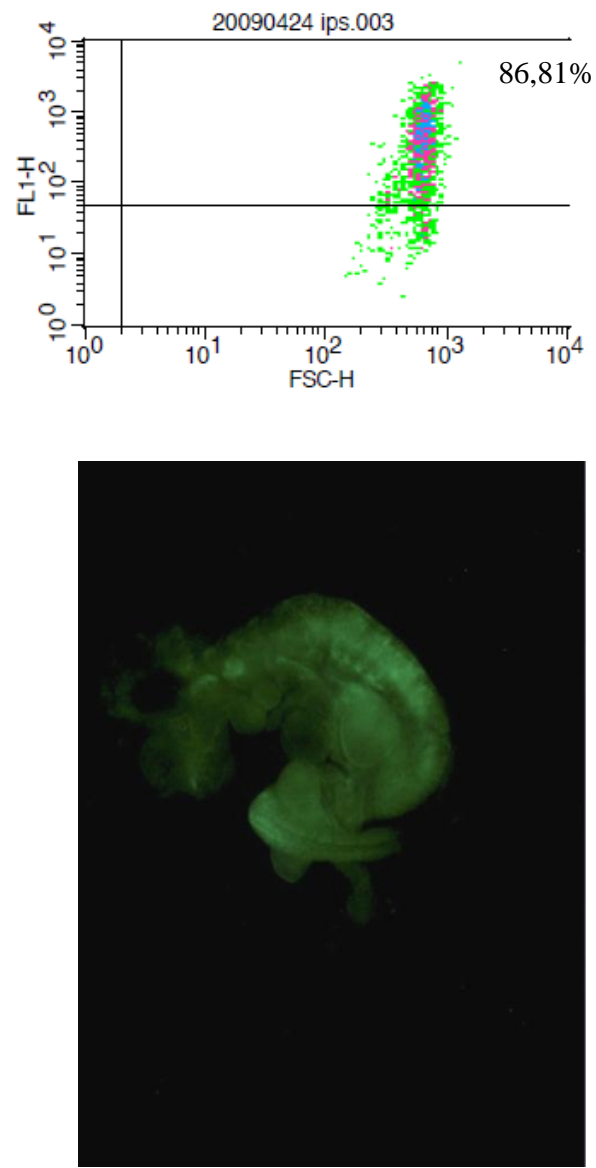

Figura 12: Geração de animal quimérico a partir de iPS.

(A) Visualização por microscopia de fluorescência da colônia 40 infectada com GFP (aumento de 100x). (B) Determinação por citometria de fluxo da proporção de células que foi eficientemente infectada pelo lentivírus. (C) Feto de camundongo quimérico em E10 visualizado em lupa (à direita com filtro para GFP). É possível observar que praticamente todo o corpo do embrião está fluorescente, inclusive o coração e os membros em desenvolvimento (Aumento de 20x).

Também se procurou verificar as diferenças de tamanho entre as colônias obtidas com 4F (OSKM) e 3F (OSK) e promover a diferenciação das iPS nas células do fenótipo vascular (endotelial, muscular lisa e cardíaca) tanto como prova do princípio como por suas futuras aplicações que terão no laboratório. Os métodos in vitro que são utilizados nas ES funcionam bem também nas iPS 107, 108 . Esses resultados estão apresentados no Apêndice I. 


\subsection{Obtenção de colônias iPS humanas com lentivírus}

\subsubsection{Sistema pSin}

De maneira análoga à reprogramação de células murinas, procurou-se reprogramar células de humanos para que houvesse o aprendizado do processo, da identificação de sua morfologia e que elas servissem de células modelo para comparação em relação às células que seriam reprogramadas usando o sistema sem vírus. Não havia na literatura a descrição de reprogramação de células mesenquimais de tecido adiposo e escolheu-se realizá-la, em detrimento dos fibroblastos, utilizando o sistema lentiviral pSin-EF2-Pur codificando OCT3/4 ou SOX2 ou NANOG ou Lin28 ou GFP publicado por Yu e colaboradores ${ }^{55}$. Isso se deve ao fato de que em ensaios preliminares no laboratório, observou-se que as hASC não são bem infectadas com retrovírus anfotrópico. Num primeiro ensaio procurou-se verificar qual seria o melhor plasmídeo de empacotamento lentiviral para infecção de hASC (Figura 13), utilizando-se o GFP como backbone e a análise de eficiência realizada por citometria de fluxo. 
A)
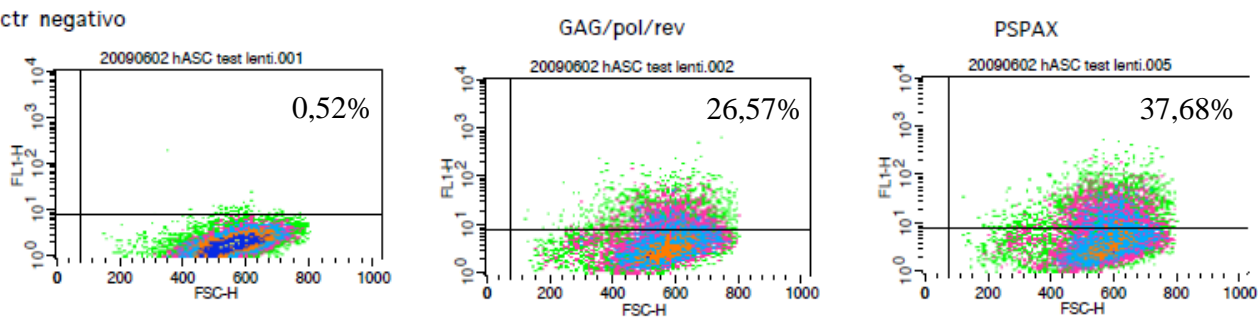

B)
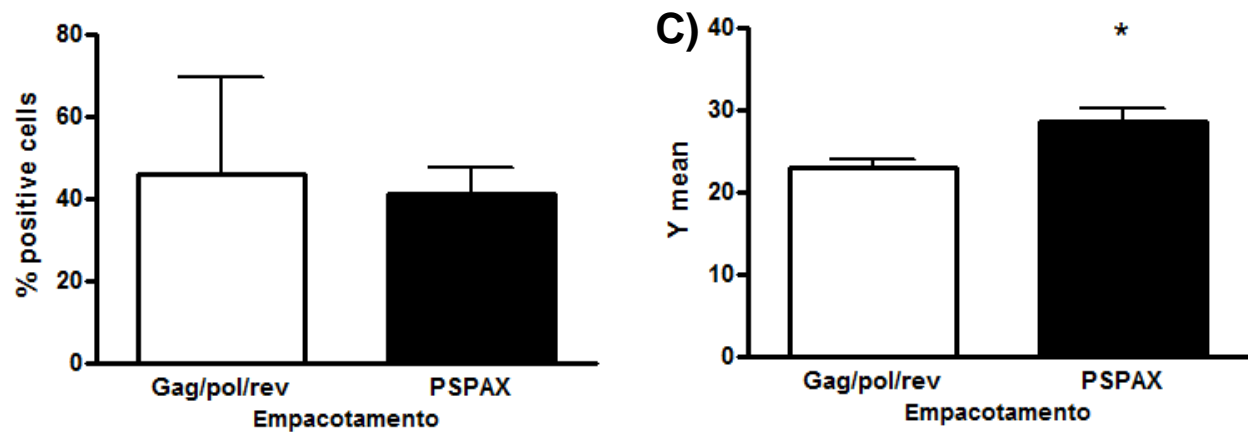

D)

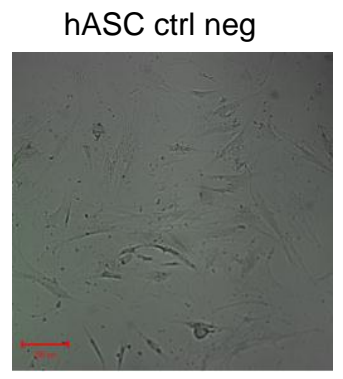

hASC 59 passagem 2

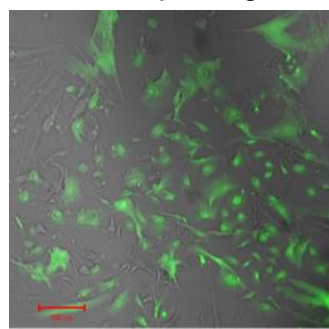

Figura 13: Verificação do melhor empacotamento lentiviral para infecção de hASC $(\mathrm{N}=3)$.

(A) Imagens representativas dos densitiy plots para GFP VS. FSC. A \% de células $\mathrm{GFP}^{+}$teve maior variabilidade no empacotamento gag/pol/ver. Quantificação da (B) proporção de células positivas e da $(\mathbf{C})$ intensidade média de fluorescência (MFI) do gate positivo de 3 experimentos com células de pacientes diferentes, mas a partir de um mesmo lote de produção de vírus. (D) Imagem representativa do taxa de infecção das células mesenquimais de tecido adiposo pelo lentivírus GFP (Aumento de 100x).

Aparentemente tanto o plasmídeo expressando GAG/pol/rev como psPAX geraram populações infectadas com a mesma proporção, Contudo, como PSPAX fez com que as células ficassem, em média, mais fluorescentes, esse empacotamento foi escolhido para os experimentos subsequentes.

Na sequência, foram efetuadas três tentativas de reprogramação das hASC. Em algumas ocasiões se observou a formação de colônias, contudo não foi obtido 
sucesso na reprogramação. Em todas as ocasiões, após serem passadas para o feeder, nenhuma colônia com morfologia semelhante às hES emergiu em até 21 dias. Hipotetizou-se que o tipo celular pudesse ser um problema e passou-se a utilizar fibroblastos de pele de prepúcio humano ao invés de hASC. Depois de infectadas, foi aguardada a reprogramação, com trocas diárias de meio de iPS contendo FGF-2 (Figura 14).
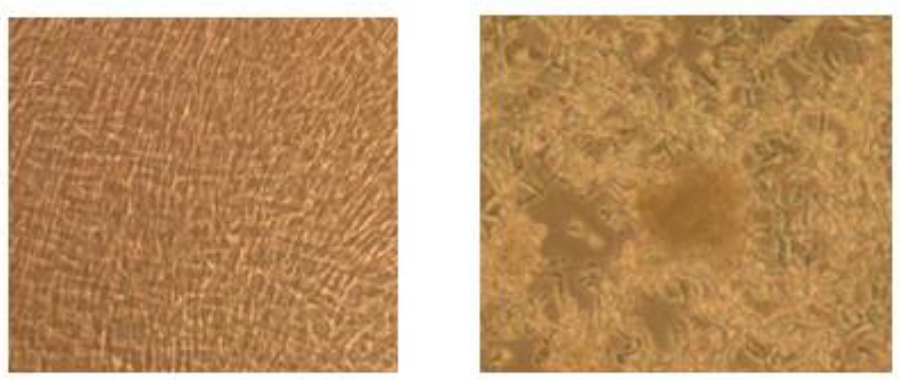

Figura 14: Imagem ilustrativas das colônias hiPS a partir de fibroblastos.

Após 30 dias da transdução dos lentivírus em fibroblastos humanos, 72 colônias semelhantes à apresentada na figura da direia emergiram e foram coletadas. Entretanto, nenhuma colônia proliferou (Aumento de 100x).

Nesse período, foi publicada a possibilidade de reprogramação de células mesenquimais de tecido adiposo humano ${ }^{109}$, inclusive sem a necessidade de feeder, o que sugere que é sim possível reprogramá-las. Com isso voltou-se a trabalhar com as mesenquimais de tecido adiposo, principalmente pela facilidade na obtenção de material que nosso laboratório possui. O processo de infecção foi repetido mais quatro vezes, e todas as tentativas foram perdidas por contaminação por leveduras. Assim que o problema das contaminações foi resolvido, passou-se a fazer ciclos de infecção semanal e passagem para o feeder. A partir desse momento passou-se a utilizar o ácido valpróico $(0,5 \mathrm{mM})$ e as células infectadas foram mantidos sob em uma atmosfera de hipóxia $\left(3 \% \mathrm{O}_{2}\right)$. Seis novas tentativas foram feitas nessa nova condição, a partir de diferentes lotes de produção de vírus. No primeiro, obtiveram-se 
apenas $5 \%$ de infecção utilizando $10 \mu \mathrm{L}$ do concentrado de cada vírus e o material foi descartado. No segundo, foram realizados três ciclos de infecção em células aderidas e foram obtidas em torno de $28 \%$ de taxa de infecção e, elas foram posteriormente transferidas para uma placa com feeder. Após 30 dias, colônias grandes, com aspecto tridimensional e forma arredondada estavam bem evidentes e foram coletadas e plaqueadas em placas de 6 poços (Figura 15A). No entanto, apesar de serem cultivadas por mais 15 dias após coletadas, elas não cresceram, o que sugere ser uma colônia falsa de hiPS.

$\mathrm{Na}$ terceira tentativa, depois de dois ciclos de infecção em suspensão, utilizando-se $10 \mu \mathrm{L}$ para cada vector lentiviral, foram obtidas $\sim 66 \%$ de células verdes. Essas células, cultivadas por 30 dias, também geraram algumas colônias. Eles foram coletadas e postas para expandir em uma placa de 6 poços com feeder (Figura 15B). No entanto, mais uma vez, as colônias coletadas não cresceram.

A)
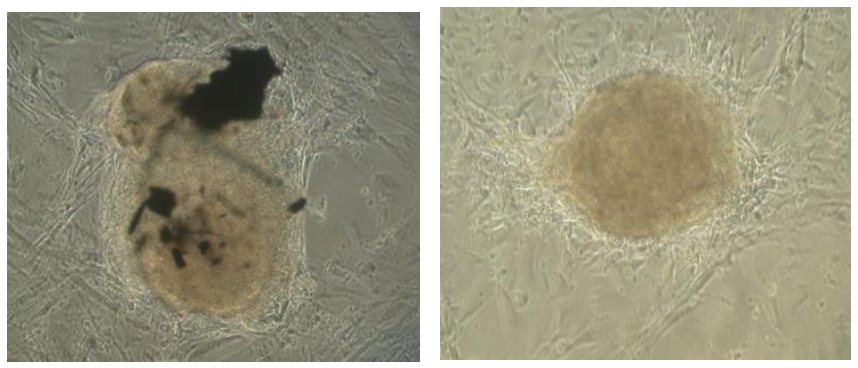

B)
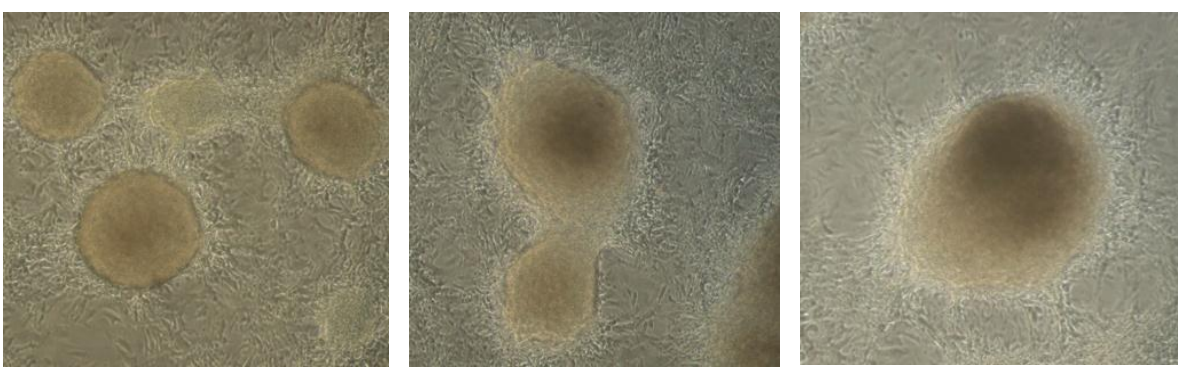

Figura 15: Formação de colônias hIPS depois de 18 dias desde a infecção. Imagens representativas das colônias da (A) segunda e (B), terceira tentativa de reprogramação (Aumento de 100x.). 
A partir desse ponto, procurou-se aumentar a taxa de infecção, pois, se considerando que os quatro genes estavam em vetores independentes, a probabilidade de sucesso seria maior quanto mais alta fosse a taxa de infecção. Numa quarta tentativa, procurou-se aumentar o número de infecções cíclicas em suspensão por até oito vezes, contudo as células sofreram e acabaram morrendo.

$\mathrm{Na}$ sequencia, um teste com o vírus GFP apenas foi feito a partir de duas produções de vírus independentes, com a intenção de usar mais de $10 \mu \mathrm{L}$ de concentrado de vírus para a infecção (na tentativa de aumentar o MOI; Figura 16). E ficou evidente que é possível aumentar a taxa de infecção quando é aumentado o volume de vírus. No entanto, o que aparentemente estava sendo a principal fonte de variação eram os diferentes lotes de produção. Ainda que eles tenham sido feitos todos da mesma maneira, dependendo do lote de produção foram obtidas diferentes quantidades de vírus.
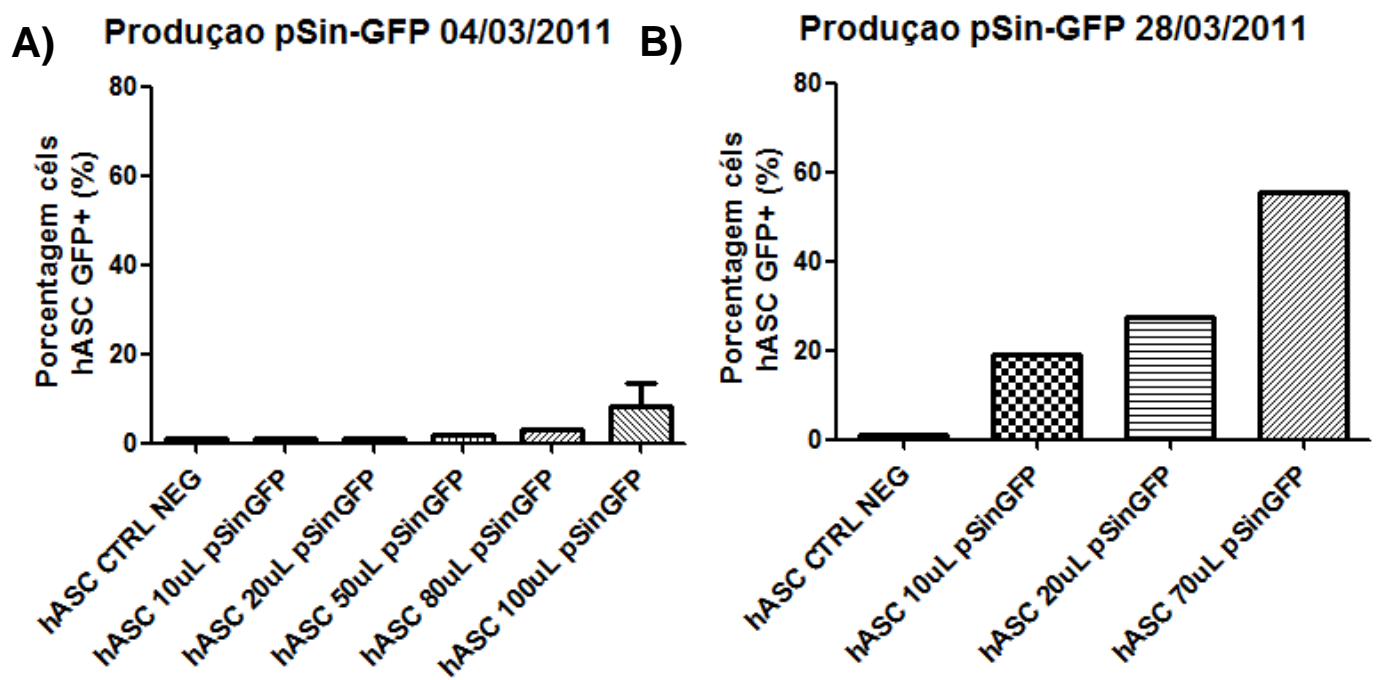

Figura 16: Eficiência de infecção varia de acordo com lotes de produção.

Com essa informação, foi realizado um sexto experimento utilizando-se $50 \mu \mathrm{L}$ de concentrado de vírus e obtendo-se a taxa de $85 \%$ de infecção. Contudo, 
novamente não foi possível coletar colônias prósperas. Levantando-se a hipótese de que pudesse estar havendo algum problema em algum dos plasmídeos e com a perspectiva de se utilizar os mais modernos sistemas lentivirais que vinham sendo publicados, contendo repórteres para os genes, abandonou-se o $p \operatorname{Sin}$ e passou-se a dois novos sistemas.

\subsubsection{Sistema lentivírus coloridos}

O primeiro dos novos sistemas a serem testados foi o conjunto de plasmídeos que codificam os quatro genes principais (OSKM) ligados a um peptídeo 2A a um gene fluorescente (respectivamente vexGFP, Citrine, mCherry e Cerulean) ${ }^{79}$. Dessa forma, seria possível avaliar por citometria de fluxo para cada plasmídeo qual seria o seu nível de expressão nas células.

Após a verificação de que o plasmídeo não apresentava problemas elementares em sua sequência por ensaio de restrição (dados não mostrados), foram realizado quatro experimentos independentes de infecção em células hASC e um experimento em células NIH3T3, utilizando-se $50 \mu \mathrm{L}$ do volume de vírus, por condição. Todos apresentaram um nível de infecção variando de 5 a $35 \%$ para os vírus carreando OCT e SOX e de no máximo $10 \%$ para os vírus KLF e MYC (Figura 17A). Ao se verificar a associação desses índices com o nível de transfecção (Figura 17B), conforme foi realizado com os retrovírus anteriormente. Como resultado observa-se que para os vírus OCT e SOX há uma alta taxa de transfecção, ao contrário de KLF e MYC, que ajuda a entender porque da disparidade. Procurouse também verificar se seria possível coletar os vírus por vários dias seguintes acompanhando-se o nível de expressão de SOX-Citrine (em termos de porcentagem de células marcadas e MFI; Figura 17C) e pode ser observado que ainda que as 
células se mantenham marcadas por até sete dias, a quantidade de fluorescência decai exponencialmente, inviabilizando coletas de vírus por períodos maiores do que $48 \mathrm{~h}$.

A)

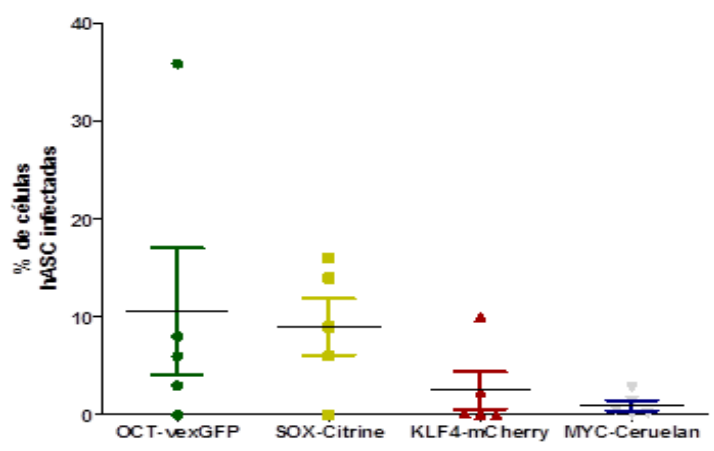

B)
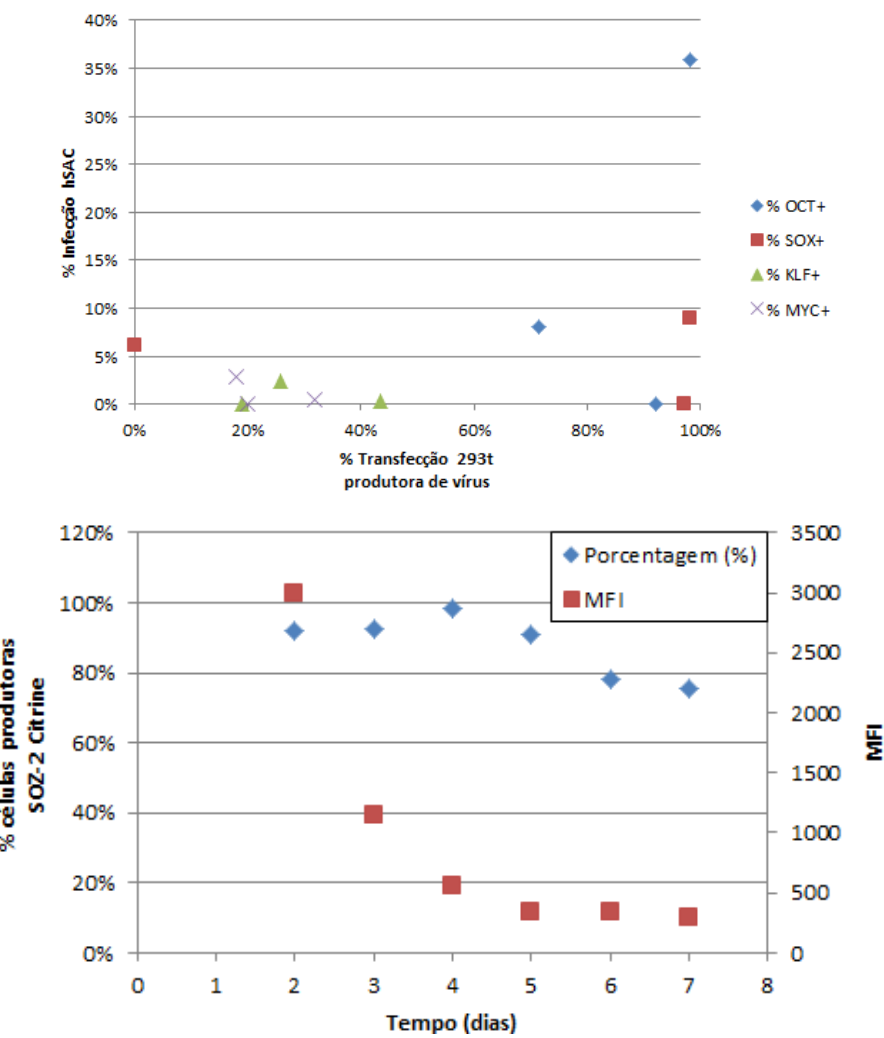

Figura 17: hASC eficiência de infecção varia de acordo com lotes de produção.

(A) Taxa de infecção de células hASC (B) associação entre taxa de infecção de hASC e ao porcentagem de transfecção das células produtoras de lentivírus e (C) acompanhamento em função do tempo da porcentagem de células transfectadas e da intensidade de fluorescência média, que indica o conteúdo de proteínas fluorescentes na célula

Esses índices são considerados insuficientes para a reprogramação, pois é muito raro acontecer nessas condições a co-infecção dos quatro virus. Seria possível 
tentar melhorar as condições de transfecção para melhorar esses índices, contudo preferiu-se concentrar esforços no terceiro sistema lentiviral, que apresenta OSKM no mesmo plasmídeo e é suficiente para resolver a limitação que o sistema de lentivírus colorido apresenta.

\subsubsection{Sistema STEMCCA}

O terceiro sistema lentiviral utilizado foi o com plasmídeo policistrônico (pHAGE-hSTEMCCA), publicado por Mostoslavsky e colaboradores ${ }^{92}$. Ele é composto de três plasmídeo independentes: um permite a expressão de três fatores nucleares (OCT, SOX, e KLF) e um marcador fluorescente vermelho (RED) em uma mesma célula, o outro tem um promotor induzível Tet-on (para OSKM) e o último apresenta uma sequência $\operatorname{Lox} P$ flanqueando os genes OSKM, permitindo removê-los do genoma, caso desejado.

Foram realizadas seis tentativas em células hASC com esse sistema, a maior parte com algum problema principalmente na transfecção, que rendeu uma baixa titulação de vírus. Por ser um plasmídeo de tamanho elevado, a eficiência de transfecção é naturalmente menor. $\mathrm{Na} 7^{\mathrm{a}}$ tentativa conseguiram-se colônias, contudo elas foram perdidas no processo de coleta. Em uma $8^{\mathrm{a}}$ tentativa, a partir de fibroblastos de pele (que são mais bem infectados pelos lentivírus do que as mesenquimais), foi realizado um experimento onde se variou a transfecção (por cálcio com choque de glicerol ou por lipofectamina), e a quantidade de vírus na reprogramação (1, 10 ou $50 \mu \mathrm{L}$ de concentrado de vírus) e não foi usada tripsina durante a coleta, para evitar formar células únicas. Após aguardar 20 dias, várias colônias apareceram e foram coletadas ao todo 48 de quatro diferentes condições de

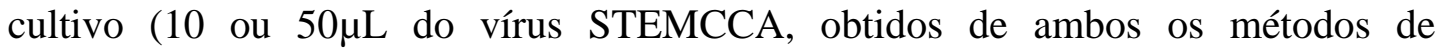


transfecção). As células da condição de $1 \mu \mathrm{L}$ de vírus cresceram muito e se soltaram da placa. Dessas placas, conseguiu-se finalmente com que 12 colônias vingassem, apresentando a característica morfologia achatada (e bastante diferente das células miPS que foi apresentada anteriormente).
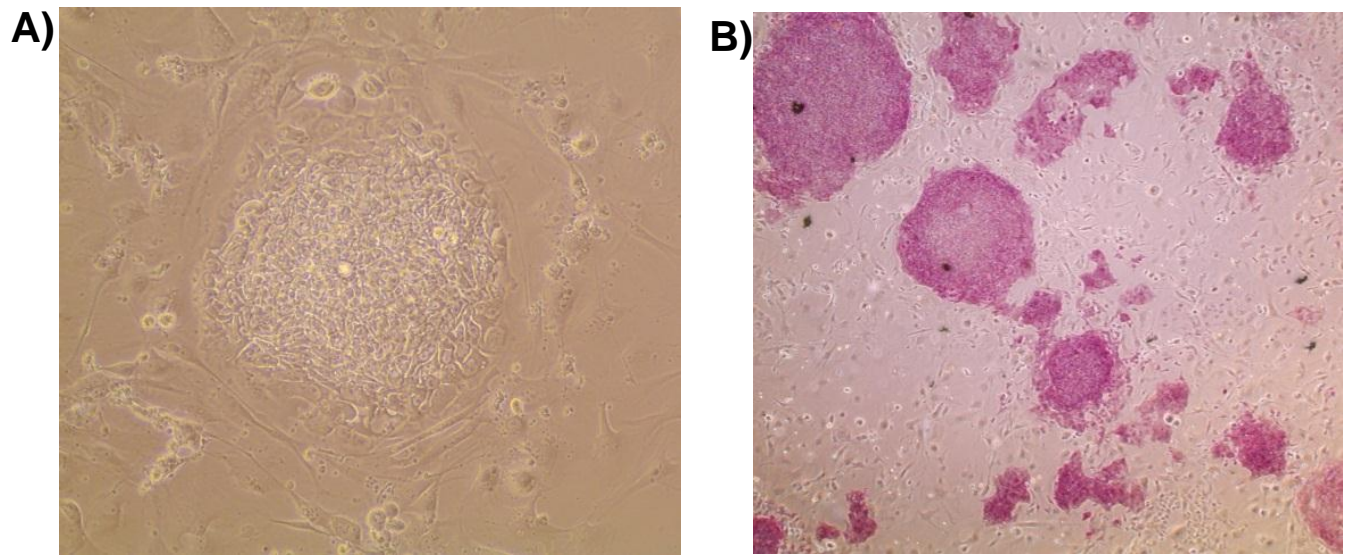

Figura 18: Imagens representativas das colônias de hiPS sob contraste de fase, após expansão.

(A) Fibroblastos de pele humanos foram reprogramados ao estado pluripotente utilizando-se do sistema lentiviral hSTEMCCA. Aumento 200x (B) Após revelação de atividade de fosfatase alcalina, aumento 100x.

\subsection{Desenvolvimento do sistema TAT-fator - Plasmídios pCL-TAT-fator-SN}

Em paralelo à geração de células iPS pelo sistema de retrovírus, iniciou-se o processo de desenvolvimento do sistema TAT-fator.

Os dois primeiros plasmídeos retrovirais a serem clonados com sucesso foram o pCL-TAT-GFP-SN e pCL-TAT-SOX-SN. Num primeiro momento se procurou verificar se eles estavam sendo transcritos adequadamente nas linhagens produtoras NIH-TAT-fator selecionadas com geneticin, portanto foi realizado RT-PCR (Figura 19). 


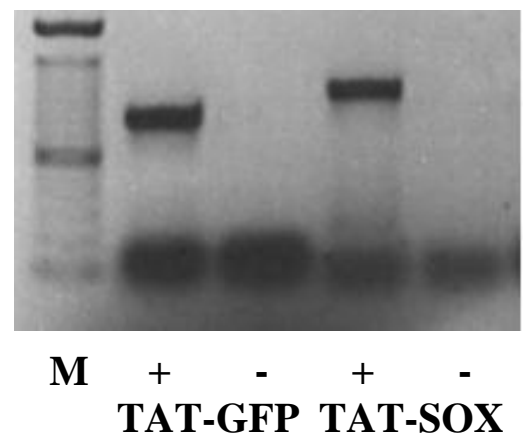

Figura 19: RT-PCR de linhagens NIH-3T3 infectadas com retrovírus para expressar TAT-GFP, TAT-SOX.

Elas foram denominadas respectivamente retroNIH-TAT-GFP e retroNIH-TATGFP. Reações utilizando como primer forward o IgKappa-F (para todas) e como reverso o primers espefícios de cada gene.

$\mathrm{Na}$ sequência, partiu-se para experimentos de verificação da expressão de TAT-GFP pelas células produtoras retroNIH-TAT-GFP por citometria de fluxo (Figura 20a). Curiosamente, observou-se que apesar da seleção de células resistente ao geneticin (evidenciada pela morte de todas as células tratadas com antibiótico, mas que não foram transduzidas pelos retrovírus, em uma placa controle, em paralelo), apenas uma pequena parte da população estava significativamente verde. Além disto, não foi possível detectar a proteína TAT-GFP no sobrenadante por meio do fluorímetro (Figura 20b). Apesar de positivo no RT-PCR, o pequeno número de células positivas para GFP possivelmente não está secretando quantidade suficiente de proteínas que possam ser detectadas no sobrenadante. Nesse experimento foi incluído, como controle positivo a proteína recombinante 500nM TAT-GFP e também o anticorpo Alexa488 ${ }^{\circledR}$, diluídos em meio de cultura. 


\section{A) Controle negativo}

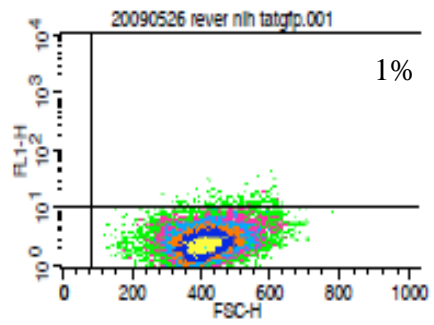

B)

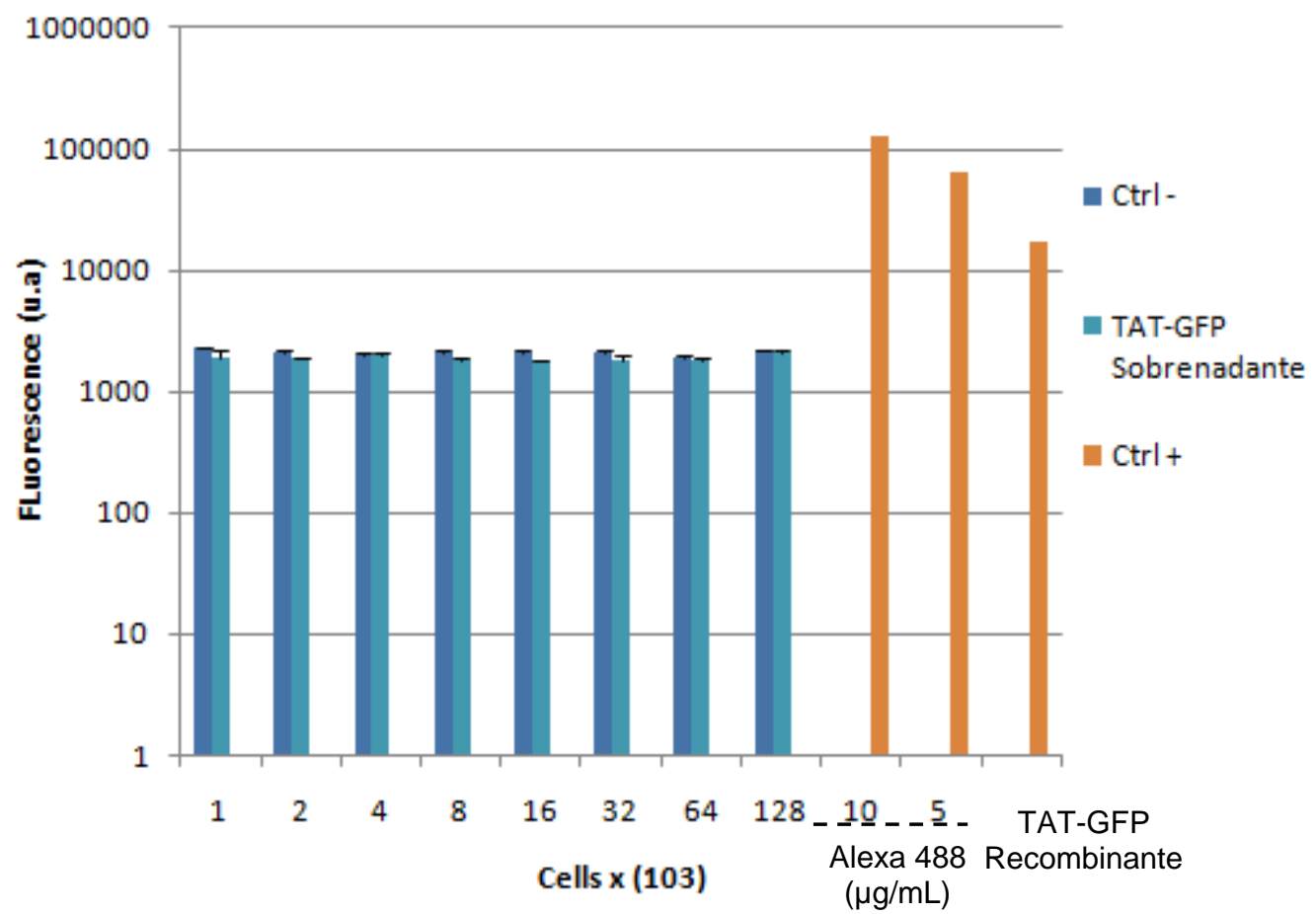

Figura 20: Verificação da expressão de GFP por células transduzidas com retrovírus pCL-TAT-GFP-SN.

(A) Por citometria de fluxo, determinou-se que apenas aproximadamente $4 \%$ das células ficam verdes após transdução retroviral. Essa proporção passa para apenas $12 \%$, após um mês sob pressão seletiva de geneticin. (B) A proporção de células $\mathrm{GFP}^{+}$(mesmo selecionadas) é insuficiente para produzir um meio condicionado (DMEM sem fenol RED, 72h) com TAT-GFP de maneira detectável no leitor de fluorescência.

controle negativo: meio sem fenol RED condicionado com célula não transduzida; controles positivos: meio sem fenol RED contendo 10 ou $5 \mu \mathrm{g} / \mathrm{mL}$ de anticorpo Alexa 488 e 500nM de TAT-GFP recombinante produzido em bactérias. Observar que dados estão em escala logarítmica.

Hipotetizou-se então que se a quantidade de DNA fosse aumentada na transfecção da 293t (produtora de vírus), poderia haver maior eficiência de transfecção e consequentemente maior produção de partículas virais para transdução de NIH (produtora de TAT-fator). Alternativamente, poderia estar ocorrendo algum 
processo de degradação do transgene no proteossoma. Para verificar essas hipóteses, foi realizada uma curva de DNA em um novo ensaio de transfecção das células produtoras de vírus e, paralelamente, células NIH-TAT-GFP já selecionadas foram tratadas com o composto MG132, um potente inibidor de proteossoma (Figura 21a e 21b, respectivamente). Como pode ser observado, nenhuma das duas hipóteses parece explicar o fenômeno de baixa quantidade de células GFP $^{+}$pós-transdução.

A)

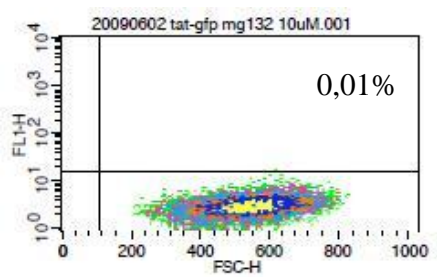

B)

B) Controle negativo

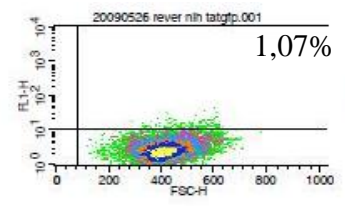

NIH-TAT-GFP

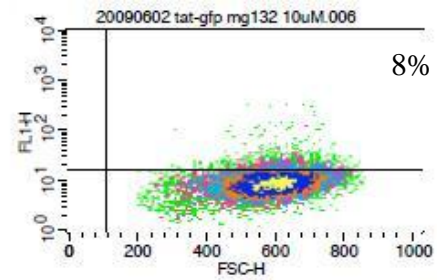

NIH-TAT-GFP

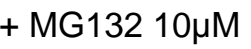

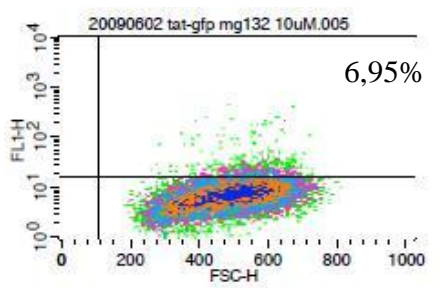

NIH-TAT-GFP

$50 \mu \mathrm{g}$ plasmídeo

$10 \mu \mathrm{g}$ plasmídeo

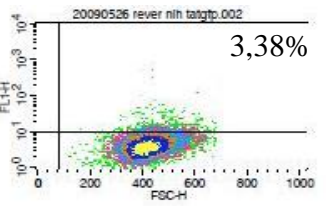

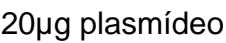

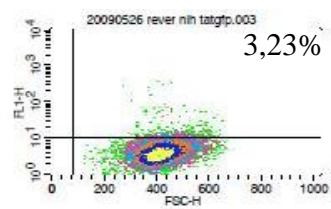

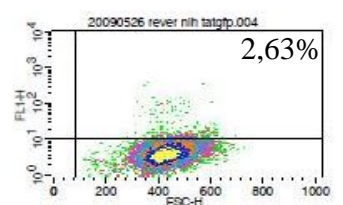

Figura 21: Verificação da hipótese de (A) degradação do proteossoma da proteína TAT-GFP e (B) do efeito da quantidade de DNA na eficiência de produção de retrovírus pCL-TAT-GFP-SN.

Nenhuma das duas manipulações foi capaz de alterar a expressão de TAT-GFP nas células alvo de maneira significativa.

Passou-se então à possibilidade de estar havendo a regulação negativa do gene, em parte da população, e na medida em que o tempo que passa essas células proliferam e ficam sendo a maioria da população. Para verificar isso, fez-se a seleção das colônias verdes de maneira manual ao microscópio invertido e as células foram acompanhadas ao longo do tempo (Figura 22). Dessa forma, conseguiu-se enriquecer a população a aproximadamente $80 \% \mathrm{GFP}^{+}$e a porcentagem de células 
verdes se manteve estável por um longo período. Isso sugere que o fato de haver células resistentes ao geneticin $\mathrm{GFP}^{-}$, seja devido ao silenciamento do promotor do GFP (LTR retroviral), que independe do cassete de expressão do gene de resistência ao antibiótico. Possivelmente, na região da cromatina que houve integração naquelas células, está ocorrendo a expressão do fator de resistência ao antibiótico sem haver expressão concomitante do TAT-GFP.

Procurou-se também verificar se essa população $\mathrm{GFP}^{+}$enriquecida era capaz de produzir e secretar uma quantidade detectável de TAT-GPF ao fluorímetro (Figura 22D). Se sim, o problema do silenciamento gênico poderia ser resolvido rastreando-se os clones que não apresentassem o silenciamento. Contudo, mesmo alterando o parâmetro de potência da lâmpada do fluorímetro para aumentar a sensibilidade do ensaio, não houve detecção de sinal positivo em comparação ao ruído, observado às células controle. 
A)

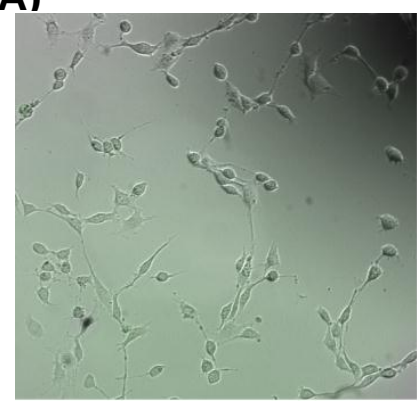

B)

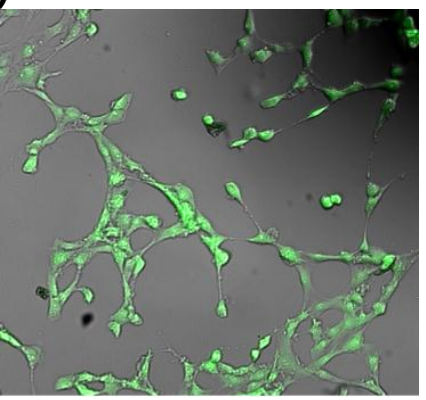

C)

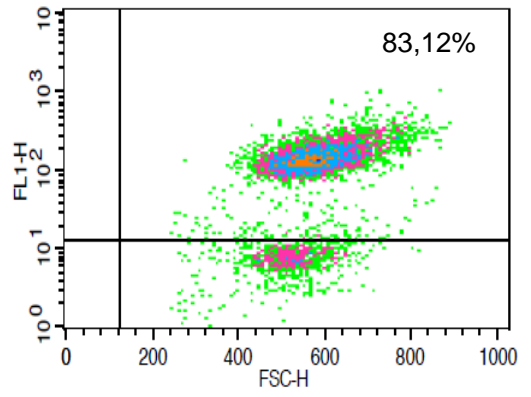

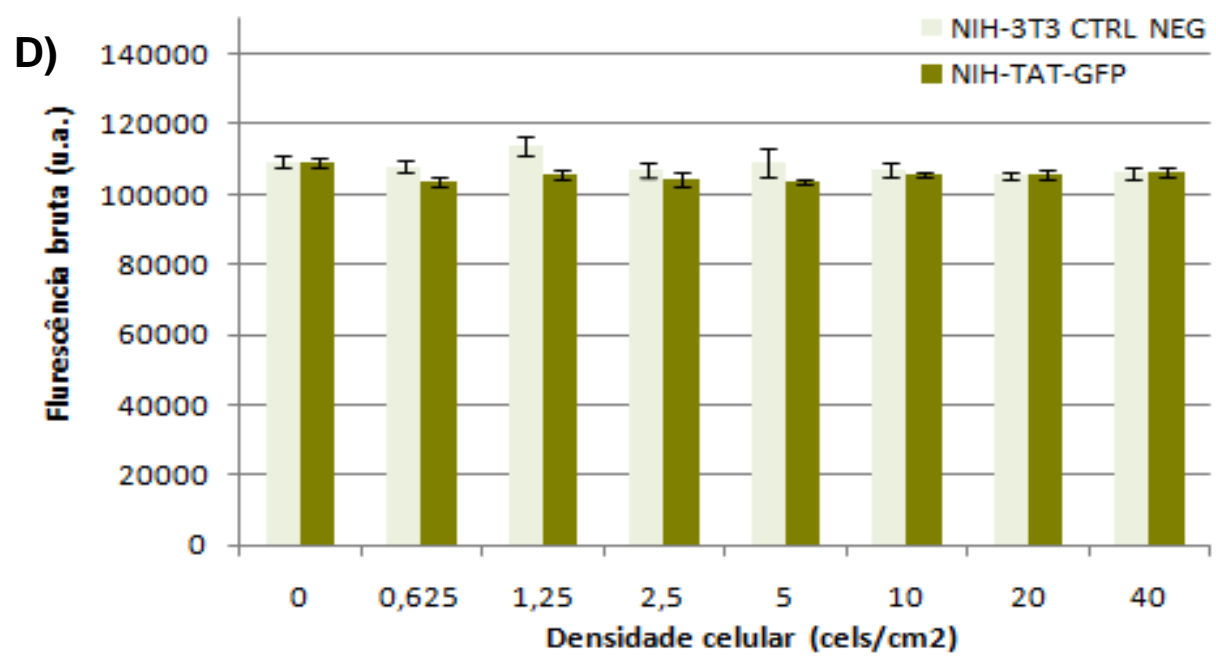

Figura 22: Seleção manual de células verdes para obtenção de colônia 100\% verde. (A) Células não-infectadas (B) células infectadas e selecionadas por geneticin 30 dias e manualmente. (C) Verificação por citometria de fluxo das células selecionadas por geneticin e manualmente. (D) Verificação de fluorescência verde (derivada do TATGFP) no meio condicionado das células retroNIH-TAT-GFP).

Ainda assim, uma vez que o GFP era detectável ao citômetro e ao microscópio dentro das células produtoras, foram realizados ensaios de co-cultura utilizando-se transwell das células retroNIH-TAT-GFP com NIH-3T3 wild type. A expectativa era de que o citômetro de fluxo fosse capaz de detectar sinal nas células produtoras, derivados do TAT-GFP que por elas seria captado (Figura 23). 
A)

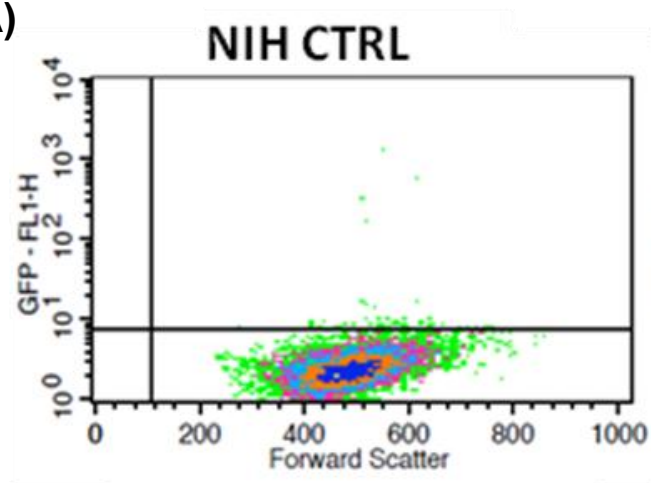

C)

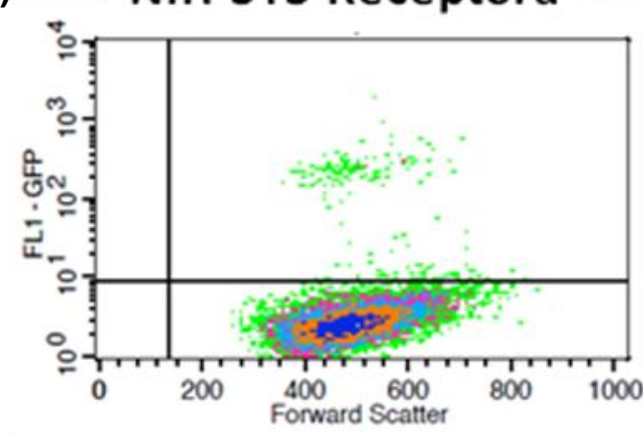

B)

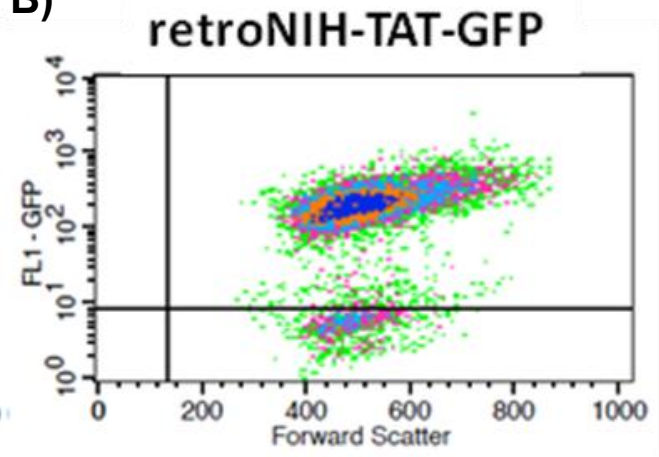

D)

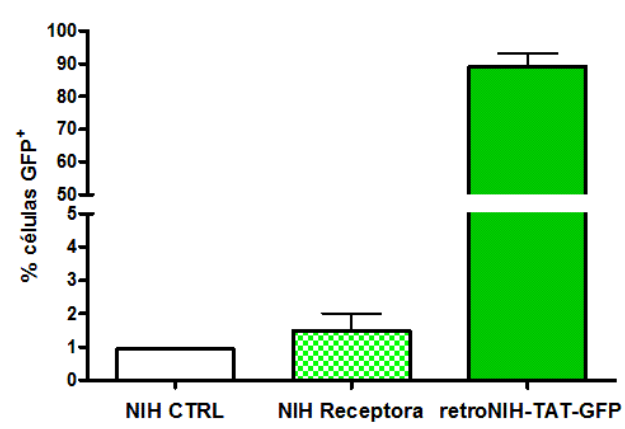

Figura 23: Density plots representativos da intensidade de fluorescência verde (GFP) versus tamanho celular (Forward Scatter, FSC) de células receptoras e produtoras de TAT-GFP em sistema de co-cultura transwell após $24 \mathrm{~h}$ em contato.

(A) NIH-3T3 controle negativo (B) retroNIH-TAT-GFP produtoras e (C) NIH-3T3 receptoras de TAT-GFP. (D) Média e erro padrão de três experimentos independentes.

Nesse experimento foi possível detectar sinal nas células receptoras de TATGFP. Contudo, pode-se observar que a proporção de células que apresentam fluorescência é muito baixa, cerca de 1-2\%, após três dias em co-cultura no sistema transwell de poro de $8 \mu \mathrm{m}$. Esse poro é de tamanho elevado (foi escolhido com o intuito de maximizar a permeabilidade às proteínas), e pode ocorrer migração de células através dele. Uma vez que a intensidade de fluorescência média das células positivas é alta, colocou-se a hipótese de que essas células sejam mais aptas que as demais para transduzir as proteínas ou que, alternativamente, elas sejam contaminantes (produtoras) derivadas da câmara superior. Na tentativa de elucidar 
essa questão, proteína recombinante TAT-GFP (rTAT-GFP, feita em bactérias) que estava a disposição no laboratório foi utilizada para tratar as células e na sequencia foi realizada a verificação por citometria de fluxo do perfil de transdução da TATGFP em função da quantidade de proteína (Figura 24).
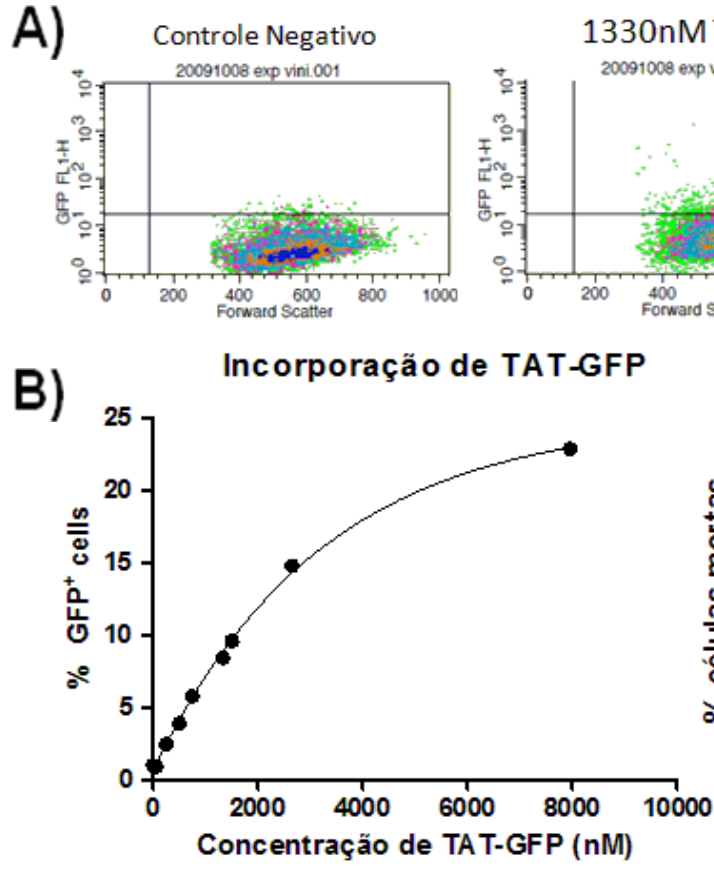
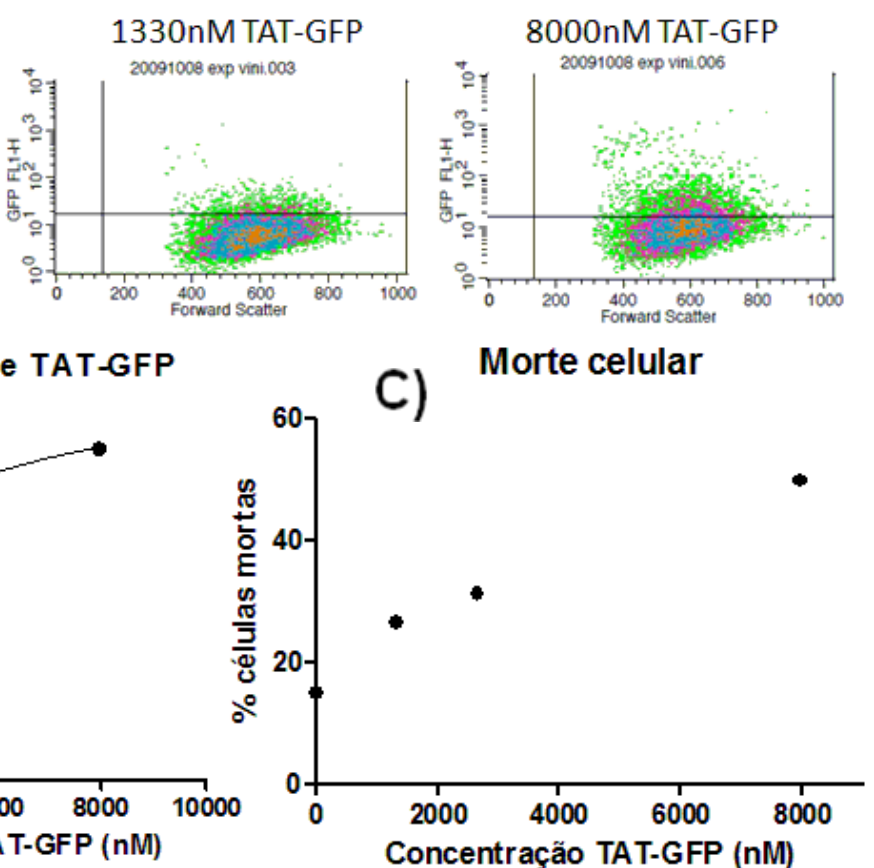

Figura 24: Perfil na citometria de fluxo após tratamento com TAT-GFP recombinante.

(A) Density plots representativos da intensidade de fluorescência verde (GFP) versus tamanho celular (Forward Scatter, FSC) de células NIH-3T3 que foram tratadas com diferentes doses de rTAT-GFP recombinante. O efeito do tratamento na (B) incorporação de rTAT-GFP e na $(\mathbf{C})$ morte celular é dose dependente $(\mathrm{N}=1)$.

É possível notar que o perfil de marcação nos density plots das células tratadas com proteína recombinante é diferente do experimento com transwell. $\mathrm{Na}$ medida em que se aumenta a concentração das proteínas, as células ficam gradativamentes com intensidade de fluorescência maiores quanto maior a porcentagem da população que fica verde. Isso indica que a marcação do experimento anterior, onde há poucas células com alta intensidade de fluorescência, é provavelmente devida às células que conseguiram migrar através dos poros do 
transwell. Por outro lado, nesse experimento com proteínas recombinantes ficou bastante evidente a morte celular ao microscópio (dados não mostrados), que pode ser devido à uma série de fatores como contaminantes das bactérias ou a própria citotoxicidade do GFP, que não foram investigadas. A morte celular foi confirmada, por sua vez, na citometria de fluxo (aumento dose dependente de células no gate de tamanho e granulosidade muito reduzidos, figura 24C).

Com a intenção de evitar que houvesse contaminantes no meio de cultura, na sequência foi realizado um experimento utilizando meio condicionado (após $24 \mathrm{~h}$ em contato com as retroNIH-TAT-GFP produtoras) que foi centrifugado para remover as possíveis células contaminantes e passado para a placa de células receptoras. As células foram avaliadas após $24 \mathrm{~h}$ em contato com o meio condicionado. Além disso, foi investigada aqui a possível influência do FBS no processo (Figura 25). Foram realizados também experimentos com períodos mais longos de condicionamento (até sete dias), obtendo-se resultados semelhantes (dados não mostrados). 
$1 \% \mathrm{FBS}$
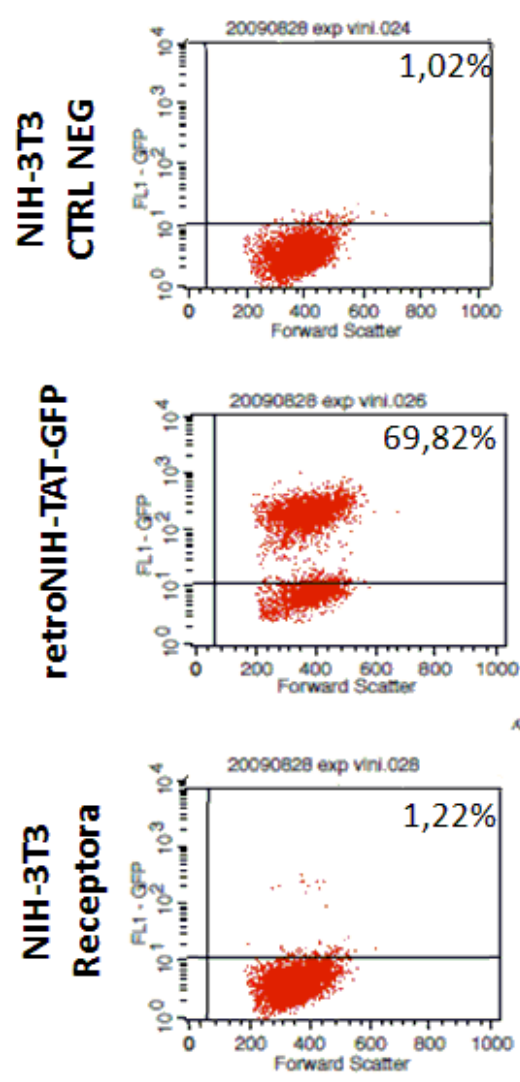

$10 \%$ FBS
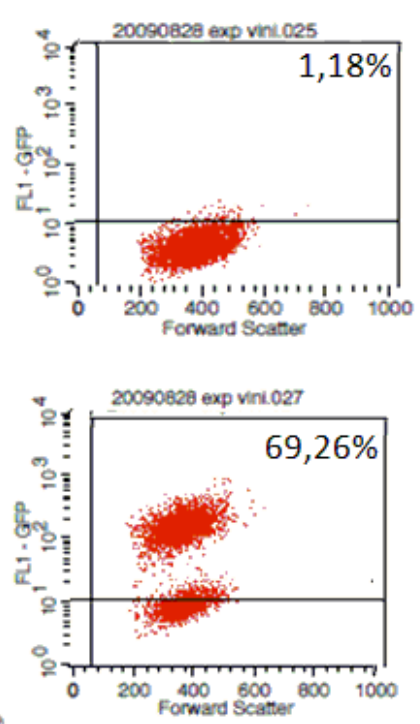

a.

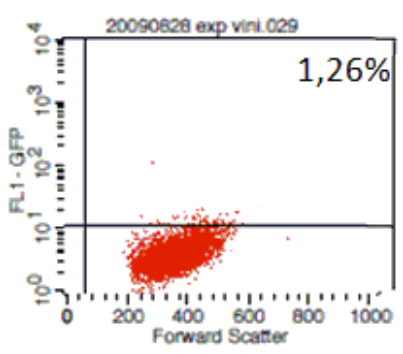

Figura 25: Tratamento de células NIH-3T3 receptoras com meio condicionado. Density plots representativos da intensidade de fluorescência verde (GFP) versus tamanho celular (Forward Scatter, FSC) obtidos após tratamento de células NIH-3T3 receptoras com meio condicionado por $24 \mathrm{~h}$ em células NIHretro-TAT-GFP. O meio foi centrifugado para garantir a remoção das células produtoras. $(\mathrm{N}=1)$

Juntos, esses resultados indicam que o efeito obtido por transwell de $8 \mu \mathrm{m}$ com o sistema TAT-GFP não se deve à transdução de proteínas nas células receptoras. Se a cadeia de eventos "produção-secreção-transdução" da proteína TATGFP estiver ocorrendo por inteira, está em uma concentração tão baixa no meio de cultura que não é detectável no fluorímetro e incapaz de acumular de maneira detectável por citometria de fluxo. Com esses dados, é possível também levantar a hipótese de que as células $\mathrm{GFP}^{+}$que foram selecionadas manualmente apresentam a alta intensidade de fluorescência devido a algum problema na secreção, ficando a 
TAT-GFP acumulada dentro das células. Ou seja, é possível que as células produtoras que apresentam altos índices de fluorescência estejam com esse fenótipo por não conseguirem secretar bem o TAT-GFP.

\subsection{Determinação da escala de detecção de GFP fluorímetro.}

Para permitir que os dados de detecção de GFP no meio de cultura pudessem ser apresentados em unidade de concentração, ao invés de unidades arbitrárias de fluorescência, foi realizada uma curva-padrão de fluorescência "universal" utilizando-se proteína recombinante TAT-GFP (rTAT-GFP) como referencial (Figura 26). Para efetuar os cálculos, a concentração da rTAT-GFP foi determinada pelo método de Bradford e seu grau de pureza por SDS-PAGE com Coomassie blue. A equação regressão linear resultante da associação entre a diluição seriada de concentrações conhecidas de rTAT-GFP e seus os respectivos deltas de sinais de fluorescência em relação ao ruído foi posteriormente utilizada para inferir a concentração molar de GFP. 
A)

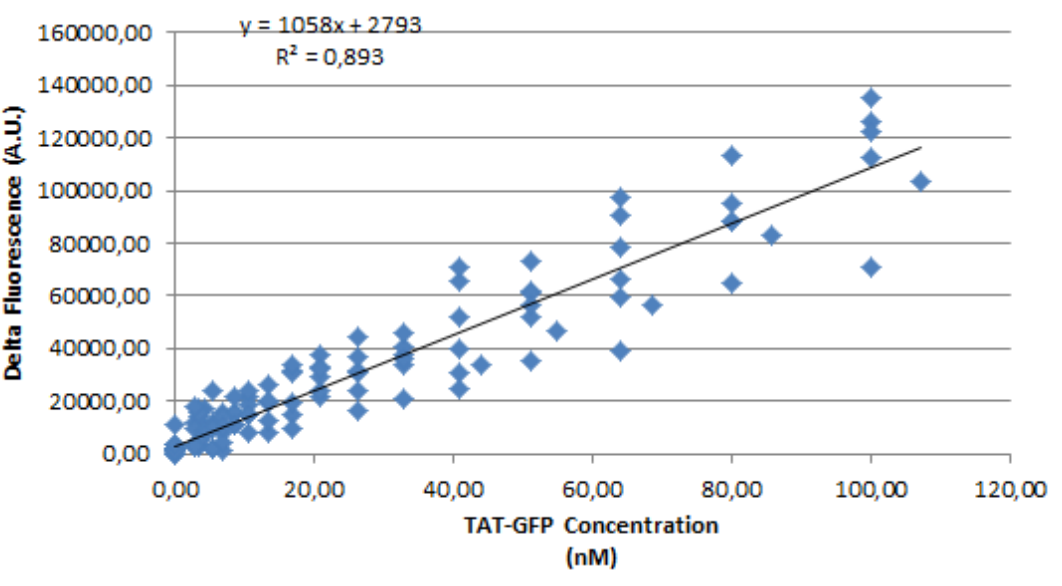

B)

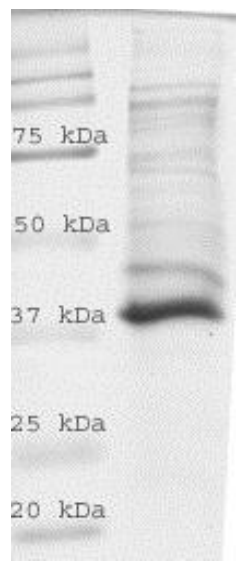

Figura 26: Curva padrão de rTAT-GFP

(A) rTAT-GFP com uma concentração conhecida foi diluído em meio DMEM (sem fenol red) suplementado com 1\% de FBS e foi realizada uma diluição seriada. A fluorescência foi determinada em sete curvas independentes utilizando-se o fluorímetro. Uma vez que o ruído basal varia entre os experimentos, a curva-padrão foi construída com base na diferença de fluorescência e o sinal de ruído. (B) Determinação pureza da rTAT-GFP por SDS-PAGE (46,5\% de proteínas presentes eram rTAT-GFP e esta informação foi levada em conta na determinação da concentração efetiva de rTAT-GFP).

Como pode ser observado, uma concentração nanomolar variando de 12,5 a $120 \mathrm{nM}$ pode ser distinguida com este método, de uma forma linear e com um valor relativamente elevado do coeficiente de determinação $\left(\mathrm{R}^{2}\right)$. Valores maiores também foram ensaiados (até 1200nM rTAT-GFP), com um coeficiente angular equivalente (dados não mostrados). A equação de regressão linear apresentada acima foi utilizada para converter dados de fluorescência em concentração estimada em experimentos. Apesar de simples, esta é uma anotação útil, pois facilita o entendimento do intervalo de concentração que está sendo abordado.

\subsection{Sistema pSecTag2}

Na sequência os esforços foram concentrados para serem obtidas linhagens TATк-fator, ou seja, contendo a sequência mutada do peptídeo TAT, para impedir a 
ação de furin endoproteases e por consequência aumentar seu nível de expressão e secreção nas células ${ }^{76}$. Ainda que tenha sido desenvolvido no laboratório os sistemas retroviral TAT-fator e TATк-fator em plasmídeos retrovirais pCL-X-SN, eles não foram mais utilizados, na tentativa de evitar o mesmo silenciamento gênico observado anteriormente.

\subsubsection{Avaliação da melhor linhagem produtora}

Uma vez que células diferentes podem apresentar diferentes performances de expressão e secreção de proteínas transgênicas ${ }^{97}$, verificou-se a expressão de pSecTAg-TATк-GFP em seis tipos de linhagens celulares (CHO, NIH-3T3, HT1080, HEK-293A, HEK-293t e COS-7) baseado na produção de proteínas fluorescentes quatro dias após a transfecção usando o citômetro de fluxo.

Cada tipo celular foi testado para dois tipos de choque após transfecção de fosfato de cálcio (15\% glicerol ou 10\% DMSO, conforme instrução do fabricante) e três diferentes intervalos de tempos $(3 \mathrm{~h}, 6 \mathrm{~h}$ e $\mathrm{O} / \mathrm{N})$, para a transfecção por lipofectamina (Figura 27). 


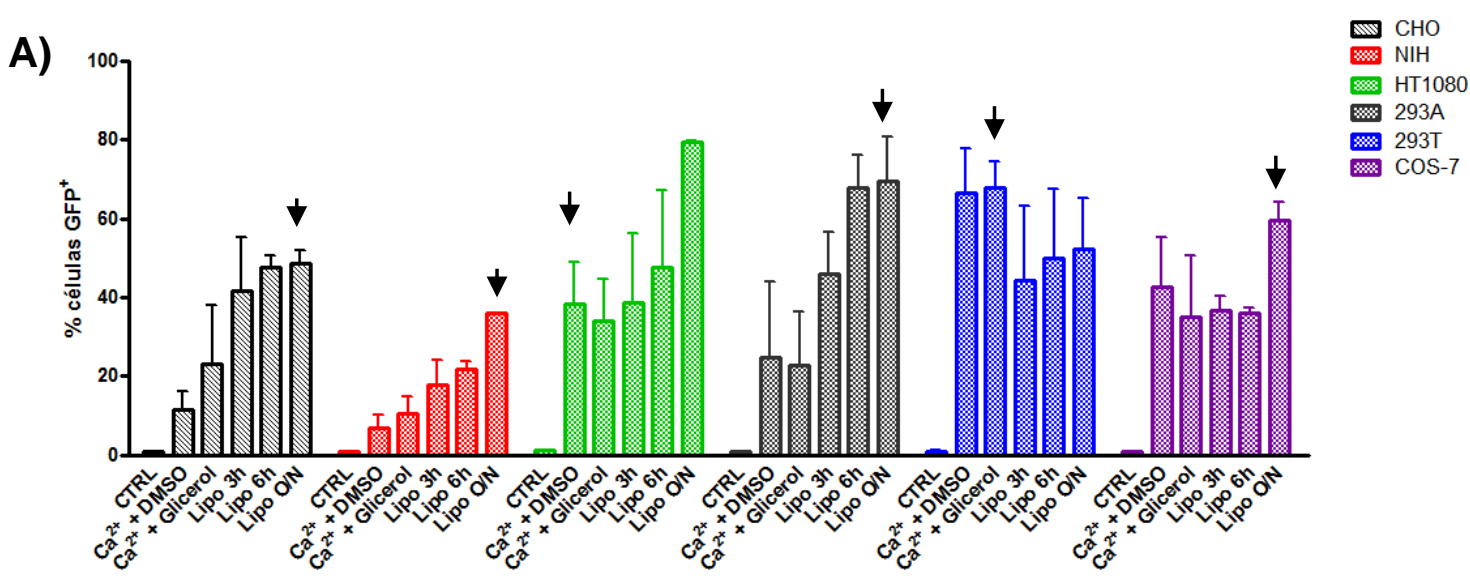

B)

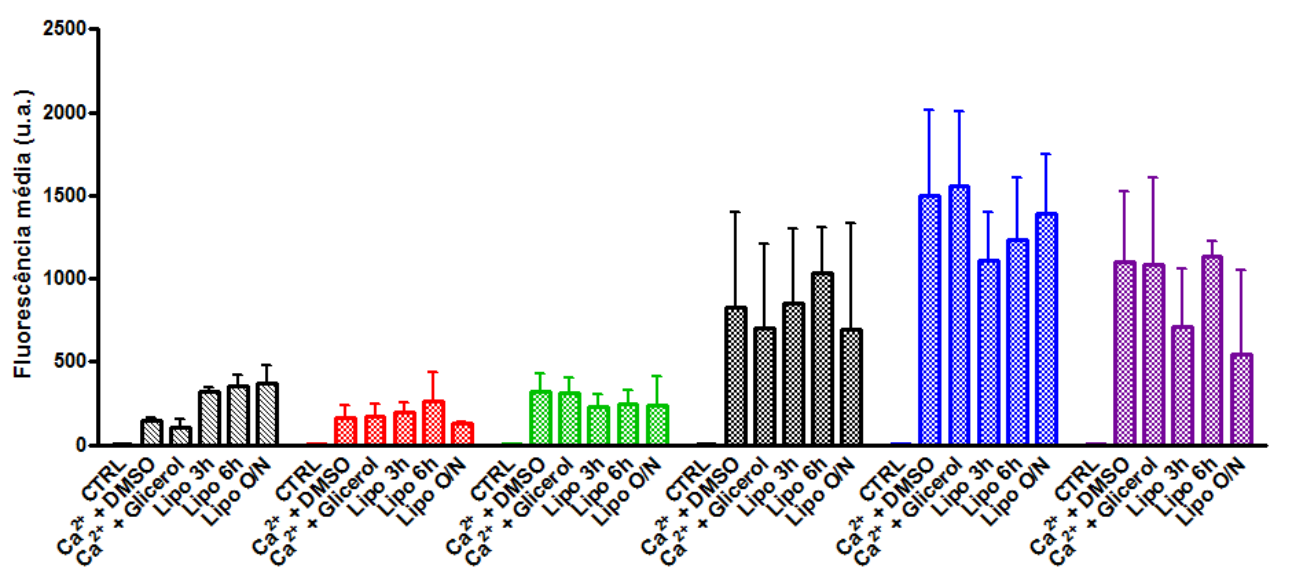

Figura 27: Rastreamento da eficiência de transfecção do plasmídeo pSecTag2TATк-GFP em seis diferentes linhagens de células após $48 \mathrm{~h}$.

Média \pm erro padrão da (A) porcentagem de células $\mathrm{GFP}^{+}$. As condições de maior valor (setas pretas) foram utilizadas posteriormente para a transfecção das linhagens contendo a sequência dos fatores de transcrição, exceto HT1080, que por transfecção por lipofectamina apresentou morte celular muito acentuada após alguns dias da transfecção. (B) Intensidade de fluorescência média em função das condições de transfecção, para cada tipo celular.

As condições de maior de porcentagem de células verdes foram as que foram posteriormente utilizadas para a transfecção dos plasmídeos dos fatores de transcrição (OSKM), exceto HT1080, que na transfecção por lipofectamina curiosamente apresentou alta morte celular após alguns dias. É importante observar também que independente da porcentagem de $\mathrm{GFP}^{+}$, as células apresentam uma 
variação muito grande quanto à intensidade de fluorescência média, por célula. Isso indica que elas expressam GFP em diferentes magnitudes. As que apresentam maiores valores são as 293t, seguido de 293A e COS7. As demais apresentam valores bastante diminutos, inclusive a NIH-3T3.

$\mathrm{Na}$ sequência, passou-se a seleção por antibiótico Zeocin e a primeira linhagem a ser selecionada foi a 293t-pSec-TATא-fatores. Dentre as outras linhagens, houveram problemas na seleção da COS7-pSec-TATк-GFP e da HT1080-

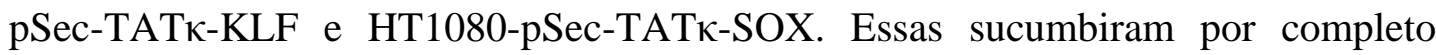
durante processo de seleção.

Logo que possível foi realizada a tentativa de detecção de TATк-GFP no sobrenadante usando o fluorímetro, já com os parâmetros modificados em relação ao primeiro experimento desse tipo (Figura 28). 

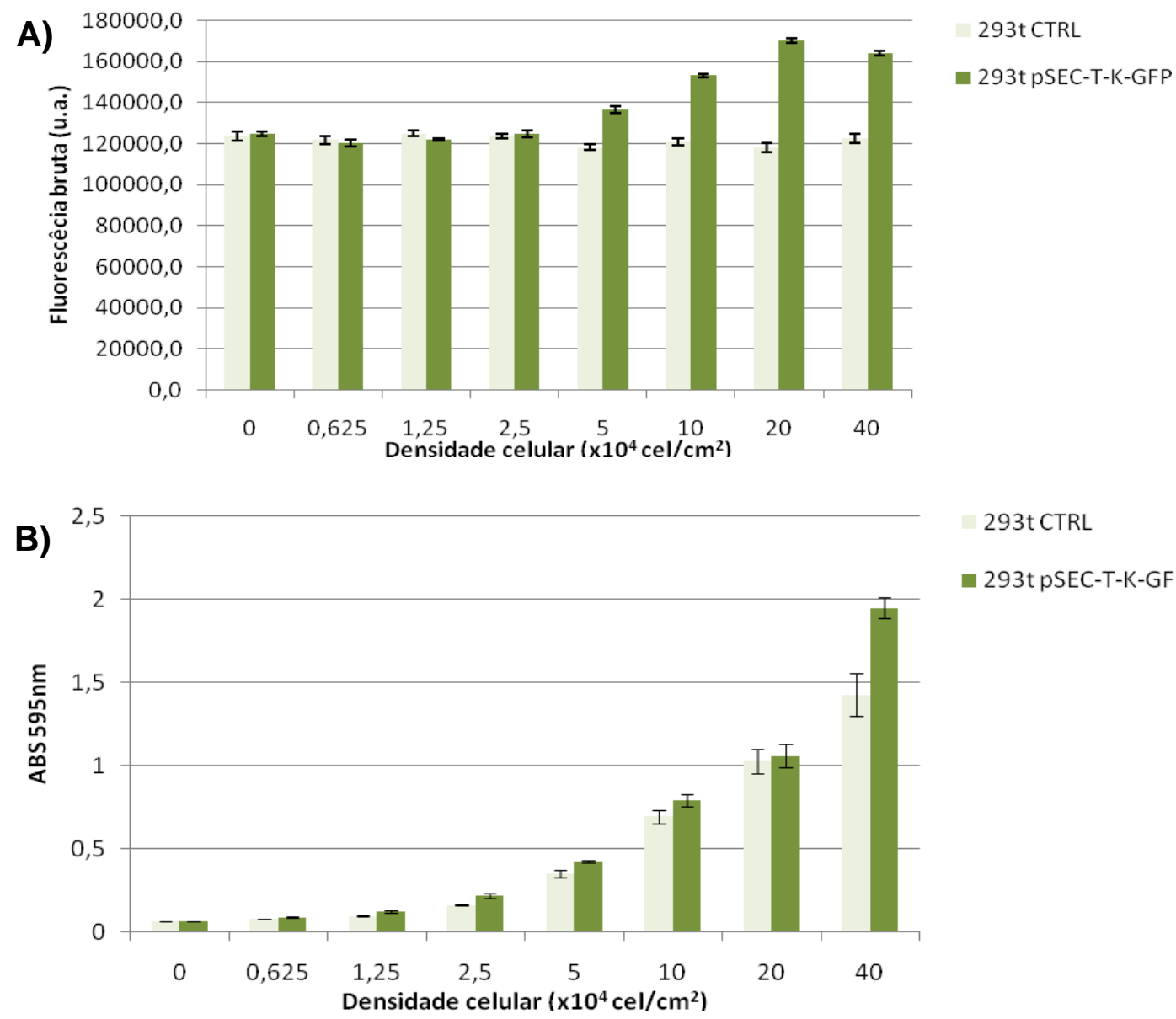

293 t CTRL

Figura 28: Detecção de TATк-GFP no sobrenadante no fluorímetro após 24h.

(A) Foi realizada uma curva de densidade celular em placas de 96 poços com o intuito de se detectar a proteína TATк-GFP no sobrenadante. (B) Em paralelo foi verificado que esse efeito não é devido a diferenças na viabilidade em função da densidade celular (ensaio de MTT).

Pela primeira vez, um sinal positivo significativo no meio de cultura de células produtoras foi obtido e demonstrou-se que não é devido diferenças de viabilidade celular entre os grupos (Tא-GFP e controle). Motivados por esse resultado e pelo fato da $293 \mathrm{t}$ oferecer o maior valor de intensidade de fluorescência na citometria de fluxo, procurou-se estabelecer a influência do tempo na produção/secreção da proteína TATא-GFP (Figura 29). 


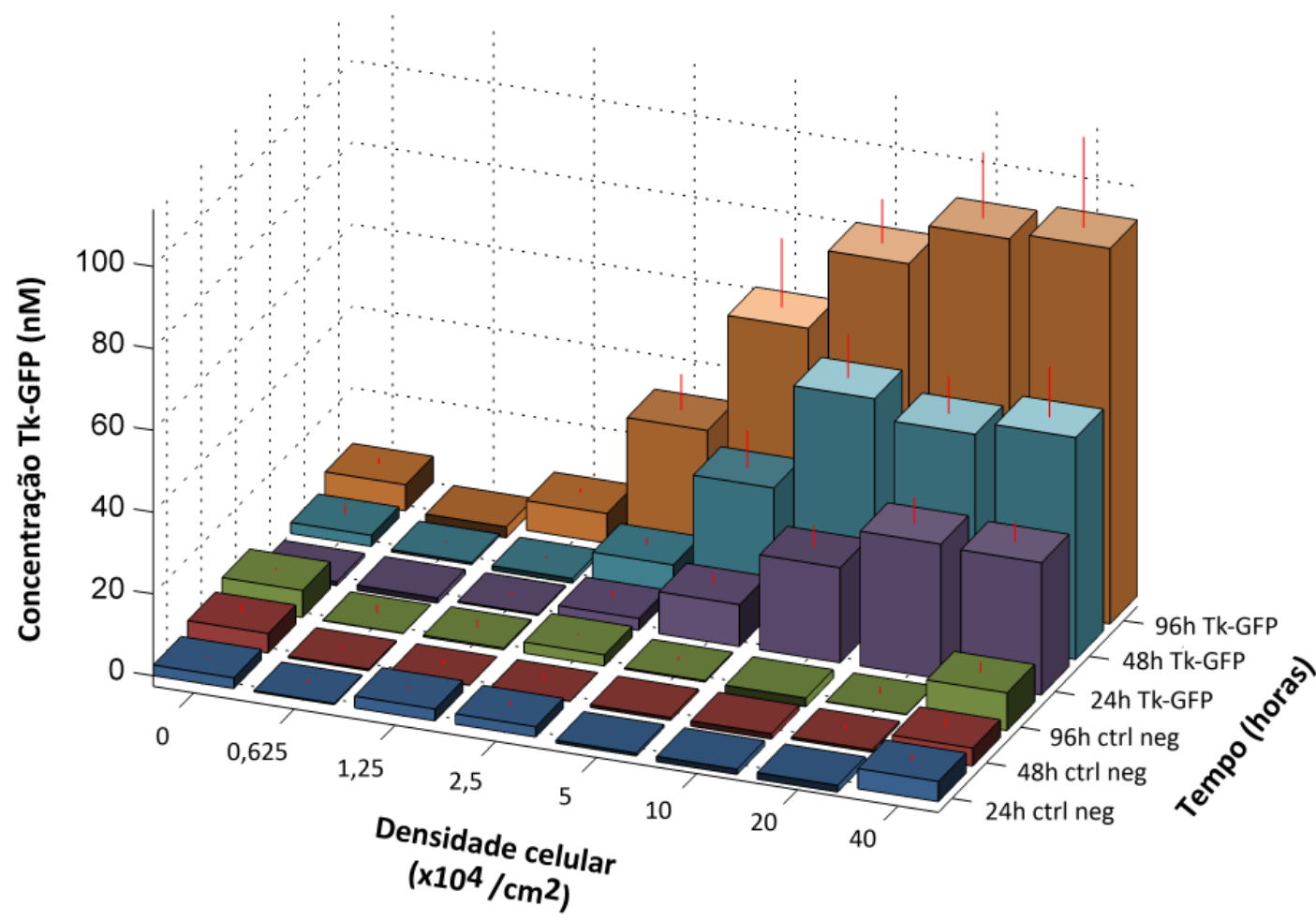

Figura 29: Verificação da influência do tempo (24, 48 e 96h) no perfil de secreção

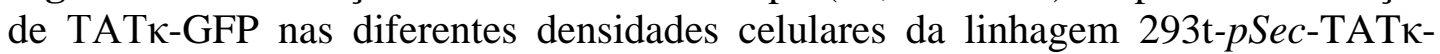
GFP.

Média \pm EPM, $\mathrm{N}=3-4$.

Esses resultados mostram que a produção de TATא-GFP pela linhagem 293tpSec-TATк-GFP é detectável em $24 \mathrm{~h}$ a partir de $10 \times 10^{4}$ cels $/ \mathrm{cm}^{2}$ e atinge um platô quando a quantidade de células e o tempo de condicionamento são elevados (de $10 \times 10^{4}$ a $40 \times 10^{4}$ células $/ \mathrm{cm}^{2}$ após $96 \mathrm{~h}$ ). Pode-se observar que a densidade celular de $10 \times 10^{4}$ cells $/ \mathrm{cm}^{2}$ por $24 \mathrm{~h}$ foi a condição na qual houve a possibilidade de detecção de produção TATк-GFP no menor intervalo de tempo. Além disso, foi possível se detectar um sinal significativo com tão poucas células quanto $2,5 \times 10^{4}$ células $/ \mathrm{cm}^{2}$ ao se aguardar 96h. Verificar o tempo mínimo para produção é importante, pois pode evitar a possibilidade de degradação das proteínas. 
$\mathrm{Na}$ sequência, foram realizados experimentos de $24 \mathrm{~h}$ com as diversas linhagens produtoras de TATк-GFP obtidas, com a finalidade de compará-las e se identificar qual seria a produtora de maior eficiência (Figura 30).

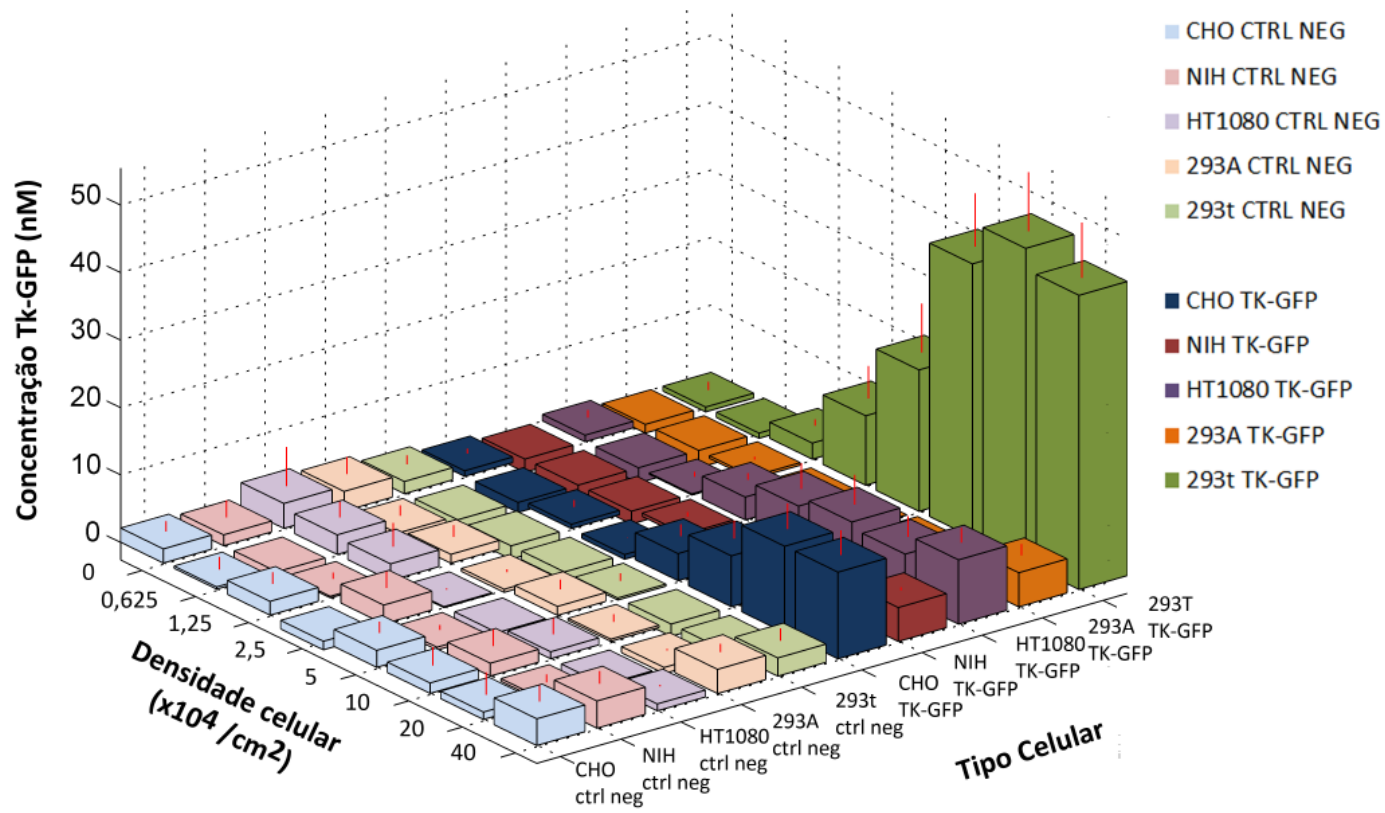

Figura 30: Rastreamento do maior potencial de secreção de TATא-GFP entre os seis tipos celulares testados.

O ensaio foi realizado condicionando-se meio de iPS por $24 \mathrm{~h}$ com as células na densidade de $10 \times 10^{4}$ cels $/ \mathrm{cm}^{2}$ A linhagem COS-7pSeC-TATк-GFP não estão incluídas na imagem, pois foram perdidas no processo de seleção por antibiótico. (Média \pm EPM N=2-4).

A linhagem 293t-pSec-TATк-GFP teve o melhor desempenho, seguido da

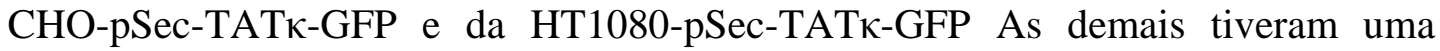
produção não significativa, comparável ao ruído observado nos controles negativos. Isso indica que a porcentagem e a intensidade de fluorescência obtida por cada linhagem logo após a transfecção dos plasmídeos (Figura 27) não confere necessariamente fator preditivo para o potencial de secreção das linhagens após a seleção de longo prazo com os antibióticos. 
Utilizando as melhores condições de transfecção estabelecidas para cada tipo de célula com o TATк-GFP, o processo para obter células produtoras foi repetido

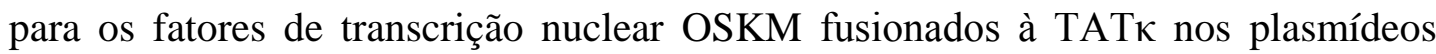
pSECTag2, seguido da seleção utilizando o antibiótico Zeocin. A partir de ensaios de ELISA para a detecção dos fatores de transcrição no meio sobrenadante (previamente padronizados, ver Apêndice IV) foi possível se estabelecer a quantidade dos fatores de transcrição que estava sendo produzido por cada tipo celular. Para isso foi utilizada a densidade celular e o tempo otimizado anteriormente $\left(10 \times 10^{4}\right.$ células $/ \mathrm{cm}^{2}$ por 24h, Tabela 3).

Tabela 3: Determinação por ensaio de ELISA da quantidade de proteína TATк-fator que é secretada dependendo do tipo celular.

Destacado em vermelho estão as linhagens maior performance de secreção. O ensaio foi realizado condicionando-se meio de iPS por $24 \mathrm{~h}$ com as células na densidade de $10 \times 10^{4}$ cels $/ \mathrm{cm}^{2}$. Legenda: * = Sinal não detectável, N/A = condição não disponível.

\begin{tabular}{|c|c|c|c|c|}
\hline & $\begin{array}{c}\text { TATא-OCT } \\
(n M)\end{array}$ & $\begin{array}{c}\text { TATK-SOX } \\
(n M)\end{array}$ & $\begin{array}{c}\boldsymbol{T A T K - K L \boldsymbol { F }} \\
(n M)\end{array}$ & $\begin{array}{c}\boldsymbol{T A T \boldsymbol { T }}-\boldsymbol{M Y C} \\
(n M)\end{array}$ \\
\hline HT-1080 & $*$ & $*$ & $\mathrm{~N} / \mathrm{A}$ & $*$ \\
\hline COS-7 & $*$ & $*$ & $36,94 \pm 1,46$ & $*$ \\
\hline NIH-3T3 & $1,69 \pm 0,14$ & $1,25 \pm 0,05$ & $14,98 \pm 0,11$ & $*$ \\
\hline 293A & $5,54 \pm 0,36$ & $5,6 \pm 0,02$ & $114 \pm 0,3$ & $*$ \\
\hline $293 t$ & $1,34 \pm 0,03$ & $16,58 \pm 0,28$ & $149,1 \pm 1,6$ & $1,54 \pm 0,04$ \\
\hline CHO & $0,21 \pm 0,01$ & $15,74 \pm 0,04$ & $42,23 \pm 0,83$ & $*$ \\
\hline
\end{tabular}

É possível notar que as linhagens produtoras de TATк-KLF, independente do tipo celular, apresentam excelente desempenho na produção de fatores, atingindo uma concentração de proteínas no meio extracelular semelhante $(8 \mu \mathrm{g} / \mathrm{mL}$, equivalente aproximadamente a 100-150 nM, dependendo da proteína) ao que foi utilizado no trabalho publicado recentemente que utilizou proteínas recombinantes de bactérias ${ }^{110}$. Contudo, as demais (principalmente TATк-MYC) ainda apresentam uma taxa de produção relativamente baixa e precisariam ser melhoradas. Com as 
linhagens disponíveis foi possível fazer uma combinação de número de células de cada uma delas de tal forma que a concentração final estimada de todas as proteínas fosse a mesma $(52 \mathrm{ng} / \mathrm{mL})$ em $24 \mathrm{~h}$. Essa combinação foi utilizada em um dos experimentos posteriores. Uma vez que já foi relatado que é possível gerar iPS apenas com 3 fatores (OCT, SOX e KLF) ${ }^{111}$, outra possibilidade a ser investigada poderia ser usar apenas três produtoras. Isso pode ser interessante, pois conferiria uma concentração final três vezes maior de cada um dos fatores (aproximadamente $156 \mathrm{ng} / \mathrm{mL}$ em 24h). Nesse primeiro momento procurou-se não mudar a igual proporção entre os quatro fatores, haja vista que foi demonstrado que, em sistema viral, essa seria a combinação de maior eficiência - exceto para quando há três vezes mais OCT disponível ${ }^{79}$, que, como sendo produzido em baixa concentração, não é uma combinação vantajosa de ser realizada.

Com relação às produtoras que apresentaram índices nulos de secreção no ELISA, a fim de verificar se realmente há pelo menos os RNAm sendo produzidos foi realizado um ensaio de RT-PCR usando dois pares de primers, um onde toda a proteína é amplificada e o outro onde apenas um amplicon 200 bp (Figura 31). Como pode ser observado, ambas as linhagens estão produzindo o RNAm dos fatores de transcrição nuclear correspondentes, inclusive as produtoras de cMYC, que não foram detectáveis por ELISA. Portanto, a disponibilidade de proteína no meio de cultura parece ser devido a características específicas do fenótipo de expressão ou secreção dessas células. 
A)

$\begin{array}{lll}\text { 293T-Tk-OCT 293T-Tk-SOX 293T-Tk-MYC } & \text { 293T-Tk-KLF }\end{array}$
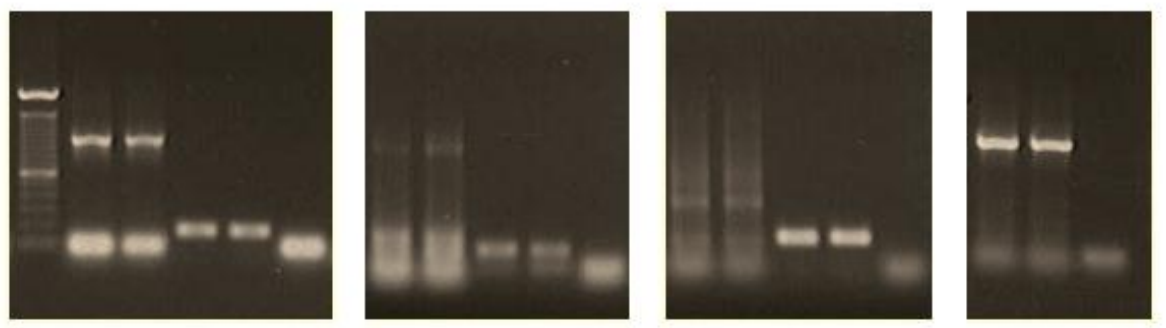

$\begin{array}{llll}1 & 2 & 3 & 4\end{array}$

$\begin{array}{llll}1 & 2 & 3 & 4\end{array}$

$\begin{array}{llll}1 & 2 & 3 & 4\end{array}$

12

NIH-3T3 Tk-OCT

NIH-3T3 Tk-SOX

NIH-3T3 TK-KLF

NIH-3T3 Tk-MYC

B)
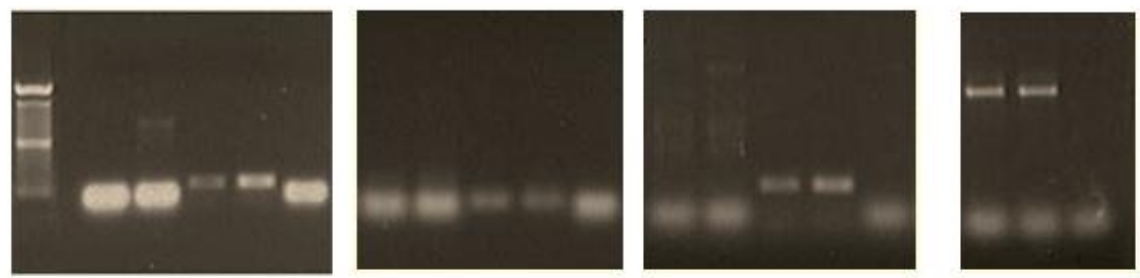

$\begin{array}{lll}1 & 2 & 3\end{array}$

1

12

Figura 31: Verificação da expressão gênica de TATк-fatores por RT-PCR.

As linhagens derivadas de (A) 293t e (B) NIH-3T3 foram selecionadas com zeocin e ensaiadas quanto a expressão de OSKM. Exceto para NIH-TATK-SOX, todas as linhagens celulares apresentaram expressão para ambos os ensaios de ambos os primers.

Números 1, 2, 3 e 4 indicam, respectivamente, a amostra e controle positivo ambos ensaiados com primers para produtos de genes inteiro, na sequencia, a amostra e o positivo são ensaiados com os primers de amplicon de $200 \mathrm{pb}$ e, finalmente, tem-se o controle negativo de reação (sem amostras). Note que, apesar de não ter amplificado com os primers para o gene inteiro, o NIH-pSec-TATא-SOX-pode ser amplificado quando pelo outro par de primer (200 pb).

\subsubsection{Investigação das limitações do sistema}

$\mathrm{Na}$ sequência, foi testada a hipótese de que diferentes graduações de

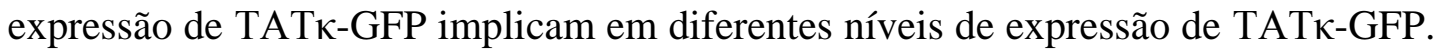
Se isso se confirmar, é possível se extrapolar esses resultados para entender um porque da grande dificuldade da utilização do sistema retroNIH-TAT-GFP. Para isso, foi realizada a separação da linhagem 293t-pSec-TATк-GFP em três populações distintas usando um citômetro FACsAria II (Figura 32). 
A)

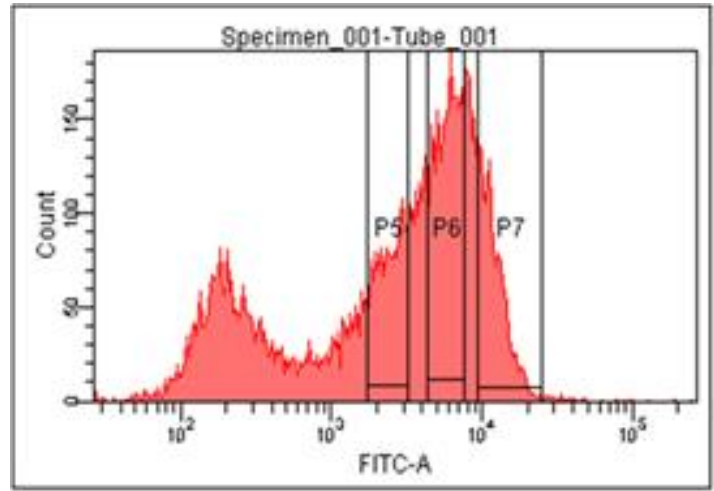

B)

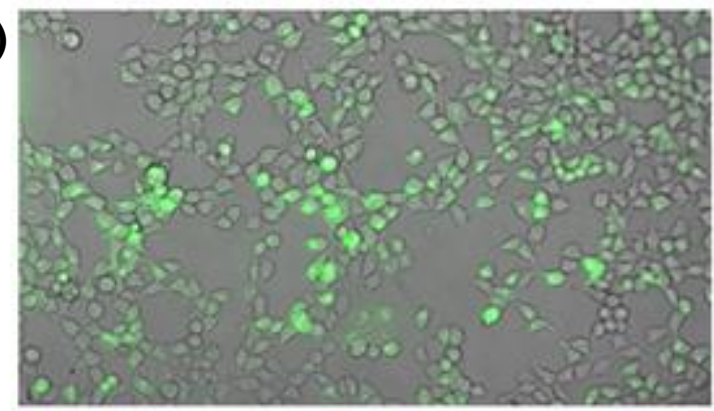

C)

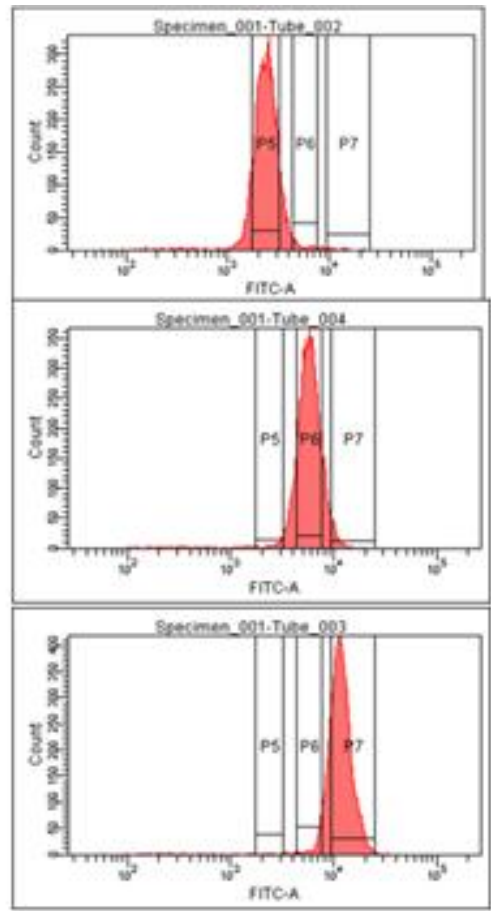

Figura 32: Cell sorting da linhagem 293t-pSec-TATк-GFP.

(A) Perfil em histograma e (B) visualização por microscopia de fluorescência da população antes da separação (Aumento de 100x). As populações P5, P6 e P7 foram separadas de acordo com os gates apresentados. (C) Perfil das populações logo após a separação. Ao final do processo, obteve-se, respectivamente, $67 \%, 64 \%$ e $86 \%$ de células que voltaram a cair nos gates criados para a separação, indicando o sucesso da separação.

Após aproximadamente uma semana em cultivo para haver restabelecimento de um número de células da cultura, foram realizados experimento de verificação da expressão nas células (por citometria de fluxo) e secreção de TATк-GFP no sobrenadante por fluorímetro (Figura 33). 
A)

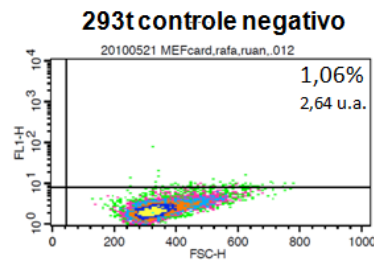

psec293t-Tk-GFP "poucoexpresso"
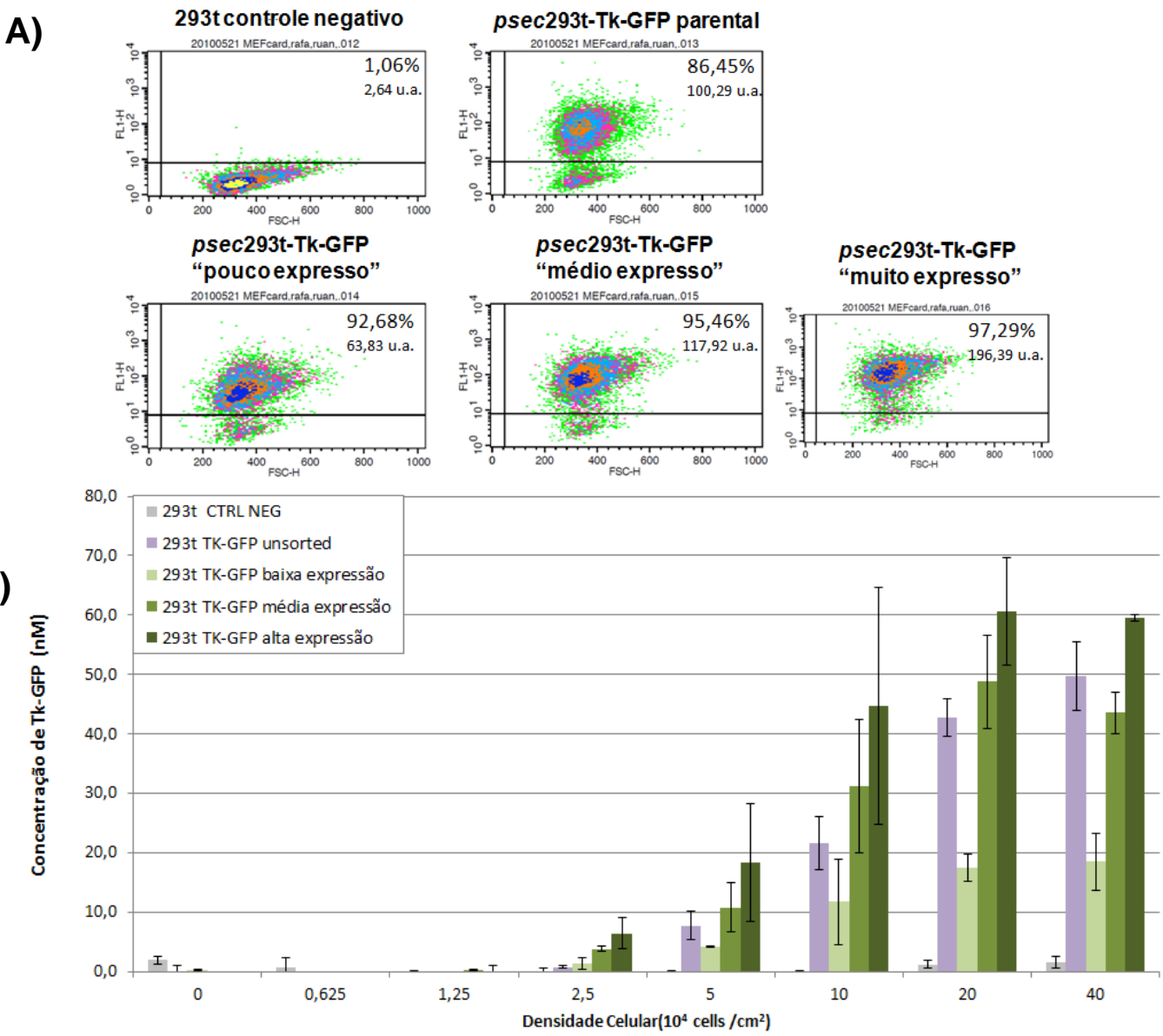

C)

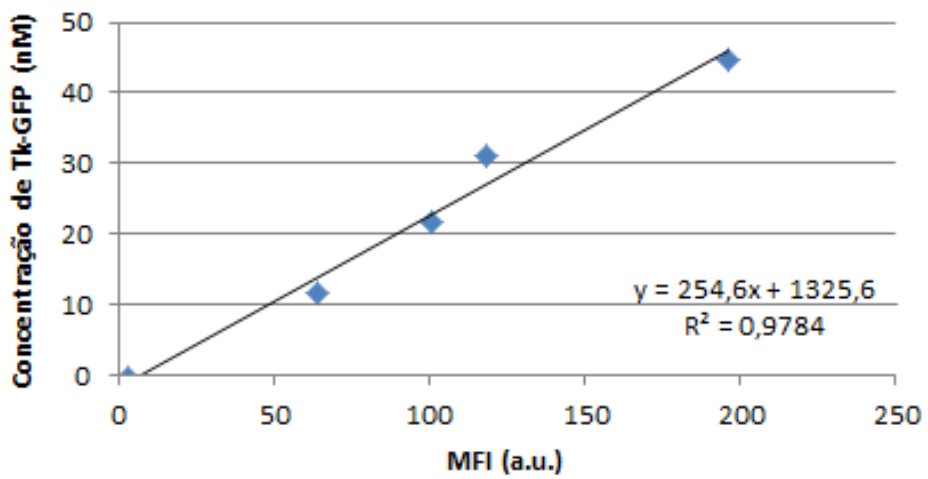

Figura 33: Separação da linhagem 293t-pSec-TATк-GFP em 3 populações.

(A) Densitiy plots representativos das populações após 1 semana da realização do sorting. As células não perdem o perfil obtido pós-sorting e apresentam variações significativas da intensidade de fluorescência média (porcentagem e intensidade de fluorescência média da população no canto superior direito). (B) Perfil de secreção

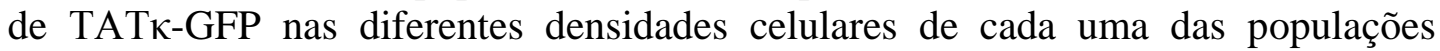
separadas após 24h. (C) Gráfico da correlação da intensidade de fluorescência média de cada população com o sinal obtido no ensaio de verificação de TATк-GFP no meio condicionado por $24 \mathrm{~h}$. $(\mathrm{r}$ de Pearson $=0,9883, \mathrm{P}<0,01)$ 
Com esse experimento foi possível observar que na medida em que a população expressa mais TATא-GFP, maior é a quantidade de proteína detectável no meio condicionado e há uma forte correlação entre essas variáveis.

Perde a validade, portanto, a hipótese levantada anteriormente de que as proteínas TAT-GFP estavam acumuladas nas células que células retroNIH-TATGFP que foram selecionadas manualmente (as de maior expressão gênica). As células que estão mais verdes não estão assim porque não conseguem secretar o transgene. Quando a linhagem NIH-3T3 foi transfectada com o sistema pSec-TкGFP ela se manteve com baixo índices de produção de proteína. Portanto, essa parece ser uma característica dessa linhagem, sendo a NIH-3T3 (assim como a COS-7) um exemplar de baixa eficiência de secreção. No nosso caso, como é desejado obter uma população que expresse e secrete o máximo possível de cada fator de transcrição, foi importante investigar todas.

O desempenho células 293t em secretar TATא-GFP chama a atenção e sugere a hipótese de que se esse tipo de célula for transfectado com o plasmídeo pSecTagTAT-GFP (em vez de NIH-3T3, como feito anteriormente), níveis detectáveis de proteína possivelmente possam ser observados em meio de cultura por fluorímetro (Figura 34). Conforme pode ser observado, mesmo a partir de uma população de células 293 t $62 \%$ TAT-GFP ${ }^{+}$separada por sorting em citometria de fluxo, não é possível ser observado níveis detectáveis (acima de 12nM) de TAT-GFP no fluorímetro. A título de comparação, o mesmo processo foi feito com a população СНО-ТАТк-GFP, separada por citometria de fluxo, e uma quantidade consideravelmente alta é detectada é obtida, nas mesmas condições. 

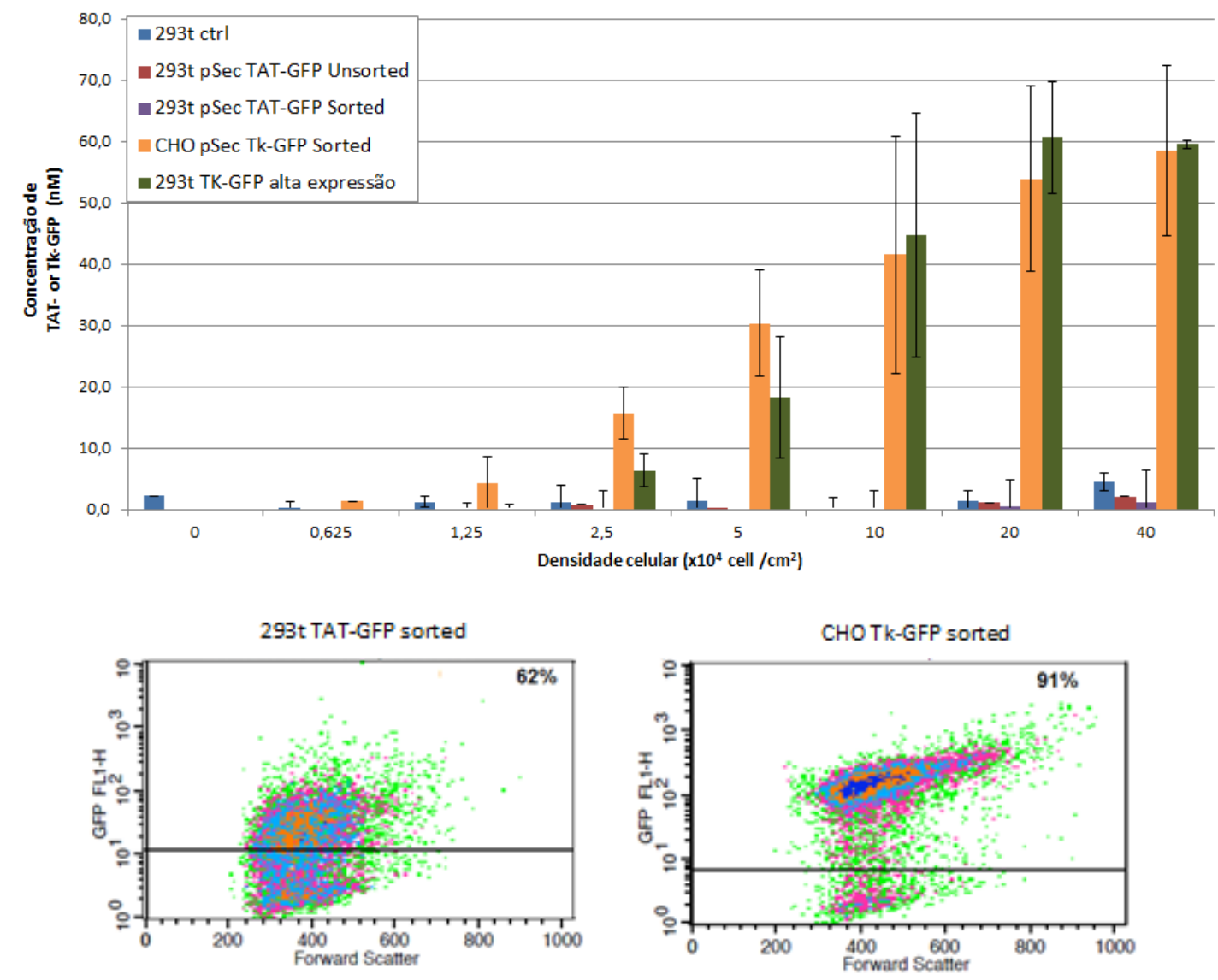

Figura 34: Comparação de produção de TAT-GFP e TATא-GFP nas células 293t. (A) Nível de produção e secreção de TAT-GFP versus TATк-GFP em células 293t e CHO transfectadas e separadas por citômetro de fluxo. Nenhum sinal significativo é obtido, mesmo depois da separação das células 293t TAT-GFP ${ }^{+}$no citômetro de fluxo. (B) Density plot representativos de populações 293t TAT-GFP e CHO-TATкGFP separadas por citometria de fluxo após alguns dias da separação. ( $\mathrm{n}=1$ para $\mathrm{CHO}$ e $\mathrm{n}=3$ para os demais)

\subsection{Tentativas de reprogramação usando o sistema TATא}

Assim que terminou a etapa de seleção das linhagens produtoras de fatores, sempre em paralelo, células MEF, fibroblastos de pele humanos e células mesenquimais de tecido adiposo humano foram postas em contato com as células produtoras por dois métodos: passando o meio de cultura condicionado a cada 24 horas ou usando transwell com trocas de meio a cada $24 \mathrm{~h}$. Isso foi realizado ainda 
sem saber se elas estavam produzindo quantidades significativas de proteína, mas a intenção aqui foi antever possíveis problemas da co-cultura ao se tentar a reprogramação.

\subsubsection{Transferindo meio condicionado}

A simples estratégia de condicionar o meio de cultura de uma mistura das quatro diferentes linhagens de células CHO e 293A produtoras (OSKM em iguais proporções, total de $10 \times 10^{4}$ células $/ \mathrm{cm}^{2}$, condicionando por $24 \mathrm{~h}$ ), seguido da centrifugação para remover possíveis células flutuantes foi realizada na tentativa de reprogramar MEFs ou fibroblastos da pele de humanos. O processo de troca de meio foi repetido a cada 24 horas. Imagens representativas das células que foram tratadas por quase um mês são apresentadas (Figura 35). 


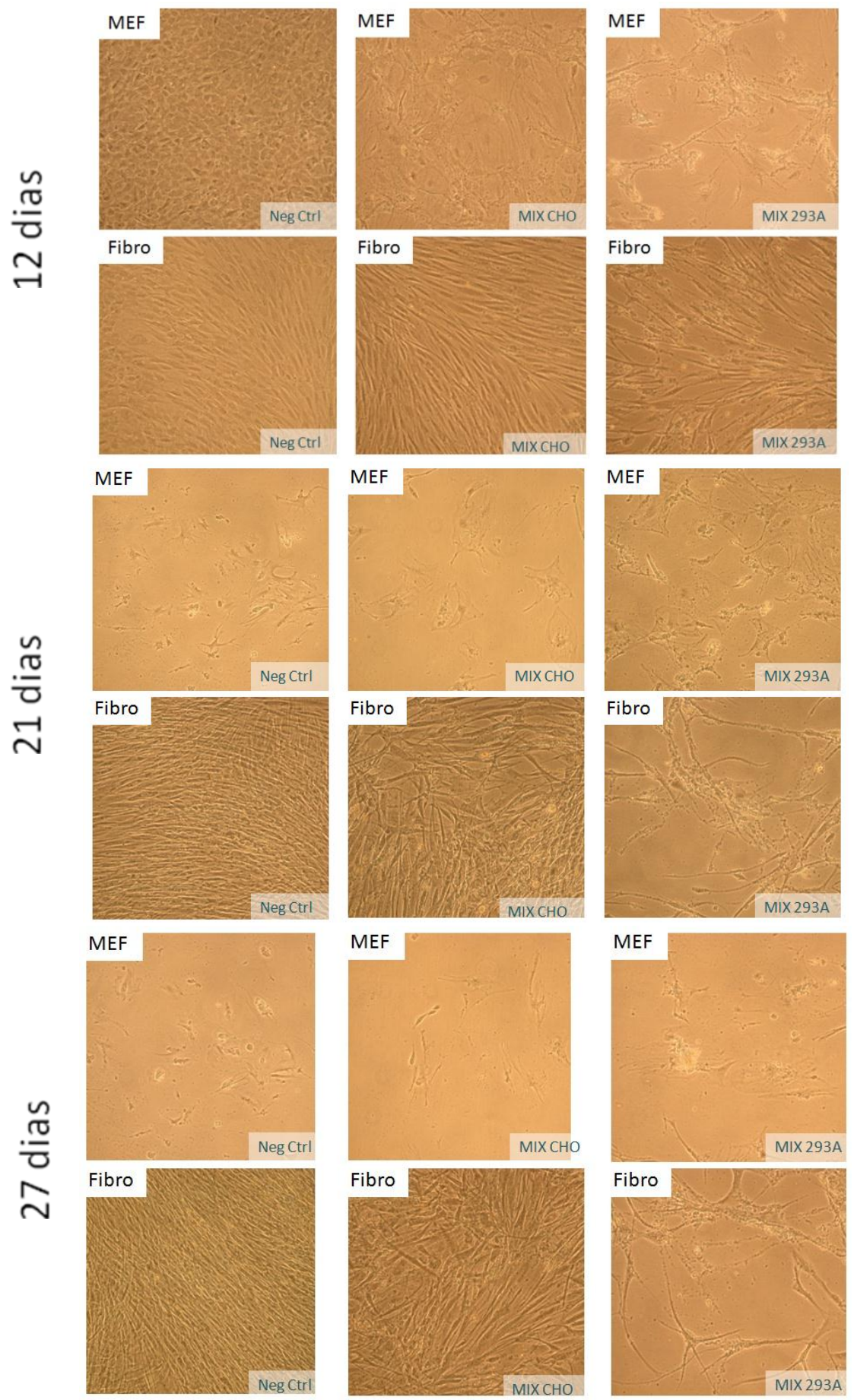

Figura 35: Imagens representativas de uma placa de seis poços com MEF e HFF tratado com meio condicionado derivado de CHO e 293A-TAT $\mathrm{C}$-fatores.

O meio condicionado foi diluído com meio fresco (50:50) e transferidos a cada $24 \mathrm{~h}$. Observe a extensão da morte celular, principalmente no poço contendo MEF ( $\mathrm{N}=6$, aumento de 100x).

Houve significativa morte celular nas células MEF após 10-12 dias, especialmente aqueles que estavam recebendo meio condicionado de 293A-TATא- 
fatores. Os fibroblastos humanos resistiram por mais algum tempo, mas aqueles poços que receberam 293A-TATא-fatores também morreram depois de um mês. Uma diluição mais elevada (30:70 sendo meio condicionado: meio fresco) também foi testada. Apesar da menor incidência de morte celular, nenhuma colónia iPS-like foi observada após 30 dias (dados não mostrados).

\subsubsection{Co-cultura utilizando o Transwell $^{\circledR}$}

Experimentos de co-cultura foram realizados utilizando transwells de 1 e $3 \mu \mathrm{m}$, que supostamente são pequenos o suficiente para evitar migração celular através de seus poros. Foi usada uma mistura de células 293t-TATк-SOX, KLF-e-MYC com 293A-TATк-OCT plaqueadas $\left(1 \times 10^{5}\right.$ cells $/ \mathrm{cm}^{2}$, na câmara superior $)$ em uma proporção que os fatores todos fosse secretados a concentração estimada de 53ng/mL, baseado nas dosagens anteriores (Tabela 3). O meio de cultura foi trocado a cada 24 horas. No compartimento inferior foram plaqueadas células MEF-Ds.RED derivada de um camundongo transgênico DS.Red $\left(1 \times 10^{4}\right.$ cells $\left./ \mathrm{cm}^{2}\right)$. Ainda que as células produtoras teoricamente não pudessem atravessar os poros do transwell, elas estariam recebendo os quatro fatores e poderiam se reprogramar. Se houvesse algum tipo de contaminação, a interpretação estaria comprometida. Da maneira que foi montado o experimento, se qualquer colônia com capacidade de fluorescer em canal vermelho (ao microscópio de fluorescência) com morfologia semelhante a miPS aparecesse, seria indubtavelmente derivada da MEF, e não a partir das células produtoras.

Como resultado, não foi observado colônias semelhantes às iPS e as célulasalvo começaram a morrer em cerca de 6-7 dias do início da co-cultura, similar à 
abordagem anterior, com passagem de meio. $\mathrm{O}$ aspecto que chama mais chama a atenção é a acidificação do meio de cultura tão rápido quanto 24 horas de condicionamento. $\mathrm{Na}$ medida em que as células produtoras são plaqueadas, o consumo do meio aumenta rapidamente e pode ser observada uma mudança na sua cor pelo indicador de $\mathrm{pH}$ Phenol Red, tornando-se visivelmente mais amarelado. No entanto, o meio de cultura que está no compartimento inferior de transwell não está exatamente com a mesma cor, indicando que a perfusão possivelmente não é completa (Figura 36).

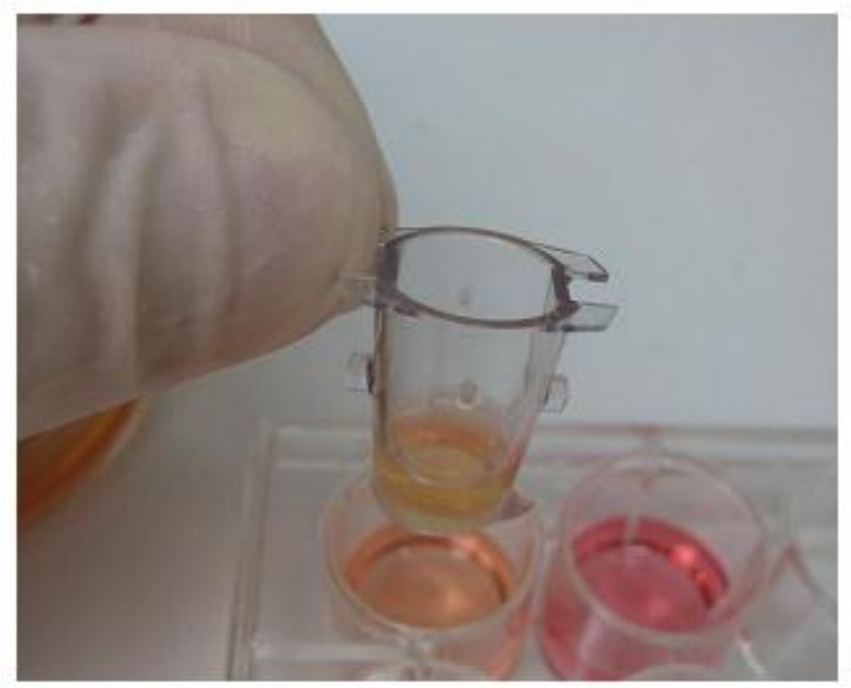

Figura 36: Imagem representativa da acidificação do meio de célula em transwell de $1 \mu \mathrm{m}\left(10 \times 10^{4}\right.$ cels $/ \mathrm{cm}^{2}, 24$ horas $)$ por células de produção.

$\mathrm{O}$ poço da direita não teve nenhum contato com as células de produção e tem a coloração normal. Além disso, o meio que está no compartimento inferior de transwell não está com a mesma cor, indicando que a perfusão possivelmente não está completa.

Como não houve a geração de colônias de iPS tendo o sistema TATк sido já padronizado e validado, passou-se a verificação da transdução das proteínas TATкGFP em transwell de poro de $3 \mu \mathrm{m}$ (Figura 37). Esse tamanho foi escolhido por ser pequeno o suficiente para evitar migração de células ao compartimento inferior. 

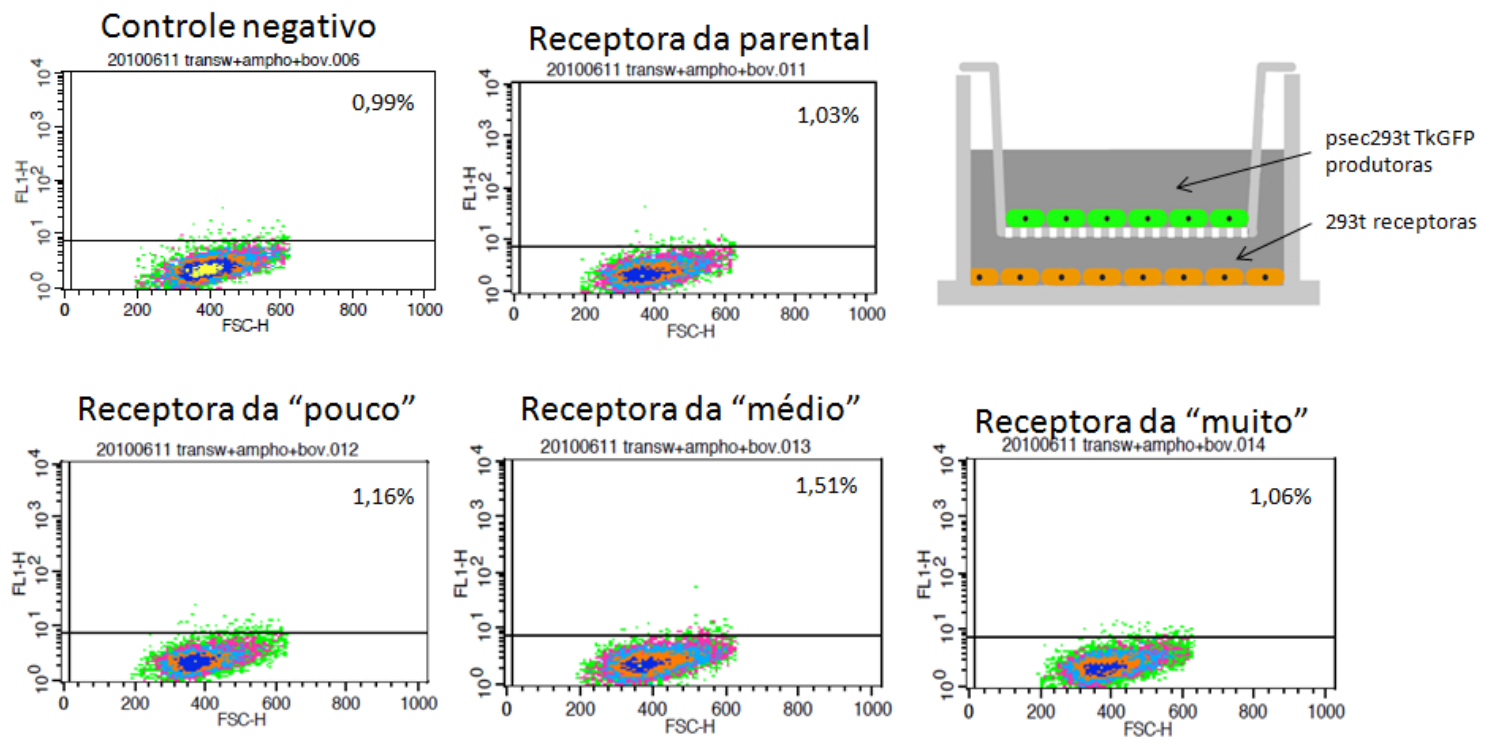

Figura 37: Co-cultura utilizando transwell de $3 \mu \mathrm{m}$ das diferentes populações de células 293t-pSec-TATк-GFP separadas por citometria de fluxo.

Density plots representativos da intensidade de fluorescência verde (GFP) versus tamanho celular (Forward Scatter, FSC) obtidos após co-cultura de células 293t

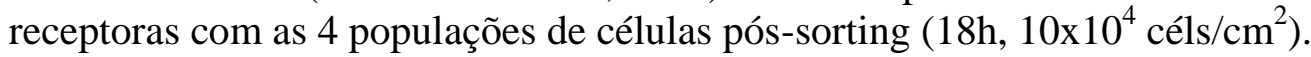

Como pode ser observado, não há alteração significativa da porcentagem de células verdes, tampouco na intensidade de fluorescência média (MFI) das células receptoras. Isso pode ser parcialmente explicado pela concentração de TATא-GFP presentes no meio celular (uma vez que a quantidade necessária de meio de celular por transwell é desfavorável). Embora esta seja a melhor condição de célula/área para produzir um meio condicionado com detectável fluorímetro, talvez ainda seja uma baixa concentração para conseguir alterar o nível de fluorescência das células e ser detectável no citômetro de fluxo. Outra hipótese seria problemas na permeabilidade do transwell. Conseqüentemente procurou-se investigar a

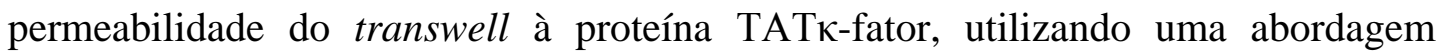
adaptada a partir da literatura ${ }^{112}$. Células 293t-TATк-GFP foram plaqueadas no compartimento superior e o meio coletado a cada 24 horas de ambos compartimentos (Figura 38). A razão de concentração de TATк-GFP que está na câmara baixa em 
relação ao que está na câmara de cima é denominada fluxo e está bastante baixa, mesmo com períodos de até quatro dias sem troca de meio. Uma vez que é necessário realizar trocas diárias de meio para minimizar a morte celular, esta abordagem transwell parece ser ineficiente para realizar a reprogramação nuclear, apesar do seu sucesso em outras aplicações, tais como entrega de drogas ${ }^{113}$, vírus ${ }^{75}$ e citocinas ${ }^{114}$.

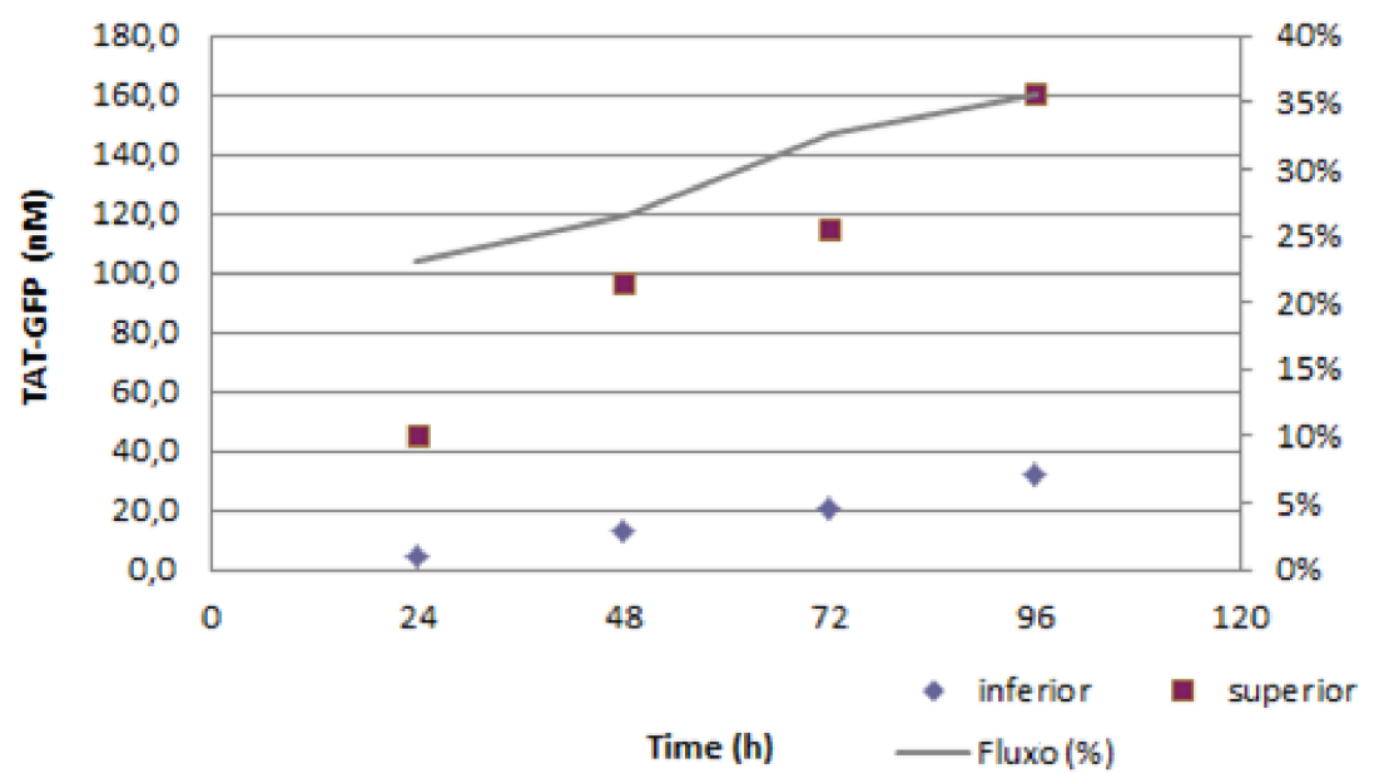

Figure 38: Verificação da permeabilidade de TATк-GFP através da membrana $3 \mu \mathrm{m}$ do sistema transwell em função do tempo.

$\mathrm{Na}$ medida em que as proteínas são produzidas, elas passam através da membrana para o compartimento inferior, porém, com baixa eficiência.

\subsubsection{Co-cultura usando microcápsulas}

A fim de contornar as limitações anteriores, cogitou-se a possibilidade de usar outro sistema de co-cultura, baseado em microcápsulas. Ela teria a vantagem de permitr pôr em contato as células produtoras e receptoras de maneira supostamente mais eficiente ${ }^{73}$. Contudo, esse sistema de encapsulamento requer que as células apresentem baixos ou preferencialmente nulos índices de proliferação para evitar ter 
que reencapsular as células com frequência e tornar o projeto viável do ponto de visto de custo. Portanto, primeiramente foi investigada a possibilidade de redução ou cessação da proliferação celular das culturas de células produtoras já estabelecidas por meio do tratamento de irradiação- $\gamma^{115}$ ou mitomicina $C^{88}$.

Num primeiro experimento com irradiação, doses de 2, 10 e 20 Gy foram utilizadas, partindo-se da referência de utilização em um outro tipo de linhagem tumoral, a DU145 (Figura 39). Além disso, foi realizado ensaio de ELISA para checar a produção de TATк-OCT imediatamente após a irradiação $\left(24 \mathrm{~h}, 10 \times 10^{4}\right.$ cells $/ \mathrm{cm}^{2}$ ) e evidenciou-se uma redução significativa na taxa de produção de proteínas nas doses de 10 e 20 Gy, provavelmente por haver grande efeito de morte celular. A morte celular fica também evidente sob o microscópio após mais alguns dias do tratamento. Tentou-se usar doses mais baixas (2, 4 e 6 Gy) em uma segunda tentativa. Essas doses de 2-6 Grays não promoveram diminuição significativa da produção de TATк-OCT nem foi observado morte celular significativa, no entanto, as células continuam a proliferar como o controle (verificado por ensaio de MTT, dados não mostrados). Como alternativa, tentou-se utilizar a mitomicina $\mathrm{C}$, de maneira análoga ao que é feito com MEFs para promover uma diminuição da proliferação, mas o resultado também não foi satisfatório. 
A)
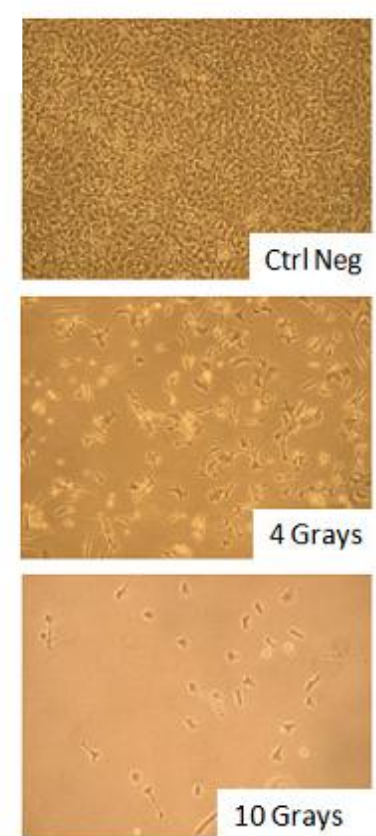

D)
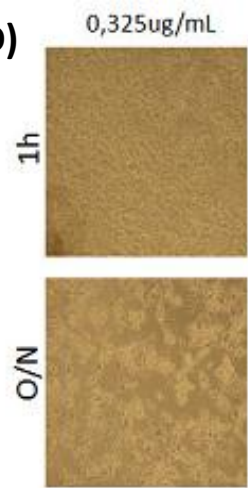

$0,75 \mathrm{ug} / \mathrm{mL}$
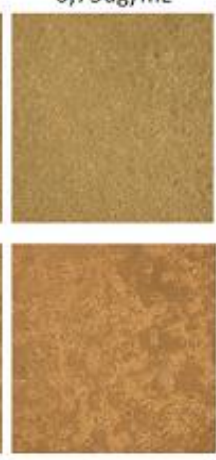
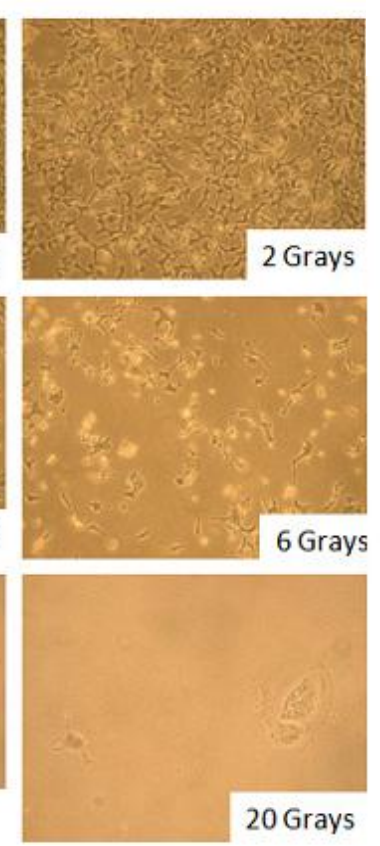

B)
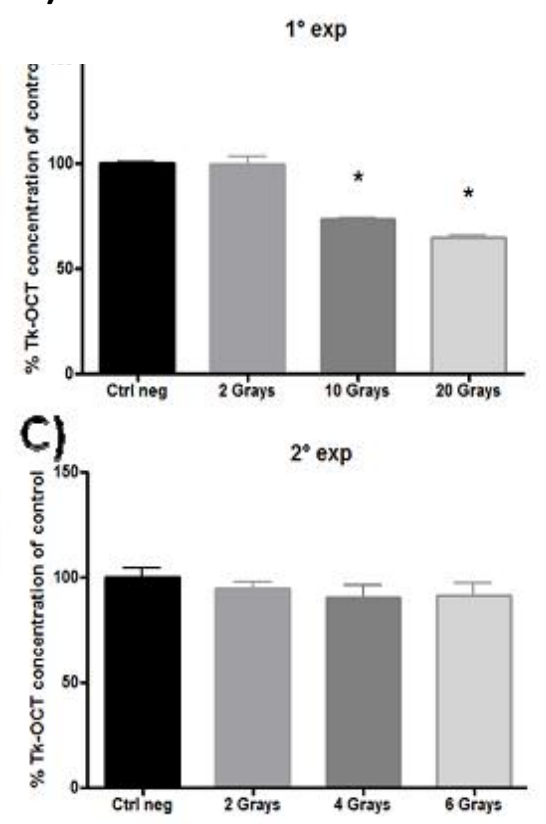

$3 \mathrm{ug} / \mathrm{mL}$

$12 \mathrm{ug} / \mathrm{mL}$
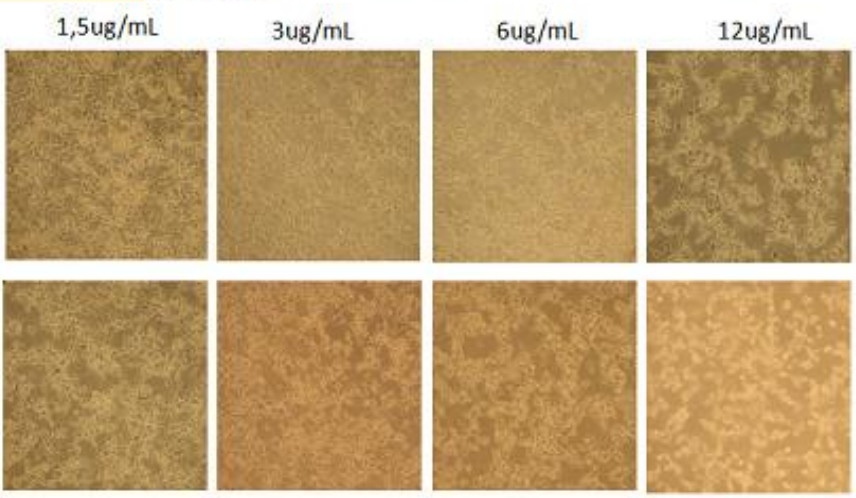

Figura 39: Tratamento com radiação gama em células na linhagem 293A-TATкOCT induz morte celular.

(A) Imagens representativas da cultura de células após 10 dias da irradiação. Note que o número de células remanescentes é inversamente proporcional à dose utilizada, devido à extensa morte celular (aumento 100x). Avaliação da produção e secreção de TATк-OCT por $24 \mathrm{~h}$, dois dias após a irradiação nos lotes de maior $(\mathbf{B})$ e menor $(\mathbf{C})$ doses de irradiação. (* Indica ANOVA com Bonferroni post hoc $\mathrm{p}<0,05, \mathrm{n}=2$ ). (D) Efeito da mitomicina C em 293A-TATк-OCT linhagem. Morte celular é observada com o uso de doses acima de $1,5 \mu \mathrm{g} / \mathrm{mL}$ por 1 hora ou durante a noite, em qualquer dose.

Em aproximadamente duas semanas todas as células dos poços de concentração maior do que $0,75 \mu \mathrm{g} / \mathrm{mL}$ de mitomicina $\mathrm{C}$ morreram. 
Olhando mais atentamente na literatura, é possível observar que, ao contrário das células normais expostas à radiação (que apresentam parada de ciclo celular em G1/S e G2/M), células cancerosas são propensas à morte celular por radiação no final da fase G2, principalmente se elas apresentam o gene P53 mutado ${ }^{116}$. Em geral, as células ou reparam o dano na parada de ciclo e voltam a proliferar ou morrem, dependendo da extensão do dano causado pela irradiação. Células HEK-293A não expressam p53 em condição basal ${ }^{117}$, mas passam a apresentá-lo na forma nativa se estimuladas, o que justifica a tentativa de parada de ciclo celular dessas células ${ }^{118}$. Porém as células 293A são transformadas com sequência de adenovírus (região E1, contendo os genes E1a e E1b). O gene E1a inativa Rb e o gene E1b inativa p53. Portanto, provavelmente a falta de parada pós irradiação esteja relacionada com a falta de $\mathrm{Rb}$ funcional e da atividade da p53. Este mecanismo é mais sutil do que a morte celular. É comum células com Rb inativado passarem a superexpressar p16.

Em conclusão, ainda que sejam boas candidatas por apresentarem grandes taxas de produção dos fatores, a linhagem 293 apresenta como limitação, para esse sistema de microcápsulas, a impossibilidade de parada do ciclo celular de maneira definitiva. Alternativamente, procurou-se verificar a possibilidade de reprogramação concentrando-se o meio sobrenadante usando colunas Amicon.

\subsubsection{Aumentando a concentração das proteínas usando colunas Amicon}

Uma vez que o principal fator limitante para o sucesso na reprogramação

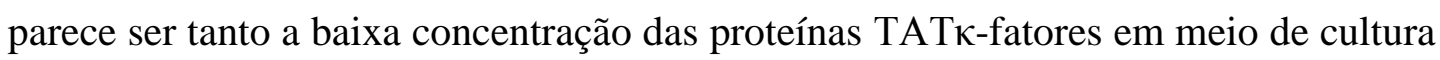
como a baixa quantidade de nutrientes e alta de metabólitos (lactato e amônio) devido ao consumo do meio de cultura (conforme pode se observar pela alteração da 
cor do meio; Figura 36), decidiu-se concentrar o material utilizando colunas Amicon (Millipore, para proteínas de até $10 \mathrm{KDa}$ ). Centrifugando o meio de cultura nessas colunas é possível aumentar a concentração de proteínas em até 100 vezes em relação à concentração inicial. Uma vez concentrado, o material pode ser armazenado em freezer $-80^{\circ} \mathrm{C}$ ou utilizado de imediato nas células. Para aumentar a eficiência, planejaram-se experimentos onde as células receberam o tratamento das primeiras horas logo em suspensão, de forma a maximizar a superfície de contato, incubados a $37^{\circ} \mathrm{C}$. De forma a verificar se esse método é eficaz o suficiente, procurou-se promover um experimento de concentração das proteínas TATk-GFP produzidas pelas células 293t-TATк-GFP e na sequencia células MEF foram tratadas por diferentes intervalos de tempo com elas e avaliadas no dia seguinte por citometria de fluxo. (Figura 40). 


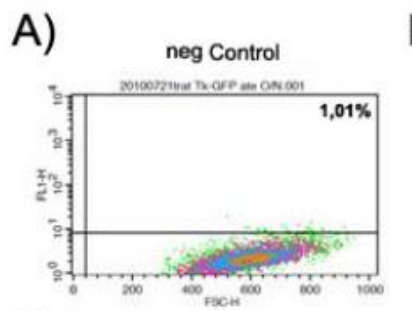

F)

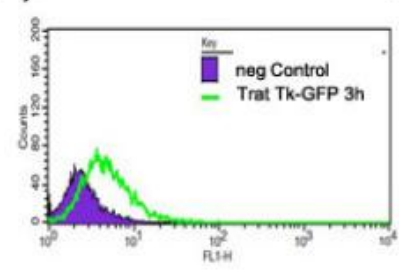

B)

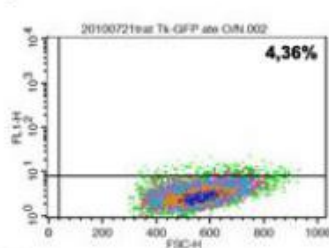

D)

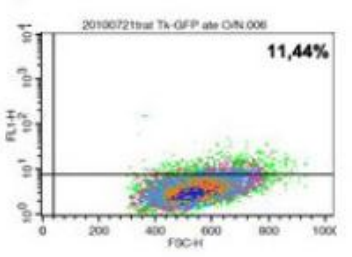

C) $\quad 1 \mathrm{~h}$

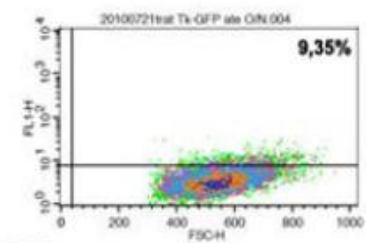

E)

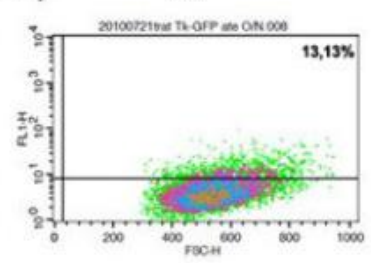

G)

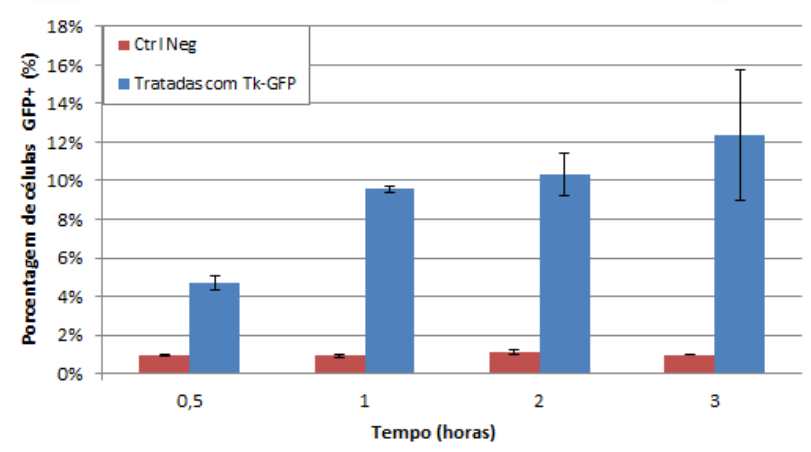

Figura 40: TATк-GFP concentrada é capaz de entrar nas células e ser detectável por citometria de fluxo.

Células MEF na segunda passagem foram tratadas com em suspensão $1 \mu \mathrm{M}$ de

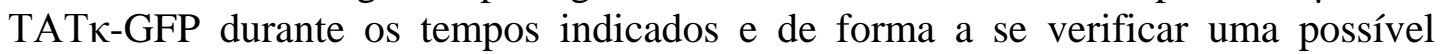
relação tempo-dependente na porcentagem de células marcadas. Density plots de (A) controle negativo, e células MEF tratadas após (B) 30 minutos, (C) 1 hora (D) duas horas, (E) três horas. (F) Histograma da célula no canal FL1, após o tratamento em suspensão por 3 horas demonstra uma diferença significativa entre as populações tratadas e controle negativo. (G) Representação gráfica da porcentagem de células fluorescentes em função do tempo. $(\mathrm{N}=2)$

Pode-se notar que a absorção de proteína apresenta uma relação tempo dependente na porcentagem de células que podem ser verdadeiramente consideradas $\mathrm{GFP}^{+}$. Além disso, diferentemente do que foi observado com a proteína rTAT-GFP (Figura 24) não há morte celular significativa, mesmo com tempo maior de tratamento (até 12h; dados não mostrados), indicando que não existem moléculas maiores do que $10 \mathrm{kDa}$ promovam a morte celular, como observado ao utilizar o 
sistema transwell. Após estes encorajadores resultados, foi conduzida uma grande série de sete experimentos independentes promovendo-se o tratamento das células com meio condicionado concentrado produzido por linhagens produtoras (plaqueadas na densidade de $10 \times 10^{4}$ células $/ \mathrm{cm}^{2}$, por 24 ou 48h; Figura 41). Nesses experimentos, na condição de $3 \%$ de $\mathrm{O}_{2}$, procurou-se também variar a proporção entre os fatores (triplicando-se a quantidade de OCT em relação aos demais) bem como o tipo de célula receptora e sua passagem, o tempo em suspensão, a presença ou não de ácido valpróico e o número de vezes que a troca de meio foi feita. Um sumário dessas combinações é apresentado na figura 41B. Além disso, os cálculos para estabelecer a referência da quantidade de proteína foram realizados a partir de das concentrações estimadas de ELISA ou por quantidade total de proteína por Bradford. Algumas placas foram acompanhadas com trocas diárias de meio por até 72 dias. 
A)

Tripsinização
Replaqueamento nofeeder após 8 dias
B)

\begin{tabular}{|c|c|c|}
\hline & com VPA 7 dias? & Número tentativas \\
\hline \multirow{2}{*}{ produtoras mix 1:1:1:1 } & $\operatorname{sim}$ & 1 \\
\cline { 2 - 3 } & não & 2 \\
\hline \multirow{2}{*}{ prot 1:1:1:1 } & $\operatorname{sim}$ & 7 \\
\cline { 2 - 3 } & não & 2 \\
\hline \multirow{2}{*}{ prot 3:1:1:1 } & $\operatorname{sim}$ & 6 \\
\cline { 2 - 3 } & não & 2 \\
\hline \multirow{2}{*}{ elisa 1:1:1:1 } & sim & 2 \\
\cline { 2 - 3 } & não & 2 \\
\hline \multirow{2}{*}{ Elisa 3:1:1:1 } & sim & 4 \\
\cline { 2 - 3 } & não & 1 \\
\hline \multirow{2}{*}{ Total } & - & 29 \\
\hline
\end{tabular}

\begin{tabular}{|l|l|}
\hline Tipos de células já testadas & Passagem \\
\hline hASC & $\mathrm{P} 1, \mathrm{P} 5$ \\
\hline MEF & $\mathrm{P} 2, \mathrm{P} 3$ \\
\hline MEF Ds.RED & $\mathrm{P} 2, \mathrm{P} 5$ \\
\hline Fibro cardíaco & $\mathrm{P} 1, \mathrm{P} 5$ \\
\hline
\end{tabular}

\begin{tabular}{|c|c|}
\hline Tempo tratamento & Número de tentativas \\
\hline 3h Suspensão & 3 \\
\hline 7h suspensão & 3 \\
\hline 18h suspensão & 9 \\
\hline 24h suspensão & 1 \\
\hline 24h aderida & 8 \\
\hline
\end{tabular}

C)

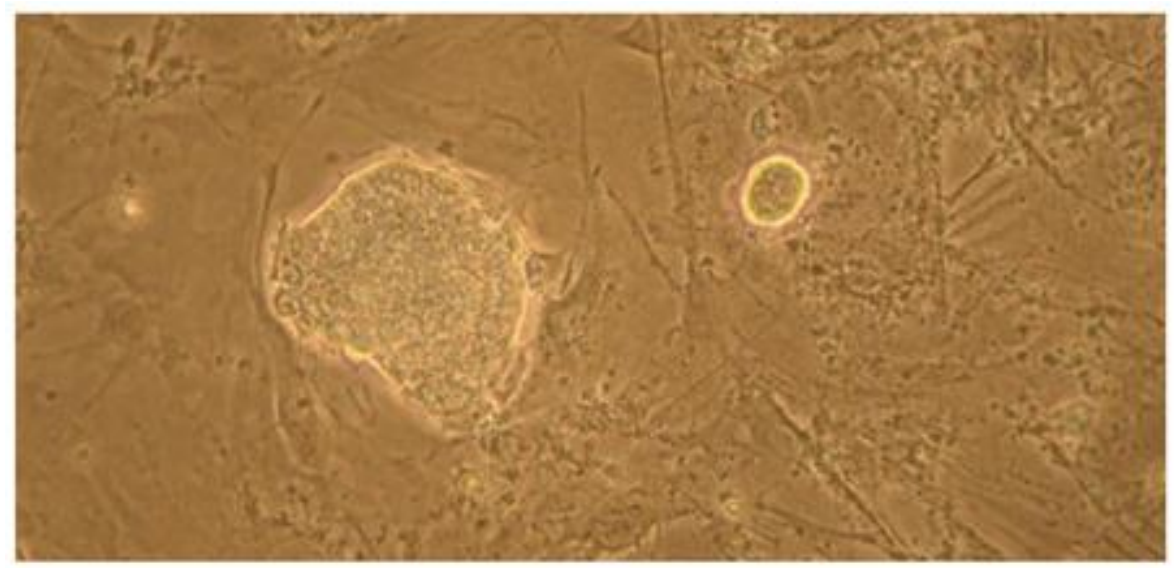

Figura 41: Tentativas com meio de cultura concentrado para reprogramar células ao estado pluripotente.

Concentrada TAT-k-fatores foram utilizados para tratar em suspensão MEF, fibroblastos de pele humanos ou hASC durante os tempos indicados. (A) esquema de tratamento proposto. (B) Resumo das tentativas para reprogramar usando essa abordagem $(\mathbf{C})$ imagem representativa da colônia que emergiu após 20 dias do início do tratamento que apresentou a morfologia mais próxima da esperada para uma mIPS (Aumento de 200x).

Dessa vez, colônias com morfologia bastante semelhantes às células miPS apareceram nas placas, particularmente quando se utilizou uma mistura de 50:50 de meio condicionado concentrada médio e fresco, após trocas diárias por do meio com proteínas 14 dias e o acompanhamento da placa por 30 dias (Figura 41C). O ensaio de coloração de fosfatase alcalina e RT-PCR para marcadores de pluripotência 
mostraram que estas colônias são falso-positivo. Outras tentativas foram feitas e não foi possível alcançar resultados favoráveis, sugerindo que pode haver ainda outros fatores complicadores. Outra possibilidade seria que alguma das proteínas estivesse com problemas, mas não necessariamente todas.

Em um esforço para melhor compreender e controlar o processo de reprogramação celular, uma nova série de experimentos foi planejada com MEFs. A partir desse momento as células humanas não foram mais utilizadas, dada a sua maior complexidade na reprogramação. Nesse experimento, antes de iniciar o tratamento com os quatro fatores de transcrição, foi realizada a infecção com retrovírus na tentativa de observar o efeito de cada TATк-proteína independentemente. Ou seja, as células foram infectadas por pelo menos três retrovírus (por exemplo, OCT, KLF e MYC) e o fator de transcrição em falta (neste caso, SOX) foi complementado com o meio de cultura condicionado e concentrado. Como controle positivo foi realizada uma placa com os quatro retrovírus (OSKM) mais eGFP e como controle negativo foi utilizada células infectadas com retrovírus eGFP apenas (importante para estimar a eficiência de infecção; (Figura 42).

Sete experimentos foram realizados. Em quatro deles foi observada uma alta taxa de infecção (superior a 80\%) e houve formação de colônias depois de 20 dias. Em todas as combinações, exceto quando TATк-OCT foi complementado, 2-3 colônias surgiram por poço. No entanto, novamente, eles não eram miPS verdadeiras. Diferentemente do controle positivo e do poço onde foram utilizados os vírus OSK complementado com TATк-MYC, elas não eram positivas para fosfatase alcalina e também não proliferaram depois de repicadas (Figura 42C). Para melhor avaliar a complementação com TATк-MYC seria necessário ter incluído o controle de apenas 
os 3 vírus OSK e comparado em termos de eficiência de reprogramação e de tamanho das colônias se a complementação do TATк-MYC foi efetiva.

A)

$$
\begin{array}{rlrl}
\text { Tripsinização } \stackrel{24 \mathrm{~h}}{\longrightarrow} & \begin{array}{l}
\text { Infecção } \\
\text { retrovirus } \\
- \text { Placa de }
\end{array} \\
& 6 \text { poços } & \text { dias } & \text { Plaqueamento } \\
\text { no feeder }- & \text { Placas de } 12 \\
\text { poços }
\end{array}
$$

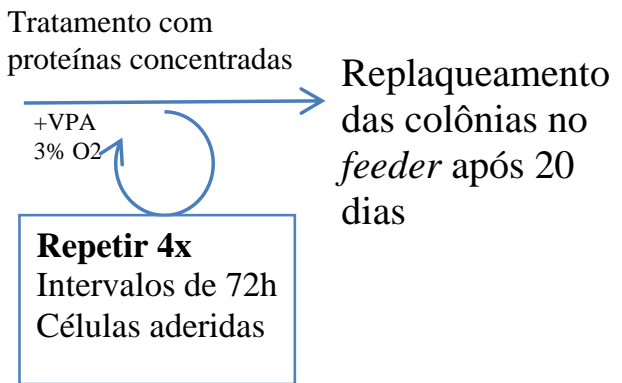

B)

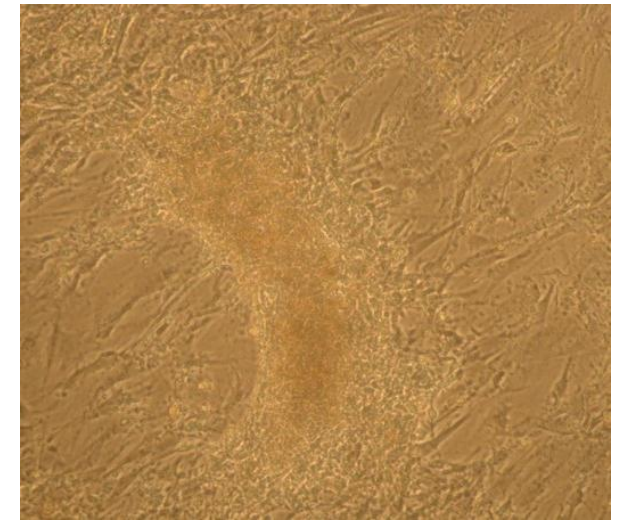

C)
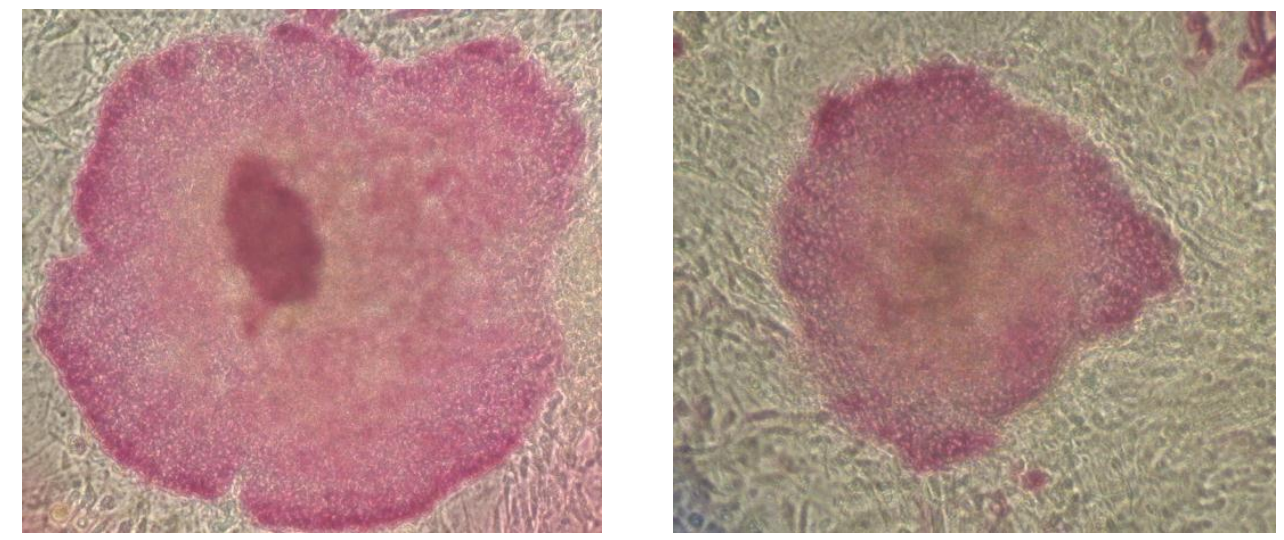

Figura 42: Verificação do funcionamento das TATк-proteínas independentemente.

(A) Representação esquemática do esquema de tratamento da última abordagem para a obtenção das células TATא-iPS. (B) imagem representativa de uma colônia que surgiu e é fosfatase alcalina negativa após 20 dias do início do novo tratamento. (C) Imagens representativas de colônias verdadeiras que surgiram no controle positivo (Aumento de 100x). 


\subsection{Influência do $B C S$ na diferenciação celular}

Aumento na taxa de proliferação de células ES ${ }^{119}$, na eficiência de clonagem de células ES de embriões ${ }^{120}$ e na eficiência de geração de iPS (quatro vezes maior; ${ }^{121}$ ) pode ser obtida quando se utiliza condições de cultura livre de soro, usando KSR ao invés de soro bovino (FBS ou BCS). Nesse trabalho, para efetuar a produção das proteínas as células produtoras foram mantidas em meio suplementado com $3 \%$ BCS e a utilização de Amicon para concentrar o meio de cultura condicionado também concentrava o BCS. De maneira a evidenciar o efeito do BCS nas células miPS produzidas usando retrovírus, foi realizado um experimento onde foram cultivadas as células sem KSR e, no seu lugar, foi suplementado 15\% BCS (sempre na ausência de feeder). Pode-se notar uma clara mudança na morfologia das células (as colônias perdem sua morfologia tridimensional, de coloração refringente, e adquirem um aspecto não refringente, onde as células estão mais individualizadas e os seus núcleos podem ser facilmente observados), logo após $24 \mathrm{~h}$, mesmo na presença de LIF

\section{(Figura 43).}
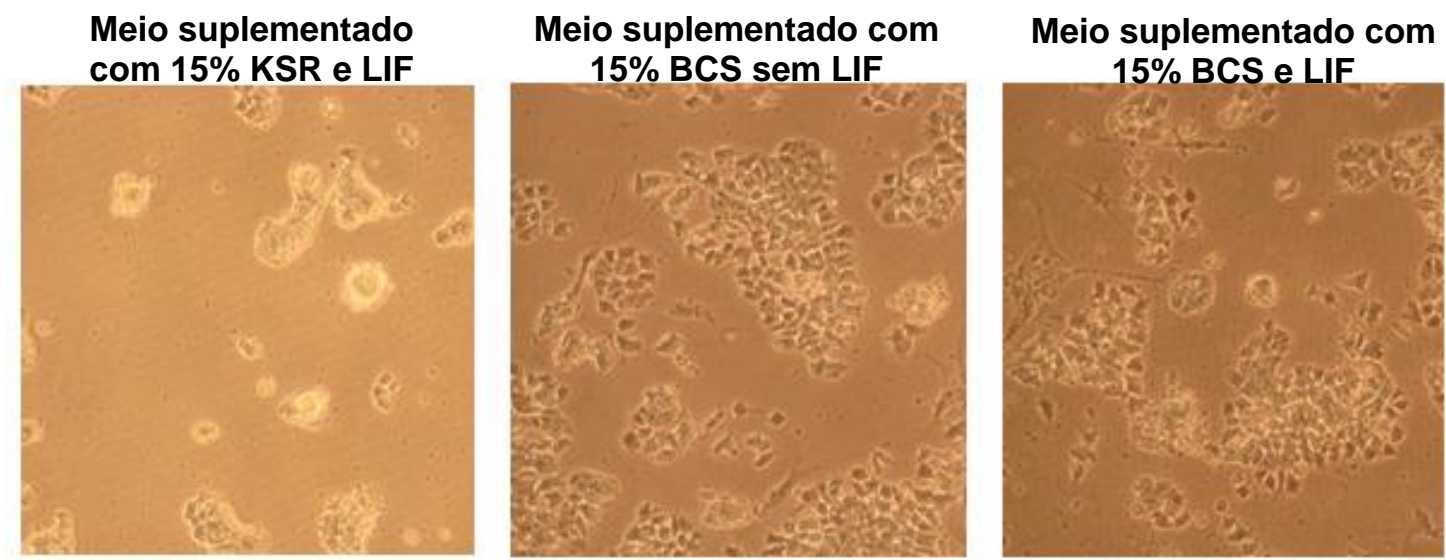

Figura 43: Células iPS sem camada feeder se diferenciam quando cultivadas na presença de $15 \%$ BCS, após $24 \mathrm{~h}$.

Da esquerda para a direita, imagens representativas da morfologia das células miPS após $24 \mathrm{~h}$ sendo cultivadas sem células feeder em meio completo ES celular; na ausência de $15 \%$ KSR mas na presença de $15 \%$ BCS com LIF e na ausência de $15 \%$ KSR e LIF mas na presença de $15 \%$ BCS. $(n=2$, aumento de 100x). 
De modo a resolver a possível interferência do BCS na reprogramação, as células 293t-TATא-fatores foram cultivadas em meio suplementado com $3 \%$ ou $10 \%$ KSR. Em ambas as condições, a proliferação celular foi muito prejudicada e as células começam a morrer, tornando inviável para a manutenção da cultura em longo prazo com este substituto do soro. Também se tentou cultivar as células em meio DMEM sem BCS, após dois ciclos de lavagem com PBS. Neste caso, a pior desvantagem é que as células começam a se soltar da placa e morrer já durante as lavagens.. Além disso, uma quantidade grande de BCS ainda estava presente na amostra podendo ser evidenciado em gel de poliacrilamida. Com a intenção de minimizar o efeito da depleção de cálcio e magnésio das lavagens com PBS, que facilita o desprendimento das células da placa durante as lavagens, procurou-se realizar essa etapa com "PBS+" (PBS suplementado com cálcio e magnésio), sendo possível realizar três ciclos de lavagens. Nesse caso uma significativa diminuição do BCS foi observada em gel de poliacrilamida corado com Coomassie Blue. No entanto, ainda havia um número grande de células foram flutuando depois de $24 \mathrm{~h}$ (Figura 44) e nessas condições a produção das proteínas ficaria comprometida. 
Método com lavagem usando PBS+

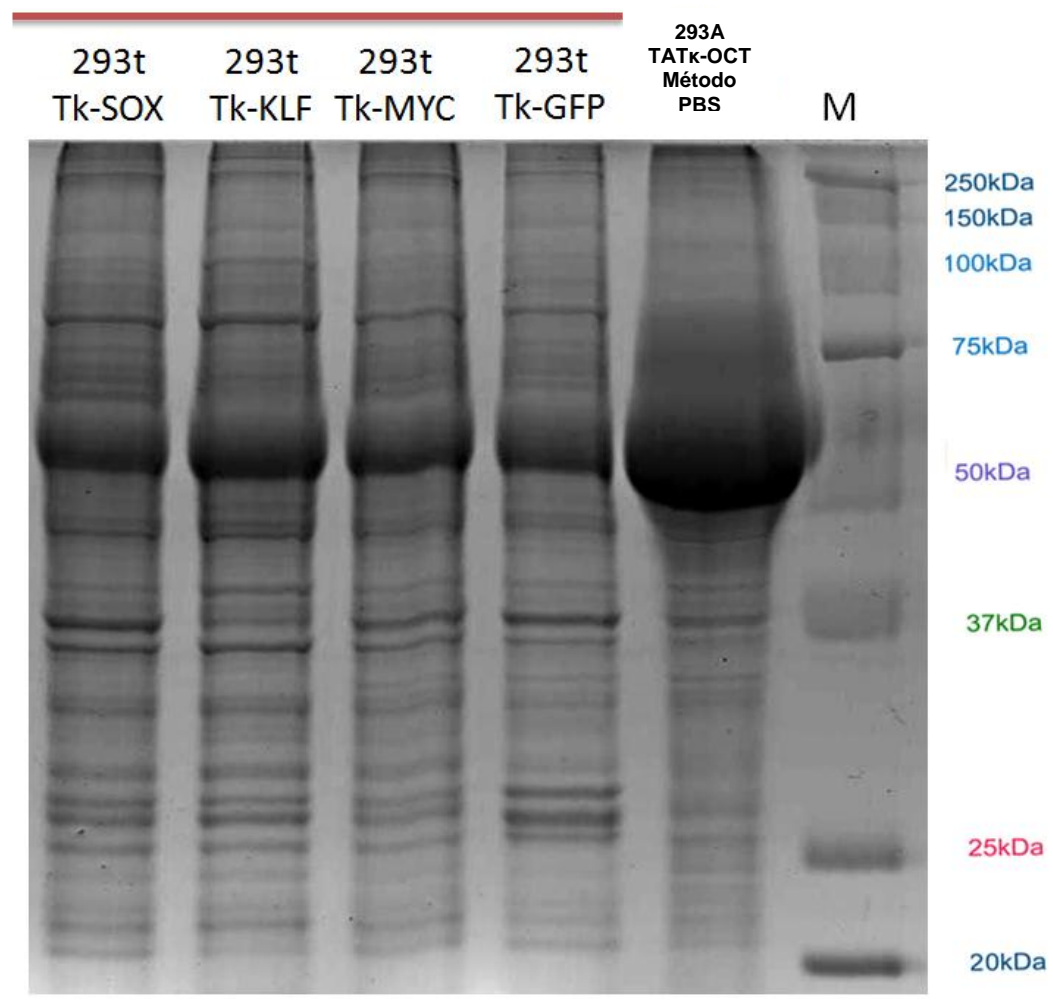

Figura 44: A presença de BCS no meio condicionado persiste mesmo após ciclos de lavagem com "PBS+".

Meio condicionado de 293t-TAT $\kappa$-fatores foi concentrado em colunas Amicon para a posterior visualização de proteínas por gel de poliacrilamida (por coloração Coomassie Blue). Note-se que as bandas de albumina $(\sim 60 \mathrm{KDa})$ e as demais derivadas do soro são muito reduzidas, mas ainda estão presentes.

De forma a entender qual era a porcentagem de BCS remanescente utilizandose essas abordagens, foi realizada uma associação da quantidade de proteína que estava presente no meio de cultura concentrado com a quantidade de proteína presente no BCS puro, utilizando-se a dosagem de proteínas por Bradford (Figura 45). 
A)

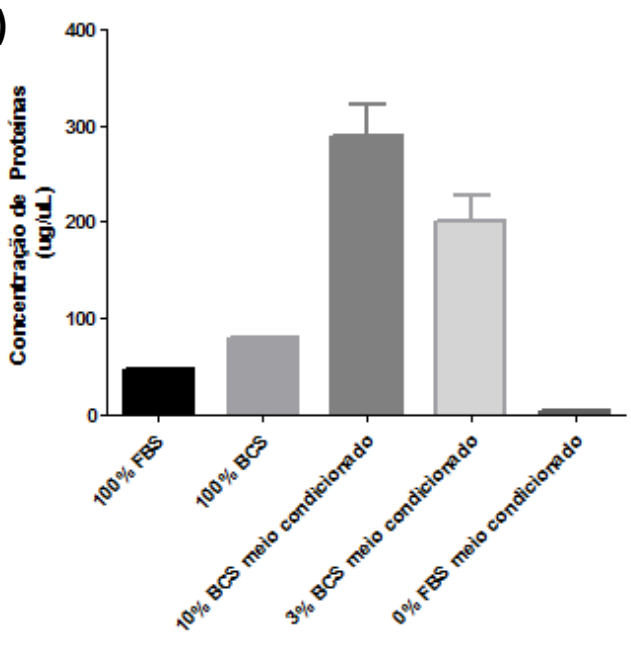

B)

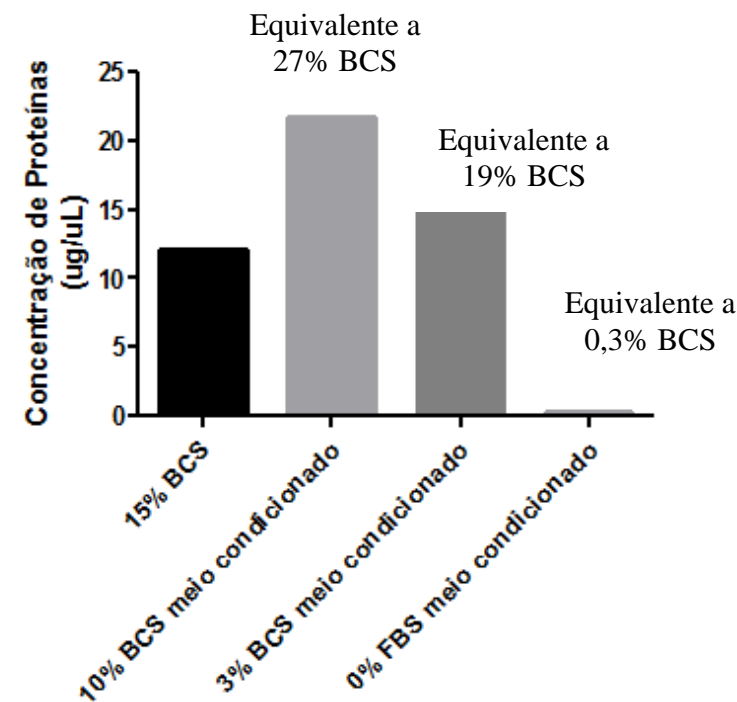

Figura 45: Associação entre BCS no meio condicionado concentrado e a quantidade de proteínas no BCS.

(A) Teor de proteína total foi analisado utilizando-se o método de Bradford para BCS puro e nos meios concentrado usando colunas Amicon partindo de concentrações iniciais de $10 \%, 3 \%$ e $0 \%$ de BCS $(\mathrm{n}=3)$. (B) Uma vez que foram utilizados cerca de $75 \mu \mathrm{L}$ do meio concentrado em $1 \mathrm{~mL}$ para o tratamento das células com vírus, é possível calcular a porcentagem de BCS final equivalente para cada condição.

Ao se concentrar um meio de cultura inicialmente com $10 \%$ BCS, e se realizar uma diluição de maneira análoga ao que vinha sendo feito no protocolo onde se utilizou vírus junto das proteínas (aproximadamente $75 \mu \mathrm{L}$ de proteína em $1 \mathrm{~mL}$ de solução) a solução final torna-se equivalente a $27 \%$ BCS. Partindo-se de $3 \%$ BCS inicial, um equivalente de 18,79\% BCS é obtido. Quando não é utilizado BCS na produção e lavagens com PBS+ são feitas, obtém-se um equivalente a 0,30\% de BCS residual. Essa última condição parece suficiente, contudo uma vez que as células não estarão em condições ideais para cultivo, procuraram-se maneiras alternativas de efetuar produção de proteínas na ausência de soro. 


\subsubsection{Adaptação das células produtoras à condição sem soro}

O soro bovino é necessário para a manutenção das propriedades de proliferação e aderência de células, no caso das células 293t. Quando há necessidade, a forma mais adequada para remover o soro da cultura é cultivar as células em um meio de cultura quimicamente definido (CDM, do inglês Chemically Defined Medium), com as células em suspensão. Contando com a colaboração da Dra. Elisabeth Pires Augusto do Instituto de Pesquisas Tecnológicas (IPT / USP), começou-se a adaptação de todas as linhagens produtoras de fator 293t e CHO (OSKM e GFP), submetendo as células a concentrações progressivamente menores de BCS (25\% menor a cada passagem). O meio de cultura utilizado rotineiramente (DMEM suplementado com 10\% BCS) foi gradualmente substituído por um meio quimicamente definido (CDM4-CHO, Invitrogen), ao qual não é adicionado soro bovino. O processo todo usualmente leva de 40 a 60 dias para garantir que a linhagem de célula continua proliferando de maneira estável e produzindo as proteínas recombinantes. A cada repique o número de células vivas e mortas é contabilizado utilizando-se tripan blue na Câmara de Neubauer de tal forma que quando acontece um número excessivo de morte celular, a quantidade de soro é mantida e se eventualmente o número de células viáveis se torna muito pequeno, o processo é reiniciado a partir de algum ponto anterior onde foi efetuado o congelamento das células. Abaixo são apresentados de maneira representativa os gráficos a partir dessas informações para as linhagens 293t e CHO-ТкOCT (Figura 46). 
A)

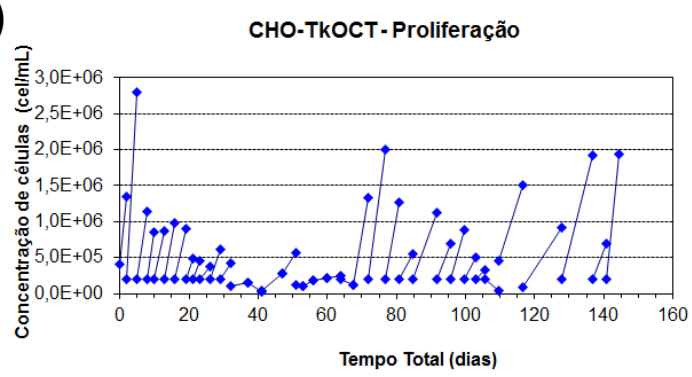

C)

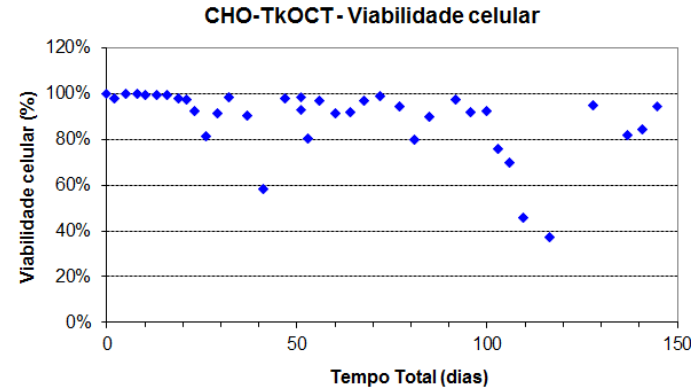

E)

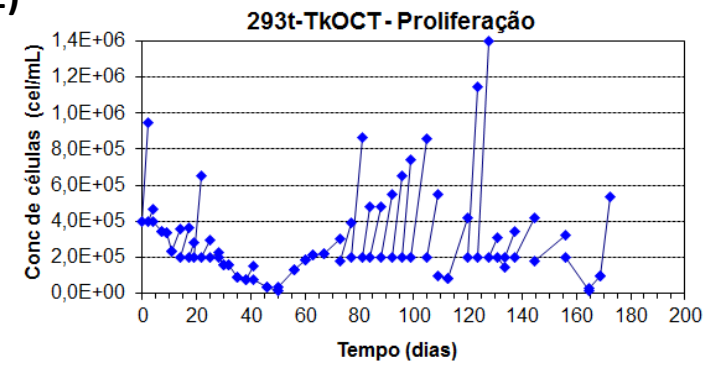

G)

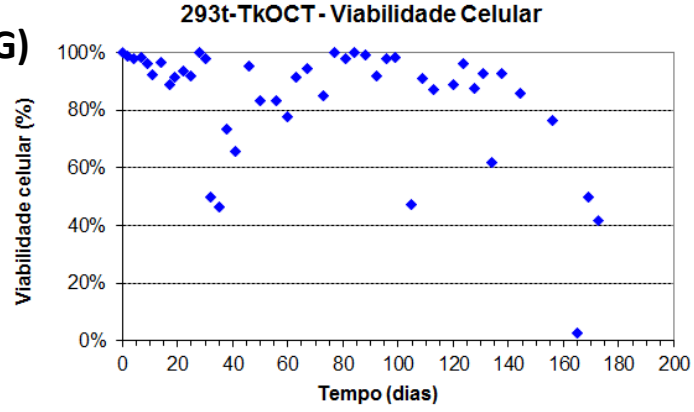

B)

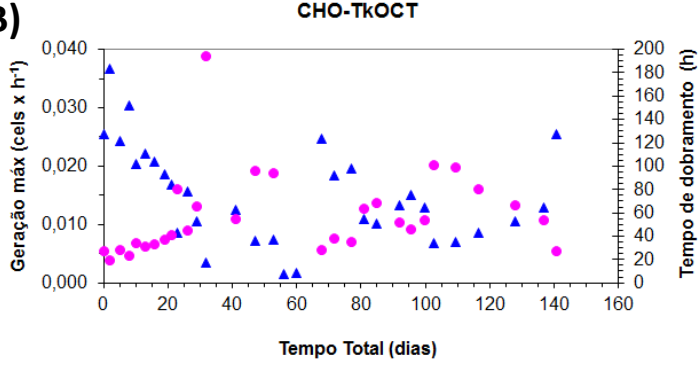

D)

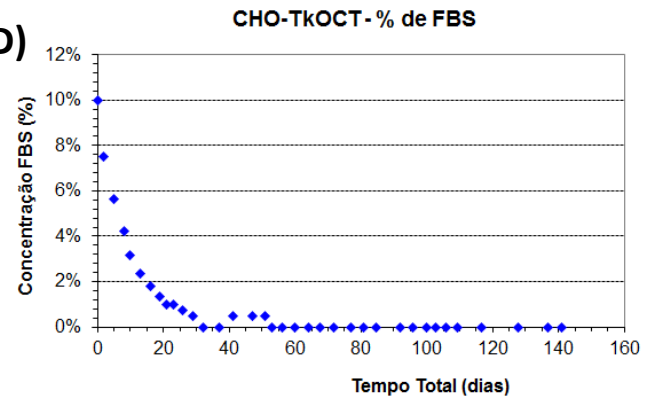

F)
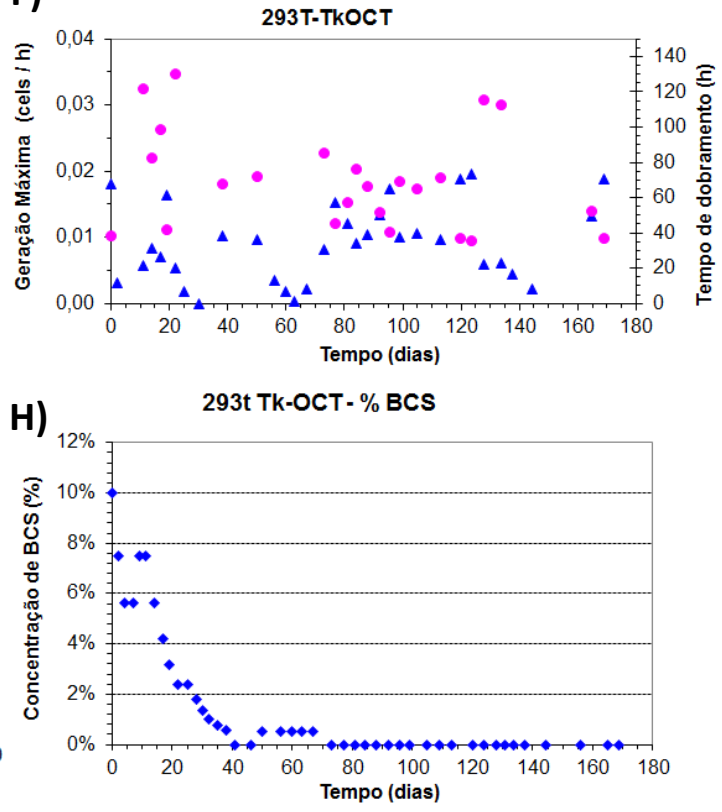

Figura 46: Adaptação das linhagens produtoras 293t e $\mathrm{CHO}$ aos meio de cultura CDM-CHO.

As células foram repicadas a cada 2-3 dias e verificadas quanto sua viabilidade (A) e (E) perfil proliferação celular, $(\mathbf{B})$ e (F) tempo de dobramento e de geração por hora, (C) e (G) viabilidade e (D) e (H) concentração de BCS. Quando houve diminuição abrupta da proliferação manteve-se a concentração de BCS ou ela foi até mesmo aumentada para o passo anterior, para assegurar a adaptação com perda mínima de células. 
É bastante evidente nos dois exemplos apresentados que no início da cultura há uma progressiva diminuição da taxa de proliferação. Na sequência, observa-se um período de cerca de 25 dias no qual praticamente não houve proliferação da população como um todo, apenas de alguns exemplares da população que têm a capacidade de proliferar nessas novas condições. Finalmente essa população atinge uma proporção mais elevada e é possível se obter uma alta concentração de células novamente. Em geral, ao invés dos 40-60 dias, levou cerca de 80-90 dias para que as células passassem a apresentar esse comportamento. Esse é um processo estocástico, trabalhoso e depende muito da sorte. Há relatos de tipos celulares que simplesmente não são possíveis de serem adaptados. Nesse trabalho, nem todas as produtoras

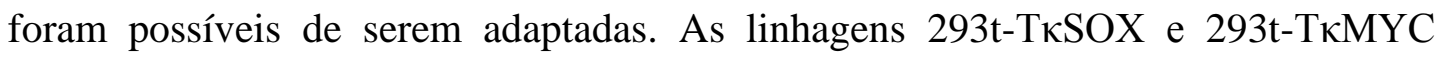
sucumbiram no processo.

Outra preocupação durante o processo foi verificar se estava havendo qualquer tipo de desligamento dos genes. E a situação não era das mais favoráveis ao se observar a porcentagem de células $\mathrm{GFP}^{+}$da população de $293 \mathrm{t}$ que foi adaptada (Figura 47A). Assim que as linhagens passaram a apresentar um perfil de proliferação mais estável feita a verificação da quantidade de proteínas que as células adaptadas estavam produzindo em condições padronizadas $\left(1 \times 10^{6}\right.$ células $/ \mathrm{mL}$, após 24h), de 2 a 4 produções independentes (Figura 47B). 
A)
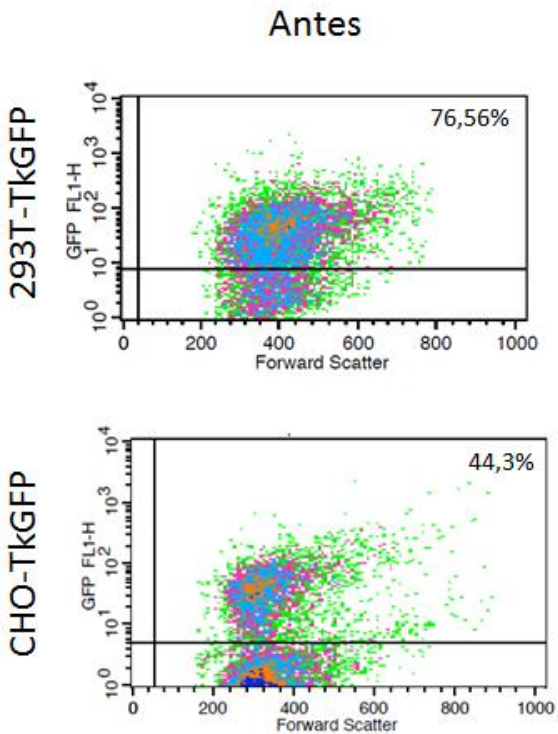

Pós adaptação
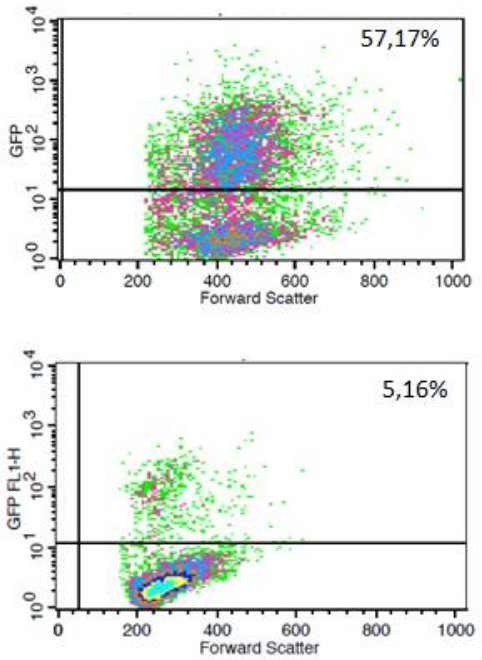

B)

\begin{tabular}{cccccc}
\hline & Condição & Tk-OCT & Tk-SOX & Tk-KLF & Tk-MYC \\
\multirow{2}{*}{$293 \mathrm{St}$} & Sem concentrar & $\tilde{N}$ detectado Ñ disponível & $260,7 \pm 58,5$ & $\tilde{N}$ disponível \\
& Concentrado & $\tilde{N}$ detectado Ñ disponível & $\tilde{N}$ detectado & Ñ disponível \\
\hline \multirow{2}{*}{ CHO } & Sem concentrar & $\tilde{N}$ detectado Ñ detectado & $57,20 \pm 13$ & $34,81 \pm 3,37$ \\
& & & & \\
& Concentrado & $34,78 \pm 4,58 \tilde{N}$ detectado & $178,77 \pm 126$ & $2023 \pm 280$ \\
\hline
\end{tabular}

Figura 47: Silenciamento gênico das linhagens produtoras 293t e CHO adaptadas ao cultivo em CDM-CHO.

(A) Density plots das células 293t e CHO produtoras de TATк-GFP antes e após a adaptação. (B) Quantidade de proteínas detectável no meio de cultura condicionado das células produtoras de TATк-fatores adaptadas. Valores em ng/mL.

Infelizmente, o efeito que se observa na diminuição das células TATк-GFP ${ }^{+}$ também se extende às células produtoras de fator. Elas passaram a produzir uma quantidade muito menor de proteínas do que o observado antes do início desse processo de adaptação. Para enfrentar esse problema foram pensadas três soluções possíveis: (1) reiniciar o processo de adaptação a partir de um número grande de clones independentes para cada tipo celular e torcer para que algum deles mantenha o 
perfil de produção após a adaptação ou (2) tentar isolar clones que tivessem maior capacidade de produção dentre as linhagens já adaptadas. Para essa segunda opção é possível realizar isso de duas maneira distintas, seja por varredura na população, após diluição limitante a 1 célula por poço ou transduzir sistemas repórteres lentivirais nessas células já adaptadas para que fosse possível selecionar as células que ainda mantém a produção de TATא-fatores usando citometria de fluxo. Atualmente o único sistema repórter disponível em lentivírus é para a proteína OCT, portanto as três possibilidades estão sendo tentadas. Espera-se que num curto período de tempo, populações que produzam quantidades expressivas de proteínas sejam selecionadas.

Uma maneira alternativa de produzir proteínas recombinantes em alta concentração é por meio da transfecção transiente dos plasmídeos. E essa abordagem também foi executada.

\subsubsection{Produção de proteínas recombinantes em células animais usando transfecção transiente}

De maneira análoga ao que é feito com os retrovírus, os plasmídeos pSecTag contendo os fatores de transcrição ou a proteína TATк-GFP foram transfectados de maneira transiente nas células 293t, que apresentou os maiores índices de secreção de proteína. Espera-se que haja produção de proteínas por pelo menos uma semana nessas condições, de maneira semelhante ao que foi apresentado com os lentivírus (Figura 17C). Foram realizados três lotes de experimento, com a transfecção na presença de FBS qualificado (Gibco, número de catálogo 16141-079) para cultivo de células ES sendo seguida da troca, sem lavagens com PBS, para o meio DMEM ou CDM-CHO, ambos não suplementados com BCS. A utilização desse FBS especial a 
princípio deve mitigar o possível efeito na diferenciação celular das células iPS (que tinha sido observado anteriormente com BCS). Na sequência, o meio de cultura foi trocado a cada $24 \mathrm{~h}$ e o experimento abortado quando um número grande de células tivesse desprendido da placa (Figura 48). Em paralelo para comparação, células

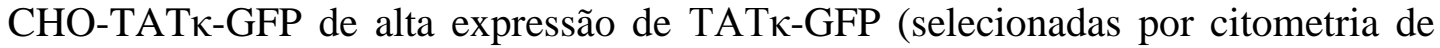
fluxo) foram usadas para produzir TATא-GFP nas mesmas condições da placa que sofreu transfecção. Isso foi realizado, pois as células CHO, diferentemente das 293t, não soltam da placa com facilidade, mesmo na ausência de FBS.

A)
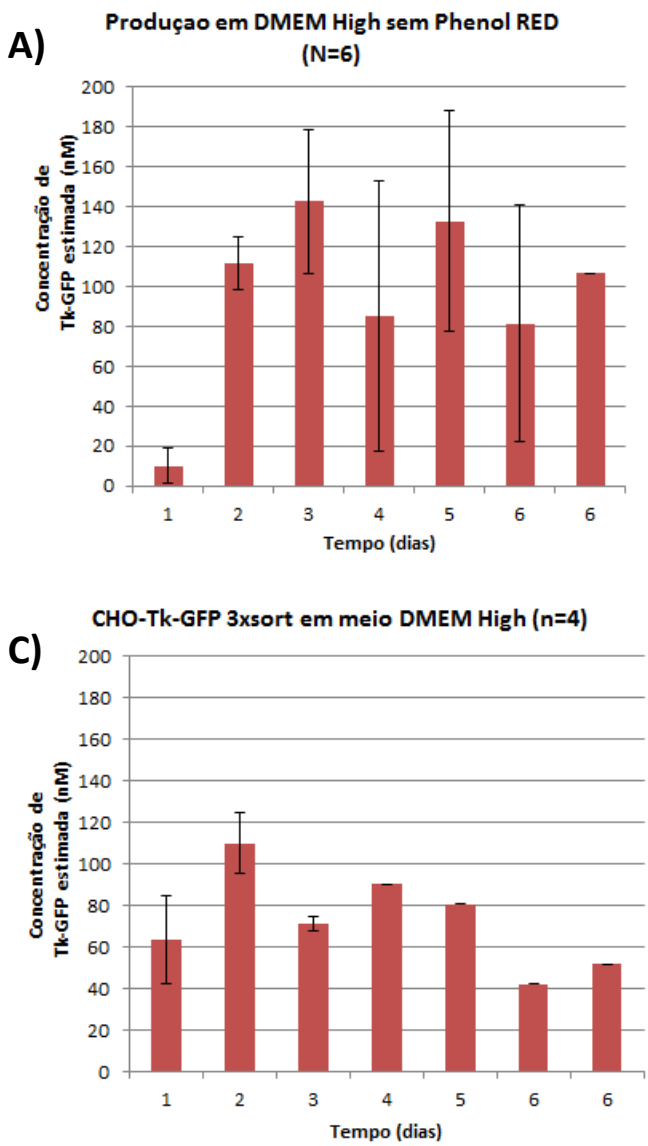
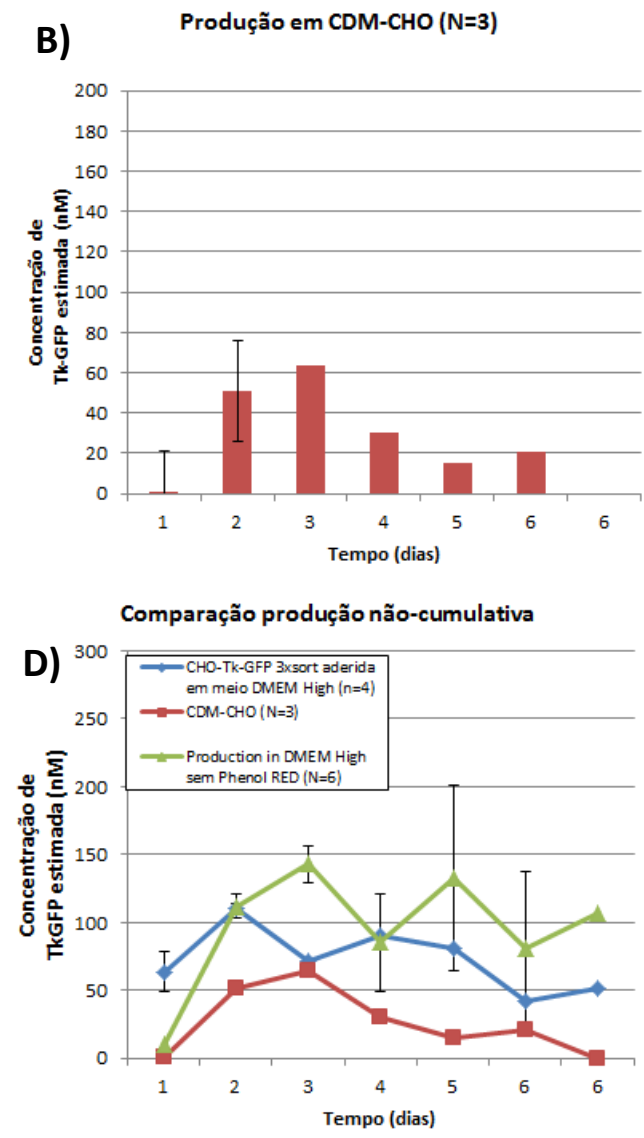

Figura 48: Perfil de produção de TATк-GFP por até sete dias por células 293t transfectadas com lipofectamina de maneira transiente

A produção de TATк-GFP foi feita em meio (A) DMEM sem phenol red ou (B) meio CDM-CHO. (C) Além disso, foi realizada a coleta de meio condicionado de células CHO-TATк-GFP separadas por citometria de fluxo e mantidas nas mesmas condições das células transfectadas (meio DMEM). Em (D) os mesmos dados são plotados agrupados, para facilitar a comparação. 
A presença dos fatores de transcrição no meio de cultura foi verificado por

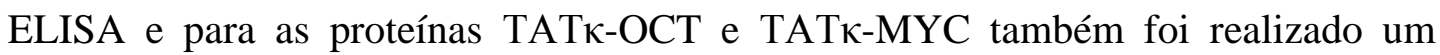
Western Blotting utilizando-se um conjunto de anticorpos diferentes dos quais foi utilizado no ELISA (Figura 49). O mesmo padrão de pouca expressão no dia 2, seguindo de uma alta expressão nos dias subsequentes foi observado em ambas as abordagens.

A)
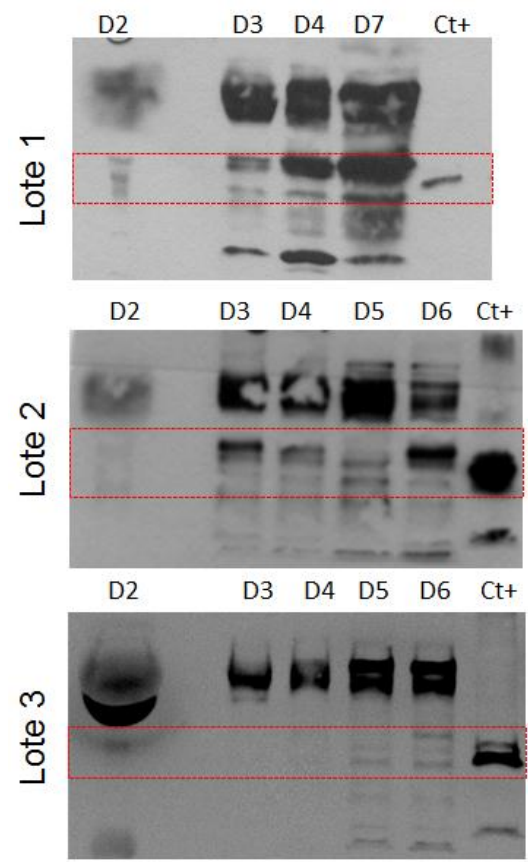

B) $\quad$ TkMYC
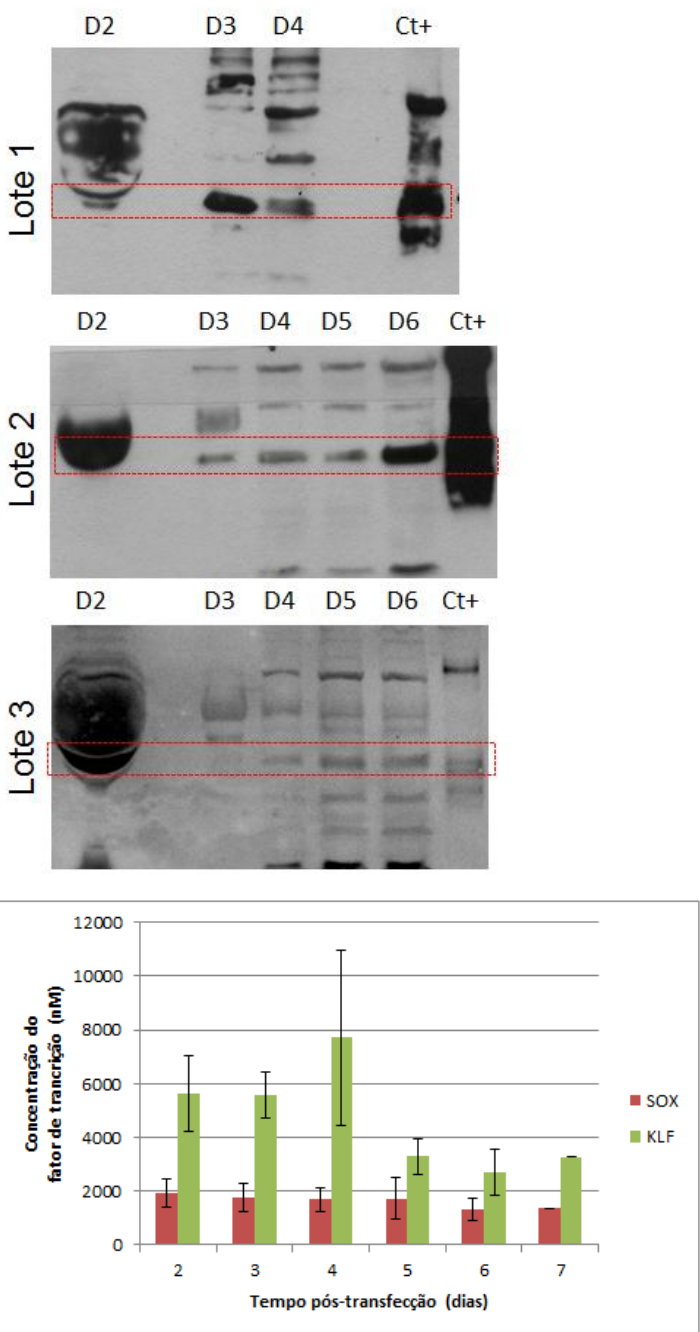

Figura 49: Analise da expressão de proteína por Western Blotting de (A) TATкOCT e (B) TATк-MYC no meio de cultura nos sete dias de produção das células $293 t$ transfectadas de maneira transiente. Chama atenção também a extensa marcação inespecífica dos anticorpos. 
Chama bastante a atenção a diferença de intensidade entre os níveis detectáveis

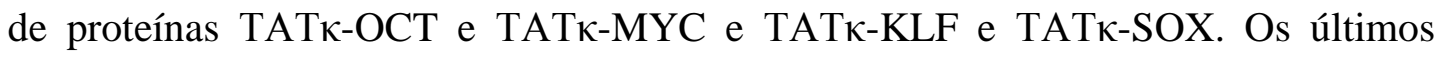
estão em torno de 100x mais concentrados no meio de cultura. Além disso, observase uma expressão relativamente mais baixa de OCT e MYC no dia 2 de coleta.

Uma possível explicação é a presença de proteínas séricas (particularmente BSA, que possui aproximadamente $60 \mathrm{KDa}$ ) em maior quantidade nos primeiros dias, que está inclusive sendo marcada inespecificamente bastante visivelmente no dia 2 de coleta. De maneira a verificar o nível de contaminação por BCS, as diferentes amostras foram analisadas por gel de acrilamida com coloração Coomassie Blue (Figura 50). Como pode ser observado, na medida em que o meio de cultura é trocado ao longo dos dias vai havendo uma gradativa diminuição do BCS contaminante e a produção de TATא-fatores se mantém relativamente constante. Além disso, realizando-se a dosagem de proteína total usando o método de Bradford dos meios de cultura e utilizando-se contomitantemente os dados de ELISA é possível estimar a concentração de FBS final que o meio de cultura nas quais as células serão tratadas fica. Pode se observar que exceto o meio do dia 2 de coleta, a concentração de FBS gira em torno de $0,5 \%$. 
A)

TKOCT
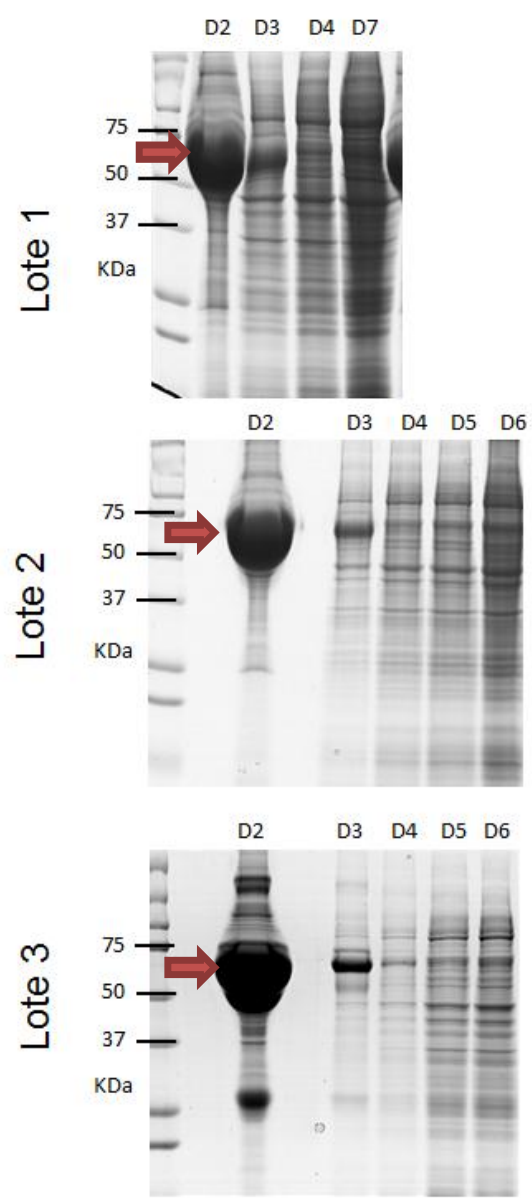

B)

TkMYC
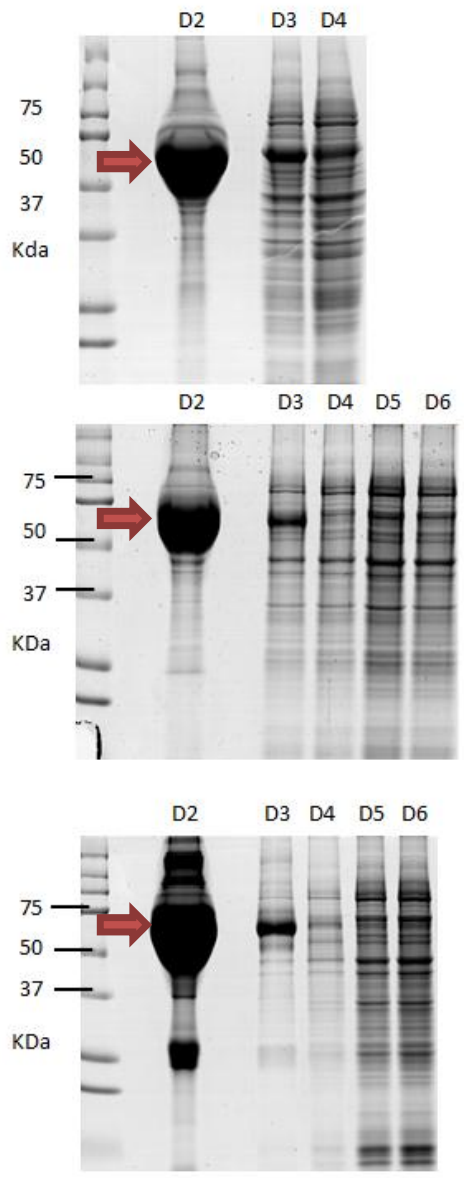

C)

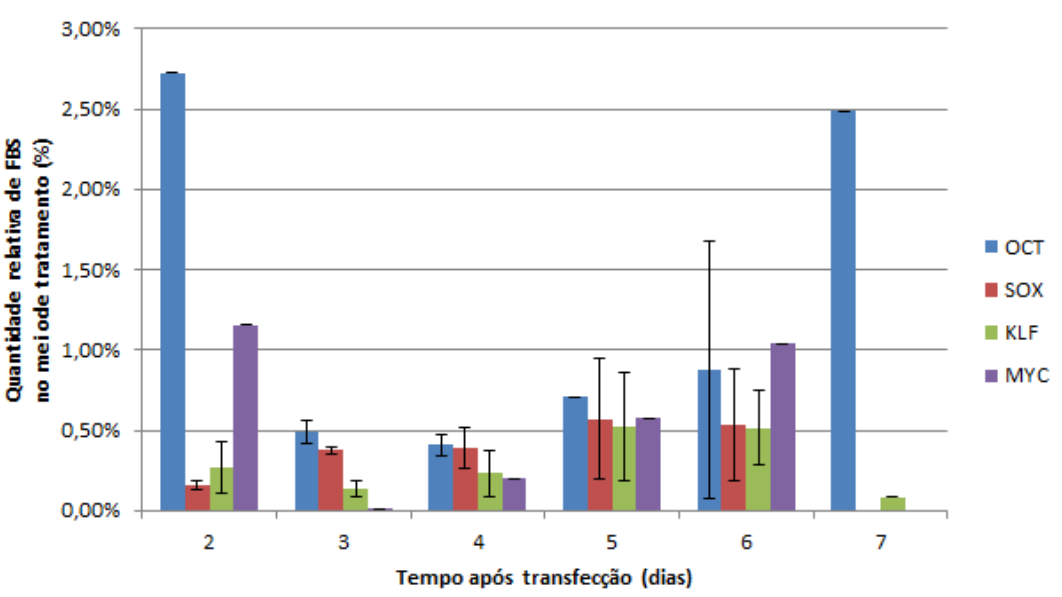

Figura 50: Analise da presença de proteínas contaminantes derivadas do BCS no meio de cultura condicionado.

Nos sete dias de produção das células 293t transfectadas com (A) TATк-OCT e (B) TATк-MYC de maneira transiente. A seta vermelha indica o BSA. (C) Quantidade relativa de FBS em meio de cultura para tratamento das células. 
As proteínas produzidas dos 3 diferentes lotes foram armazenadas em freezer $80^{\circ} \mathrm{C}$ para serem utilizadas para um último experimento de tentativa de reprogramação de células MEF. Planejou-se complementar com proteína a expressão dos retrovírus respectivos, conforme a abordagem anterior (intervalos de troca de meio de 3 dias, com meio contendo 0,5mM Ácido Valpróico e também 5mM Cloreto de Lítio ${ }^{80}$, sempre em atmosfera contendo $3 \%$ de oxigênio). Assim, calculou-se para utilizar 100nM das proteínas SOX e KLF e 5nM das proteínas OCT e MYC, quando com os vírus estivessem presentes. E a titulo de teste, foi realizada a combinação das quatro proteínas a $5 \mathrm{nM}$ em um poço à parte. Não foi utilizada uma quantidade maior de OCT $^{79}$ devido ao fato da produção de OCT não ter alcançado níveis elevados. Além disso, tomou-se o cuidado de utilizar os tubos com maior quantidade de BCS nos primeiros dias de tratamento.

Infelizmente, mesmo com essa ultima estratégia determinística, ainda assim não foi possível obter a reprogramação das células no acompanhamento por até 21 dias após a transdução e início dos tratamentos (Figura 51).
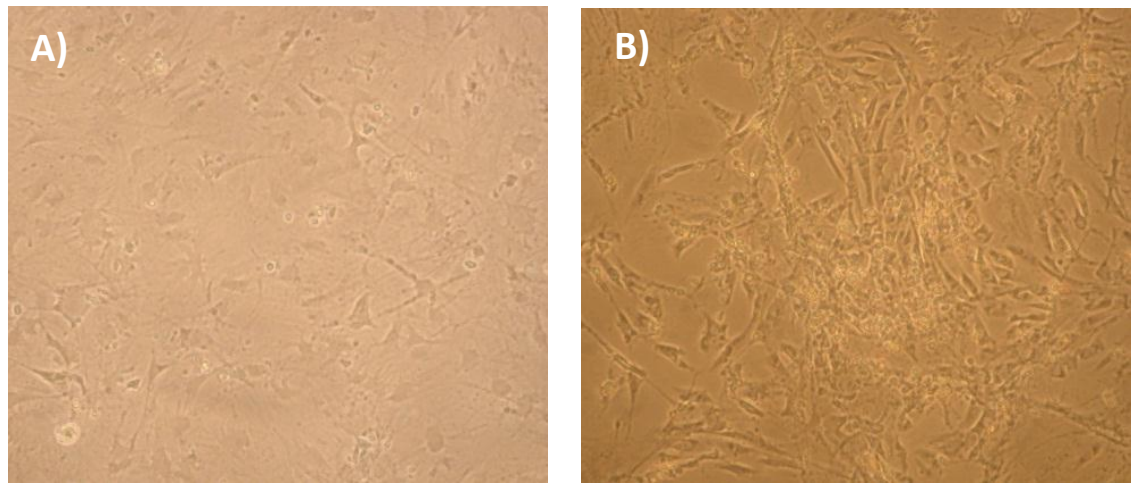

Figura 51: Figura representativa das células MEF 12 dias após o inicio do tratamento com proteínas. (A) Ctrl neg e (B) células infectadas com retrovírus pMX para expressar OSM e tratadas com a proteína recombinante KLF. Após 30 dias nenhuma colônia foi observada (Aumento de 100x). 
5. Discussão 
Nesta tese foi descrito o desenvolvimento de um sistema de plasmídeos que pode ser útil para gerar células iPS à base de proteínas, sem manipulação genética. Começou-se pelo estabelecimento de um bom método fluorimétrico para a verificação quantitativa de GFP em meio sobrenadante, validou-se vários métodos para a identificação de células pluripotentes e foram testadas diferentes estratégias para a entrega de fatores de transcrição in vitro. Em seguida, foram testados os PTDs TAT e TAT $\kappa$, sendo a último mais eficientemente produzido e secretado por sua resistência à ação de proteases citoplasmáticas. Finalmente, foi selecionada a melhor linhagem celular para produzir TATк-GFP e os quatro fatores de transcrição nuclear fundidos à TATк, que seria necessário para gerar células iPS. Além de desenvolver uma abordagem livre de vírus, o desafio atual é obter iPS sem qualquer manipulação genética - de forma a evitar a introdução de DNA exógeno na célula (com o efeito imprevisível na ativação de gene) - e a seleção de colônias de células iPS livres da integração do plasmídeo no genoma. Outro aspecto interessante da abordagem proposta é a possibilidade de se verificar se diferentes quantidades dos fatores promovem uma reprogramação mais eficiente.

Em 2009, Zhou, e colaboradores ${ }^{110}$ descreveram a geração de células iPS sem vetores de DNA bacteriano, utilizando proteínas recombinantes sintéticas produzidas em bactérias. OSKM foram fundidos a uma tag PTD de poli-arginina e células MEF foram tratadas com $8 \mu \mathrm{g} / \mathrm{mL}$ de proteínas em quatro ciclos. Em cada ciclo, as células foram tratadas por $24 \mathrm{~h}$ em meio suplementado com 1mM VPA e as proteínas, seguido de uma troca para o meio sem as proteínas de reprogramação e VPA por mais 36 horas, antes do próximo ciclo do tratamento. Apesar de obter sucesso, (três colônias verdadeiras), a baixa eficiência de reprogramação é bastante evidente, bem 
como o atraso no tempo (foi necessário aguardar 56 dias em vez de 20-30, como acontece com os vírus). Esse trabalho utilizou um PTD de poli-arginina, em vez de TAT, que já foi demonstrado ser menos eficientes para a transdução de células ${ }^{122}$. Além disso, muitas proteínas requerem modificações pós-traducionais para a atividade biológica completa que poderia explicar, pelo menos em parte, a sua baixa eficiência. A glicosilação é a principal modificação pós-traducional estudada. Ela requer uma extensa série de etapas de processamento realizado no retículo endoplasmático e complexo de Golgi. Células procarióticas, no entanto, não têm qualquer via metabólica para a glicosilação, portanto, as proteínas produzidas não são glicosiladas. Além disso, leveduras, fungos filamentosos, células de insetos e plantas são capazes de promover a glicosilação, mas produzem uma estrutura de glicano significativamente diferentes daqueles encontrados nas glicoproteínas de mamíferos ${ }^{123}$. Fatores nucleares também podem ser glicosilados ${ }^{124,125}$, porém para os quatro fatores de reprogramação nuclear esse fenômeno ainda não foram ainda extensivamente estudados. Usando métodos de previsão por bioinformática nas sequências das proteínas geradas nesse trabalho, pode-se observar que existem muitos resíduos potencialmente susceptíveis a importantes modificações póstraducionais como N- e O-glicosilação ${ }^{126-128}$, glicação ou sítios de manosilação (dados não mostrados). As modificação pós-traducionais podem afetar a atividade da proteína nuclear de forma significativa. Recentemente foi mostrado que a PARP1, que é responsável pela ligação covalente de poli(ADP-ribose) a si próprio e outros receptores de proteína nuclear, interage com Sox 2 diretamente e modifica Sox 2 por poli(ADP) ribosilação, que pode ser um passo necessário para dissociação do Sox2 excessivo do enhancer FGF4 ${ }^{129}$. 
Outro fator que deve ser observado é a possibilidade de interferência do PTD na atividade dos fatores nucleares. Essa foi uma preocupação desde o início desse projeto, motivo pelo qual não foi mantida a cauda HA na porção C-terminal (que facilitaria em muito o processo de quantificação por ELISA). Essa questão foi abordada por Konno e colaboradores ${ }^{130}$ numa recente short-communication. Eles investigaram a hipótese de que o PTD poli-arginina-11R, com onze argininas fundidas na posição N-terminal, pode interferir na atividade de SOX2 e Oct3/4. Para avaliação foi utilizado um modelo de células ES onde a expressão dos genes OCT e SOX é abolida e ela pode ter sua função mantida ao se tratar as células com os fatores nucleares fundidos ao PTD, mas com menor eficiência do que o gene original. Quando essas células são tratadas para co-expressarem uma protease sitioespecífica (nomeado TEV, derivado do vírus do tabaco) que capaz de dissociar o PTD da proteína de fusão (11R-OCT e 11R-SOX), a atividade de fatores de transcrição é aumentada. Ainda neste contexto, Tang et al ${ }^{131}$ investigou se a posição do PTD, quer seja $\mathrm{N}$ - ou $\mathrm{C}$-terminal, interfere na capacidade do TAT-KLF ou Penetrating-KLF recombinante (Penetrating é outro tipo de PTD) de promover a reprogramação. Tratando células previamente infectadas com retrovírus para expressar Oct4, Sox2 e c-Myc com "TAT-KLF4" ou "Penetrating-KLF" recombinante eles demonstraram que ambos as proteínas apresentam que o PTD na porção C-terminal são capazes de induzir a geração de iPS (utilizando proteína em nível nanomolar após 2 a 4 semanas). No entanto, quando o PTD está localizado na porção N-terminal (semelhante a construção do presente trabalho) não é observado nenhuma atividade de reprogramação. Com base no rastreamento de fluorescência ao microscópio, eles demonstram que não há localização nuclear da TAT-KLF quando 
o PTD está N-terminal (apenas citoplasmática, perinuclear) possivelmente por “problemas no enovelamento da proteína ou na apreensão endossomal da maioria das proteínas transduzidas devido ao tráfico intracelular inadequado". Esses autores também realizaram uma otimização de protocolo de tratamento (variando de dosagem de proteína, intervalo de transdução, duração do tratamento por ciclo, e o número de ciclos de transdução) e demonstraram que quatro ciclos de exposição de TAT-KLF4 recombinante na dose de 50-65nM, com um intervalo de transdução de $72 \mathrm{~h}$ é o método mais eficiente para a indução de iPS. Finalmente, eles também relatam o aparecimento de colônias parecidas com iPS, mas que não são verdadeira (cerca de 12-27\%), de maneira semelhante ao que foi observado nessa tese. Em conjunto, esses resultados são muito encorajadores e dão a expectativa de que é possível ter sucesso na reprogramação de células usando proteínas recombinantes provenientes de mamíferos, exceto talvez pela KLF, se o PTD TATא estiver posicionado na porção N-terminal. Extratos de proteínas das células 293t expressando a quatro fatores nucleares fundido a tag poli-arginina e myc também foram usado para reprogramar as células de fibroblastos humanos (123). Ambos os tags PTD e myc foram posicionados na posição C-terminal e reprogramação foi obtida após seis ciclos de tratamento de proteína por 16 horas. Além disso, Kim e colaboradores ${ }^{132}$ conseguiram sucesso na reprogramação usando apenas uma única transferência de $20-35 \mathrm{mg} / \mathrm{mL}$ de proteínas derivadas de células ES utilizando-se de permeabilização reversível mediada por estreptolisina-O em fibroblastos de camundongos, sem forçar expressão ectópica nas células.

É importante notar que, em comum, todos os procedimentos acima mencionados tiveram eficiência reprogramação baixa em comparação com 
protocolos baseados em retrovírus (10 vezes abaixo, o que corresponde a $\sim 0,001 \%$ das células de partida do experimento). Acredita-se que as proteínas recombinantes sejam re-enoveladas nas células-alvo, por meio de chaperonas endógenas ${ }^{71}$. O tráfico intracelular inadequado e problemas na liberação endossomal ${ }^{133}$ de fato podem representar um fator limitante para a transdução de proteína recombinante ${ }^{134}$. Uma vez que a destruição dos endossomos pode aumentar a liberação das proteínas de fusão para o citosol e núcleo, existem abordagens que interferem na integridade do endossomo utilizando cloroquina ${ }^{133}$. Essa poderia ser utilizada para tentar melhorar a eficiência da reprogramação nuclear nos sistemas baseados em proteínas.

Algumas outras novas alternativas técnicas para atingir a reprogramação nuclear de maneira mais segura foram publicadas nos últimos 3 anos. Células iPS foram gerados a partir de fibroblastos humanos utilizando adenovírus ${ }^{78,}{ }^{135} \mathrm{e}$ Sensaivirus 136, 137 sem integração no genoma, plasmídeos não-integrativos epissomais ${ }^{138}$, e plasmídeos de expressão múltipla integrativa relacionados ou não ao transposon piggyBac ${ }^{92,98,139-141}$. Além disso, é possível promover reprogramação de MEFs usando moléculas BIX-01.294 para substituir o fator SOX2, já na ausência de c-MYC ${ }^{142}$ ou até mesmo por transfecção dos quatro fatores na forma de mRNA modificado para não elicitar a resposta imune celular ${ }^{143-145}$ Figura 52). Essas abordagens, diferentemente das que utilizam vírus não são de amplo uso e continuam restritas aos laboratórios de origem, seja pela exclusividade de seus plasmídeos para uso comercial (por exemplo Transposagen Biopharmaceuticals, Inc. que detêm direitos sobre plasmídeos de tecnologia piggyBac), ou pela complexidade de execução na transfecção dos RNAm ${ }^{144}$. 


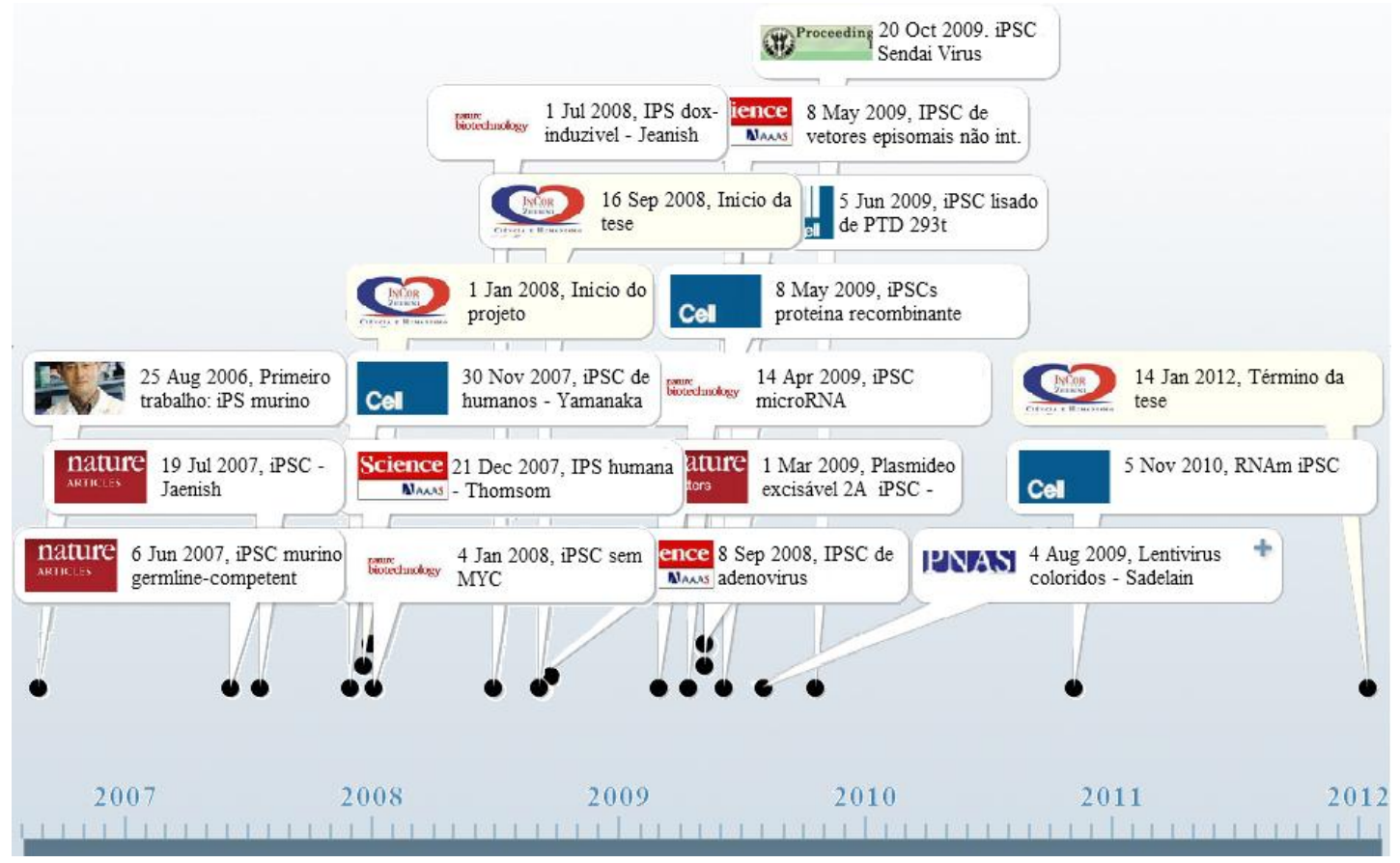

Figura 52: Visão geral dos principais trabalhos publicados sobre métodos para reprogramação celular durante o período do projeto.

Além disso, já foi possível se realizar reprogramação de células mesenquimais de medula óssea ${ }^{146}$ e de tecido adiposo ${ }^{109}$ sendo inclusive reportando que é mais freqüente o aparecimento de colônias iPS do que quando é utilizado MEFs nesse processo.

Em conclusão, exceto para as abordagens que usam mRNA e proteínas, a maioria dos estudos ainda usa de alguma forma de manipulação genética que confere limitações para aplicação adicional dessas células. Assim, o desenvolvimento de alternativas mais seguras é altamente desejável ${ }^{96}$. Ainda que os transgenes possam ser removidos pela expressão transiente de LOXp, as sequências residuais e possíveis alterações cromossômicas podem ainda resultar em alterações prejudiciais que põem em risco possíveis aplicações clínicas dessas células. Mais recentemente, a abordagem utilizando um RNAm modificado parece bastante promissora, uma vez 
que não induz resposta imune celular inata e tem sido demonstrando a estratégia de maior eficiência (até $4 \%$ de células de entrada) até agora ${ }^{144}$.

Os dados apresentados nessa tese mostram que o método de co-cultivo por transwell, que inicialmente previsto para ser o mais promissor, está associada com baixa eficiência de entrega de proteínas. Para superar essa limitação, foi realizada a concentração dos fatores de transcrição por meio de coluna Amicon (10 kDa), evitando assim o contato das células alvo com o meio excessivamente consumido. Entretanto, o soro fetal que também é concentrado por essa abordagem, impõe dificuldades à reprogramação, por ser um estimulo à diferenciação. Como exemplo disso, observa-se que a eficiência na geração iPS é maior quando usando KSR, em vez de FBS no processo. Contudo, ela fica menor em concentração superiores a $20 \%$ 121. A fim de abordar estas limitações, as células produtoras foram adaptadas ao cultivo em meio quimicamente definido, sem BCS, antes da concentração em colunas. Infelizmente, ao longo do processo de adaptação as células perderam a capacidade de produzir em quantidades razoáveis os fatores de transcrição. Essa limitação foi contornada realizando-se ensaios de determinação de clones que não apresentam esse fenótipo e esses experimentos continuam em andamento em colaboração com o IPT. Numa última tentitiva de curto prazo, foi realizada um produção de fatores de transcrição utilizando a transfecção transientes em células 293t. Dessa maneira conseguiu-se uma quantidade grande de material com um nível de contaminação por FBS relativamente pequeno. Esse material foi utilizado para uma tentativa de reprogramação, contudo não foi obtido sucesso.

Embora não tenha sido possível realizar a reprogramação nuclear de células nesse trabalho, provavelmente devido a presença de soro fetal e da (relativa) baixa 
quantidade de proteínas produzidas, acredita-se que a eficiência da abordagem proposta pode ser melhorada ainda mais. Em publicações mais recentes ${ }^{110,147}$ tem sido demonstrado que pode ser necessário aumentar o tempo de exposição por períodos mais longos para obter colónias consistentes. Talvez em nosso sistema também seja necessário aumentar o tempo de tratamento para alcançar o sucesso na reprogramação nuclear. 
6. Conclusões 


\subsection{Conclusões Sumarizadas}

Nesse trabalho verificou-se que não é possível, nas condições testadas, promover a reprogramação de fibroblastos e/ou células mesenquimais de tecido adiposo de camundongos (mASC) e humanos (hASC) em células iPS utilizando os fatores de transcrição OCT3/4, SOX2, KLF4 e c-MYC fusionados ao peptídeo carreador TAT.

Além disso, nesse trabalho:

a) Foram estabelecidas as células iPS murinas e humanas no laboratório (utilizando vírus) e elas serviram como modelo de comparação para reprogramação utilizando proteínas fusionadas;

b) Foram gerados os plasmídeos contendo as sequencias dos fatores de transcrição e GFP fusionados a TAT- ou TATא-, importante para se testar a hipótese de trabalho.

c) Foram padronizados os métodos de detecção de proteína no meio de cultura fluorescente (para GFP) e de ELISA (para os fatores de transcrição).

d) Foi estabelecido um método de entrega dos fatores de transcrição mais eficiente do que utilizar placas transwell. 


\subsection{Conclusão Final}

Tomados em conjunto, os dados obtidos neste estudo fornecem evidências de que o processo de reprogramação de fibroblastos requer uma quantidade de proteínas e a manutenção de condições de cultura bastante específicas, o que torna inviável a reprogramação por co-cultivo com células produtoras de fatores. Por outro lado, essas células produtoras de fatores podem ser utilizadas como modelos para produção de proteínas recombinantes, contendo modificações pos-traducionais. Essas proteínas podem ser futuramente testadas para a possibilidade de reprogramação nuclear. 
7. Perspectivas 
Células iPS geradas com tecnologias à base de proteínas eucarióticas, potencialmente, podem oferecer um método mais seguro para gerar células-tronco específicas do paciente, sem haver destruição de embriões ex-útero. A transdução de OSKM também foi demonstrada como possível de ser empregada para a reprogramação nuclear direta de fibroblastos em cardiomiócitos, (142) quando utilizada condições de cultura específicas. O sistema apresentado poderá eventualmente eliminar a manipulação do genoma e da transfecção e, possivelmente, pode resultar em células iPS mais adequadas para a modelagem de eficiência da fármacos de forma paciente-específica, a modelagem de doenças e uma futura translação para a clínica médica. Uma solução para o problema quantitativo e de contaminação de proteínas está sendo desenvolvida em colaboração com o IPT. 
8. Anexos 
Anexo A. Cópia do parecer de aprovação do projeto no Comitê de Ética para Análise de projetos de Pesquisa-CAPPesq.

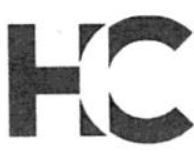

\section{APROVAÇĀO}

A Comissão de Ética para Análise de Projetos de Pesquisa CAPPesa da Diretoria Clínica do Hospital das Clínicas e da Faculdade de Medicina da Universidade de São Paulo, em sessão de 03/12/2008, APROVOU ○ Protocolo de Pesquisa n 0949/08, intitulado: "REPROGRAMAÇĀO DIRIGIDA DE CÉlULAS MESENQUIMAIS DE TECIDO ADIPOSO EM CÉlULAS-TRONCO PLURIPOTENTES E CARDIOMIÓCITOS" apresentado pela COMISSÂO CIENTíFICA DO INCOR, inclusive o Termo de Consentimento Livre e Esclarecido.

Cabe ao pesquisador elaborar e apresentar à CAPPesq, os relatórios parciais e final sobre a pesquisa (Resolução do Conselho Nacional de Saúde n 196, de 10/10/1996, inciso IX.2, letra "c").

Pesquisador (a) Responsável: Prof. Dr. José Eduardo Krieger

Pesquisador (a) Executante: Chester Bittencourt Sacramento; Vinícius Bassaneze

CAPPesq, 04 de Dezembro de 2008

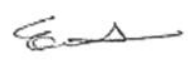

Prof. Dr. Eduardo Massad

Presidente da Comissāo de Ética para Análise de Projetos COMISSÄO CIENTIFICA de Pesquisa

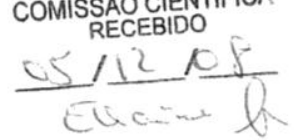

Comissāo de Ética para Análise de Projetos de Pesquisa do HCFMUSP e da FMUSP Diretoria Clínica do Hospital das Clínicas da Faculdade de Medicina da Universidade de Săo Paulo Rua Ovidio Pires de Campos, 225, $5^{\circ}$ andar - CEP 05403010 - São Paulo - SP Fone: 01130696442 Fax: 01130696492 e-mail: cannesnßhhr.net usn hr / secretariacadoesa2@hcnet.usp.br 
Anexo B. Cópia do parecer de aprovação pelo CAPPesq da inclusão de subprojeto no processo 0949/9.

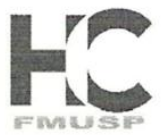

Hospital das Clínicas da FMUSP

Comissão de Ética para Análise de Projetos de Pesquisa

CAPPesq

N' Protocolo: 0949/08

Título: "Reprogramação Dirigida De Células Mesenquimais De Tecido Adiposo Em Células-Tronco Pluripotentes E Cardiomiócitos"

Pesquisador Responsável: José Eduardo Krieger

Pesquisador Executante: Chester Bittencourt Sacramento e Vinícius Bassaneze

Finalidade Acadêmica: Doutorado

Departamento: Comissão Científica do InCor

A Comissão de Ética para Análise de Projetos de Pesquisa CAPPesa da Diretoria Clínica do Hospital das Clínicas da Faculdade de Medicina da Universidade de São Paulo, APROVOU / TOMOU CIÊNCIA na sessão datada de 19/10/2011, do(s) documento(s) abaixo mencionado(s):

- Carta datada de 17/08/11:

- Relatório parcial.

- Inclusão de Vinicius Bassaneze para realização do subprojeto "Reprogramação de células mesenquimais de tecido adiposo em célulastronco pluripotentes por meio de proteína de fusão TAT" como tese de doutorado.

- Inclusão de Chester Bittencourt Sacramento para realização do subprojeto "Reprogramação de fibroblastos em células-tronco pluripotentes e diferenciação destas em cardiomiocitos por meio da expressão de fatores de transcrição cardíacos" como tese de doutorado.

Rua Dr. Ovidio Pires de Campos, 225 - Prédio da Administração - $5^{\circ}$ andar - CEP 05403-010 - São Paulo - SP. Fone: 5511 3069-6442 ramais 16, 17, 18 e 20 - e-mail: cappesq@hcnet.usp.br 


\section{Referências Bibliográficas}


1. Okrainec K, Banerjee DK, Eisenberg MJ. Coronary artery disease in the developing world. Am Heart J. 2004;148(1):7-15.

2. Farias N, Souza JMP, Laurenti R, Alencar SM. Mortalidade Cardiovascular por Sexo e Faixa Etária em São Paulo, Brasil: 1996 a 1998 e 2003 a 2005. Arq Bras Cardiol. 2009;93(5):498-505.

3. Loehr LR, Rosamond WD, Chang PP, Folsom AR, Chambless LE. Heart failure incidence and survival (from the Atherosclerosis Risk in Communities study). Am J Cardiol. 2008;101(7):1016-22.

4. Urbanek K, Cesselli D, Rota M, Nascimbene A, De Angelis A, Hosoda T, et al. Stem cell niches in the adult mouse heart. Proc Natl Acad Sci U S A. 2006;103(24):9226-31.

5. Quaini F, Urbanek K, Beltrami AP, Finato N, Beltrami CA, Nadal-Ginard B, et al. Chimerism of the transplanted heart. N Engl J Med. 2002;346(1):5-15.

6. Hsieh PC, Segers VF, Davis ME, MacGillivray C, Gannon J, Molkentin JD, et al. Evidence from a genetic fate-mapping study that stem cells refresh adult mammalian cardiomyocytes after injury. Nat Med. 2007;13(8):970-4.

7. Bergmann O, Bhardwaj RD, Bernard S, Zdunek S, Barnabe-Heider F, Walsh $\mathrm{S}$, et al. Evidence for cardiomyocyte renewal in humans. Science. 2009;324(5923):98-102.

8. Gersh BJ, Simari RD, Behfar A, Terzic CM, Terzic A. Cardiac cell repair therapy: a clinical perspective. Mayo Clin Proc. 2009;84(10):876-92.

9. Gyurkocza B, Rezvani A, Storb RF. Allogeneic hematopoietic cell transplantation: the state of the art. Expert Rev Hematol. 2010;3(3):285-99. 
10. Li RK, Mickle DA, Weisel RD, Zhang J, Mohabeer MK. In vivo survival and function of transplanted rat cardiomyocytes. Circ Res. 1996;78(2):283-8.

11. Li RK, Jia ZQ, Weisel RD, Mickle DA, Zhang J, Mohabeer MK, et al. Cardiomyocyte transplantation improves heart function. Ann Thorac Surg. 1996;62(3):654-60; discussion 60-1.

12. Sakai T, Li RK, Weisel RD, Mickle DA, Jia ZQ, Tomita S, et al. Fetal cell transplantation: a comparison of three cell types. J Thorac Cardiovasc Surg. $1999 ; 118(4): 715-24$

13. Sakakibara Y, Tambara K, Lu F, Nishina T, Nagaya N, Nishimura K, et al. Cardiomyocyte transplantation does not reverse cardiac remodeling in rats with chronic myocardial infarction. Ann Thorac Surg. 2002;74(1):25-30.

14. Taylor DA, Atkins BZ, Hungspreugs $P$, Jones TR, Reedy MC, Hutcheson KA, et al. Regenerating functional myocardium: improved performance after skeletal myoblast transplantation. Nat Med. 1998;4(8):929-33.

15. Leobon B, Garcin I, Menasche P, Vilquin JT, Audinat E, Charpak S. Myoblasts transplanted into rat infarcted myocardium are functionally isolated from their host. Proc Natl Acad Sci U S A. 2003;100(13):7808-11.

16. Durrani S, Konoplyannikov M, Ashraf M, Haider KH. Skeletal myoblasts for cardiac repair. Regen Med. 2010;5(6):919-32.

17. Thomson JA, Itskovitz-Eldor J, Shapiro SS, Waknitz MA, Swiergiel JJ, Marshall VS, et al. Embryonic stem cell lines derived from human blastocysts. Science. 1998;282(5391):1145-7. 
18. Wen Y, Meng L, Xie J, Ouyang J. Direct autologous bone marrow-derived stem cell transplantation for ischemic heart disease: a meta-analysis. Expert Opin Biol Ther. 2011;11(5):559-67.

19. Strauer BE, Steinhoff G. 10 years of intracoronary and intramyocardial bone marrow stem cell therapy of the heart from the methodological origin to clinical practice. J Am Coll Cardiol. 2011;58(11):1095-104.

20. Danoviz ME, Bassaneze V, Nakamuta JS, Santos-Junior GR, Saint-Clair D, Bajgelman MC, et al. Adipose tissue-derived stem cells from humans and mice differ in proliferative capacity and genome stability in long-term cultures. Stem Cells Dev. 2010.

21. Abdel-Latif A, Bolli R, Tleyjeh IM, Montori VM, Perin EC, Hornung CA, et al. Adult bone marrow-derived cells for cardiac repair: a systematic review and metaanalysis. Arch Intern Med. 2007;167(10):989-97.

22. Mummery CL, Davis RP, Krieger JE. Challenges in using stem cells for cardiac repair. Sci Transl Med. 2010;2(27):27ps17.

23. Noiseux N, Gnecchi M, Lopez-llasaca M, Zhang L, Solomon SD, Deb A, et al. Mesenchymal stem cells overexpressing Akt dramatically repair infarcted myocardium and improve cardiac function despite infrequent cellular fusion or differentiation. Mol Ther. 2006;14(6):840-50.

24. Toma C, Pittenger MF, Cahill KS, Byrne BJ, Kessler PD. Human mesenchymal stem cells differentiate to a cardiomyocyte phenotype in the adult murine heart. Circulation. 2002;105(1):93-8. 
25. Orlic D, Kajstura J, Chimenti S, Jakoniuk I, Anderson SM, Li B, et al. Bone marrow cells regenerate infarcted myocardium. Nature. 2001;410(6829):701-5.

26. Di Nicola M, Carlo-Stella C, Magni M, Milanesi M, Longoni PD, Matteucci P, et al. Human bone marrow stromal cells suppress T-lymphocyte proliferation induced by cellular or nonspecific mitogenic stimuli. Blood. 2002;99(10):3838-43.

27. Tsuruda T, Kato J, Kitamura K, Kawamoto M, Kuwasako K, Imamura T, et al. An autocrine or a paracrine role of adrenomedullin in modulating cardiac fibroblast growth. Cardiovasc Res. 1999;43(4):958-67.

28. Nakamura T, Mizuno S, Matsumoto K, Sawa Y, Matsuda H, Nakamura T. Myocardial protection from ischemia/reperfusion injury by endogenous and exogenous HGF. J Clin Invest. 2000;106(12):1511-9.

29. Tang YL, Zhao Q, Zhang YC, Cheng L, Liu M, Shi J, et al. Autologous mesenchymal stem cell transplantation induce VEGF and neovascularization in ischemic myocardium. Regul Pept. 2004;117(1):3-10.

30. Wang M, Crisostomo PR, Herring C, Meldrum KK, Meldrum DR. Human progenitor cells from bone marrow or adipose tissue produce VEGF, HGF, and IGF-I in response to TNF by a p38 MAPK-dependent mechanism. Am J Physiol Regul Integr Comp Physiol. 2006;291(4):R880-4.

31. Gimble JM, Bunnell BA, Casteilla L, Jung JS, Yoshimura K. Phases I-III Clinical Trials Using Adult Stem Cells. Stem Cells Int. 2011;2010:604713.

32. Nygren JM, Jovinge S, Breitbach M, Sawen P, Roll W, Hescheler J, et al. Bone marrow-derived hematopoietic cells generate cardiomyocytes at a low 
frequency through cell fusion, but not transdifferentiation. Nat Med. 2004;10(5):494501.

33. Wei F, Wang T, Liu J, Du Y, Ma A. The subpopulation of mesenchymal stem cells that differentiate toward cardiomyocytes is cardiac progenitor cells. Exp Cell Res. 2011.

34. Park E, Patel AN. PKC-delta induces cardiomyogenic gene expression in human adipose-derived stem cells. Biochem Biophys Res Commun. 2010;393(4):582-6.

35. Lewitzky M, Yamanaka S. Reprogramming somatic cells towards pluripotency by defined factors. Curr Opin Biotechnol. 2007;18(5):467-73.

36. Galvao V, Miranda JG, Andrade RF, Andrade JS, Jr., Gallos LK, Makse HA. Modularity map of the network of human cell differentiation. Proc Natl Acad Sci U S A. $2010 ; 107(13): 5750-5$.

37. Fujimori T, Kurotaki Y, Miyazaki J, Nabeshima Y. Analysis of cell lineage in two- and four-cell mouse embryos. Development. 2003;130(21):5113-22.

38. Niwa H. How is pluripotency determined and maintained? Development. 2007;134(4):635-46.

39. Boyer LA, Mathur D, Jaenisch R. Molecular control of pluripotency. Curr Opin Genet Dev. 2006;16(5):455-62 .

40. Spivakov M, Fisher AG. Epigenetic signatures of stem-cell identity. Nat Rev Genet. 2007;8(4):263-71. 
41. Surani MA, Hayashi K, Hajkova P. Genetic and epigenetic regulators of pluripotency. Cell. 2007;128(4):747-62.

42. Wakayama T, Hayashi Y, Ogura A. Participation of the female pronucleus derived from the second polar body in full embryonic development of mice. J Reprod Fertil. 1997;110(2):263-6.

43. Cowan CA, Atienza J, Melton DA, Eggan K. Nuclear reprogramming of somatic cells after fusion with human embryonic stem cells. Science. $2005 ; 309(5739): 1369-73$.

44. Do JT, Scholer HR. Nuclei of embryonic stem cells reprogram somatic cells. Stem Cells. 2004;22(6):941-9.

45. Matsumura H, Tada M, Otsuji T, Yasuchika K, Nakatsuji N, Surani A, et al. Targeted chromosome elimination from ES-somatic hybrid cells. Nat Methods. $2007 ; 4(1): 23-5$.

46. Hansis C, Barreto G, Maltry N, Niehrs C. Nuclear reprogramming of human somatic cells by xenopus egg extract requires BRG1. Curr Biol. 2004;14(16):147580.

47. Freberg CT, Dahl JA, Timoskainen S, Collas P. Epigenetic reprogramming of OCT4 and NANOG regulatory regions by embryonal carcinoma cell extract. Mol Biol Cell. 2007;18(5):1543-53.

48. Taranger CK, Noer A, Sorensen AL, Hakelien AM, Boquest AC, Collas P. Induction of dedifferentiation, genomewide transcriptional programming, and epigenetic reprogramming by extracts of carcinoma and embryonic stem cells. Mol Biol Cell. 2005;16(12):5719-35. 
49. Takahashi K, Yamanaka S. Induction of pluripotent stem cells from mouse embryonic and adult fibroblast cultures by defined factors. Cell. 2006;126(4):663-76.

50. Okita K, Ichisaka T, Yamanaka S. Generation of germline-competent induced pluripotent stem cells. Nature. 2007;448(7151):313-7.

51. Meissner A, Wernig M, Jaenisch R. Direct reprogramming of genetically unmodified fibroblasts into pluripotent stem cells. Nat Biotechnol. 2007;25(10):117781.

52. Wernig M, Meissner A, Foreman R, Brambrink T, Ku M, Hochedlinger K, et al. In vitro reprogramming of fibroblasts into a pluripotent ES-cell-like state. Nature. 2007;448(7151):318-24.

53. Takahashi K, Tanabe K, Ohnuki M, Narita M, Ichisaka T, Tomoda K, et al. Induction of pluripotent stem cells from adult human fibroblasts by defined factors. Cell. 2007;131(5):861-72.

54. Lowry WE, Richter L, Yachechko R, Pyle AD, Tchieu J, Sridharan R, et al. Generation of human induced pluripotent stem cells from dermal fibroblasts. Proc Natl Acad Sci U S A. 2008.

55. Yu J, Vodyanik MA, Smuga-Otto K, Antosiewicz-Bourget J, Frane JL, Tian S, et al. Induced pluripotent stem cell lines derived from human somatic cells. Science. 2007;318(5858):1917-20.

56. Nakagawa M, Koyanagi M, Tanabe K, Takahashi K, Ichisaka T, Aoi T, et al. Generation of induced pluripotent stem cells without Myc from mouse and human fibroblasts. Nat Biotechnol. 2008;26(1):101-6. 
57. Han J, Yuan P, Yang H, Zhang J, Soh BS, Li P, et al. Tbx3 improves the germ-line competency of induced pluripotent stem cells. Nature. 2010;463(7284):1096-100.

58. Judson RL, Babiarz JE, Venere M, Blelloch R. Embryonic stem cell-specific microRNAs promote induced pluripotency. Nat Biotechnol. 2009;27(5):459-61.

59. Wadia JS, Dowdy SF. Protein transduction technology. Curr Opin Biotechnol. 2002;13(1):52-6.

60. Schwarze SR, Ho A, Vocero-Akbani A, Dowdy SF. In vivo protein transduction: delivery of a biologically active protein into the mouse. Science. 1999;285(5433):1569-72.

61. Chauhan A, Turchan J, Pocernich C, Bruce-Keller A, Roth S, Butterfield DA, et al. Intracellular human immunodeficiency virus Tat expression in astrocytes promotes astrocyte survival but induces potent neurotoxicity at distant sites via axonal transport. J Biol Chem. 2003;278(15):13512-9.

62. Green M, Loewenstein PM. Autonomous functional domains of chemically synthesized human immunodeficiency virus tat trans-activator protein. Cell. 1988;55(6):1179-88.

63. Chauhan A, Tikoo A, Kapur AK, Singh M. The taming of the cell penetrating domain of the HIV Tat: myths and realities. J Control Release. 2007;117(2):148-62.

64. Sugita T, Yoshikawa T, Mukai Y, Yamanada N, Imai S, Nagano K, et al. Comparative study on transduction and toxicity of protein transduction domains. $\mathrm{Br} \mathrm{J}$ Pharmacol. 2008. 
65. Grimmer S, van Deurs B, Sandvig K. Membrane ruffling and macropinocytosis in A431 cells require cholesterol. J Cell Sci. 2002;115(Pt 14):2953-62.

66. West MA, Bretscher MS, Watts C. Distinct endocytotic pathways in epidermal growth factor-stimulated human carcinoma A431 cells. J Cell Biol. 1989;109(6 Pt 1):2731-9.

67. Fischer R, Kohler K, Fotin-Mleczek M, Brock R. A stepwise dissection of the intracellular fate of cationic cell-penetrating peptides. J Biol Chem. 2004;279(13):12625-35.

68. Schneider C, Sepp-Lorenzino L, Nimmesgern E, Ouerfelli O, Danishefsky S, Rosen N, et al. Pharmacologic shifting of a balance between protein refolding and degradation mediated by Hsp90. Proc Natl Acad Sci U S A. 1996;93(25):14536-41.

69. Cardarelli F, Serresi M, Albanese A, Bizzarri R, Beltram F. Quantitative analysis of Tat peptide binding to import carriers reveals unconventional nuclear transport properties. J Biol Chem. 2011;286(14):12292-9.

70. Neukamm B, Miyakawa AA, Fukada SY, Andrade CRd, Pacheco FP, Silva TGd, et al. Local TAT-p27Kip1 Fusion Protein inhibits cell proliferation in rat carotid arteries. Therapeutics Advances in Cardiovascular Disease. 2008;2(3):1-8.

71. Nagahara H, Vocero-Akbani AM, Snyder EL, Ho A, Latham DG, Lissy NA, et al. Transduction of full-length TAT fusion proteins into mammalian cells: TATp27Kip1 induces cell migration. Nat Med. 1998;4(12):1449-52.

72. Lu Y, Mahato RI. Pharmaceutical perspectives of cancer therapeutics. Dordrecht ; New York 
Arlington, Va.: Springer ;

AAPS Press; 2009.

73. Campos-Lisboa AC, Mares-Guia TR, Grazioli G, Goldberg AC, Sogayar MC. Biodritin microencapsulated human islets of Langerhans and their potential for type 1 diabetes mellitus therapy. Transplant Proc. 2008;40(2):433-5.

74. Nikcevic G, Kovacevic-Grujicic N, Stevanovic M. Improved transfection efficiency of cultured human cells. Cell Biol Int. 2003;27(9):735-7.

75. Germeraad WT, Asami N, Fujimoto S, Mazda O, Katsura Y. Efficient retrovirus-mediated gene transduction into murine hematopoietic stem cells and long-lasting expression using a Transwell coculture system. Blood. 1994;84(3):7808.

76. Flinterman M, Farzaneh F, Habib N, Malik F, Gaken J, Tavassoli M. Delivery of therapeutic proteins as secretable TAT fusion products. Mol Ther. 2009;17(2):334-42.

77. Okita K, Nakagawa M, Hyenjong H, Ichisaka T, Yamanaka S. Generation of mouse induced pluripotent stem cells without viral vectors. Science. 2008;322(5903):949-53 .

78. Stadtfeld M, Nagaya M, Utikal J, Weir G, Hochedlinger K. Induced pluripotent stem cells generated without viral integration. Science. 2008;322(5903):945-9.

79. Papapetrou EP, Tomishima MJ, Chambers SM, Mica Y, Reed E, Menon J, et al. Stoichiometric and temporal requirements of Oct4, Sox2, Klf4, and c-Myc expression for efficient human iPSC induction and differentiation. Proc Natl Acad Sci U S A. 2009;106(31):12759-64. 
80. Wang Q, Xu X, Li J, Liu J, Gu H, Zhang R, et al. Lithium, an anti-psychotic drug, greatly enhances the generation of induced pluripotent stem cells. Cell Res. 2011;21(10):1424-35.

81. Huangfu D, Osafune K, Maehr R, Guo W, Eijkelenboom A, Chen S, et al. Induction of pluripotent stem cells from primary human fibroblasts with only Oct4 and Sox2. Nat Biotechnol. 2008;26(11):1269-75.

82. Yoshida Y, Takahashi K, Okita K, Ichisaka T, Yamanaka S. Hypoxia enhances the generation of induced pluripotent stem cells. Cell Stem Cell. $2009 ; 5(3): 237-41$.

83. Mohyeldin A, Garzon-Muvdi T, Quinones-Hinojosa A. Oxygen in stem cell biology: a critical component of the stem cell niche. Cell Stem Cell. 2010;7(2):15061.

84. Danoviz ME, Bassaneze V, Nakamuta JS, dos Santos-Junior GR, Saint-Clair D, Bajgelman MC, et al. Adipose tissue-derived stem cells from humans and mice differ in proliferative capacity and genome stability in long-term cultures. Stem Cells Dev. 2011;20(4):661-70.

85. Bassaneze V, Barauna VG, Lavini-Ramos C, Kalil J, Schettert IT, Miyakawa AA, et al. Shear stress induces nitric oxide-mediated vascular endothelial growth factor production in human adipose tissue mesenchymal stem cells. Stem Cells Dev. 2010;19(3):371-8.

86. Blande IS, Bassaneze V, Lavini-Ramos C, Fae KC, Kalil J, Miyakawa AA, et al. Adipose tissue mesenchymal stem cell expansion in animal serum-free medium supplemented with autologous human platelet lysate. Transfusion. $2009 ; 49(12): 2680-5$. 
87. Sukoyan MA, Kerkis AY, Mello MR, Kerkis IE, Visintin JA, Pereira LV. Establishment of new murine embryonic stem cell lines for the generation of mouse models of human genetic diseases. Braz J Med Biol Res. 2002;35(5):535-42.

88. Boheler KR. ES cell differentiation to the cardiac lineage. Methods Enzymol. 2003;365:228-41.

89. Takashima A. Establishment of Fibroblast Cultures. Dallas, Texas2001.

90. Takahashi K, Okita K, Nakagawa M, Yamanaka S. Induction of pluripotent stem cells from fibroblast cultures. Nat Protoc. 2007;2(12):3081-9.

91. Ma Y, Ramezani A, Lewis R, Hawley RG, Thomson JA. High-level sustained transgene expression in human embryonic stem cells using lentiviral vectors. Stem Cells. 2003;21(1):111-7.

92. Sommer CA, Stadtfeld M, Murphy GJ, Hochedlinger K, Kotton DN, Mostoslavsky G. Induced pluripotent stem cell generation using a single lentiviral stem cell cassette. Stem Cells. 2009;27(3):543-9.

93. Malek AM, Gibbons GH, Dzau VJ, Izumo S. Fluid shear stress differentially modulates expression of genes encoding basic fibroblast growth factor and plateletderived growth factor B chain in vascular endothelium. J Clin Invest. 1993;92(4):2013-21.

94. Malek A, Izumo S. Physiological fluid shear stress causes downregulation of endothelin-1 mRNA in bovine aortic endothelium. Am J Physiol. 1992;263(2 Pt 1):C389-96. 
95. Naviaux RK, Costanzi E, Haas M, Verma IM. The pCL vector system: rapid production of helper-free, high-titer, recombinant retroviruses. J Virol. 1996;70(8):5701-5.

96. Chen $\mathrm{C}$, Okayama $\mathrm{H}$. High-efficiency transformation of mammalian cells by plasmid DNA. Mol Cell Biol. 1987;7(8):2745-52.

97. Hu SI, Macintyre SS, Schultz D, Kushner I, Samols D. Secretion of rabbit Creactive protein by transfected human cell lines is more rapid than by cultured rabbit hepatocytes. J Biol Chem. 1988;263(3):1500-4.

98. Yusa K, Rad R, Takeda J, Bradley A. Generation of transgene-free induced pluripotent mouse stem cells by the piggyBac transposon. Nat Methods. 2009;6(5):363-9.

99. Teng HF, Kuo YL, Loo MR, Li CL, Chu TW, Suo H, et al. Valproic acid enhances Oct4 promoter activity in myogenic cells. J Cell Biochem. 2010;110(4):995-1004.

100. Sinacore MS, Drapeau D, Adamson SR. Adaptation of mammalian cells to growth in serum-free media. Mol Biotechnol. 2000;15(3):249-57.

101. Mallon BS, Park KY, Chen KG, Hamilton RS, McKay RD. Toward xeno-free culture of human embryonic stem cells. Int J Biochem Cell Biol. 2006;38(7):1063-75.

102. Villa-Diaz LG, Pacut C, Slawny NA, Ding J, O'Shea KS, Smith GD. Analysis of the factors that limit the ability of feeder cells to maintain the undifferentiated state of human embryonic stem cells. Stem Cells Dev. 2009;18(4):641-51. 
103. Gough NM, Williams RL, Hilton DJ, Pease S, Willson TA, Stahl J, et al. LIF: a molecule with divergent actions on myeloid leukaemic cells and embryonic stem cells. Reprod Fertil Dev. 1989;1(4):281-8.

104. Williams RL, Hilton DJ, Pease S, Willson TA, Stewart CL, Gearing DP, et al. Myeloid leukaemia inhibitory factor maintains the developmental potential of embryonic stem cells. Nature. 1988;336(6200):684-7.

105. Morrison GM, Oikonomopoulou I, Migueles RP, Soneji S, Livigni A, Enver T, et al. Anterior definitive endoderm from ESCs reveals a role for FGF signaling. Cell Stem Cell. 2008;3(4):402-15.

106. Hadjantonakis AK, Macmaster S, Nagy A. Embryonic stem cells and mice expressing different GFP variants for multiple non-invasive reporter usage within a single animal. BMC Biotechnol. 2002;2:11.

107. lacobas I, Vats A, Hirschi KK. Vascular potential of human pluripotent stem cells. Arterioscler Thromb Vasc Biol. 2010;30(6):1110-7.

108. Sakamoto H, Tsuji-Tamura K, Ogawa M. Hematopoiesis from pluripotent stem cell lines. Int J Hematol. 2010;91(3):384-91.

109. Sun N, Panetta NJ, Gupta DM, Wilson KD, Lee A, Jia F, et al. Feeder-free derivation of induced pluripotent stem cells from adult human adipose stem cells. Proc Natl Acad Sci U S A. 2009;106(37):15720-5.

110. Zhou H, Wu S, Joo JY, Zhu S, Han DW, Lin T, et al. Generation of induced pluripotent stem cells using recombinant proteins. Cell Stem Cell. 2009;4(5):381-4.

111. Wernig M, Meissner A, Cassady JP, Jaenisch R. C-Myc is dispensable for direct reprogramming of mouse fibroblasts. Cell Stem Cell. 2008;2(1):10-2. 
112. Chandra A, Barillas S, Suliman A, Angle N. A novel fluorescence-based cellular permeability assay. J Biochem Biophys Methods. 2007;70(3):329-33.

113. Berginc K, Kristl A. Transwell-Grown HepG2 Cell Monolayers as In Vitro Permeability Model to Study Drug-Drug or Drug-Food Interactions. J Med Food. 2011;14(1-2):135-9.

114. Miller MF, Loch-Caruso R. Comparison of LPS-stimulated release of cytokines in punch versus transwell tissue culture systems of human gestational membranes. Reprod Biol Endocrinol. 2010;8:121.

115. Vucic V, Isenovic ER, Adzic M, Ruzdijic S, Radojcic MB. Effects of gammaradiation on cell growth, cycle arrest, death, and superoxide dismutase expression by DU 145 human prostate cancer cells. Braz J Med Biol Res. 2006;39(2):227-36.

116. Bohnke A, Westphal F, Schmidt A, El-Awady RA, Dahm-Daphi J. Role of p53 mutations, protein function and DNA damage for the radiosensitivity of human tumour cells. Int J Radiat Biol. 2004;80(1):53-63.

117. Hooper C, Meimaridou E, Tavassoli M, Melino G, Lovestone S, Killick R. p53 is upregulated in Alzheimer's disease and induces tau phosphorylation in HEK293a cells. Neurosci Lett. 2007;418(1):34-7.

118. Hamid T, Kakar SS. PTTG/securin activates expression of p53 and modulates its function. Mol Cancer. 2004;3:18.

119. Garcia-Gonzalo FR, Izpisua Belmonte JC. Albumin-associated lipids regulate human embryonic stem cell self-renewal. PLoS One. 2008;3(1):e1384. 
120. Cheng J, Dutra A, Takesono A, Garrett-Beal L, Schwartzberg PL. Improved generation of $\mathrm{C} 57 \mathrm{BL} / 6 \mathrm{~J}$ mouse embryonic stem cells in a defined serum-free media. Genesis. 2004;39(2):100-4.

121. Okada M, Oka M, Yoneda Y. Effective culture conditions for the induction of pluripotent stem cells. Biochimica et biophysica acta. 2010;1800(9):956-63.

122. Shaw PA, Catchpole IR, Goddard CA, Colledge WH. Comparison of protein transduction domains in mediating cell delivery of a secreted CRE protein. Biochemistry. 2008;47(4):1157-66.

123. Jenkins N, Parekh RB, James DC. Getting the glycosylation right: implications for the biotechnology industry. Nat Biotechnol. 1996;14(8):975-81.

124. Kane R, Murtagh J, Finlay D, Marti A, Jaggi R, Blatchford D, et al. Transcription factor NFIC undergoes N-glycosylation during early mammary gland involution. J Biol Chem. 2002;277(29):25893-903.

125. Jackson SP, Tjian R. O-glycosylation of eukaryotic transcription factors: implications for mechanisms of transcriptional regulation. Cell. 1988;55(1):125-33.

126. Hansen JE, Lund O, Tolstrup N, Gooley AA, Williams KL, Brunak S. NetOglyc: prediction of mucin type O-glycosylation sites based on sequence context and surface accessibility. Glycoconj J. 1998;15(2):115-30.

127. Julenius K, Molgaard A, Gupta R, Brunak S. Prediction, conservation analysis, and structural characterization of mammalian mucin-type O-glycosylation sites. Glycobiology. 2005;15(2):153-64.

128. Hamby SE, Hirst JD. Prediction of glycosylation sites using random forests. BMC Bioinformatics. 2008;9:500. 
129. Gao F, Kwon SW, Zhao Y, Jin Y. PARP1 poly(ADP-ribosyl)ates Sox2 to control Sox2 protein levels and FGF4 expression during embryonic stem cell differentiation. J Biol Chem. 2009;284(33):22263-73.

130. Konno M, Masui S, Hamazaki TS, Okochi H. Intracellular reactivation of transcription factors fused with protein transduction domain. J Biotechnol. 2011.

131. Tang Y, Lin CJ, Tian XC. Functionality and transduction condition evaluation of recombinant Klf4 for improved reprogramming of iPS cells. Cell Reprogram. 2011;13(2):99-112.

132. Cho HJ, Lee CS, Kwon YW, Paek JS, Lee SH, Hur J, et al. Induction of pluripotent stem cells from adult somatic cells by protein-based reprogramming without genetic manipulation. Blood. [Research Support, Non-U.S. Gov't]. 2010;116(3):386-95.

133. Caron NJ, Quenneville SP, Tremblay JP. Endosome disruption enhances the functional nuclear delivery of Tat-fusion proteins. Biochem Biophys Res Commun. $2004 ; 319(1): 12-20$.

134. Fischer R, Fotin-Mleczek M, Hufnagel $H$, Brock R. Break on through to the other side-biophysics and cell biology shed light on cell-penetrating peptides. Chembiochem. 2005;6(12):2126-42.

135. Zhou W, Freed CR. Adenoviral gene delivery can reprogram human fibroblasts to induced pluripotent stem cells. Stem Cells. 2009;27(11):2667-74.

136. Fusaki N, Ban H, Nishiyama A, Saeki K, Hasegawa M. Efficient induction of transgene-free human pluripotent stem cells using a vector based on Sendai virus, 
an RNA virus that does not integrate into the host genome. Proc Jpn Acad Ser B Phys Biol Sci. 2009;85(8):348-62.

137. Ban H, Nishishita N, Fusaki N, Tabata T, Saeki K, Shikamura M, et al. Efficient generation of transgene-free human induced pluripotent stem cells (iPSCs) by temperature-sensitive Sendai virus vectors. Proc Natl Acad Sci U S A. $2011 ; 108(34): 14234-9$.

138. Yu J, Hu K, Smuga-Otto K, Tian S, Stewart R, Slukvin, II, et al. Human induced pluripotent stem cells free of vector and transgene sequences. Science. 2009;324(5928):797-801.

139. Kaji K, Norrby K, Paca A, Mileikovsky M, Mohseni P, Woltjen K. Virus-free induction of pluripotency and subsequent excision of reprogramming factors. Nature. 2009;458(7239):771-5.

140. Woltjen K, Michael IP, Mohseni P, Desai R, Mileikovsky M, Hamalainen R, et al. piggyBac transposition reprograms fibroblasts to induced pluripotent stem cells. Nature. 2009;458(7239):766-70.

141. Carey BW, Markoulaki S, Hanna J, Saha K, Gao Q, Mitalipova M, et al. Reprogramming of murine and human somatic cells using a single polycistronic vector. Proc Natl Acad Sci U S A. 2009;106(1):157-62.

142. Desponts C, Ding S. Using small molecules to improve generation of induced pluripotent stem cells from somatic cells. Methods Mol Biol. 2010;636:207-18.

143. Yakubov E, Rechavi G, Rozenblatt S, Givol D. Reprogramming of human fibroblasts to pluripotent stem cells using mRNA of four transcription factors. Biochem Biophys Res Commun.394(1):189-93. 
144. Warren L, Manos PD, Ahfeldt T, Loh YH, Li H, Lau F, et al. Highly efficient reprogramming to pluripotency and directed differentiation of human cells with synthetic modified mRNA. Cell Stem Cell. 2010;7(5):618-30.

145. Plews JR, Li J, Jones M, Moore HD, Mason C, Andrews PW, et al. Activation of pluripotency genes in human fibroblast cells by a novel mRNA based approach. PLoS One. 2010;5(12):e14397.

146. Kunisato A, Wakatsuki M, Kodama Y, Shinba H, Ishida I, Nagao K. Generation of induced pluripotent stem (iPS) cells by efficient reprogramming of adult bone marrow cells. Stem Cells Dev. 2009.

147. Kim D, Kim CH, Moon JI, Chung YG, Chang MY, Han BS, et al. Generation of human induced pluripotent stem cells by direct delivery of reprogramming proteins. Cell Stem Cell. 2009;4(6):472-6.

148. Blancas AA, Lauer NE, McCloskey KE. Endothelial differentiation of embryonic stem cells. Curr Protoc Stem Cell Biol. 2008;Chapter 1:Unit 1F 5.

149. Xie CQ, Huang H, Wei S, Song LS, Zhang J, Ritchie RP, et al. A comparison of murine smooth muscle cells generated from embryonic versus induced pluripotent stem cells. Stem Cells Dev. 2009;18(5):741-8.

150. Yoon BS, Yoo SJ, Lee JE, You S, Lee HT, Yoon HS. Enhanced differentiation of human embryonic stem cells into cardiomyocytes by combining hanging drop culture and 5-azacytidine treatment. Differentiation. 2006;74(4):14959. 
151. Laflamme MA, Chen KY, Naumova AV, Muskheli V, Fugate JA, Dupras SK, et al. Cardiomyocytes derived from human embryonic stem cells in pro-survival factors enhance function of infarcted rat hearts. Nat Biotechnol. 2007;25(9):1015-24.

152. Blin G, Nury D, Stefanovic S, Neri T, Guillevic O, Brinon B, et al. A purified population of multipotent cardiovascular progenitors derived from primate pluripotent stem cells engrafts in postmyocardial infarcted nonhuman primates. J Clin Invest. 2010;120(4):1125-39.

153. Li X, Yu X, Lin Q, Deng C, Shan Z, Yang M, et al. Bone marrow mesenchymal stem cells differentiate into functional cardiac phenotypes by cardiac microenvironment. J Mol Cell Cardiol. 2007;42(2):295-303.

154. Mummery C, Ward-van Oostwaard D, Doevendans P, Spijker R, van den Brink S, Hassink R, et al. Differentiation of human embryonic stem cells to cardiomyocytes: role of coculture with visceral endoderm-like cells. Circulation. 2003;107(21):2733-40.

155. Passier R, Oostwaard DW, Snapper J, Kloots J, Hassink RJ, Kuijk E, et al. Increased cardiomyocyte differentiation from human embryonic stem cells in serumfree cultures. Stem Cells. 2005;23(6):772-80.

156. Gonzalez F, Barragan Monasterio M, Tiscornia G, Montserrat Pulido N, Vassena R, Batlle Morera L, et al. Generation of mouse-induced pluripotent stem cells by transient expression of a single nonviral polycistronic vector. Proc Natl Acad Sci U S A. 2009;106(22):8918-22.

157. Ohi Y, Qin H, Hong C, Blouin L, Polo JM, Guo T, et al. Incomplete DNA methylation underlies a transcriptional memory of somatic cells in human iPS cells. Nat Cell Biol. 2011;13(5):541-9. 
158. Zadeh LA. FUZZY SETS. Information and Control. [Article]. 1965;8(3):338-\&.

159. Pereira JC, Tonelli PA, Barros LC, Ortega NR. Clinical signs of pneumonia in children: association with and prediction of diagnosis by fuzzy sets theory. Braz $\mathrm{J}$ Med Biol Res. 2004;37(5):701-9.

160. Massad EaO, Neli R.S. and Barros, Lacio C. and Struchiner, Cludio J. Fuzzy Logic in Action: Applications in Epidemiology and Beyond: Springer Publishing Company, Incorporated; 2009.

161. Landis JR, Koch GG. The measurement of observer agreement for categorical data. Biometrics. 1977;33(1):159-74. 


\section{Apêndices}




\section{Apêndice I - Resultados suplementares}

\section{Avaliação do efeito de 3 (OSK) ou 4 fatores (OSKM) no tamanho das colônias} após 30 dias da infecção retroviral

Colônias iPS murinas foram obtidas utilizando-se 3 ou 4 fatores de transcrição (pMX) e foram avaliadas as dimensões de diâmetro dessas colônias com objetivo de verificar se havia sua associação com o fato delas serem verdadeiras ou não (Figura suplementar 1).

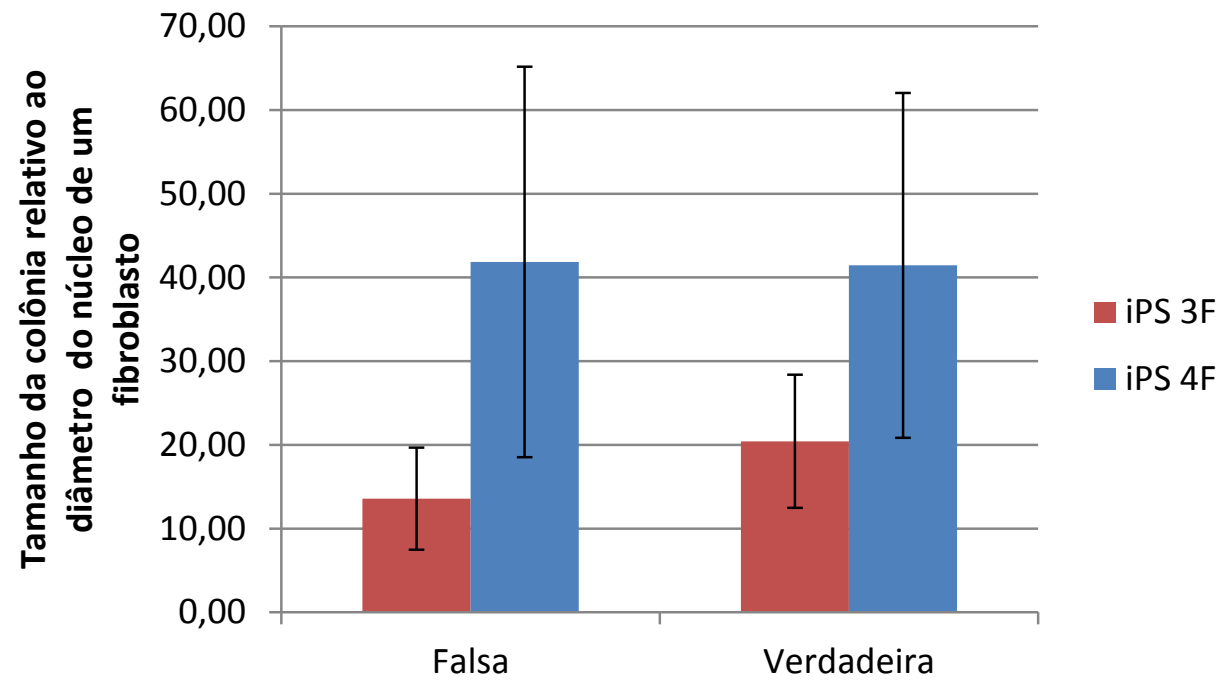

Figura suplementar 1: cMYC tem efeito pronunciado na proliferação das colônias de iPS murinas. Células iPS geradas com e sem o gene cMYC foram avaliadas quanto ao seu diâmetro (médias dos eixos maiores de menores, quando colônias ovaladas, apresentados de forma relativa ao núcleo de um fibroblasto da camada feeder) e se eram verdadeiras (fosfatase alcalina ${ }^{+}$) ou não. Apenas as diferenças entre os números de vírus são significativas. Média $\pm \mathrm{EPM},(\mathrm{N}=136$ colônias).

Como pode ser observado, apenas a presença do cMyc promove uma diferença significativa na medida de tamanho das colônias. No caso das iPS com 3 fatores, há uma tendência das colônias maiores serem verdadeiras, contudo o efeito é discreto e não estatisticamente significativo. 
Diferenciação das células iPS murinas nos fenótipos vasculares.

\section{Endotelial}

A formação de corpos embrióides (EB) é uma maneira de se estimular as células a sofrerem um processo estocástico de diferenciação celular em um ambiente tridimensional. Nesse processo, as células pluripotentes se diferenciam em precursores endoteliais (dentre outros), os quais poderiam ser estimulados a se diferenciar em células endoteliais e a proliferar usando um meio específico para células endoteliais (meio EGM2, Lonza). Esse processo foi realizado e após seis dias em cultura conseguiu-se obter células com morfologia cobblestone, muito semelhante às células endoteliais (Figura suplementar 2).

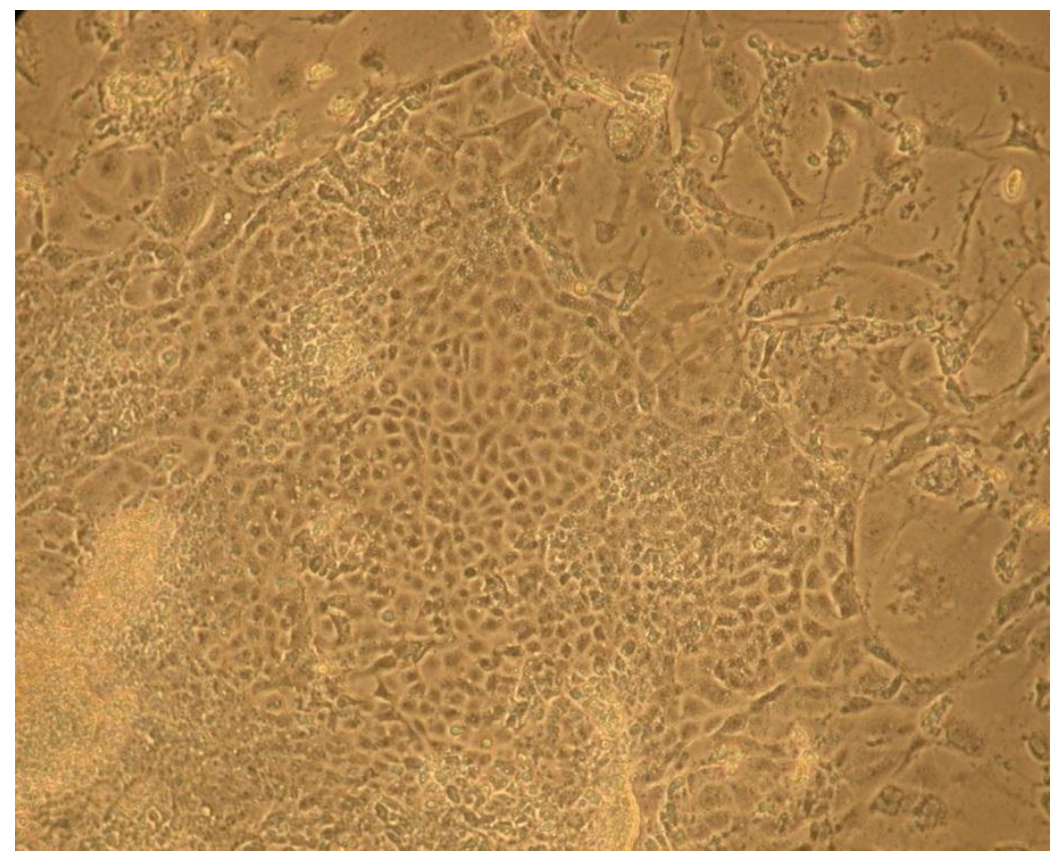

Figura suplementar 2: Imagem em aumento de 100x de células derivadas da iPS 40p20 GFP+ após 7 dias em formação de corpo embrióide e 6 dias em cultura com meio EGM2. Morfologia cooblestone é bastante sugestiva de que sejam células endoteliais.

Procurou-se realizar ensaio de imunofluorescência para CD31 e fator VIII para confirmar a sua identificação, contudo as células não resistiram ao processo de 
repique. $\mathrm{O}$ experimento será repetido futuramente mais vezes e já diretamente na lamínula, para facilitar o ensaio posterior. Uma alternativa para obter células endoteliais derivadas das iPS pode ser mediante o plaqueamento em placas recobertas com colágeno IV. Depois de mantidas em meio sem LIF por 4 dias devem aparecer células $\mathrm{FLK}-1^{+}$, que são precursoras endoteliais, e que, ao serem tratadas com VEGF, se transformam em células endoteliais maduras ${ }^{148}$.

\section{Shear Stress}

Procurou-se confirmar se as iPS são passíveis à diferenciação ao fenótipo endotelial quando submetidas ao shear stress. Foram plaqueadas $1,5 \times 10^{6}$ células em placas de $150 \mathrm{~mm}$ com feeder e submetidas a shear laminar 10 dinas $/ \mathrm{cm}^{2}$ por 1,2 e 7 dias $(\mathrm{n}=2)$. Como pode ser observado na figura suplementar $\mathbf{3}$, após os sete dias observa-se na cultura o aparecimento de células com morfologia muito distinta do controle estático. Foram realizados experimentos de RT-PCR com essas células, contudo observou-se expressão de FLK nas células MEF (controle negativo) também, deixando o experimento inconclusivo (dados não mostrados). Ele será repetido e analisado por citometria de fluxo para CD31, FLK e vWF. Além disso, as feeder (MEF) serão retiradas do experimento, pois podem estar dificultando a diferenciação pela produção de LIF. 

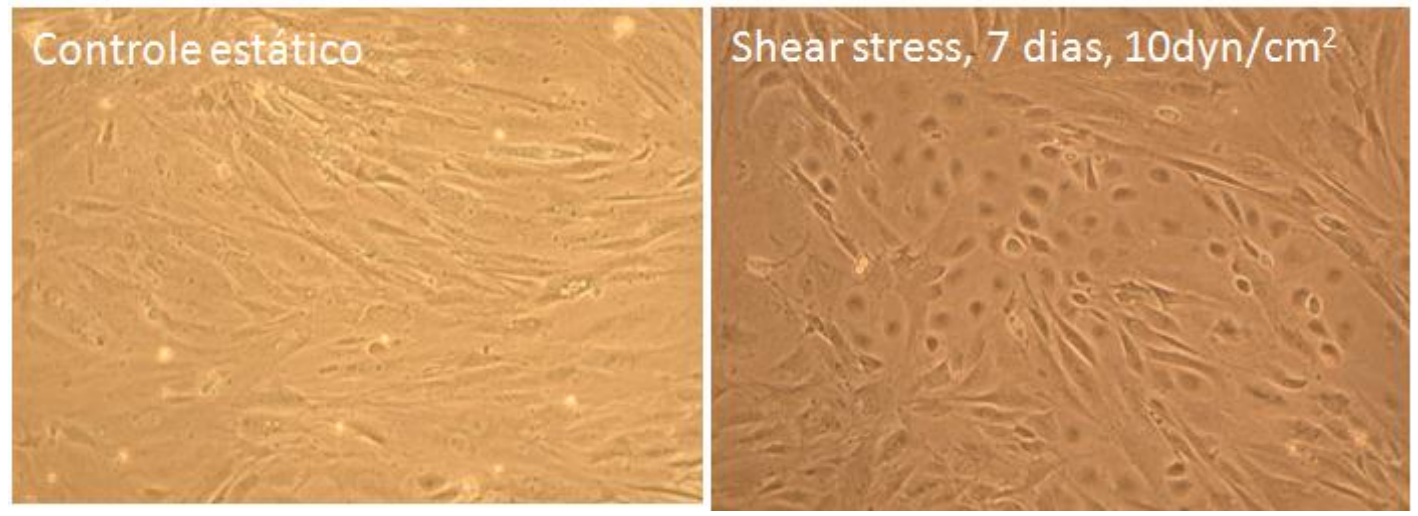

Figura suplementar 3: Shear stress nas células iPS. Imagens representativas de células iPS submetidas a shear stress de $10 \mathrm{dyn} / \mathrm{cm}^{2}$ após 7 dias. As formações não eram homogêneas na placa, mas estava presente em mais de um local (aumento de 100x).

\section{Muscular lisa}

Uma recente publicação ${ }^{149}$ demonstrou que células ES ou iPS em cultivo sob meio de diferenciação (F12:DMEM $+10 \%$ FBS + L-glutamina + MEM $+\beta$ mercaptoetanol + Ácido Retinóico a $10^{-5} \mathrm{M}$ ) na ausência de feeder por até 9 dias apresentam uma diferenciação maciça em células musculares lisas de vasos (SMC). Foi realizada uma tentativa com esse protocolo, contudo ainda não foi obtido sucesso

\section{(figura suplementar 4).}
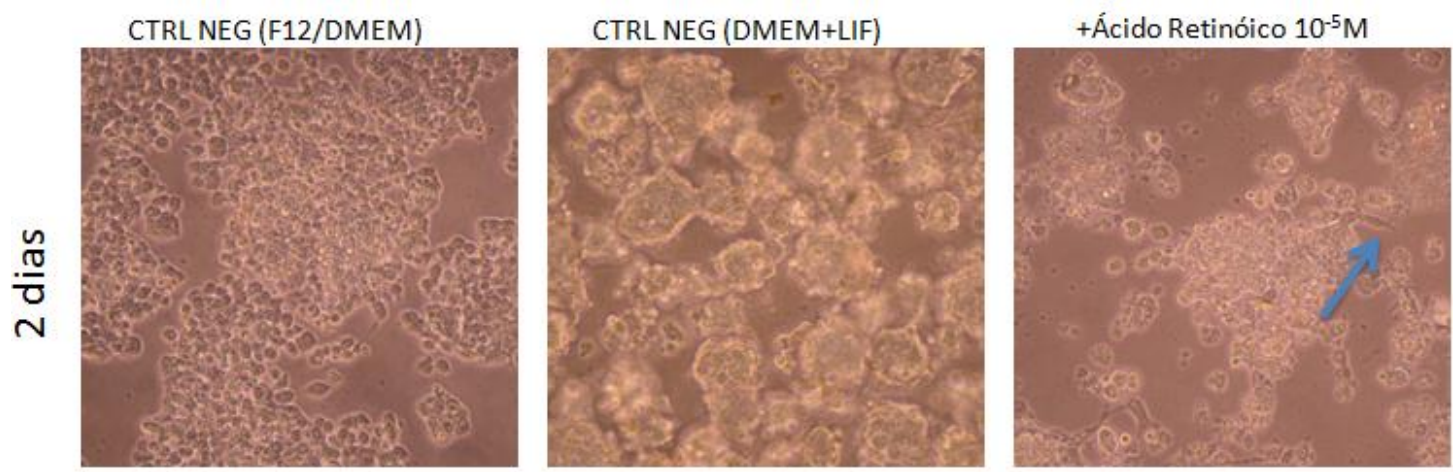

Figura suplementar 4: Imagem em aumento de 100x de células iPS tratadas com ácido retinóico para se diferenciar em células musculares lisas de vaso. Seta indica uma possível célula muscular lisa. 
As células apresentaram grande variação na morfologia com o tratamento com ácido retinóico. Apareceram inclusive algumas células com morfologia semelhantes às SMC, contudo após 4-5 dias, observou-se uma morte celular muito grande e a placa foi perdida.

\section{Cardiomiócitos}

A diferenciação em cardiomiócitos apresenta diversos protocolos distintos na literatura. O mais utilizado é o hanging drop, uma variação mais elegante para formação de corpos embrióides ${ }^{150}$. Além disso, há tratamento com citocinas como BMP4 e activin A ${ }^{151}$ ou BMP2 e inibidores de FGF2 ${ }^{152}$. Existem também relatos de diferenciação ao se fazer co-cultura com cardiomiócitos neonatais de ratos ${ }^{153}$, 154. Tentou-se fazer esse processo tanto por hanging drop como por co-cultura (figura suplementar 5) variando inclusive a concentração de FBS, que parece ser um fator importante na eficiência do processo de diferenciação ${ }^{155}$.

Foram feitas cinco tentativas de hanging drop, e não foi possível observar contração celular após até 3 dias do plaqueamento em placa recoberta com gelatina. Devida à contração dos próprios cardiomiócitos da cultura, não é possível saber se houve diferenciação das iPS. Ambos os experimentos foram coletados para análise de RT-PCR que será feita em breve. 
A) HD um dia após coleta

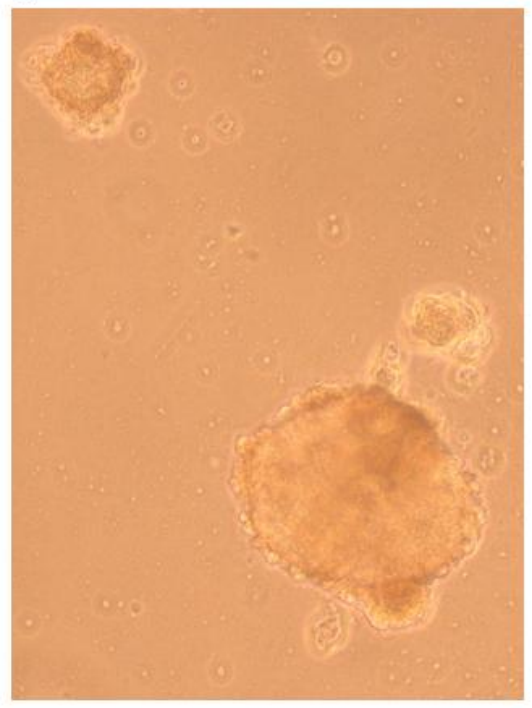

B)

Co-cultura com cardiomiócitos
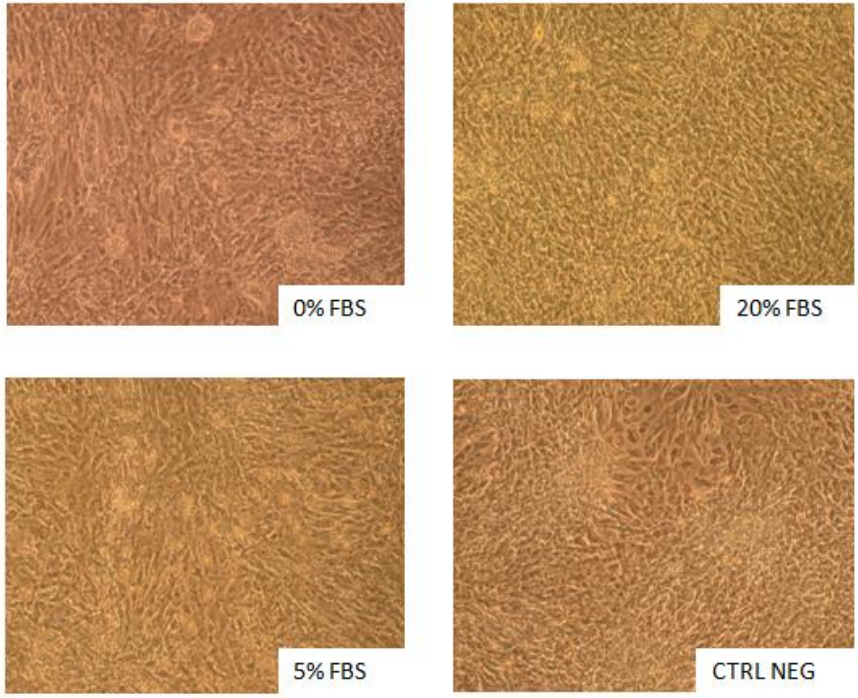

Figura suplementar 5: Diferenciação em cardiomiócitos.

Imagens representativas de (A) iPS em formação de hangin'n'drop e (B) em cocultura com cardiomiocitos neonatais de ratos, com diferentes quantidades de FBS (aumento de 100x). 
Apêndice II - Script para criação de gráficos de barras em três dimensões contendo barra de erros.

Para criar os gráficos com barras de erros das figuras 29 e 30, foi utilizado o script abaixo no MATLAB versão 7.11, obtido e adaptado da internet a partir do seguinte site:

http://illigal.blogspot.com/2005/01/matlab-script-for-3d-bar-plot-with.html (Encurtado para http://migre.me/6f3tE)

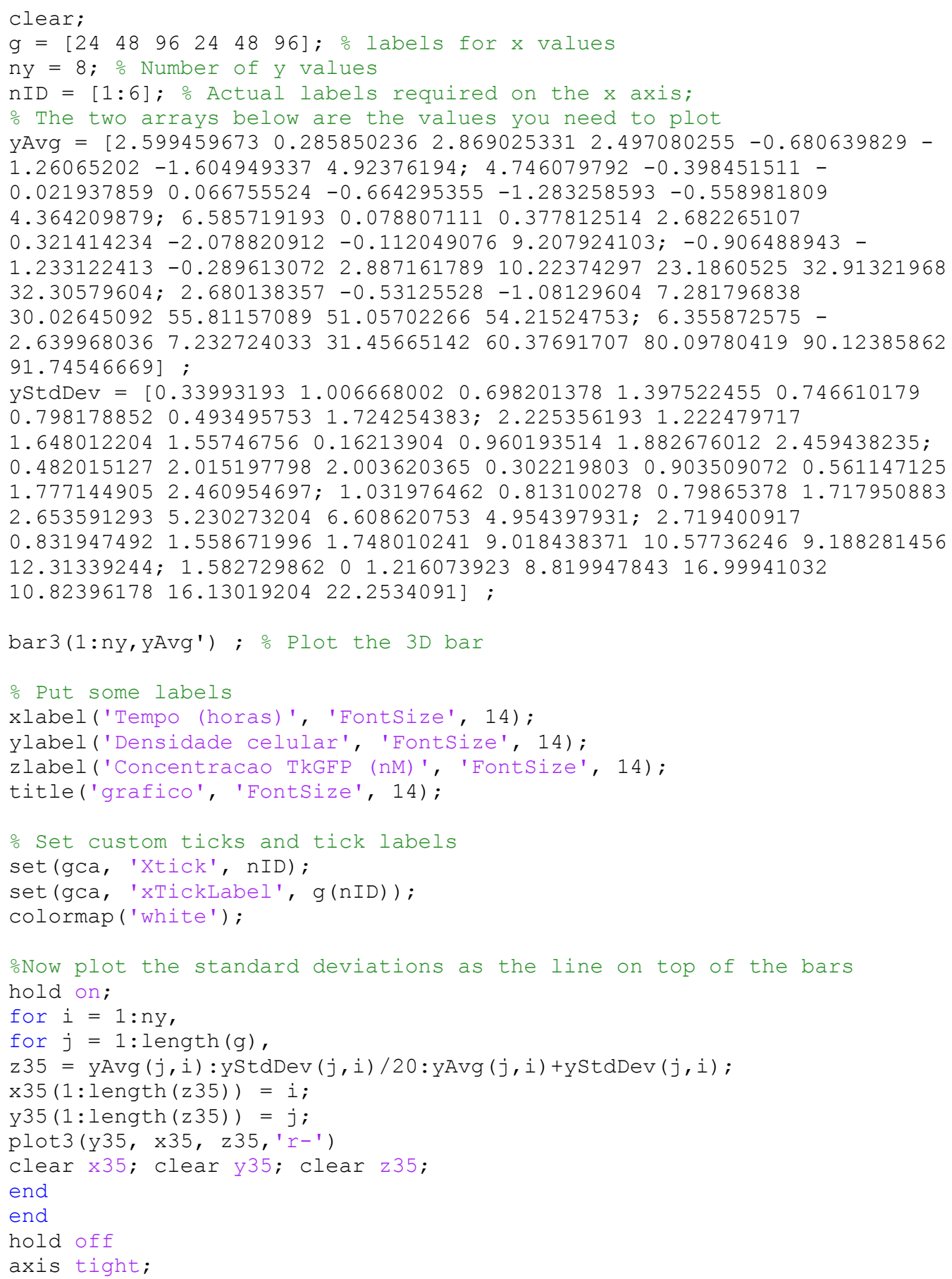


Apêndice III - Desenvolvimento de uma nova abordagem para auxiliar na identificação visual de colônias de iPS murinas usando lógica fuzzy.

\section{Introdução}

\subsection{Identificação de colônias de células iPS}

Identificar visualmente colônias de células iPS na placa de cultura assim que elas começam a se formar pode ser uma tarefa difícil a olhos destreinados, devido ao seu tamanho. Mais complexo ainda pode ser identificar quais delas são verdadeiras, isto é, que apresentarão as mesmas características de células ES depois de coletadas e expandidas. De acordo com a literatura, cerca de 75 a $88 \%$ das colônias que aparecem na placa após a transdução viral são provavelmente falsas, não apresentando a morfologia característica de células ES após coletadas, possivelmente devido ao processo de reprogramação não ter sido completo ou ter sido defectivo ${ }^{52}$. É curioso que ainda que algumas colônias verdadeiras inicialmente não lembrem morfologicamente as colônias de células ES, elas podem passar a adquirir essa morfologia após 1-2 passagens ${ }^{156}$. Além de proliferar, para definir de maneira definitiva que a reprogramação aconteceu de maneira completa é necessário que as colônias apresentem similaridades o maior possível em relação às ES em ensaios de avaliação de expressão gênica global, perfil de metilação epigenética, além do potencial de gerar teratomas quando injetadas em animal nude e a capacidade plena de gerar animais quiméricos férteis quando injetadas em blastocisto. E ainda assim tem sido possível encontrar diferenças importantes entre elas e as células ES ${ }^{157}$.

Avaliar todas essas similaridades é bastante trabalhoso e de alto custo. $\mathrm{Na}$ prática, a identificação inicial de colônias com potencial de terem sido verdadeiramente reprogramadas é minimamente realizada utilizando-se sistemas de genes repórter de resistência a antibiótico ou com probe fluorescente para os fatores 
de transcrição de células ES Fbox $15^{49}$, Nanog e OCT3/4 ${ }^{52}$ (dentre outros) ou a partir de ensaios simples, como a verificação da expressão de fosfatase alcalina e de marcadores moleculares. Os sistemas apresentam a facilidade de permitir a identificação das colônias no microscópio fluorescência antes de coleta, sem destruílas (ao contrário da fosfatase alcalina e RT-PCR de marcadores), contudo, eles só podem ser encontrados em células derivadas de animais transgênicos contendo esses sistemas, ou células de cultura primária previamente tratadas com vírus, para introduzi-los no seu genoma.

Isso pode representar um problema na prática do laboratório, quando é necessário coletar um grande número de colônias e, na sequência, ter que validá-las quanto à sua pluripotência. Ainda mais quando não for adequado para o experimento promover a introdução de novos elementos no genoma dessas células, como pode acontecer quando se está trabalhando com células de humanos com a pretensão futura de aplicá-las na prática clínica. Portanto, identificar novas abordagens para realização de triagem com acurácia antes de efetuar coleta de colônia é de bastante interesse. Ao longo do desenvolvimento dessa tese, foi observado que as colônias apresentavam uma diversidade morfológica grande antes da coleta e levantou-se a hipótese de que as diferenças observadas estivessem associadas com o fato de elas serem verdadeiras ou não. Se essa hipótese se mostrasse verdadeira, seria possível usar essa informação visual como elemento na primeira tomada de decisão da coleta ou não de uma determinada colônia de células, reduzindo parte do trabalho e do custo da coleta de colônias falsas. 


\subsection{Sistemas com base em lógica fuzzy}

Dada a dificuldade na classificação visual das colônias devido à sua subjetividade, uma maneira interessante de abordar esse problema, dentre outros no campo de inteligência artificial, é utilizando-se de sistemas baseados em lógica fuzzy. A teoria de conjuntos fuzzy foi introduzida por Lotfi A. Zadeh em $1965^{158}$ e é particularmente útil quando há dificuldade de classificar se um elemento deve ou não pertencer a um determinado conjunto da lógica clássica binária. Para lidar com essa incerteza, ele criou um novo conceito denominado grau de pertinência, com o qual um elemento poderia passar a ter a possibilidade de pertencer de um dado conjunto de maneira parcial. Esse grau pode variar de zero a um, onde zero indica que o elemento não participa do grupo, um indica que o elemento participa integralmente do grupo e os valor intermediários dão a possibilidade do elemento participar parcialmente do grupo. A partir dessa teoria é possível realizar a modelagem e manipulação de informações vagas e imprecisas (da onde deriva a palavra fuzzy - do inglês nebuloso), por exemplo, através de regras linguísticas baseadas no conhecimento de especialistas. Essa teoria tem sido utilizada com sucesso na geração de modelos matemáticos que vêm sido utilizados em aplicações práticas em diversas áreas do conhecimento ${ }^{159}$, particularmente no controle de processos onde há necessidade de tomada de decisão ${ }^{160}$.

Vistas ao microscópio de contraste de fase, mesmo as colônias de células iPS murinas que não terminaram o processo de reprogramação por completo apresentam características visuais que permite-se distingui-las das células feeder com bastante facilidade. Após 20-30 dias da transdução viral, as colônias apresentam bordas que determinam seus limites, uma coloração contrastante (seja por ser mais escura ou por 
ser em tom brilhante, denominado refringente) e geralmente a impossibilidade de se identificar células individuais no interior da colônia com no aumento de 40X. É importante ressaltar que essas características são diferentes das células iPS humanas, que não foram abordadas nesse momento. Nessa tese, quando foi feita a reprogramação utilizando-se retrovírus e todas as colônias coletadas foram fotografadas. Posteriormente, observando-as com cuidado foi possível perceber de maneira subjetiva que algumas imagens estavam mais associadas às colônias que sobreviveram, e outras associadas às colônias que não sobreviveram ao processo de reprogramação. O processo de manipulação dessas células é extenuante e passou-se a cogitar a possibilidade de distinguir visualmente as colônias iPS com potencial de sobreviver e ser colônias verdadeiras das demais.

\section{Materiais, métodos e resultados.}

Existe um grande número de variáveis que poderiam ser avaliadas com o objetivo de identificar colônias visualmente, inclusive algumas relacionadas à imagem propriamente dita, que poderiam até mesmo ser usada para criar uma avaliação computacional automatizada (de maneira análoga ao reconhecimento de faces existente hoje em câmeras fotográficas). Contudo, para simplificar optou-se por uma avaliação a partir de descrição de humanos de cinco variáveis eleitas como importantes e usadas para compor um primeiro modelo fuzzy. Nesse estudo em particular, a definição de colônia verdadeira se baseou na possibilidade da colônia proliferar após ter sido coletada e por ter marcação positiva em ensaio de fosfatase alcalina, todos feitos à posteriori e devidamente anotados. Ao todo 136 imagens foram avaliadas por 18 indivíduos diferentes. Dentre eles há pessoas com diferentes 
graus de conhecimento a respeito de células e cinco especialistas (indivíduos que trabalham diretamente com esse tipo celular e têm vivência com o processo de reprogramação nuclear). Todos tiveram que responder um questionário a respeito das imagens, classificando três características da imagem possíveis de serem descritas verbalmente (os graus de definição de borda, de homogeneidade de textura e de “craquelamento"), em graus variando de 1 a 5 e comparadas a uma tábua-guia e o tamanho relativo da colônia em relação a um núcleo de fibroblasto da camada feeder presente na imagem (Figura suplementar 6). O termo craquelamento foi emprestado das artes para definir uma textura onde há pequenas rachaduras na imagem. Além disso, os especialistas foram também desafiados a classificar as imagens entre colônias verdadeiras e falsas e essa informação foi utilizada para realização de curvas ROC e análise concordância kappa. 
1- Quão bem definida é a borda da colônia?

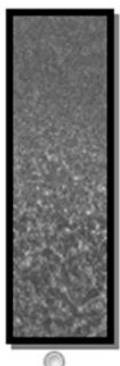

1

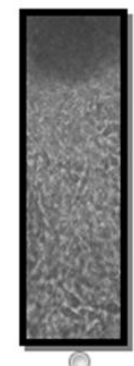

2

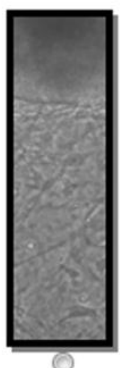

3

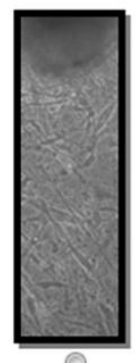

4

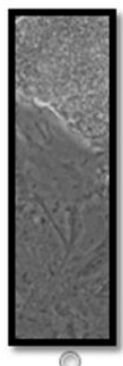

5

2- Quão homogênea é a textura da colônia?

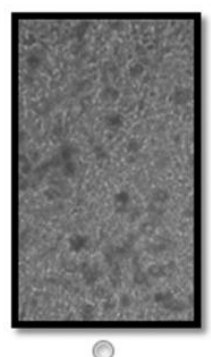

1

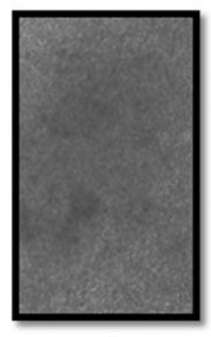

2

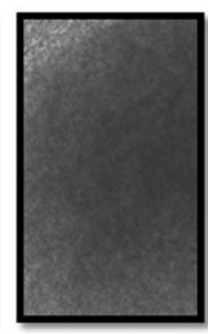

3
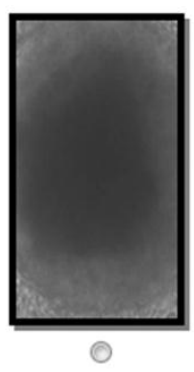

4

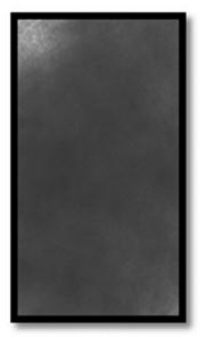

5

3- Qual é o grau de "craquelamento" da textura da colônia?

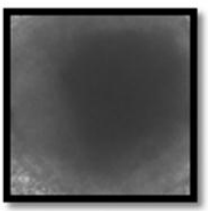

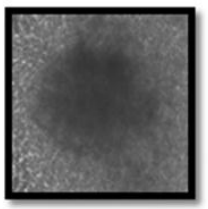

2

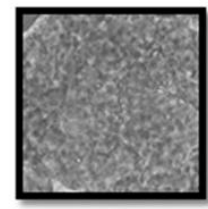

3

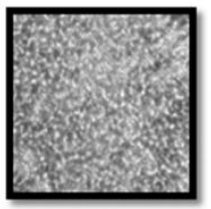

4

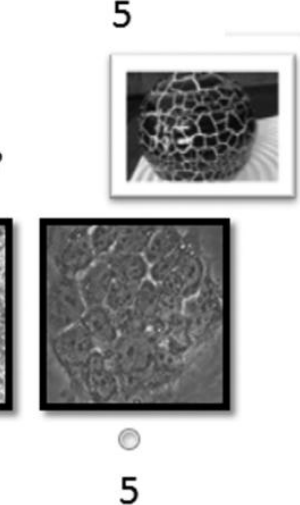

Figura suplementar 6: Imagens utilizadas como tábua-guia para classificação das 136 do banco de imagens. Caso houvesse dúvidas entre dois valores na classificação, os indivíduos foram orientados a anotar o valor mediano (ex. 3,5 quando em dúvida entre 3 ou 4)

O tamanho e tempo desde a infecção (que é determinado pelo experimento) são duas variáveis não relacionadas à imagem que são muito interessantes para se tirar informações (por exemplo, após pouco tempo de infecção, mesmo que uma colônia grande apareça, há poucas possibilidades dela ser verdadeira, pois o processo tem um tempo ótimo para acontecer). Porém, elas não foram utilizadas para compor o modelo nesse primeiro momento. 
No modelo fuzzy, as classificações variando de 1 a 5 de cada variável a respeito da imagem foram normalizadas linearmente para graus de pertinência variando de 0 a 1 , ou seja, a classificação 1 , no modelo indica 0 , a 5 indica 1 e assim sucessivamente. Foi utilizado três funções de pertinência de formato triangular para cada variável a respeito da imagem (Figura suplementar 7).

\section{Bordas e Homogeneidade}

A)

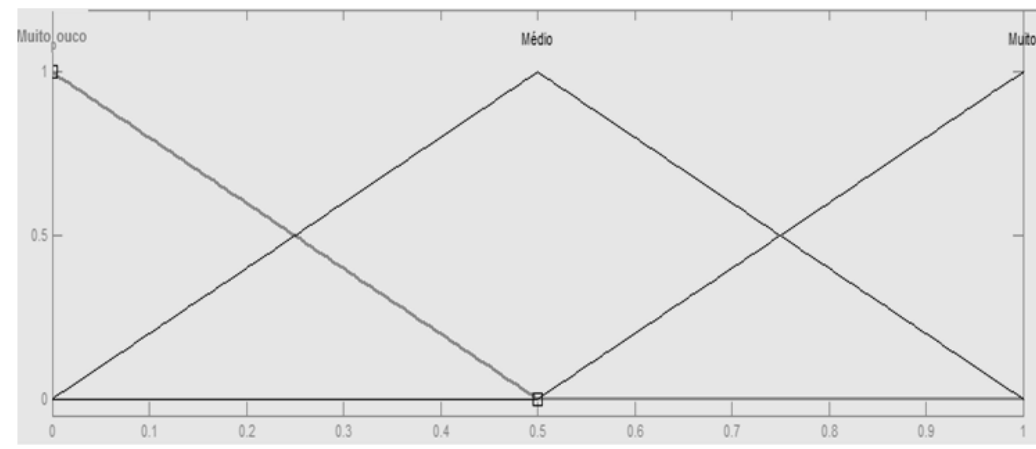

Craquelamento

B)

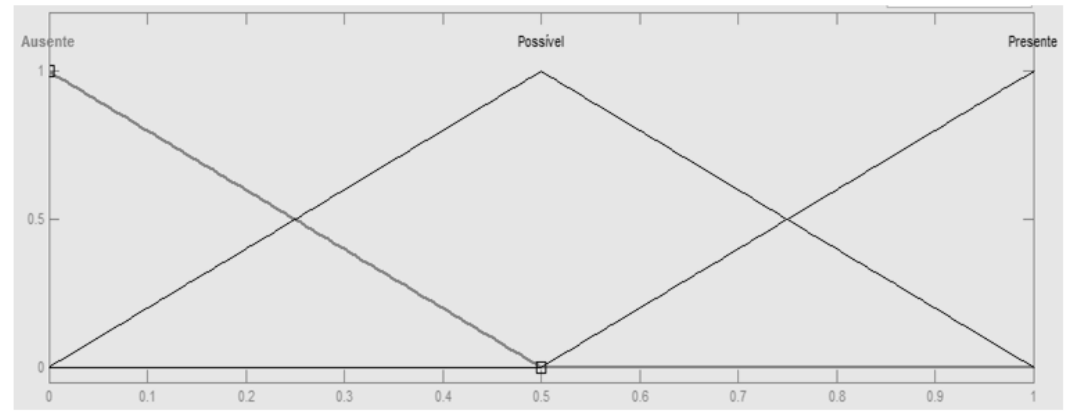

Saída do Modelo

C)

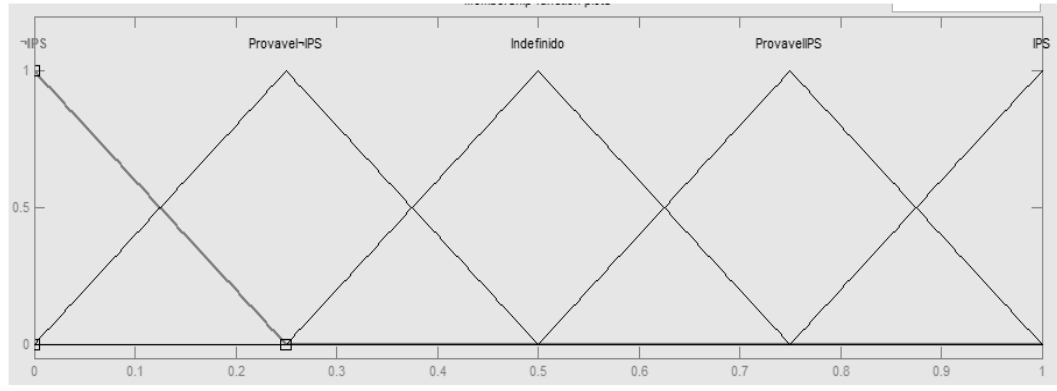

Figura suplementar 7: As classificações de grau de definição de (A) bordas e homogeneidade apresentam funções de pertinência dadas pelos predicados "Ausente" (de 0 a 0.5), "Possível" (de 0.0 a 1) e "Presente" (de 0,5 a 1) e (B) craquelamento pelos predicados "Ausente" (de 0 a 0.5), "Possível" (de 0.0 a 1) e "Presente" (de 0,5 a 1); Note que não há região descoberta nos domínios. Como saída, após a defuzzyficação $(\mathbf{C})$, tem-se que "Não é iPS", "provavelmente não é iPS", "Indefinido" "provável iPS" ou "iPS". 
Além disso, a partir dessas funções de pertinência foi criada a base de regras que compõe o modelo, a partir da qual é possível estabelecer as conexões entre as variáveis e as funções de pertinência previamente estabelecidas (Figura suplementar 8).

A)

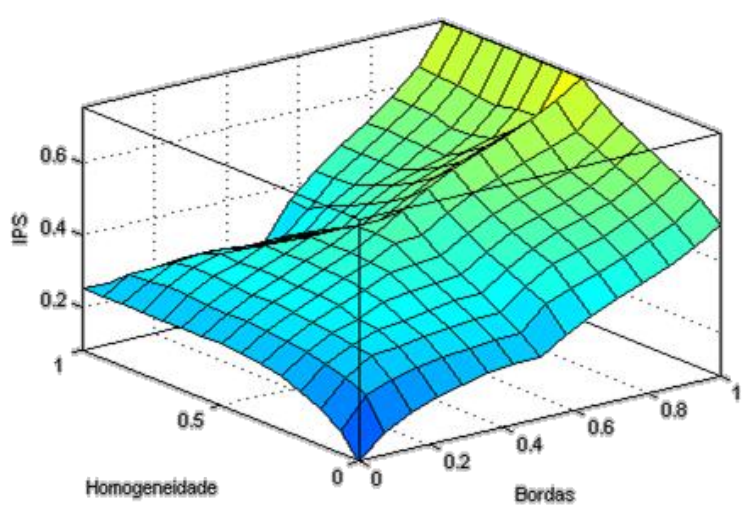

B)

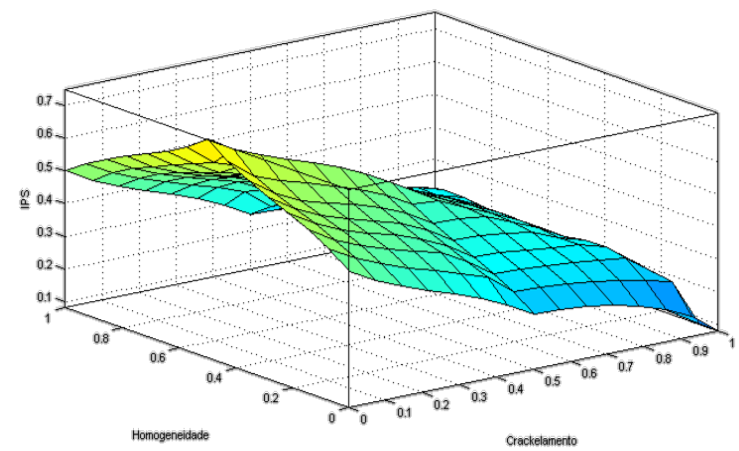

Figura suplementar 8: Superfície 3D da variação não-linear da possibilidade de ser ou não iPS em função do grau de homogeneidade, definição de bordas e craquelamento.

Como resultado preliminar, foi realizada a avaliação da concordância da classificação de verdadeiro e falso entre os cinco especialistas e o gabarito (Tabela suplementar 1). Essa medida de concordância, quando estatisticamente significativa, varia de 0 a 1 , sendo a interpretação dada pelos seguintes intervalos: 0 a 0,19 como concordância pobre; 0,20 a 0,39 concordância satisfatória; 0,40 a 0,59 como concordância moderada; 0,60 a 0,79 como concordância substancial e 0,80 a 1 como concordância quase perfeita ${ }^{161}$. 
Tabela suplementar 1: Análise de concordância Kappa entre os especialistas e o gabarito

\begin{tabular}{cccccc} 
Kappa & Gabarito & $\begin{array}{c}\text { Especialista } \\
\text { Especialista }\end{array}$ & $\begin{array}{c}\text { Especialista } \\
\text { Especialista }\end{array}$ \\
Especialista 1 & 0,664 & 0,588 & 0,315 & 0,366 & 0,511 \\
Especialista 2 & 0,486 & -- & 0,246 & 0,373 & 0,506 \\
Especialista 3 & 0,187 & -- & -- & 0,393 & 0,177 \\
Especialista 4 & 0,315 & -- & -- & -- & 0,273 \\
Especialista 5 & 0,54 & -- & -- & -- & -- \\
\hline
\end{tabular}

Como pode ser observado, em todos os casos houve concordância significativa na classificação como verdadeiro e falso. Ainda que em um dos casos (Especialista 5 vs Especialista 3) a concordância tenha sido pobre, a maior parte das vezes há concordância moderada ou substancial, inclusive com o gabarito.

Com relação à saída do modelo, procurou-se verificar a curva ROC dos especialistas e do leigo avaliado (Figura suplementar 9), bem como fazer uma verificação da correção entre eles utilizando-se o método de Spearman (Tabela suplementar 2). A curva ROC (do inglês, Receiver Operating Characteristic) é uma poderosa ferramenta que permite exprimir a relação entre verdadeiros positivos (sensibilidade) e falsos positivos (um menos especificidade). A área sobre a curva está associada com o desempenho da classificação e varia de 0,5 a 1 . Acima do índice de 0,7 é considerado como "satisfatório". Como pode ser observado, exceto para um dos especialistas e para o leigo, o desempenho foi satisfatório pela área sob a curva ROC. 

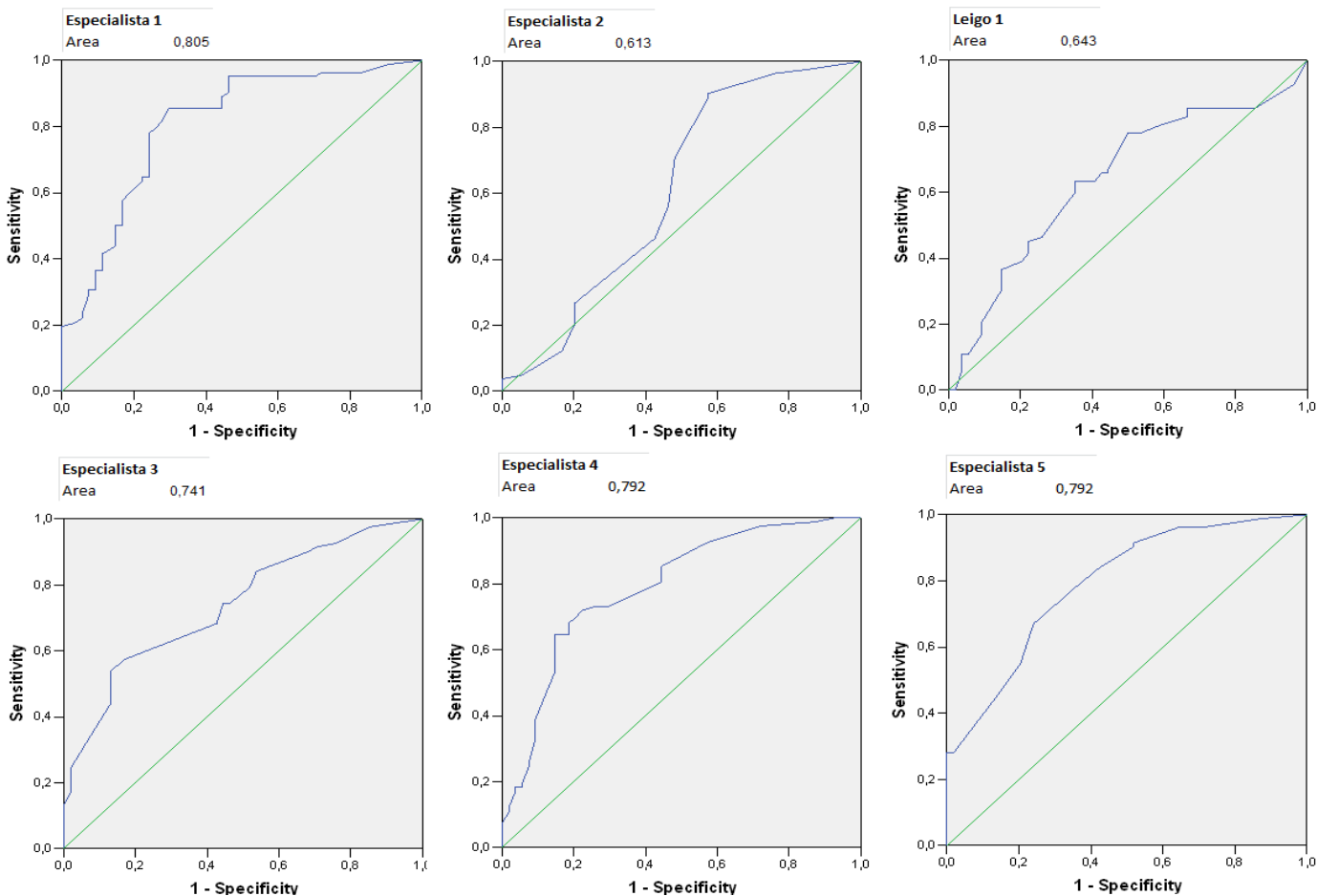

Figura suplementar 9: Curvas ROC apresentando a relação entre verdadeiros e falsos positivos na medida em que se varia o critério de decisão. A área sobre a curva também é apresentada e está associada com o desempenho da classificação. Ela varia de 0,5 a 1 e acima de 0,7 é considerado como satisfatório. Observe que a curva do leigo e do especialista 2 estão com área menor do que 0,7.

Em adição, a correlação, pelo método de Spearman, mostrou-se também significativa em todas as comparações, inclusive entre os diferentes especialistas e o leigo avaliado.

Tabela suplementar 2: Análise de correlação pelo método de Spearman. ** indica $\mathrm{p}<0,01$.

\begin{tabular}{|ccccccc|}
\hline Spearman & $\begin{array}{c}\text { Especialista } \\
1\end{array}$ & $\begin{array}{c}\text { Especialista } \\
2\end{array}$ & Leigo 1 & Especialista & $\begin{array}{c}\text { Especialista } \\
4\end{array}$ & $\begin{array}{c}\text { Especialista } \\
5\end{array}$ \\
\hline Especialista 1 & 1 & $0,603(* *)$ & $0,406(* *)$ & $0,643(* *)$ & $0,743(* *)$ & $0,741(* *)$ \\
\hline Especialista 2 & $0,603(* *)$ & 1 & $0,265(* *)$ & $0,505(* *)$ & $0,612(* *)$ & $0,611(* *)$ \\
\hline Leigo 1 & $0,406(* *)$ & $0,265(* *)$ & 1 & $0,419(* *)$ & $0,380(* *)$ & $0,386(* *)$ \\
\hline Especialista 3 & $0,643(* *)$ & $0,505(* *)$ & $0,419(* *)$ & 1 & $0,559(* *)$ & $0,657(* *)$ \\
\hline Especialista 4 & $0,743(* *)$ & $0,612(* *)$ & $0,380(* *)$ & $0,559(* *)$ & 1 & $0,720(* *)$ \\
\hline Especialista 5 & $0,741(* *)$ & $0,611(* *)$ & $0,386(* *)$ & $0,657(* *)$ & $0,720(* *)$ & 1 \\
\hline
\end{tabular}


Tomados em conjunto, esses resultados sugerem fortemente que o sistema fuzzy elaborado é capaz de auxiliar na classificação de colônias iPS murinas tendo performance igual ou superior à classificação visual direta realizada por indivíduos com experiência na identificação das colônias de iPS verdadeiras.

\section{Conclusões}

Usar a teoria de conjuntos fuzzy como ferramentas para classificar colônias de iPS murinas parece bastante eficaz. Isso é bastante interessante, pois não é raro pesquisadores desacreditando da possibilidade de se distinguir visualmente colônias falsas de verdadeiras, salvo quando há grandes diferenças morfológicas entre elas e na ausência de camada feeder. Ainda que nesse trabalho não tenha sido feita a avaliação de todos os parâmetros para definir pluripotência de uma colônia, a avaliação da fosfatase alcalina é um passo importante e realizado por praticamente todos os laboratórios.

Essa nova abordagem pode ser de grande utilidade para pelo menos dois objetivos: redução de custos e de esforço no processo de coleta de colônias. Isso pode ser de grande valia em situações onde é necessário trabalhar com células sem modificações gênicas com produção em larga escala. Além disso, essa abordagem pode ser adaptada para ser empregada para o treinamento de pessoal de laboratório a visualizar as colônias corretas.

\section{Referências}

As estão contidas na lista de referências principal. 
Apêndice IV - Padronização do ELISA para detecção de fatores nucleares utilizando anticorpos comerciais.

Uma vez que os fatores de transcrição que foram desenvolvidos nessa tese não apresentam um tag para permitir o reconhecimento por anticorpos padrão (como myc ou HA) foi necessário se estabelecer a faixa de detecção de cada um deles em ensaios de ELISA, específicos para cada proteína. A não-inclusão dos tags foi proposital, para evitar que a proteína tivesse um tamanho ainda maior (que poderia interferir na possibilidade de entrada nas células) e ainda para evitar a possbilidade de que os tags interferissem na atividade funcional dos fatores de transcrição.

Começou-se com um teste onde fez-se ensaios com a combinação de proteína recombinante à $400 \mathrm{ng} / \mathrm{mL}, 4 \mathrm{ng} / \mathrm{mL}$ ou $0 \mathrm{ng} / \mathrm{mL}$ (e meio de cultura condicionado, como teste) com o anticorpo de captura na concentração de $1 \mu \mathrm{g} / \mathrm{mL}$ ou $0,5 \mu \mathrm{g} / \mathrm{mL}$ e de anticorpo detecção nas concentrações $0,1 \mu \mathrm{g} / \mathrm{mL}$ e $0,05 \mu \mathrm{g} / \mathrm{mL}$ (Figura suplementar 10). Procurou-se escolher a combinação que oferecesse o maior sinal (preferencialmente no ponto de $400 \mu \mathrm{g} / \mathrm{mL}$ ), com o menor ruído (no ponto de 0 $\mu \mathrm{g} / \mathrm{mL})$. 


\section{OCT3/4}

\begin{tabular}{|c|c|c|c|c|c|c|c|}
\hline \multirow{5}{*}{$\begin{array}{l}\text { Primário } \\
0,5 \mathrm{ug} / \mathrm{ml}\end{array}$} & \multicolumn{2}{|c|}{$\begin{array}{l}\text { Secundário 0,05 } \\
\mathrm{ug} / \mathrm{ml}\end{array}$} & \multirow{2}{*}{$\frac{\text { Media }}{0,238}$} & \multicolumn{2}{|c|}{ Secundário 0,1 ug/ml } & \multirow{2}{*}{$\begin{array}{c}\text { Media } \\
0,345\end{array}$} & \\
\hline & 0,246 & 0,230 & & 0,339 & 0,351 & & \multirow{4}{*}{$\begin{array}{r}400 \mathrm{pg} / \mathrm{u} \\
40 \mathrm{pg} / \mathrm{u} \\
\text { meio }\end{array}$} \\
\hline & 0,062 & 0,058 & 0,060 & 0,074 & 0,073 & 0,073 & \\
\hline & 0,058 & 0,056 & 0,057 & 0,070 & 0,071 & 0,070 & \\
\hline & 0,145 & 0,142 & 0,144 & 0,222 & 0,218 & 0,220 & \\
\hline \multirow{4}{*}{$\begin{array}{l}\text { Primário } \\
1 \mathrm{ug} / \mathrm{ml}\end{array}$} & 0,338 & 0,332 & 0,335 & 0,484 & 0,465 & 0,474 & $400 \mathrm{pg} / \mathrm{ul}$ \\
\hline & 0,067 & 0,065 & 0,066 & 0,084 & 0,082 & 0,083 & $40 \mathrm{pg} / \mathrm{ul}$ \\
\hline & 0,066 & 0,066 & 0,066 & 0,081 & 0,082 & 0,081 & 0 \\
\hline & 0,270 & 0,268 & 0,269 & 0,423 & 0,429 & 0,426 & meio \\
\hline
\end{tabular}

SOX2

\begin{tabular}{|c|c|c|c|c|c|c|c|}
\hline & \multicolumn{2}{|c|}{ Secundário $0,2 \mathrm{ug} / \mathrm{ml}$} & \multirow{2}{*}{$\frac{\text { Media }}{0,1825}$} & \multicolumn{2}{|c|}{ Secun dário $0,1 \mathrm{ug} / \mathrm{ml}$} & Media & \multirow{5}{*}{$\begin{array}{r}400 \mathrm{pg} / \mathrm{ul} \\
40 \mathrm{pg} / \mathrm{ul} \\
\text { meio } \\
0\end{array}$} \\
\hline Primário & 0,1878 & 0,1772 & & 0,117 & 0,1511 & 0,1341 & \\
\hline \multirow[t]{3}{*}{$1 \mathrm{ug} / \mathrm{ml}$} & 0,1391 & 0,1398 & 0,1395 & 0,1026 & 0,1113 & 0,1070 & \\
\hline & 0,1185 & 0,1167 & 0,1176 & 0,0847 & 0,1147 & 0,0997 & \\
\hline & 0,1334 & 0,1407 & 0,1371 & 0,0895 & 0,1075 & 0,0985 & \\
\hline Primário & 0,1175 & 0,1243 & 0,1209 & 0,0932 & 0,1161 & 0,1047 & $400 \mathrm{pg} / \mathrm{ul}$ \\
\hline \multirow[t]{3}{*}{$0,5 u g / m l$} & 0,101 & 0,1041 & 0,1026 & 0,0715 & 0,0793 & 0,0754 & $40 \mathrm{pg} / \mathrm{ul}$ \\
\hline & 0,0902 & 0,0857 & 0,0880 & 0,0742 & 0,0849 & 0,0796 & meio \\
\hline & 0,098 & 0,0945 & 0,0963 & 0,0901 & 0,0907 & 0,0904 & 0 \\
\hline
\end{tabular}

\section{KLF4}

\begin{tabular}{|c|c|c|c|c|c|c|c|}
\hline \multirow{3}{*}{$\begin{array}{l} \\
\text { Primário } \\
0,5 u g / m l\end{array}$} & \multicolumn{2}{|c|}{$\begin{array}{l}\text { Secundário 0,05 } \\
\mathrm{ug} / \mathrm{ml}\end{array}$} & \multirow{2}{*}{$\begin{array}{c}\text { Media } \\
0,158\end{array}$} & \multicolumn{2}{|c|}{ Secundário $0,1 \mathrm{ug} / \mathrm{ml}$} & \multirow{2}{*}{$\frac{\text { Media }}{0,257}$} & \\
\hline & 0,152 & 0,164 & & 0,312 & 0,202 & & \multirow{4}{*}{$\begin{array}{r}400 \mathrm{pg} / \mathrm{ul} \\
40 \mathrm{pg} / \mathrm{ul} \\
0 \\
\text { meio }\end{array}$} \\
\hline & 0,046 & 0,045 & 0,045 & 0,053 & 0,058 & 0,055 & \\
\hline & 0,047 & 0,044 & 0,046 & 0,051 & 0,053 & 0,052 & \\
\hline & 0,041 & 0,043 & 0,042 & 0,048 & 0,051 & 0,049 & \\
\hline \multirow{4}{*}{$\begin{array}{l}\text { Primário } \\
1 \mathrm{ug} / \mathrm{ml}\end{array}$} & 0,180 & 0,179 & 0,179 & 0,249 & 0,457 & 0,353 & \multirow{4}{*}{$\begin{array}{r}400 \mathrm{pg} / \mathrm{ul} \\
40 \mathrm{pg} / \mathrm{ul} \\
0 \\
\text { meio }\end{array}$} \\
\hline & 0,049 & 0,049 & 0,049 & 0,055 & 0,060 & 0,058 & \\
\hline & 0,045 & 0,046 & 0,045 & 0,054 & 0,057 & 0,056 & \\
\hline & 0,054 & 0,048 & 0,051 & 0,054 & 0,052 & 0,053 & \\
\hline
\end{tabular}

\section{c-MYC}

\begin{tabular}{|c|cc|c|cc|c|r|}
\cline { 2 - 8 } \multicolumn{1}{c|}{} & Secundário $0,05 \mathrm{ug} / \mathrm{ml}$ & Media & \multicolumn{2}{l|}{ Secundário 0,1 ug/ml } & Media & \\
\hline Primário & 0,323 & 0,318 & $\mathbf{0 , 3 2 1}$ & 0,439 & 0,480 & $\mathbf{0 , 4 5 9}$ & $400 \mathrm{pg} / \mathrm{ul}$ \\
$\mathbf{0 , 5 u g / m l}$ & 0,082 & 0,078 & $\mathbf{0 , 0 8 0}$ & 0,116 & 0,120 & $\mathbf{0 , 1 1 8}$ & $40 \mathrm{pg} / \mathrm{ul}$ \\
& 0,081 & 0,074 & $\mathbf{0 , 0 7 7}$ & 0,112 & 0,111 & $\mathbf{0 , 1 1 2}$ & 0 \\
& 0,065 & 0,067 & $\mathbf{0 , 0 6 6}$ & 0,090 & 0,094 & $\mathbf{0 , 0 9 2}$ & meio \\
\hline Primário & 0,502 & 0,484 & $\mathbf{0 , 4 9 3}$ & 0,669 & 0,660 & 0,665 & $400 \mathrm{pg} / \mathrm{ul}$ \\
1ug/ml & 0,109 & 0,108 & $\mathbf{0 , 1 0 9}$ & 0,166 & 0,162 & 0,164 & $40 \mathrm{pg} / \mathrm{ul}$ \\
& 0,108 & 0,103 & $\mathbf{0 , 1 0 6}$ & 0,163 & 0,166 & 0,165 & 0 \\
& 0,102 & 0,096 & $\mathbf{0 , 0 9 9}$ & 0,136 & 0,134 & 0,135 & meio \\
\hline
\end{tabular}

Figura suplementar 10: Ensaio de padronização da faixa de detecção de cada sistema de ELISA.

Em vermelho está destacada a combinação escolhida para os ensaios posteriores. Nesse experimento, a detecção de SOX2 não foi possível, mas nos posteriores foi trocado o meio de teste e foi possível.

Na sequência, procedeu-se com a verificação da possibilidade de detecção da proteína secretada no meio sobrenadante das linhagens produtoras 293A-TATк-

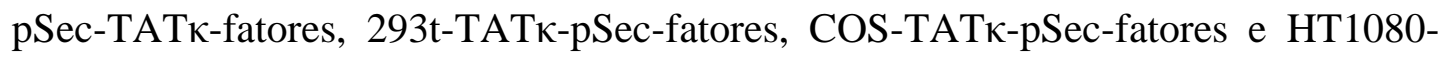


TATк-pSec-fatores. Num primeiro momento, não se preocupou em estabelecer condições padronizadas para a produção. Apenas verificar se era possível detectar algo no meio de cultura e se confirmar se a distribuição dos pontos da curva padrão seguia o padrão linear, que era o esperado. Além disso, foi incluído um ponto máximo de 800ng/mL no ELISA, para aumentar a amplitude da detecção.

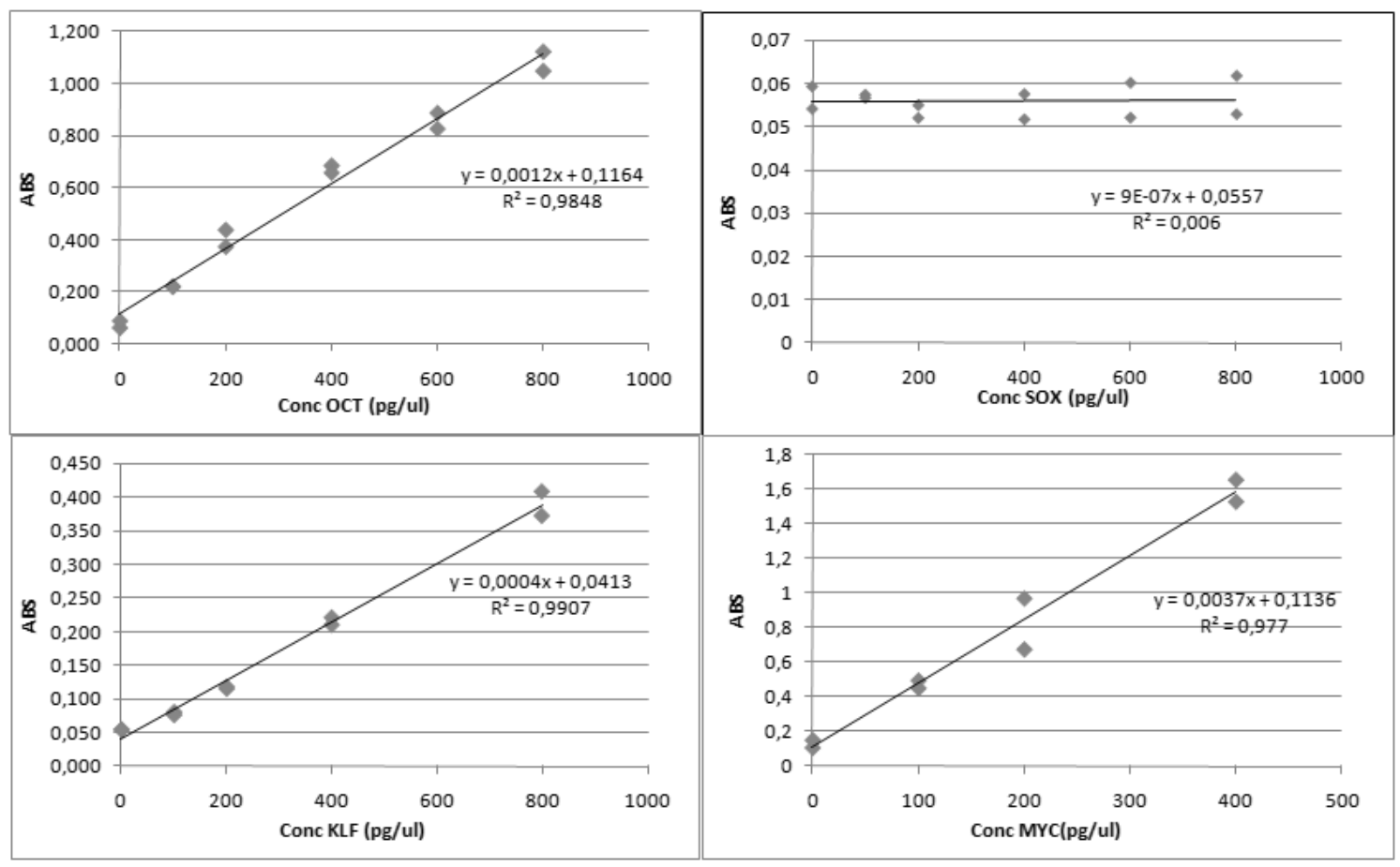

Figura suplementar 11: Curvas padrão dos ensaios de ELISA para OCT, SOX, KLF e MYC.

É possível observar o ajuste linear dos experimentos, exceto para SOX2, que não apresenta sinal significativo.

Como pode ser constatado, a curva padrão de SOX2 não funcionou, possivelmente devido a algum problema na proteína recombinante (mais abaixo é possível observar que há detecção nas amostras). Neste momento, apenas a título de comparação, foi utilizada a equação de reta da proteína OCT3/4 para os dados de detecção de SOX no sobrenadante. Um novo tubo de SOX2 foi adquirido e repetido o ensaio de quantificação dessa proteína (dados não mostrados). 
Seguem na tabela suplementar $\mathbf{3}$ abaixo as concentrações obtidas das amostras.

Tabela suplementar 3: Quantificação dos fatores de transcrição no meio de cultura.

Foi possível detectar proteína em todos, exceto no meio condicionado da proteína MYC. * indica leitura abaixo do mínimo detectável.

\begin{tabular}{lccccc}
\hline \multicolumn{1}{c}{ Linhagem } & \multicolumn{2}{c}{ Média } & \multicolumn{2}{c}{ Erro } \\
OCT3/4 & & & & \multicolumn{2}{c}{} \\
$293 \mathrm{t}$ & TK-OCT & 47,8 & $\mathrm{pg} / \mathrm{uL}$ & 1,8 & $\mathrm{pg} / \mathrm{uL}$ \\
$293 \mathrm{~A}$ & TK-OCT & 235,4 & $\mathrm{pg} / \mathrm{uL}$ & 8,8 & $\mathrm{pg} / \mathrm{uL}$ \\
COS-7 & TK-OCT & $*$ & $\mathrm{pg} / \mathrm{uL}$ & $*$ & $\mathrm{pg} / \mathrm{uL}$ \\
HT1080 & TK-OCT & $*$ & $\mathrm{pg} / \mathrm{uL}$ & $*$ & $\mathrm{pg} / \mathrm{uL}$ \\
SOX2 & & & & & \\
293t & TK-SOX & 164,4 & $\mathrm{pg} / \mathrm{uL}$ & 2,1 & $\mathrm{pg} / \mathrm{uL}$ \\
293A & TK-SOX & 144,9 & $\mathrm{pg} / \mathrm{uL}$ & 8,5 & $\mathrm{pg} / \mathrm{uL}$ \\
COS-7 & TK-SOX & $*$ & $\mathrm{pg} / \mathrm{uL}$ & $*$ & $\mathrm{pg} / \mathrm{uL}$ \\
HT1080 & TK-SOX & $*$ & $\mathrm{pg} / \mathrm{uL}$ & $*$ & $\mathrm{pg} / \mathrm{uL}$ \\
KLF4 & & & & & \\
$293 \mathrm{t}$ & TK-KLF & 218,3 & $\mathrm{pg} / \mathrm{uL}$ & 13,5 & $\mathrm{pg} / \mathrm{uL}$ \\
293A & TK-KLF & 4749,3 & $\mathrm{pg} / \mathrm{uL}$ & 105,7 & $\mathrm{pg} / \mathrm{uL}$ \\
COS-7 & TK-KLF & 287,2 & $\mathrm{pg} / \mathrm{uL}$ & 8,7 & $\mathrm{pg} / \mathrm{uL}$ \\
HT1080 & TK-KLF & 423,8 & $\mathrm{pg} / \mathrm{uL}$ & 10,3 & $\mathrm{pg} / \mathrm{uL}$ \\
c-MYC & & & & & \\
$293 \mathrm{t}$ & TK-MYC & $*$ & $\mathrm{pg} / \mathrm{uL}$ & $*$ & $\mathrm{pg} / \mathrm{uL}$ \\
293A & TK-MYC & $*$ & $\mathrm{pg} / \mathrm{uL}$ & $*$ & $\mathrm{pg} / \mathrm{uL}$ \\
COS-7 & TK-MYC & $*$ & $\mathrm{pg} / \mathrm{uL}$ & $*$ & $\mathrm{pg} / \mathrm{uL}$ \\
HT1080 & TK-MYC & $*$ & $\mathrm{pg} / \mathrm{uL}$ & $*$ & $\mathrm{pg} / \mathrm{uL}$ \\
\hline
\end{tabular}

Com o intuito de uniformizar a comparação, foram estabelecidas condições padronizadas de cultura para o próximo ensaio. Estabeleceu-se que a produção seria feita em uma placa de 24 poços, na densidade celular de $10 \times 10^{4}$ células $/ \mathrm{cm}^{2}$. Outra pergunta importante seria verificar se haveria influência do tipo de meio utilizado, uma vez que as células de linhagem estão acostumadas com meio DMEM suplementado com $10 \%$ FBS ou $10 \%$ BCS e deveriam passar a ser cultivadas em meio de iPS, quando fossem ser utilizadas no sistema de reprogramação.

Fez-se, portanto, um primeiro ensaio com as linhagens produtoras de TATкOCT para identificar, além de qual seria a melhor produtora dentre os vários tipos de linhagens, qual seria o melhor meio para secreção (Tabela suplementar 4). 
Tabela suplementar 4: Quantificação do fator de transcrição OCT3/4 no meio de cultura em condições de cultivo padronizadas

(placa de 24 poços, na densidade celular de $10 \times 10^{4}$ células $/ \mathrm{cm}^{2}$ ) por tipo de meio. * indica leitura abaixo do mínimo detectável.

\begin{tabular}{|c|c|c|c|c|c|}
\hline Linhagem & Meio & \multicolumn{2}{|c|}{ Média } & \multicolumn{2}{|c|}{ Erro } \\
\hline 293t ТАТк-ОСТ & Dmem 0\%. & 55,4 & $\mathrm{pg} / \mathrm{uL}$ & 0,5 & $\mathrm{pg} / \mathrm{uL}$ \\
\hline 293t ТАТк-ОСТ & Dmem 10\% & 53,1 & $\mathrm{pg} / \mathrm{uL}$ & 1,4 & $\mathrm{pg} / \mathrm{uL}$ \\
\hline 293t ТАТк-ОСТ & Meio iPS & 52,7 & $\mathrm{pg} / \mathrm{uL}$ & 1,1 & $\mathrm{pg} / \mathrm{uL}$ \\
\hline 293А ТАТк-ОСТ & Dmem 0\%. & 173,2 & $\mathrm{pg} / \mathrm{uL}$ & 4,7 & $\mathrm{pg} / \mathrm{uL}$ \\
\hline 293А ТАТк-ОСТ & Dmem $10 \%$ & 233,6 & $\mathrm{pg} / \mathrm{uL}$ & 20,2 & $\mathrm{pg} / \mathrm{uL}$ \\
\hline 293А ТАТк-ОСТ & Meio iPS & 218,7 & $\mathrm{pg} / \mathrm{uL}$ & 14,2 & $\mathrm{pg} / \mathrm{uL}$ \\
\hline COS-7 TAТк-ОСТ & Dmem 0\%. & $*$ & $\mathrm{pg} / \mathrm{uL}$ & $*$ & $\mathrm{pg} / \mathrm{uL}$ \\
\hline COS-7 TAТк-ОСТ & Dmem $10 \%$ & $*$ & $\mathrm{pg} / \mathrm{uL}$ & $*$ & $\mathrm{pg} / \mathrm{uL}$ \\
\hline COS-7 TAТк-OCT & Meio iPS & $*$ & $\mathrm{pg} / \mathrm{uL}$ & $*$ & $\mathrm{pg} / \mathrm{uL}$ \\
\hline НТ1080 ТАТк-ОСТ & Dmem 0\%. & $*$ & $\mathrm{pg} / \mathrm{uL}$ & $*$ & $\mathrm{pg} / \mathrm{uL}$ \\
\hline НТ1080 ТАТк-ОСТ & Dmem 10\% & $*$ & $\mathrm{pg} / \mathrm{uL}$ & $*$ & $\mathrm{pg} / \mathrm{uL}$ \\
\hline НТ1080 ТАТк-ОСТ & Meio iPS & $*$ & $\mathrm{pg} / \mathrm{uL}$ & $*$ & $\mathrm{pg} / \mathrm{uL}$ \\
\hline NIH-psec TATк-ОCT & Dmem 0\%. & 53,0 & $\mathrm{pg} / \mathrm{uL}$ & 0,4 & $\mathrm{pg} / \mathrm{uL}$ \\
\hline NIH-psec TATк-ОCT & Dmem $10 \%$ & 66,3 & $\mathrm{pg} / \mathrm{uL}$ & 5,0 & $\mathrm{pg} / \mathrm{uL}$ \\
\hline NIH-psec TATк-OCT & Meio iPS & 66,5 & $\mathrm{pg} / \mathrm{uL}$ & 5,5 & $\mathrm{pg} / \mathrm{uL}$ \\
\hline NIH-Virus TATк-OCT & Dmem 0\%. & $*$ & $\mathrm{pg} / \mathrm{uL}$ & $*$ & $\mathrm{pg} / \mathrm{uL}$ \\
\hline NIH-Virus TATк-OCT & Dmem 10\% & $*$ & $\mathrm{pg} / \mathrm{uL}$ & $*$ & $\mathrm{pg} / \mathrm{uL}$ \\
\hline NIH-Virus TATк-OCT & Meio iPS & $*$ & $\mathrm{pg} / \mathrm{uL}$ & $*$ & $\mathrm{pg} / \mathrm{uL}$ \\
\hline 293t CONTROLE & Dmem 0\% & $*$ & $\mathrm{pg} / \mathrm{uL}$ & $*$ & $\mathrm{pg} / \mathrm{uL}$ \\
\hline 293A CONTROLE & Dmem 0\% & $*$ & $\mathrm{pg} / \mathrm{uL}$ & $*$ & $\mathrm{pg} / \mathrm{uL}$ \\
\hline HT1080 CONTROLE & Dmem 0\% & $*$ & $\mathrm{pg} / \mathrm{uL}$ & $*$ & $\mathrm{pg} / \mathrm{uL}$ \\
\hline NIH CONTROLE & Dmem 0\% & $*$ & $\mathrm{pg} / \mathrm{uL}$ & $*$ & $\mathrm{pg} / \mathrm{uL}$ \\
\hline 293t CONTROLE & Dmem $10 \%$ & $*$ & $\mathrm{pg} / \mathrm{uL}$ & $*$ & $\mathrm{pg} / \mathrm{uL}$ \\
\hline 293A CONTROLE & Dmem $10 \%$ & $*$ & $\mathrm{pg} / \mathrm{uL}$ & $*$ & $\mathrm{pg} / \mathrm{uL}$ \\
\hline
\end{tabular}

Como pode ser observado, não há diferenças significativas entre os tipos de meio utilizados para a produção. Além disso, destaca-se aqui a taxa de produção das células 293A, que apresentaram uma concentração no meio de cultura cerca de 4 vezes maior do que o $2^{\circ}$ colocado, 293t. É importante destacar também que as células controle (linhagens não transfectadas) não apresentam detecção em seus meios de cultura, mantido nas mesmas condições padronizadas.

Na sequência, foram avaliadas as outras proteínas, SOX, KLF e MYC. Juntos esses resultados mostram que o sistema de detecção ELISA sanduiche padronizado pelo laboratório está funcionando corretamente e que foi possível descobrir a 
concentração de cada uma das 4 proteínas recombinantes no meio de cultura de cada um dos tipos celulares candidatos a produtor de fator. Depois dessas padronizações, foi possível se determinar a concentração de produção de cada um dos quatro fatores de transcrição em cada uma das linhagens obtidas (Tabela 3). 